\title{
Sobre atravessamentos
}

\section{ARTE, CIDADE E A PRODUÇÃO DO ESPAÇO A PARTIR}

DA OBRA DE RUBENS MANO I VOL. 1

\section{TATIANA SAMPAIO FERRAZ}

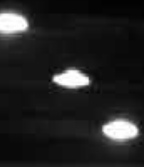




\section{SOBRE ATRAVESSAMENTOS:}

ARTE, CIDADE E A PRODUC̣ÃO DO ESPAC̣O A PARTIR DA OBRA DE RUBENS MANO

Tese apresentada ao Programa de Pós-Graduação da Faculdade de Arquitetura e Urbanismo da Universidade de São Paulo para obtenção do título de Doutora em Arquitetura e Urbanismo

Área de concentração: História e Fundamentos da Arquitetura e do Urbanismo

Orientadora: Profa. Dra. Ana Maria de Moraes Belluzzo

Exemplar revisado e alterado em relação à versão original, sob responsabilidade da autora e anuência da orientadora. A versão original, em formato digital, ficará arquivada na Biblioteca da Faculdade.

São Paulo, 27 de junho de 2018 
Autorizo a reprodução e divulgação total ou parcial deste

A

para fins de estudo e pesquisa, desde que eitadrônico,

Catalogação na Publicação | Serviço Técnico de Biblioteca

Faculdade de Arquitetura e Urbanismo da Universidade de São Paulo

\section{Ferraz, Tatiana Sampaio}

Sobre atravessamentos: arte, cidade e a produção do espaço

a partir da obra de Rubens Mano / Tatiana Sampaio Ferraz;

orientadora Ana Maria de Moraes Belluzzo.

São Paulo, 2018 | 2 v.

Tese (Doutorado) - Faculdade de Arquitetura e Urbanismo

da Universidade de São Paulo. Área de concentração: História

e Fundamentos da Arquitetura e do Urbanismo

1. Mano, Rubens. 2. Arte Contemporânea. 3. Produção do Espaço. . Arte o Cidade. 5. Experincia Urbana. Lelluzzo, Ana Maria de Moraes, orient. II. Título. 


\section{AGRADECIMENTOS}

A conclusão desta tese certamente representa um dos grandes desafios vivenciados por mim até aqui. Ela só foi possível graças ao compartilhamento, à generosidade e à colaboração de diversas pessoas e instituições ao longo dos quatro anos de pesquisa.

A decisão de ingressar nesta jornada contou de início com o encorajamento da minha família - Marco, Olivia, Marcia e Miguel -, a quem agradeço enormemente. Durante esses anos, eles me aturaram com a devida paciência e sobreviveram ao meu isolamento nos momentos imersivos necessários para o estudo. Agradeço especialmente ao meu marido, Marco, que na minha ausência educou e cuidou de Olivia com amor.

Devo dizer que sou extremamente grata à minha orientadora, profa. Ana Maria Belluzzo, que acolheu com entusiasmo meu projeto de pesquisa. Os encontros com ela foram fundamentais para a organização de minhas inquietações iniciais e para a formulação das questões, dali decantadas, que estruturam a tese. No desenvolvimento do projeto, além de suas orientações colocarem minhas ideias "no lugar", elas representaram uma rica descoberta sobre o quão potente pode ser o estudo de uma única obra de arte. Agradeço-a especialmente pela paciência com minhas indefinições e ausências no processo e pela dedicação dispensada na aceleração final. A convivência intelectual com a profa. Ana confirmou a possibilidade de que o rigor pode vir acompanhado do afeto (o que certamente levarei adiante com meus alunos).

Não poderia deixar de agradecer ao Departamento de Pós-Graduação da FAU-USP, a secretárias e secretários, especialmente na figura da Isa, que sempre me atendeu sorridente na Maranhão, e do André, que acompanhou meus primeiros anos como bolsista, nos quais esteve atento às minhas dúvidas e necessidades como discente. Agradeço igualmente à Capes pela oportunidade de realizar a pesquisa com o auxílio de bolsa até meados de 2016, quando então tive de abdicar da bolsa para tomar posse como docente na Universidade $\mathrm{Fe}$ deral de Uberlândia. Ainda dentro do espectro universitário, é preciso agradecer aos meus colegas de departamento do Curso de Artes Visuais da UFU, que se 
mostraram extremamente compreensivos comigo (apesar do pouco tempo de convívio), permitindo minha licença em agosto de 2017 para que eu pudesse me dedicar à conclusão da tese.

Desde o começo da pesquisa, pude compartilhar ideias, obras e inquietações com o artista Rubens Mano, mesmo ainda sem saber ao certo qual seria o destino final da tese. A ele agradeço imensamente por ter dispensado horas de conversa sobre o trabalho, fosse num encontro informal regado a café ou cerveja num bar qualquer da Vila, ou formalmente, em duas entrevistas realizadas em seu ateliê em 2015. Além de admirar sua obra, nos últimos anos Rubens tornou-se um importante interlocutor para mim no mundo das artes, com o qual tenho partilhado conversas sobre arte, cidade, política e tudo o mais que a experiência paulistana desperta. Quero agradecê-lo por fim pelas imagens inéditas cedidas gentilmente para esta tese.

Agradeço aos professores Lorenzo Mammì e Agnaldo Farias pelas considerações agregadoras durante a banca de qualificação.

Agradeço aos bibliotecários que me ajudaram pacientemente com as buscas e acessos a um conjunto extensivo de publicações consultadas, especialmente aos funcionários das bibliotecas da ECA-USP e da FAU-USP.

Agradeço à amiga mais que querida Raquel Garbelotti, que sempre me deu força e estímulo para ingressar no doutorado e para a vida acadêmica, de modo geral.

Agradeço a duas queridas interlocutoras, solidárias às minhas inquietações no processo da escrita: à minha professora Marta Lagreca, que trouxe uma leitura precisa sobre o trabalho no momento em que as estruturas estavam sendo erguidas para o assentamento final; e à amiga Carolina Soares, que acompanhou de perto minhas angústias, com atenção e carinho, dispondo-se a ler parte dos meus escritos em andamento.

Agradeço aos demais artistas que gentilmente cederam as imagens reproduzidas na tese: Ana Maria Tavares, Caio Reisewitz, Carla Zaccagnini, Clarissa Tossin, Laura Vinci, Regina Silveira. Ao Museu de Arte Contemporânea da USP, nas figuras de Cristina Freire e Marília Lopes, por ceder imagens das obras de Julio Plaza do acervo, bem como à Ana Bela Plaza por autorizar a reprodução das mesmas.
Agradeço à revisora Rafaela Cera pela atenção dispensada nas leituras do texto, bem como à Luciana Facchini pela generosidade em tornar a leitura do trabalho acadêmico visualmente agradável aos futuros leitores.

Por fim, quero agradecer às amigas que admiro, Taisa Palhares, Úrsula Peres e Silvana Nascimento, que acompanharam esta empreitada, com maior ou menor proximidade. Como mulheres que desafiam a rotina materna para enfrentar 0 trabalho acadêmico com entusiasmo e precisão, elas me encorajaram a cada titubeio no percurso da tese. 
A experiência de viver em São Paulo certamente foi o principal motor que mobilizou esta tese. Dentre as cidades brasileiras, a capital paulista é a que expressa de forma mais intensa e emblemática as contradições de um país que buscou lançar-se ao futuro, mas que teve seu "espírito moderno" constantemente posto à prova diante das dificuldades de construção de uma esfera pública na periferia do capital. Desde sua fundação, a cidade foi movida pelo binômio demolição-construção, passou pela edificação do principal parque industrial nacional, transformou-se paulatinamente em cidade de serviços, e nos anos 1990 somou-se às cidades globais. Desde então, a vida urbana paulistana vem enfrentando duas situações: a que é fruto da herança moderna, vivenciada em sua incompletude e fragmentação, e a da cidade contemporânea e suas novas dinâmicas virtualizadas. Nesse panorama, a década de 1990 marcou uma mudança estrutural tanto nos modos de vida da cidade como nas práticas artísticas, que buscam responder à nova condição urbana, cujo movimento corresponde ao crescente interesse de parte dos artistas pela cidade. Diante disso, a tese buscou examinar como, a partir dos anos 1990, a experiência paulistana se diferencia de contextos históricos anteriores, donde já se verificava uma aproximação entre os dois mundos. Para tanto, elegeu-se como objeto de estudo um conjunto de obras de Rubens Mano, tomado como modelar dos pressupostos teóricos sobre as transformações urbanas verificadas no período. O estudo dessas obras salientou dois aspectos fundamentais em sua trajetória: a revisão crítica do projeto moderno - e a produção de espaço dali decorrente -, e uma nova perspectiva crítica e contextualista da arte contemporânea sobre a vida urbana, que tensiona a obra na direção de um híbrido capaz de transitar entre os mundos artístico e extra-artístico. Ao lado de outros artistas, Mano vêm demostrando que o fazer artístico está cada vez mais imbricado à experiência do cotidiano, atento estética e politicamente à problemática urbana e suas contradições.

PALAVRAS-CHAVE: Rubens Mano; arte contemporânea; arte e cidade; vida urbana. 
ABSTRACT

The experience of living in São Paulo certainly was the main engine that mobilized this thesis. Among the Brazilian cities, the capital of São Paulo is the one that expresses in a more intense and emblematic way the contradictions of a country that sought to launch itself into the future, but whose "modern spirit" was constantly put to the test in front of the difficulties of building a public sphere on the periphery of capital. Since its foundation the city has been moving by the binomial demolition-construction, passed by the construction of the main national industrial park, gradually replaced in a tertiary city that in the 1990's were added to the global cities. Since then, the São Paulo urban life has been facing two situations: that of modern inheritance, experienced in its incompleteness and fragmentation, and that of the contemporary city and its new virtualized dynamics. In this panorama, the 1990's marked a structural change both in the ways of life in the cities and in artistic practices, which have been responding to the new urban condition, which movement corresponds to the raise of art interests to the city. In view of this, this thesis sought to examine how the São Paulo experience from the 1990's differs from previous historical contexts, where there was already an approximation between art and city. For this, the thesis choses as object of study a set of works by Rubens Mano, taken as a modeling of the theoretical assumptions about the urban transformations verified among that period. The study of these works emphasized two fundamental aspects in his trajectory: the critical revision of the modern project - and the production of space in results - and a new critical and contextual contemporary art perspective on urban life, which intends the work of art towards a hybrid able to transit the artistic and extra-artistic worlds. Like many other artists, Mano has been demonstrating that the artistic work is increasingly imbricated by the experience of daily life, aesthetically and politically attentive to the urban problematic and its contradictions.

KEYWORDS: Rubens Mano; contemporary art; art and city; urban life. 


\section{SUMÁRIO}

\section{INTRODUC̣ÃO}

19 Motivações e hipótese

270 objeto de estudo

29 Metodologia de investigação

32 A inscrição do artista

0 arquiteto, 0 artista e a universidade

A experiência fotojornalística

Fricções da década de 1980

A cidade e a construção de lugares

47 CAPÍTULO 1 REFLEX̃̃ES ACERCA DA RELAC̣ÃO ARTE-CIDADE

500 papel estruturante do ambiente urbano

55 Práticas contextuais: o espaço e o lugar

66 Poéticas emergentes

$68 \quad 0$ ambiente paulistano

$75 \quad 0$ hibridismo dos meios

81 CAPÍTULO 2 IMAGENS PERFORMÁTICAS

830 ser urbano nômade

87 A construção espacial através da fotografia

93 bueiro (1999) e disponha (2001)

97 A condição silenciosa

99 A transfiguração do observador em perceptor

100 A fotografia como índice

105 casa verde (1997) 
Espaços residuais

125 entre (2003) e súbitas paisagens (2006-07)

134 Imagens performáticas

136 A construção de espaços

137 Fotografia, entre percepção e experiência

141 CAPÍTULO 3 O ESPAC̣O EM ATO

147 Anos 1990: as novas práticas contextuais

1510 caso Arte/Cidade em São Paulo

158 Contexto paulistano, "local" e "global"

0 debate da crítica

167 Arte/Cidade 2: curadoria e contexto

173 detetor de ausências (1994)

179 A experiência da duração

181 A dissolvência da fotografia

186 Desrealização da cidade, deslocalização do sujeito e deslocamento da obra

193 calçada (1999)

Conectividade

A adesão do público

0 espaço "entre"

Outros sítios

vazadores (2002)

0 projeto para a Bienal

A arquitetura (e a obra-arquitetura)

0 público

A instituição..., a curadoria e as negociações

Êxito ou fracasso?

0 paradigma da crítica institucional

Arte pública?

CAPÍTULO 4 HABITAR O MODERNO

\section{CONSIDERAC̣̃̃ES FINAIS}

\section{APÊNDICE}

Aproximações entre Mano e Matta-Clark 
introdução 


\section{MOTIVAC̣ÕES E HIPÓTESE}

A experiência intensa de viver numa megalópole como São Paulo certamente foi o principal motor das inquietações elaboradas como hipóteses iniciais desta pesquisa, sistematizadas em âmbito acadêmico para a realização do projeto de doutorado na Faculdade de Arquitetura e Urbanismo da Universidade de São Paulo. Dentre todas as cidades brasileiras, a capital paulista desponta como aquela que expressa de forma mais intensa e emblemática as contradições de um país que buscou se modernizar e lançar-se ao futuro, mas que teve seu "espírito moderno" constantemente posto à prova diante das dificuldades de construção de uma esfera pública e de uma sociabilidade urbana democrática na periferia do capitalismo (e que envolveu, particularmente no caso brasileiro, suas heranças coloniais).

A isso adiciona-se, no contexto de São Paulo, o fato desta cidade ter sido movida desde sua fundação pelo binômio demolição-construção, e de que nos anos 1990 ela "conquistou" um lugar no jogo econômico internacional como "cidade global". O choque do modus operandi (moderno) da cidade com os processos da globalização produziram não só um tecido urbano descontínuo e difuso - pelo qual os sistemas de produção não mais coincidem com os sistemas urbanos, materializando-se na dispersão e na fragmentação dos processos de ocupação do território -, mas também uma cidade que passou a operar em duas velocidades, a saber: a cidade real, onde a vida cotidiana se desenrola e produz socialmente o espaço; e a virtual, na qual ocorrem as trocas informacionais que conectam os centros de controle da economia global, viabilizadas pela tecnologia. ${ }^{1} \mathrm{~A}$ experiência paulistana das últimas décadas, portanto, vem enfrentando duas situações justapostas: a que é fruto da herança moderna, vivenciada em sua incompletude e

Sobre a influência dos avanços da tecnologia da informação na forma de ocupação do território, cf. Castells, Manuel. O espaçç de fluxos. A sociedade em rede. São Paulo: Paz e Terra, 1999, pp. 403-456. O tema será devidamente abordado no Capítulo 3 desta tese. 
em sua fragmentação, e a da cidade contemporânea e suas novas dinâmicas virtualizadas.

De modo geral, a sobreposição de velocidades é um fenômeno mundial, verificado nas principais cidades do globo, e foi apontado pela filósofa Otília Arantes em 1998 nos termos de uma cidade instável, decorrente de uma situação de transição para o moderno abortada:

As sociedades funcionam atualmente com duas velocidades, a dos integrados no circuito internacional e a da grande massa dos perdedores na corrida da competitividade, e que já não ameaçam mais segundo a divisão tradicional das classes antagônicas, inviabilizando assim o compromisso social democrata do planejamento urbano conforme os modernos. ${ }^{2}$

Para o urbanista italiano Bernardo Secchi, a instabilidade própria da cidade contemporânea se deve à sobreposição de diferentes temporalidades no território: "paradoxalmente, a cidade contemporânea é o lugar da não contemporaneidade, que nega o tempo linear, a sucessão ordenada de coisas, de acontecimentos e comportamentos dispostos ao longo da linha do progresso como foi imaginado pela cultura moderna". ${ }^{3} \mathrm{Na}$ cidade atual, os indícios de outrora se proliferam e a transformam numa colcha de retalhos, onde os diversos tempos se sobrepõem e se justapõem, tal como a imagem de um puzzle.

A nova configuração da cidade, entendida por Secchi, carrega em si mesma a dialética entre a modernidade e o contemporâneo, operando no equilíbrio entre as polaridades urbanas: separação $\times$ mistura; concentração e circunscrição $\times$ dispersão e fragmentação; continuidade $\times$ descontinuidade; universalidade $\times$ diferença; padronização $\times$ diversidade; ordenação $\times$ flexibilidade; movimento mecânico $\times$ fluxos materiais e virtuais.

2 Arantes, Otília B. F. Urbanismo em fim de linha e outros estudos sobre o colapso da modernização arquitetônica. [1 edição 1998]. São Paulo: Edusp, 2001, p. 130

3 Secchi, Bernardo. Primeira lição de urbanismo. [1ª edição 2000]. São Paulo: Perspectiva, 2015, p. 90.
A justaposição e a sobreposição de temporalidades foi igualmente analisada pelo teórico norte-americano Fredric Jameson como

o desaparecimento do sentido da história, o modo pelo qual o sistema social contemporâneo como um todo demonstra que começou, pouco a pouco, a perder a sua capacidade de preservar o próprio passado e começou a viver em um presente perpétuo, em uma perpétua mudança que apaga aquelas tradições que as formações sociais anteriores, de uma maneira ou de outra, tiveram de preservar. ${ }^{4}$

As evidências da generalização do fenômeno urbano das cidades e o choque do moderno com o contemporâneo, operado na fragmentação do território e numa sociedade em rede, também foram elaborados por teóricos importantes, tais como Henri Lefèbvre, David Harvey e Manuel Castells, os quais, ao lado de Arantes, Secchi e Jameson, ajudarão a compor o panorama das análises sobre a problemática urbana e sobre a condição contemporânea dos modos de vida nas cidades.

Diante desse quadro, chamou a atenção um interesse renovado da arte pela cidade e pela problemática urbana a partir dos anos 1990. Renovado porque em outros momentos da história da arte moderna ocidental, alguns artistas já tinham se colocado diante da emergência da vida urbana nas cidades e a reelaborado em termos estéticos. Dentre alguns exemplos, pode-se citar as vanguardas artísticas dos anos 1920. De acordo com a crítica norte-americana Rosalyn Deutsche:

Na história do modernismo, tal como foi especialmente traduzido pela história da arte, a cidade ocupa um papel central. O realismo, o impressionismo, o cubismo, o futurismo, o expressionismo, e mesmo

4 Jameson, Fredric. Pós-modernidade e sociedade de consumo, Novos Estudos, Cebrap, São Paulo, n. 12, jun. 1985, P. 26. 
a pintura modernista na sua totalidade, todos são tradicionalmente

ligados ao crescimento da metrópole. 5

A hipótese que se apresentou de início para a pesquisa é a de que, a parti da década de 1990, a experiência urbana das grandes cidades, incluindo suas dinâmicas e contradições, tem conquistado cada vez mais a atenção dos artistas em suas práticas, tanto no cenário nacional como no internacional, e caberia entender aqui quais seriam as situações e motivações que as diferenciam dos contextos anteriores. De início, dois aspectos sobressaíram como vetores dessa hipótese: de um lado, além do advento da globalização, que teria modificado radicalmente as dinâmicas das cidades globais e a produção do espaço, a população urbana tornou-se maioria em território mundial no despontar do século XXI; de outro, uma parcela significativa da produção de arte contemporânea passou a operar o real a partir de uma prática contextualista, que se mostrará central no debate sobre a relação arte-cidade e sobre a questão da produção do espaço na cidade. Tais práticas não mais se restringem a uma atuação física no substrato urbano; suas formalizações se amplificaram sob diversos meios - registros, cartografias, fotografias, transposições, documentos-, deslocados do contexto e apresentados como reminiscência e/ou reconstrução em resposta às questões urbanas.

A definição de arte contemporânea concebida por Ricardo Basbaum e Eduardo Coimbra, publicada no texto "Tornando visível a arte contemporânea” em 1995, reafirma de algum modo a importância do contexto para a produção do período. Segundo ela, o trabalho de arte seria uma síntese plástica que se constitui como "uma singularidade a partir do encontro su-

5 "In the history of modernism, especially as it has been translated into art history, the city occupie 5 " central role. Realism, impressionism, cubism, futurism, expressionism, indeed modenist painting in its entirety, are all traditionally linked to the growth of the metropolis." Deutsche Rosalyn. Altenative Space. Wallis Brian (ed). If Vou Live Here: The City in Art Theory and Sociat Activism. A Arojet by Martha Rosler. Seattle: Bay Press, 1991, p. 46. jeito-matéria-contexto". ${ }^{6} \mathrm{O}$ encontro a que os autores se referem pode ser traduzido aqui como uma prática contextualista, identificada na produção de arte das últimas décadas. De certa forma, ela é herdeira dos anos 1960, quando um tipo de obra site-oriented tinha reposto o problema do lugar no debate contemporâneo em contraposição às autonomias do moderno (a exemplo das poéticas minimalista e pós-minimalista). Percebe-se que boa parte da produção contemporânea vem buscando redefinir a ideia de lugar e anunciar de que maneira questões políticas, sociais e econômicas precisam ser igualmente consideradas na proposição estética de um trabalho de arte.

Dentre as evidências do crescente interesse da arte contemporânea pelas mudanças ensejadas na cidade está a recorrência com que artistas têm empregado elementos da materialidade própria do meio urbano nos seus trabalhos. Frequentemente nos deparamos com o uso de tijolos, elemento vindo do ambiente construtivo edificante; com a apropriação da linguagem comunicacional de outdoors, letreiros e sinalizações, que fazem da cidade um grande espetáculo luminoso; com a subversão do uso de câmeras de vigilância, grades e sensores, uma parafernália do mercado de segurança que converte a noção de privacidade em privatização; ou ainda com o emprego de conduítes, chapas, parafusos e rebites, matéria industrial reapropriada como negativo de sua positividade; entre outros elementos.

Essas evidências se acentuam ainda mais no contexto das práticas constituídas a partir de São Paulo. De acordo com a historiadora da arte Aracy Amaral, se há algum denominador comum na produção paulistana, este seria a relação peculiar entre arte e indústria:

Sempre me parecia que São Paulo não tinha estilo, no sentido de que os artistas paulistanos vivem nesta cidade louca em seu ritmo, pressão e ansiedade constantes, espaço de concreto quase desprovido de

6 Basbaum, Ricardo e Coimbra, Eduardo. Tornando visível a arte contemporânea [1995]. Basbaum, Ricardo (org.). Arte contemporânea brasileira: texturas, diccões, ficcões, estratégias. Rio de Janeiro: Rios Ambiciosos, 2001, p. 348 
paisagem, sua poética semioculta no meio urbano, na discrição dos interiores das casas e apartamentos. No entanto, agora me parece bem perceptível uma espécie de "escola" paulistana, mais que paulista, com características que podem torná-la reconhecível. Se isso era visível no desejo dos artistas concretos, que buscavam a aproximação com o suporte industrializado [...] nos anos 1950, na década seguinte era visível igualmente na postura de Wesley Duke Lee, militando na publicidade [...], ou com Willys de Castro, Barsotti e Wollner, criando marcas e logotipos para empresas, ou de Geraldo de Barros desenhando móveis [...]. A peculiar relação arte/indústria é percebida com transparência em Nelson Leirner a partir de fins desses anos 1960.

O fio condutor da relação arte/indústria segue adiante no texto de Amaral através de exemplos contemporâneos, tais como: Cuto Lacaz, no seu senso de humor conjugado com a invenção a partir da mecânica e das engrenagens; Artur Lescher, com sua precisão, acabamento e experimentação com materiais; na racionalidade poética de Carmela Cross; na materialidade industrial recorrente nos trabalhos de Ana Maria Tavares; no desejo de experimentação de processos em Regina Silveira; ou ainda nas apropriações de Jac Leirner, oriundas da sociedade de consumo e ordenadas com um afã classificatório exemplarmente metropolitano.

A partir dos anos 1990, as evidências de um mundo material industrial se dissipam em outras formulações da cidade paulistana, cujas bases industriais passam a conviver com a nova dinâmica dos fluxos. Como, por exemplo, nos modos como a cidade é refundada enquanto campo identitário no sentido da produção do espaço pela e na prática artística, seja por estratégias cartográficas, pela reconstrução da memória ou mesmo pela

7 Amaral, Aracy A. Arte paulistana [1998]. Textos do trópico de capricórnio: artigos e ensaios (1980-2005). Vol. 3: Bienais e artistas contemporâneos no Brasil. São Paulo: Editora 34, 2006, p. 304. atuação do corpo. Elas também se expressam por meio de temas como ruína e impermanência, a oposição entre o real e o virtual, a espetacularização da vida urbana e a reificação da própria cidade como imagem. Ver-se-á adiante como a obra de Rubens Mano amplia a perspectiva paulistana da problemática da matéria industrial, sobrepondo-a a um problema de natureza transversal, que inclui o cultural, o social e político.

Nessa profusão de pontos de vista sob os quais a cidade é tensionada, fazse necessário tomá-la não apenas em sua dimensão física - nos seus aspectos arquitetônicos e edificados (incluindo escalas, relações de proporção, materialidade, texturas e formas), na sua fisionomia paisagística (em sua existência imagética) e na sua dimensão territorial (em seus referenciais que determinam o lugar no território) -, mas também, e dialogicamente, em sua dimensão social, das relações tecidas entre os sujeitos e o local que transformam o espaço vivido num campo de conflito permanente. O que equivale a pensar a cidade num espectro mais amplo, da vida urbana, ao considerar primordial o cotidiano e a experiência dos sujeitos no lugar onde se promovem encontros, conflitos, conhecimentos e reconhecimentos recíprocos dos modos de viver, no qual se tecem relações sociais, políticas e culturais.

Sendo assim, desde o início da pesquisa, o projeto da tese se colocou como desafio examinar uma história da arte recente, no cruzamento e na mútua impregnação entre a prática artística e a vida urbana. A década de 1990 foi eleita como marco significativo de uma mudança estrutural tanto nos domínios da arte quanto nos das cidades, que desencadeou uma série de transformações na produção contemporânea e no próprio campo da crítica. Desde meados dessa década, uma parte significativa dos trabalhos de arte tem se voltado para questões urbanas prementes desenvolvidas no tecido social da cidade, das quais destacam-se: a falência da urbanística moderna (do planejamento e da racionalização); os modos como a cidade e a vida urbana hoje atualizam questões deixadas em aberto pelo projeto moderno; as dinâmicas que se instauram a partir de uma cidade múltipla e difusa, financeirizada e presentificada; a relação entre as instâncias pública e privada desenhadas nos âmbitos da arquitetura e da cidade (e que inclui a crise do espaço públi- 
co); e as implicações dessa relação nas suas dimensões social, política e cultural. Portanto, nos trabalhos de investigação acerca desse tipo de produção artística do período, dois aspectos se mostraram fundamentais: pensar uma história da arte contemporânea e, ao mesmo tempo, operar num campo in terdisciplinar, buscando estabelecer conexões com a história da cidade e com o urbanismo.

Com especial interesse na arte produzida a partir de São Paulo, dada a relevância que a cidade e os modos de viver nela ensejados apresentavam para o debate sobre a condição contemporânea da vida urbana, a pesquisa elegeu como objeto de estudo um conjunto de obras do artista Rubens Mano, sobre o qual serão tecidas as análises. A obra do artista foi tomada como modelar das transformações da vida urbana conformadas no e pelo espaço da cidade sob dois aspectos fundamentais: quanto à revisão crítica do projeto moderno, e quanto à produção de espaço e os novos modos do viver urbano na contemporaneidade. Mano e tantos outros artistas vêm demostrando que o fazer artís tico está cada vez mais imbricado à experiência do cotidiano, atento estética e politicamente à problemática urbana e suas contradições.

\section{O OBJETO DE ESTUDO}

O trabalho investigativo, assim, tem como pano de fundo o contexto paulistano da arte contemporânea, majoritariamente, e como estudo de caso um conjunto de obras de Rubens Mano produzidas a partir de São Paulo e em grande parte motivadas pelos desafios que rondam o artista diante da vida urbana em transformação. São obras que ressignificam a experiência do viver paulistano e suas especificidades. De par com uma aproximação inicial dos trabalhos de Mano, a pesquisa optou por estabelecer alguns pressupostos teóricos sobre o ambiente urbano contemporâneo, que serão apresentados no Capítulo 1 desta tese. Em seguida, o estudo do conjunto de proposições artísticas selecionadas vem colaborar em grande medida para o encontro desses pressupostos, e compõe o corpus teórico principal da tese, desenvolvido nos três capítulos consecutivos, a saber: Capítulo 2. Imagens performáticas; $\mathrm{Ca}$ pítulo 3. O espaço em ato; Capítulo 4. Habitar o moderno.

Cada um dos três capítulos dedicados ao artista é organizado em torno de um pequeno agrupamento de 2 a 5 trabalhos, reunidos segundo afinidades estéticas, contextuais e discursivas, evitando privilegiar uma leitura cronológica de sua produção, assim como uma aproximação por técnicas e/ ou materiais empregados. Apesar de reunidas num determinado conjunto, o estudo das obras também buscou estabelecer conexões entre os conjuntos, procurando não enquadrar o trabalho dentro de uma única perspectiva de leitura. Essa organização possibilitou uma maior imersão nas obras, permitiu identificar uma certa coerência no discurso do artista, nem sempre linear e "dedutível", e abriu brechas para tecer cruzamentos dos trabalhos entre si, e deles com a obra de outros artistas - fossem estes nacionais ou internacionais, contemporâneos ou extemporâneos a Mano.

Neste sentido, a seleção das obras de Mano não tem a pretensão de esgotar a análise da produção do artista como um todo, nem tampouco privilegia uma sequência temporal de proposições; busca, sim, criar uma constelação de trabalhos que operam a partir da problemática urbana. Um 
primeiro esforço, resultante da escolha do conjunto, foi identificar uma espécie de denominador comum entre elas e entender em que medida esse coeficiente correspondia a certas práticas artísticas movidas pela experiência "paulistana" da produção do espaço. Aos poucos, a familiaridade com os trabalhos foi evidenciando três aspectos centrais na obra do artista: a fotografia como uma forma de aproximação com a cidade, e como ela se hibridizou a outros meios na passagem dos anos 1980 aos 1990; a produção do espaço na cidade, fruto da dialética entre a forma moderna e a condição contemporânea, e que pressupõe esse espaço como um constructo cultural para além de suas evidências físicas; e a ideia da experiência como obra, que reconecta o sujeito à sua vivência tanto da arte quanto da cidade.

Não por acaso, a capital paulista mostrar-se-á a grande matéria-prima da obra de Mano, mesmo quando ele olha para outras cidades, como Brasília. Em certa medida, São Paulo será identificada como a face mais evidente do espírito modernista do país, mais até que Brasília ${ }^{8}$ - que, neste estudo, aparecerá como sua antítese: uma cidade refém da promessa de futuro que não se cumpriu e que foi congelada no presente pelo seu tombamento como patrimônio histórico e cultural.

Enquanto Brasília representava o manifesto artificial e um tanto quanto caipira do Brasil moderno, São Paulo sempre foi moderna de verdade. A arquitetura, os museus de arte, os eventos culturais, um ambiente urbano sempre em transformação e a mistura de culturas suscitam a "intensificação da estimulação nervosa" que Georg Simmel identificou como uma das características mais fortes da vida urbana do século XX. ${ }^{\circ}$

8 A crítica ao projeto moderno na arquitetura e no urbanismo, que tem Brasília como exemplo brasileiro paradigmático, será o tema do Capítulo 4. Habitar o moderno desta tese.

9 Andreoli, Elisabetta e Santos, Laymert Garcia dos. Arte pública, cidade privada. Peixoto, Nelson Brissac (org.). Intervenções urbanas: arte/cidade. São Paulo: Senac, 2002, p. 284. (O artigo foi originalmente publicado na revista Third Text, n. 45, Londres, inverno 1999).

\section{METODOLOGIA DE INVESTIGACÃO}

Para examinar a natureza interdisciplinar da obra de Rubens Mano, e situá-la no universo da arte contemporânea em geral - e na paulistana, em especial -, a presente pesquisa procurou desenvolver as análises em duas frentes concomitantes e interpenetráveis: de um lado, buscou estabelecer alguns pressupostos teóricos sobre as mudanças ensejadas na vida urbana nas últimas décadas e situar, na medida do possível, o estado da questão; e, de outro, fortalecer a importância de um estudo aprofundado das obras e sua fortuna crítica (incluindo os processos de desenvolvimento, desde a concepção e o contexto até sua formalização e circulação), como método de aproximação e investigação sobre a produção do artista. Este estudo constituirá o corpus significativo da tese, do qual espera-se extrair algumas considerações finais. De par com a opção metodológica, a pesquisa centrou-se em um número reduzido de obras, evitando estabelecer uma espécie de genealogia da produção do artista desenvolvida ao longo de 30 anos.$^{10}$ No lugar de abordar a totalidade dos trabalhos como um conjunto coeso e consecutivo, privilegiou-se uma imersão em poucos exemplares, tidos como singulares e representativos do artista no que diz respeito a uma elaboração mais direta da experiência da cidade e da problemática urbana contemporânea.

A partir daí, além de tecer certos cruzamentos das obras de Mano entre si, tal mapeamento relacional será oportunamente posto em diálogo com obras de outros artistas do universo paulistano. Ao buscar desenhar possíveis filiações de Rubens com uma certa produção local - a exemplo de artistas como Regina Silveira e Julio Plaza -, a pesquisa perseguirá as motivações de Mano diante da experiência urbana da cidade, circunstanciada no ambiente artístico paulistano, industrial e cosmopolita, universitário e híbrido, mo-

10 Cabe observar que, apesar de longa, sua produção não é extensa, e geralmente é formulada em termos públicos ou por ocasião de exposiçōes, individuais e coletivas, ou via projetos pessoais realizados, por exemplo, por meio de editais. 
derno e contemporâneo. Exemplares mais jovens da arte brasileira, como Clarissa Tossin e Marcelo Cidade, aparecem em análises pontuais e ajudam a entender certa tendência da produção nacional a se posicionar criticamente em relação à herança moderna (tanto da arquitetura quanto da arte), sob a perspectiva da produção do espaço e da vida urbana. Apesar de terem iniciado suas práticas mais recentemente, a partir dos anos 2000, eles propõem obras que fazem da arte um campo fértil para tocar a problemática urbana na virada do século XXI.

Na busca de um sentido histórico para se pensar a produção brasileira no contexto global, outras filiações também serão tecidas, tais como a possibilidade de desvendar a anarquitetônica de Cordon Matta-Clark (1943-1978) em certos trabalhos do artista paulistano. O diálogo estabelecido entre os dois tem o propósito de comparar suas práticas, ambas mobilizadas pelas transformações urbanas de duas grandes metrópoles e operadas a partir das noções de intervenção, fotografia e performance. A conjunção da arquitetura com a fotografia e o interesse em mover-se pelo território urbano na busca de lugares adjacentes e/ou abandonados em Mano foram postos em confronto com o paradigma city-related de Matta-Clark, desenvolvido na Nova York dos anos 1960 e 1970, cujas análises se desdobram no Apêndice desta tesa.

Paralelamente, a pesquisa procurou esquivar-se de certos rótulos empregados pelo senso comum ou por uma crítica classificatória, e por isso mesmo tidos como reducionistas e pouco "funcionais". Evitou-se ao máximo utilizar noções pré-concebidas sobre "arte pública”, "arte urbana”, "intervenção urbana”, ou mesmo empregar termos enrijecidos nas últimas décadas, como o site specificity (sendo que, as vezes em que eles aparecem, são para tensioná-las como efetivos, permanentes e/ou totalizantes). Em lugar disso, as análises buscarão se inspirar numa perspectiva mais aberta, sem determinações apriorísticas de técnica, linguagem ou categoria, ao priorizar as questões que emergem dos próprios trabalhos, o que eles têm de singular e potente no desejo de trazer à tona as contradições da vida produzida nas grandes cidades, nos seus aspectos sociais, políticos e culturais.

Em consonância com o que Basbaum e Coimbra defenderam em 1995, a pesquisa partiu do princípio de que para se aproximar do campo plástico contemporâneo deve-se criar novas modalidades de espaço e tempo decantadas das particularidades de cada obra, determinadas pela rede de relações que a constitui.

Para tornar visível a produção contemporânea é necessário o emprego de métodos corretos, de modo a extrair de um conjunto de atividades caóticas e disformes os contornos precisos de um acontecimento artístico. A dificuldade desse trabalho é a exigência de estar sempre disponível para recriar parâmetros críticos, reconhecendo a primazia das obras na deflagração desse processo; do contrário, uma reflexão calcada em preconceitos tornar-se-ia uma especulação estética vazia e estéril."

Rubens a seu modo carrega um repertório crítico sobre a vida urbana na transição do moderno ao contemporâneos; e, estes, aparecem sobrepostos no tempo. Suas proposições aportam a construção de "lugares dentro de lugares", ${ }^{12}$ nos termos do artista - ou o que Deutsche nomeara como "alternative spaces" ${ }^{13}$-, singularizando uma certa condição atual da cidade e despertando as potencialidades da obra vivida como uma experiência. A prática desenvolvida pelo artista, em conjunção com suas elaborações discursivas, prestar-se-á como exemplar na compressão das questões urbanas anunciadas no Capítulo 1 da tese.

11 Basbaum e Coimbra, op. cit., p. 346

12 O termo é empregado pelo artista no título de seu artigo publicado na revista Urbania. Cf. Mano, Rubens. um lugar dentro do outro, Urbania, n. 3. pp. 101-111, 2006b.

13 ' "(...) through the projects' exploration of 'the production of space', Roesler sought to transform conventional perceptions and uses of the site, and thereby produce an alternative social space". Deutsche, op. cit., p. 45 


\section{A INSCRICCÃO DO ARTISTA}

Concebida a partir de São Paulo, a obra de Rubens Mano tem sido incessantemente motivada pela experiência cotidiana da cidade, do viver metropolitano, diante das questões que ressurgem da problemática urbana em meados dos anos 1990 - cuja origem reside na passagem dos anos 1960 aos 1970, quando o urbano passa a ser estruturante. Os trabalhos do artista têm variado em ações endereçadas à cidade, realizadas no espaço público, intervenções no trânsito entre o espaço aberto da cidade e o espaço fechado (institucional) da arte, ou mesmo proposições trazidas para dentro dos contornos legitimados do meio artístico (como galerias, museus e bienais, principalmente).

A produção que se inicia em meados dos anos 1980, e que toma corpo ao longo dos anos 1990, é orientada por dois vetores principais e justapostos, que permeiam o conjunto das proposições abordadas nos capítulos dedicados à sua obra (Capítulos 2, 3 e 4 desta tese). Um primeiro vetor é a fotografia, tomada como uma linguagem (e uma técnica) originária da cultura moderna industrial, urbana por excelência, e ampliada como meio expressivo no universo da arte contemporânea e pelo qual o artista se aproxima da cidade e passa a reinterpretá-la. O segundo diz respeito ao lugar, que equivale ao contexto a partir do qual a obra é elaborada. Este é tomado pelo artista não apenas em seus aspectos físico e espacial, decorrentes em alguma medida da formação do jovem arquiteto, mas também e simultaneamente em suas dimensões políticas, sociais e culturais, que levaram Mano à elaboração de novas práticas transdisciplinares mobilizadas pela questão da produção do espaço na cidade. De certo modo, o segundo aspecto encontra respaldo nas formulações do historiador Michel de Certeau sobre o espaço praticado $0^{14}$ - um espaço definido pelas relações nele engendradas - e do antropólogo Marc

14 Cf. Certeau, Michel de. Relatos de espaço (Capítulo IX). A invenção do cotidiano. Petrópolis/R):Vozes, 1994, pp. 199-217.
Augé sobre o lugar antropológico ${ }^{15}$ - aquele caracterizado por seus aspectos identitários, relacionais e históricos. ${ }^{16}$

\section{O ARQUITETO, O ARTISTA E A UNIVERSIDADE}

Para uma ampla compreensão da natureza da obra de Rubens Mano é preciso considerar de antemão sua aproximação com o meio universitário, iniciada na década de 1980 e que vai caracterizar sua atuação como artista até hoje. Tal aproximação lhe trouxe uma perspectiva tanto da pesquisa e suas metodologias processuais (incluindo o tempo dilatado desta), e da reflexão sobre o próprio trabalho (passando por uma certa lateralidade em relação ao mercado, no caso das artes visuais), como também de sua capacidade interdisciplinar, adquirida da formação como arquiteto/urbanista e da formulação das Poéticas Visuais que ocupou o lugar da antiga segmentação das técnicas artísticas. É nesse cenário que Mano assenta as bases de sua produção artística, como um estudioso da dimensão da arquitetura e do urbanismo; o artista desenvolve trabalhos no conhecimento dos processos envolvidos na mudança paradigmática da vida urbana, os quais se relacionam com momentos da cidade em transformação.

Entre 1980 e 1984, Mano estudou na Faculdade de Arquitetura e Urbanismo de Santos. Ao final da graduação, ao invés de conceber um projeto arquitetônico convencional para o trabalho de conclusão do curso, tal como a maioria dos estudantes, Rubens e seu colega Álvaro definiram como método para a elaboração do TCC a realização de uma viagem de estudo sobre arquitetura andina. Por meio da pesquisa de campo, os estudantes buscaram investigar a natureza da arquitetura, do espaço e da paisagem seus materiais, formas e ocorrências - nos países que fazem fronteira com o

15 Cf. Augé, Marc. O lugar antropológico. Não-lugares: introdução a uma antropologia da supermodernidade. Campinas: Papirus, 1994, pp. 43-69.

6 Tais conceitos serão desenvolvidos com especial atenção no Capítulo 1 da tese 
Brasil. ${ }^{17}$ Diferentemente das "velhas" pranchas de apresentação de projeto com desenhos técnicos e normografadas, o resultado final da pesquisa fo apresentado sob a forma de duas projeções audiovisuais simultâneas que acompanhavam um caderno de campo.

A experiência no território andino marcou definitivamente o conjunto da obra que viria a ser construída pelo jovem arquiteto, recém-formado. Não só a aprendizagem organizacional em produzir a viagem, que implicou uma es perteza para lidar com variáveis muito diversas e com múltiplas articulações entre pessoas e empresas, mas também a acuidade de um olhar significante sobre a paisagem - que aprendeu a registrar para além do real, uma elabo ração sobre o real - seriam aspectos fundamentais no desenvolvimento do percurso do artista.

A formação inicial da graduação tinha lhe proporcionado, além de um conhecimento dos conteúdos e das ferramentas específicos da prática arquitetônica, uma experiência inicial com a técnica fotográfica. Na entrevista concedida em seu ateliê, em agosto de 2015, o artista recorda que o ambiente universitário permitiu seu primeiro acesso a um laboratório químico: "é ali que eu começo a ter [contato] de uma forma mais técnica... um curso básico de

$$
17 \mathrm{Em} 1984
$$

17 Em 1984, os dois jovens estudantes de arquitetura se aventuraram pela América do Sul, a bordo de uma Kombi, conduzidos pela curiosidade sobre a natureza da arquitetura andina, que tinham conhecido nas aulas do professor Caracol (apelido de Wilson Ribeiro, então professor de projeto na Faculdade de Arquitetura e Urbanismo de Santos). A viagem durou 120 dias, durante os quais a dupla percorera 23.000 quilômetros do território sul-americano, a partir de São Paulo, passando pela Argentina, Bolívia, Peru e Chile. Foram sete meses para: 1. organizar os temas, objetos de estudo e pesquisa, que por sua vez determinaram os lugares a serem percorridos - lugares de pouso, pesquisa e descanso; 2 identificar possiveis interlocutores que pudessem auxiliá-los no escopo da viagem (representados por fim nas figuras da historiadora de arte Aracy Amaral, do arquiteto Hugo Segawa e do geógrafo Milton Santos, além do professor Caracol): 3 . e armar a logística de viagem com eventuais patrocinadores, no intuito de viabilizar o projeto financeiramente (desde a Volkswagen, passando pela Minalla até a Casa Thomaz Henriques, especializada em ferragens). De volta a Brasil, cadernos de anotacõos, a Casa thos dos percursos, registros fotográficos e depoimentos colhidos, tudo isso foi processços, orgnizado para a apresentaça final Inicialmente resistentes a formato, os professocs da bac organizado para a apresentaçao final. Incialmente restentes ao forma to, os professores da banca trevista com o artista realizada por mim em seu ateliê, em 3 de agosto de 2015). fotografia para saber manipular, usar o laboratório em branco e preto etc.". ${ }^{18}$

Uma segunda aproximação de Mano com o ambiente universitário ocorreu no início da década de 2000 , quando o artista decide sistematizar uma reflexão sobre seus trabalhos e suas práticas, que resultou na dissertação de mestrado intervalo transitivo, defendida por ele no Departamento de Artes Plásticas da ECA-USP, em 2003. Vale assinalar que, não por acaso, o artista escolheu o professor Julio Plaza (1938-2003), dentre os docentes do departamento à época, para orientar sua pesquisa. Plaza detinha um amplo domínio sobre os estudos da fotografia, que envolviam, dentre outros aspectos, a relação entre arte e técnica e suas implicações no campo da comunicação e da semiótica. Além disso, o professor acumulava uma experiência singular vivida na Universidade de Porto Rico, no início dos anos 1970, onde promoveu situações arquitetônicas didático-experimentais de natureza conceitual, incluindo oficinas com artistas da minimal art norte-americana, que marcariam sua produção como artista-pesquisador ao regressar ao Brasil, em 1973.

O trabalho do mestrado apresentou-se como uma importante elaboração teórica acerca das obras realizadas entre os anos 1990 e a primeira metade dos anos 2000, e se mostrou fundamental para as proposições que se desdobraram a partir dali. No escopo desta tese, intervalo transitivo serviu como fonte de pesquisa crucial, pela qual foi possível uma aproximação das referências teóricas eleitas pelo artista na concepção das obras e em suas elaborações conceituais. Elas exprimem, tal como Rubens procura fazer em sua prática artística, uma busca incessante em se estabelecer um campo interdisciplinar entre os conhecimentos - sejam eles artísticos e/ou arquitetônicos, históricos e/ou geográficos, e sociológicos e/ou filosóficos.

18 Entrevista com o artista realizada em seu ateliê, São Paulo, 3 de agosto de 2015. 


\section{A EXPERIÊNCIA FOTOJORNALÍSTICA}

Desde meados dos anos 1980, arquitetura e fotografia se uniram de modo fecundo na sua experiência profissional e na sua vivência da cidade. No fina da década, Rubens vai trabalhar na Folha de São Paulo como fotojornalista, fato que considera determinante para sua produção futura, uma vez que suas atribuições no jornal permitiam-lhe conhecer a cidade de uma forma que não conhecia antes, com acesso a lugares a que dificilmente iria se não fosse naquela situação de trabalho. ${ }^{19} \mathrm{O}$ aprendizado do deslocamento na cidade, de inventar novos caminhos a cada dia, facilitou uma compreensão do lugar, impressa definitivamente nas suas intenções artísticas e nos seus modos de operar futuros. O interesse pela paisagem e pela arquitetura se desdobrou num olhar voltado para o urbano e para a vida urbana, em sua extensão.

A experiência da cidade apreendida pelo olhar fotográfico de Mano remete a uma prática errática do caminhar pela metrópole, cuja natureza tomar-se-á como a existência nômade do ser urbano, a partir dos pressupostos teóricos do sociólogo francês Michel Maffesoli, que serão expostos mais adiante, no Capítulo 2. Tanto a fotografia como o hábito de percorrer a cidade "despretensiosamente" têm origem numa cultura urbana ensejada na modernidade. $O$ deslocamento cotidiano da atividade jornalística chegou a ser comparado por Walter Benjamin à alegoria urbana do flâneurna Paris do século XIX. Segundo o filósofo alemão, o deslocamento efetuado naquela atividade - por meio da qual o sujeito reinventa novos percursos e faz do seu "tempo livre" gasto na rua o seu tempo de trabalho - era a base social da flânerie. "O jornalista se comporta à maneira do flâneur, como se até mesmo ele o soubesse". ${ }^{20} \mathrm{O}$ flâneur

19 Rubens permaneceu um ano e meio no jornal. Em depoimento, o artista relata que, no dia a dia do jornalismo, o fotógrafo se deslocava com o motorista, contratado pela Folha para levar os repórteres; porém, como não gostava de acompanhar o repórter, dada a existência de uma relação muito hierarquizada deste, quase preconceituosa mesmo, que via na fotografia uma mera ilustração dos fatos, Mano frequentemente chegava mais tarde. (Informações colotas na entrevista realizada no atelie Mano frequentementechegava ma

20 Benjamin, Walter Charles Baudelaire, um lírico no auge do capitalismo. São Paulo: Brasiliense, 1989, p. 225 seria essa figura da modernidade que se perde anonimamente nas multidões dos grandes centros urbanos, mas que, ao mesmo tempo, se deleita com as vitrines de luxo dos corredores comerciais das passagens da capital francesa.

No início do século $\mathrm{XX}$, a fotografia despontou como uma das expressões mais evidentes das conquistas da indústria, e, por consequência, é das linguagens artísticas a que mais representa a lógica e a cultura industriais que caracterizaram a vida moderna nas grandes cidades. No livro O fotográfico, a crítica de arte norte-americana Rosalind Krauss identifica na declaração do escritor francês Pierre Naville, publicada na revista Revolution surréaliste em 1925, o embate travado entre a nova cultura moderna, urbana, e a tradição acadêmica: "Só conheço do bom gosto o desgosto. Reis, reis da embromação, lambuzem suas telas! Ninguém mais ignora que a pintura surrealista não existe! [...] A memória e o prazer dos olhos, esta é toda a estética". ${ }^{21}$ Segundo Krauss, a lista do que era suscetível de conduzir a esse prazer visual, ao qual Naville se referia, comportava ruas, quiosques, automóveis, o cinema e as fotografias.

Sabe-se que na história da fotografia sua clivagem como arte esbarrou na natureza técnica e reprodutível da imagem, que acabou por desencadear sua oscilação entre o valor da imagem técnica e o valor da imagem estética ao longo do século XX. Já em meados do século XIX, a fotografia colhia muitos adversários, sendo o mais conhecido deles o poeta e crítico de arte Charles Baudelaire, com sua severa crítica sobre a admissão da fotografia no Salão de Belas Artes de 1859. ${ }^{22}$ Dada a sua origem reprodutível, à semelhança de toda e qualquer mercadoria, cuja circulação é mediada pelo valor de troca, a fotografia como arte "nasceu sem aura" e demorou mais de um século para se recolocar no mundo como objeto artístico.

21 Pierre Naville apud Krauss, Rosalind. Fotografia e surrealismo. O fotográfico. Barcelona: Gustavo Gili, 2002, p. 114

22 Cf. Baudelaire, Charles. O público moderno e a fotografia (carta ao sr. diretor da Revue française sobre o Salão de 1859) [20 jun. 1859]. Tradução de Ronaldo Entler. Disponível em: < http://www.entler. com. br/textos/baudelairez.html>. Acesso em 10 jan. 2017. (Original em francês publicado em Études Photographiques, Paris: Société Française de Photographie, n. VI, maio 1999, pp. 22-32.) 
No livro A fotografia: entre documento e arte contemporânea, publicado em 2005 o historiador francês André Rouillé considera que, apesar da conciliação entre arte e fotografia ter sido anunciada pelas vanguardas no início do século XX, a partir principalmente do surrealismo, a "arte-fotografia" só conseguiu romper com o valor da obra fundado na originalidade quando a arte se viu completamente aderida ao mundo fantasmático do consumo cada vez mais saturado de imagens, fossem elas fotográficas, fílmicas ou televisivas. E mais ainda, é na década de 1980, segundo o autor, que a aliança entre elas se concretiza, e a fotografia se transforma definitivamente em matéria artística. ${ }^{23}$

Dito isso, para melhor se compreender a opção de Mano pela fotografia, justo no momento em que esta linguagem se reafirmava como arte e ao mesmo tempo se hibridizava com outros meios, é preciso retroceder brevemente aos idos de 1980 para entender até que ponto aquela geração de artistas, especialmente no Brasil, se apropriou da fotografia e a reformulou como expressão artística.

\section{FRICCุõES DA DÉCADA DE 1980}

Já amplamente familiarizado com a técnica, Mano passou a experimentar as possibilidades da fotografia como expressão, vivenciando ao mesmo tempo o embate dos anos 1980 sobre a sua natureza essencialmente documental, tanto no Brasil como no exterior, ao mesmo tempo que ela se abria a um novo hibridismo das linguagens artísticas, centrado na pesquisa sobre os meios (o que aparecerá, por exemplo, na expressão fotografia contaminada, que dá título à exposição organizada pelo curador Tadeu Chiarelli, em 1994). No âmbito paulista, a vocação documental da fotografia era ainda mais resistente, dada a presença marcante do fotojornalismo. Se, de um lado, a tradição paulista representava o valor da técnica aderido ao espelhamento do real e à sua qualidade reprodutível, de outro, a arte vivia seu retorno à figuração, que abriria um novo espaço para a fotografia, agora não mais como representação do real, mas como um outro real.

As inquietações de Mano acerca da linguagem fotográfica, elaboradas no horizonte das artes visuais, encontraram eco em dois episódios singulares ocorridos em São Paulo em meados dos anos 1980 e vivenciadas pelo artista: uma palestra de Cindy Sherman, em 1985; e uma palestra de Andreas Müller-Pohle, então editor da revista European Photopraphy, no ano seguinte, ambas realizadas no Museu da Imagem e do Som (MIS-SP). ${ }^{24}$ Os dois eventos corroboraram, segundo depoimento do artista, à reformulação das possibilidades da fotografia na arte contemporânea em âmbito local.

As primeiras séries fotográficas produzidas por Mano entre o final daqueles anos e o princípio da década de 1990 oscilaram entre retratos, autorretratos e paisagens. Partindo-se do pressuposto de que essas temáticas se fundam na tradição dos gêneros da pintura, pode-se inferir que através delas o artista buscou aproximar o fato fotográfico - como linguagem essencialmente documental e técnica - à esfera legitimada da arte. Porém, não se tratava de uma simples apropriação temática, mas de um deslocamento do seu conteúdo "artístico", reelaborado criticamente a partir da

24"[Andreas Müller-Pohle] deu uma palestra sobre a produção fotográica contemporânea realizada na Europa. E isso foi fundamental para eu deslocar o lugar de minha produção, no sentido de perceber ali o que pretendia enquanto expressão e trabalho. Foi muito marcante também pela reação da audiência, formada por uma turma mais ligada ao fotojornalismo, e balizada por experiências como as de Cartier-Bresson e Robert Capa. O contraste era tão forte que o Andreas teve que interromper o debate para perguntar se estava havendo algum problema de comunicação, já que falava em alemão. Disse ele: 'deve estar acontecendo algum problema de tradução, porque eu estou falando uma coisa e vocês estão me perguntando outra. Não me interessa o Cartier-Bresson Estou falando de outro momento da fotografa' Aquela incisão foi muito importante pra mim. [ Em 1987 viajei à Europa para encontrá ela se abria [ ] [No Brasil] naso tín mos revistas de arte ou de fotografia circulaça que com as a a as editoras tampouco fazlo min extraído da entrevista realizada em seu ateliê, São Paulo, 3 de agosto de 2015.) 


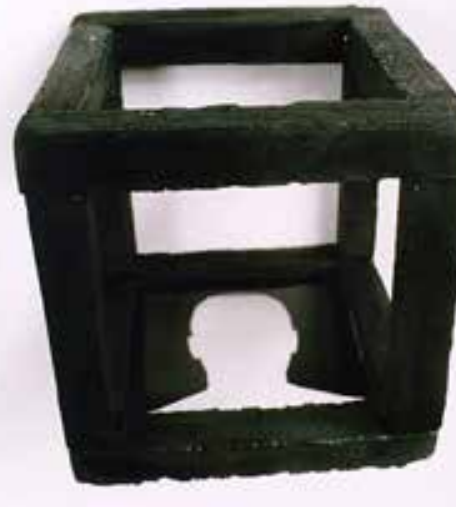

FIG. $1 \mathrm{~s} /$ título [contracampo], 1987 Fotografia, impressão pb em papel fibra, 140 × $210 \mathrm{~cm}$ (acima à esquerda)

\section{FIG. 2 s/ título, 1994} Instalação com fotografias impressas em papel fibra, vidro e PVC, diam.

$90 \mathrm{~cm} /$ cada (acima à direita)
(1) 19

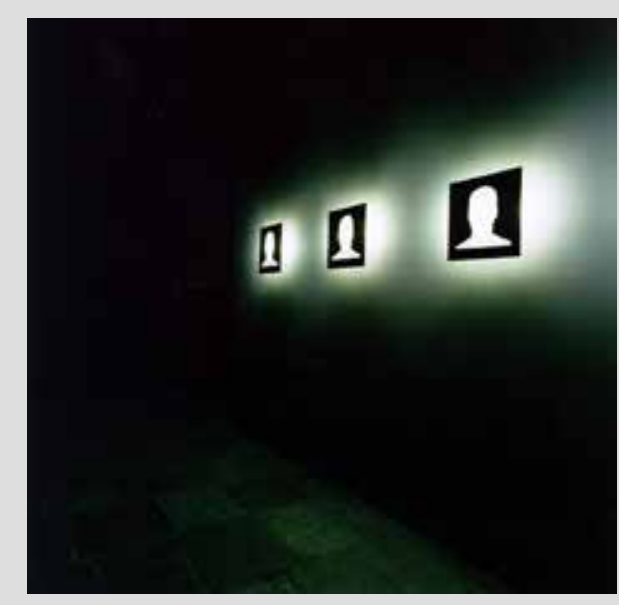

FIG. 3 corpus alienum, 1993/94 Kodalith e madeira, $8 \times 8 \times 8 \mathrm{~cm}$ (à esquerda)

FIG. 4 iminente circuito, 1995 Instalação com chapa de kodalith, acrílico, ferro, lâmpada fluorescente e sensor de presença, $240 \times 480 \times 850 \mathrm{~cm}$ (à direita) fotografia. Para além das temáticas de gênero, já nessas obras há uma certa resistência aos modos de operar da fotografia, percebidos: pela inversão do foco luminoso, a exemplo da obra s/título [contracampo] 25, de 1987 (fig. 1); no autorretrato produzido em 1994 (fig. 2), em que o artista "instala" a fotografia como objetos dispostos no chão; ou ainda nos autorretratos de silhueta (figs. 3 e 4) do mesmo período, em que o fato fotográfico deriva da ausência da imagem.

Além disso, essas imagens pressupunham uma ativação da obra pelo sujeito que as vê. Na foto de 1987, o foco luminoso do holofote se volta para o observador, como se este se colocasse no centro da obra. Na instalação com autorretratos de 1994, é preciso um descondicionamento do corpo para mergulhar nas imagens do rosto do artista, dispostas horizontalmente no chão como se repousassem placidamente em água. Da mesma forma, em iminente circuito (fig. 4), a obra só se completaria mediante a passagem do corpo do sujeito ao longo da instalação (na montagem realizada no Centro Cultural São Paulo, em 1995, Rubens criou um ambiente escuro dentro de uma sala com duas entradas, no qual as cinco silhuetas eram acionadas por meio de um circuito de sensores de presença).

Sobre a instalacão de 1995, a historiadora e crítica de arte Annateresa Fabris adiciona um dado importante à leitura dos trabalhos de Mano realizados no princípio dos anos 1990: a dimensão anônima do sujeito na metrópole, neste caso, do próprio artista:

As cinco cabeças idênticas que integram a instalação não podem ser consideradas retratos por não trazerem nenhuma marca fisionômica e não evocarem, portanto, um indivíduo. Por outro lado, por se configurarem apenas como contornos, não permitem determinar 25 Ao longo desta tese, todas as ocorrências de títulos de obras e séries concebidas por Rubens Mano
estão grafadas em caixa baixa, respeitando a normatização do artista. 
qualquer pertencimento social, remetendo à dimensão anônima da multidão urbana. ${ }^{26}$

Se na passagem dos anos 1980 aos 1990 seus trabalhos foram lidos pela crítica especializada na chave da fotografia (época em que participa de várias exposições coletivas na Galeria Fotoptica), em meados dos anos 1990 ele passa a integrar outros circuitos artísticos, não restritos ao fato fotográfico, ou mesmo aqueles onde o meio se "contagiou" por outras linguagens. Exemplo disso é a exposição Fotografia contaminada, realizada no Centro Cultural São Paulo, em 1994, com curadoria de Tadeu Chiarelli. Ainda no mesmo ano, Chiarelli publica um texto homônimo na revista mexicana Poliester, em que discorre sobre o termo:

O propósito deste texto é dar aspectos de uma outra fotografia realizada no país. Uma fotografia contaminada pelo olhar, pelo corpo, pela existência de seus autores e concebida como ponto de interesse entre as mais diversas modalidades artísticas, como o teatro, a literatura, a poesia e a própria fotografia tradicional. Assim, os autores aqui ci$\operatorname{tados}^{27}$ não seriam vistos propriamente como fotógrafos, mas como artistas que manipulam o processo e o registro fotográficos, contaminando-os com sentidos e práticas oriundas de suas vivências e do uso de outros meios expressivos. ${ }^{28}$

26 Fabris, Annateresa. Identidades virtuais: uma leitura do retrato fotográfico. Belo Horizonte: Editora UFMG, 2004, p. 67.

27 Os autores citados no texto são artistas que participaram da exposição de 1994, a saber: Valério Vieira, Anna Bella Geiger, Rosângela Rennó, Rubens Mano, Rosana Paulino, Lenora de Barros e Hudinilson Jr. Na entrevista de Rubens Mano realizada em 2015, o artista relembra igualmente alguns nomes que estavam interessados nessa contaminação dos meios e com os quais tinha uma interlocucão Além dos críticos Annateresa Fabris e Tadeu Chiarelli, ele inclui Rosângela Rennó, Rochelle Costi. Paula Trope, Bettina Musatti, Cris Bierre Tach, Everton Ballardin, Cao Cuimarães e El Sudback (Informaçōes obtidas durante entrevista realizada em seu ateliê, São Paulo 3 de agosto de 2015) (1 28 Chiarelli, Tadau. A fote enrevista realizada em seu ate ie, Sa, Paulo, 3 de agosto de 2015.) 28 Chiarli, Tadeu. A fotografia contaminada [1994]. Arte internacional brasleira. Sáo Paulo. Lemos-E-
Assim, apesar de eleger a fotografia como seu principal meio expressivo, pelo menos nestes primeiros anos da década de 1990, Rubens não se atém a ela como uma linguagem isolada, dentro do campo artístico, nem tampouco faz dela um fim em si mesma. Desde o início, o artista mostrou-se interessado em esgarçar os contornos do medium como imagem técnica e documental ao ampliar suas potencialidades como discurso visual para embaçar as fronteiras entre mundo sensível e mundo real, entre o artístico e o "não-artístico", entre espaço e imagem.

\section{A CIDADE E A CONSTRUCC̃̃O DE LUGARES}

Além da fotografia ter sido eleita pelo artista como a linguagem por meio da qual ele lê a cidade e elabora o real, ela significou uma espécie de porta de entrada para Rubens no mundo da arte. Contudo, já em meados dos anos 1990, são as questões que emergem da cidade e da vida urbana que o mobilizariam a produzir. Naquele momento, Mano é um desses artistas que se propuseram a investigar as contingências espaciais do viver paulistano, motivado pelas transformações do espaço urbano no tempo e pelas novas dinâmicas da vida urbana (a exemplo dos pares de contradições dispersão/concentração, anonimato/vigília, virtualidade/materialidade). As investigações que se processam aqui tomam o espaço da cidade como um constructo cultural, fruto da conjunção de diferentes extratos - espaciais e arquitetônicos, históricos e culturais, sociais e políticos.

Tal abordagem se aproxima da concepção sobre o espaço elaborada pelo geógrafo Milton Santos, referência constante no trabalho teórico de Rubens durante sua pesquisa de mestrado. Para assentar a sua prática, o artista lança mão do ponto de vista do geógrafo, que entende o espaço como a soma 
entre a sua materialidade e a vida que a anima. ${ }^{29}$ No livro $A$ natureza do espaço, o autor define o espaço como formado "de um lado, pelo resultado materia acumulado das ações humanas através do tempo, e, de outro lado, animado pelas ações atuais que hoje lhe atribuem um dinamismo e uma funcionalidade" ${ }^{30} \mathrm{E}$, como consequência, esse sistema de valores se transforma permanentemente.

Se considerarmos que o espaço, especialmente o espaço da cidade, é definido não apenas por suas características físicas, mas também pelo acúmulo de diversas temporalidades e relaçooes (desde afetivas até as de poder) estabelecidas no território, nos aproximaremos igualmente das considerações feitas por Marc Augé sobre o espaço e o lugar e as distinções entre os dois. Segundo o autor, o espaço "praticado" corresponde ao lugar antropológico, definido por três características comuns: identitários, como lugar de nascimento; relacionais, implicando relações e identidades partilhadas resultantes da ocupação de um lugar comum; e históricos, enquanto definido por uma estabilidade mínima. ${ }^{31}$ As três instâncias do lugar ajudarão a tecer as análises sobre as proposições de Mano, bem como de suas escolhas sobre os contextos em que as obras se dão.

Dos anos 1990 em diante, veremos como os modos operacionalizados por Rubens na percepção sobre o fato urbano pressupõem necessariamente esse espaço enquanto uma construção cultural, sendo impossível tomá-lo exclusivamente por sua fisicalidade. Como palco de relações sociais, o espaço urbano acumularia os dados fenomênico e informacional dessas relações espaciais, sociais, culturais e políticas, sobre as quais o trabalho se debruçará.

Neste período, o debate promovido pelas artes visuais estava impregnado da problemática contextual do lugar ao qual as obras se endereçavam. Diferentemente da perspectiva do site specifity dos anos 1960 e 1970, que teria en fatizado as condições físicas do lugar, na década de 1990 a abordagem crítica

29 Santos, Milton. A natureza do espaço: técnica e tempo, razão e emoção. São Paulo: Edusp, 2014, p. 62 30 lbidem, p. 106

31 Augé, op. cit., p. 52 . e cultural passa a implicar as relaçoes ensejadas no contexto, e que produziram socialmente o espaço da cidade. Tal como aponta o historiador da arte espanhol Jesús Carrillo:

A arte dos anos 1990 parece aprender a lição e tenta sair do cul de sac ao qual a reflexão modernista sobre o espaço em Tilted Arc havia chegado ${ }^{32}[. .$.$] . As obras de autores como Pierre Bourdieu ou Homi Bhabha$ demonstram as possibilidades de aplicação do paradigma espacialista à interpretação das relações humanas. Sua abordagem metafórica do conceito de espaço permite que eles passem do domínio da literatura e da arte para a interação social concreta e vice-versa. [...] Ambos tendem a considerar o espaço como uma construção cultural e a cultura como um conglomerado de relações espaciais, gerando-se uma espiral em que ambos os termos se sobrepõem e acabam se confundindo. ${ }^{33}$

No caso de Mano, a partir de meados de 1990, o artista incluirá em suas práticas a proposição de interferências e intervenções realizadas no fluxo da cidade, em edificaç̃es arquitetônicas e em espaços institucionais da arte, respectivamente. Tais proposições constituem ações pontuais e silenciosas que

32 A reflexão modernista a que o autor se refere diz respeito ao paradigma da indissociabilidade fisica da obra com o lugar para o qual foi concebida. O caso de Richard Serra ficou famoso por desencadear uma crise pública quanto à vocação e usos daquela praça, para qual a obra foi endereçada a ponto de ele ter que retirar a obra do lugar, o que implicou a sua imediata destruição, física e simbólica.

33 "El arte de los 1990 parece aprender la lección e intenta salir del culdesac al que había llegado la reflexión modernista sobre el espacio en Tilted Arc (...). La obra de autores como Pierre Bourdieu o Homi Bhabha demuestran las posibilidades de la aplicación del paradigma espacialista a la interpretación de las relaciones humanas Su aproximación mecáórica al concepto de espacio les permite saltar del a las relacio litera hater del consid da licha consicer esparias. nes espaciales, generándose una espiral en la que anbos terminos se solapan y acaban confundiencrítico, esfera publica e y acción directa. Salamanca: Ediciones Universidad de Salamanca, 2001, p. 113. 
os questionamentos acerca do projeto moderno como ideologia planificadora

e abstratizante e interrogações sobre que tipo de vida urbana isso teria produzido. De modo geral, e atravessando as décadas de 1990 e 2000, destaca-se ainda a maneira como o artista tangencia a relação entre o (espaço) público e o (espaço) privado, evidenciado tanto nos limites físicos estabelecidos na cidade e nas relações nela engendradas quanto no relacionamento e estratégias institucionais do meio artístico com seus públicos.

Esboçadas as considerações iniciais acerca da obra de Rubens Mano, o estudo das obras do artista se desenvolveu em dois caminhos principais: o dos pressupostos teóricos para uma aproximação tanto da problemática urbana como das relações estabelecidas entre arte e cidade na história da arte mais recente (especialmente a paulistana), apresentados no Capítulo 1; e outro, do estudo aprofundado das obras, sua historiografia, fortuna crítica e contextos, desenvolvido nos três capítulos subsequentes. No decorrer da pesquisa, ambos seguiram juntos e se interpenetraram. Esse cruzamento será percebido na tese não só no encadeamento dos quatro capítulos, como também na construção de atravessamentos já dentro das leituras de obras, que discorrem sobre certos contextos da produção de arte contemporânea em geral e sobre assuntos implicados nas obras de Mano, e que ajudam a contextualizar os trabalhos ao longo das leituras, buscando expor qual era o debate de fundo naquelas ocasiões. 
O envolvimento mais direto com a produção de Rubens Mano ao longo da pesquisa do doutorado sinalizou a importância de se averiguar três principais vetores, que surgiram das primeiras leituras sobre o conjunto de obras selecionadas, e que pareceram fundamentais para o tipo de arte que se quer tratar aqui, constituída em meados dos anos 1990 no bojo das grandes cidades, especialmente São Paulo.

Primeiramente, destaca-se a centralidade que a cidade ganha nesse período, e que será perseguida a partir de suas origens na problemática urbana apontada pelo filósofo francês Henri Lefèbvre na transição entre as décadas de 1960 e 1970. À inflexão histórica das cidades verificada no período corresponde um movimento de deslocamento da arte em direção a práticas interessadas no contexto e que repuseram o problema do lugar no debate contemporâneo. Como veremos, o interesse de certos artistas em perseguir as qualidades específicas do lugar esteve em estreito diálogo com as considerações tecidas sobre o espaço praticado, em Michel de Certeau, e sobre o lugar antropológico, em Marc Augé.

Além disso, o métier artístico dos anos 1990, especialmente paulistano, constituiu-se, dentre outras coisas, a partir de uma tendência à hibridização dos meios verificada na década anterior; naqueles anos, a volta à valorização dos meios e a mistura de estilos teve um sentido libertário em relação ao rigor de certas normativas modernas ainda vigentes, de certos conceitualismos e do engajamento crítico-político dos anos 1970.

Procurou-se, então, compreender a partir das obras de Rubens Mano - por meio dos estudos desenvolvidos nos capítulos 2, 3 e 4, os quais constituem o corpus principal da tese - como a associação do urbano e da produção do espaço, de um lado, e o hibridismo dos meios e a abordagem contextualista da arte contemporânea, de outro, compuseram de modo singular as proposições do artista abordadas nesta tese. 
A arte sempre foi fruto de uma consciência da civilização que constrói a cidade. Segundo Ciulio Carlo Argan, ela não é apenas uma atividade urbana inerente, mas constitutiva da cidade. ${ }^{34}$ Tomando a perspectiva do historiador italiano, o final dos anos 1960 foi marcado por uma inflexão na história da cidade que teve ecos e reações na produção de arte do período. A partir dali, a cidade foi abarcada como entidade real, tangível, produto de relações culturais, abandonando sua formulação projetiva. É justamente na passagem dos anos 1960 aos 1970 que origina-se a perspectiva artística que toma o espaço da cidade como um constructo cultural, numa trama complexa que envolve sua constituição física, seus aspectos construtivos e as relações sociais e de poder ali engendradas. Nesse sentido, valeria apena aqui investigar brevemente como se deu essa inflexão na história da cidade neste período e por que a problemática urbana ganhou importância a partir de então.

A generalização do fenômeno urbano induzida pela industrialização cujo processo teve início no final do século XIX e caracterizou a sociedade moderna - foi determinante para a mudança ocorrida nas cidades e nas relações sociais na transição entre as décadas de 1960 e 1970. O filósofo Henri Lefèbvre identifica no final de 1960 o surgimento da problemática urbana, que marcaria a grande inflexão na história, ${ }^{35}$ pela qual a lógica da produção industrial entrou em colapso e o urbano passou a estruturar a nova ordem. A crise da racionalidade industrial, traduzida pela superação do mundo quantitativo com base na produção, cedeu lugar à sociedade de consumo; por sua vez, essa nova sociedade, da reprodução, se estabeleceu sob a égide da moeda de troca e da acumulação, onde a questão central já não é mais a produção industrial, mas a produção de espaço, por meio do qual o capital se reproduz.

34 Argan, Giulio Carlo. História da arte como história da cidade. São Paulo: Martins Fontes, 1998, p. 43. 35 Cf. Lefèbvre, Henri. O fim da história. Lisboa: Dom Quixote, 1987 de industrialização (modelo, planificação, programação) ao período no qual a problemática urbana prevalecerá decisivamente, em que a busca das soluções e das modalidades próprias à sociedade urbana passará ao primeiro plano. ${ }^{36}$

É a partir dessa nova sociedade que o urbano ganha importância e a produção do espaço - que envolve o cotidiano - emerge como questão estrutural da sociabilidade nas grandes cidades. É sabido que todo modo de produção (econômica) produz um espaço. Até os anos 1960, os sistemas de produção coincidiam com os sistemas urbanos no território. A inflexão verificada em meados da década foi marcada pelo que Lefèbvre nomeou como um duplo processo de industrialização-urbanização das cidades. Esse duplo processo se explicaria pelo fato da industrialização ter forçado a implosão da cidade (a perda da sua centralidade entendida como o núcleo espacial onde se dá o encontro e se realiza plenamente o sentido público da cidade); e, esta, incapaz de se urbanizar na mesma velocidade, dispersou-se no território, explodindo em subúrbios "desurbanizados". O filósofo nomeou o período da história da cidade ${ }^{37}$ que se inicia em meados da década como ponto crítico, processo que se desdobra até hoje e que vem sendo discutido com frequência por urbanistas, arquitetos, artistas, historiadores e críticos de arte. Pode-se dizer que o ponto crítico lefebvriano corresponde à instauração da dialética entre a falência da práxis moderna e a nova condição contemporânea da cidade.

A perda das centralidades, sinalizada por Lefèbvre no período, acarretou a perda potencial de reunião, encontros e conflitos no substrato da cidade,

36 Lefèbvre, Henri. A revolução urbana. Belo Horizonte: Editora UFMG, 1999, p. 19

37 Para Lefèbvre, a cidade se desdobrou nos seguintes períodos históricos: a cidade política, grega por excelência; a cidade comercial, da Idade Média; a cidade industrial, ou moderna; e a cidade atual, que tem origem no ponto crítico. Cf. Lefèbvre, Henri. O direitoà cidade. São Paulo: Editora Documentos, 1969. 
tendendo a uma desintegração das práticas sociais e políticas do sujeito; o que, de alguma forma, se desdobrou numa certa nostalgia do espaço público verificada no espírito das grandes cidades a partir dos anos 1990, definidas estas pela fragmentação e pela dispersão.

Num cenário de crise da racionalidade industrial e de generalização do fenômeno urbano, uma nova espécie de sociedade passa a ser engendrada, a sociedade urbana - variavelmente descrita como sociedade pós-industrial ${ }^{38}$ ou sociedade de consumo. Analogamente ao filósofo francês, Fredric Jameson identifica no período a emergência de uma sociedade pós-moderna, cujos traços demarcam uma ruptura radical com a sociedade do pré-guerra, na qual o modernismo ainda era uma força clandestina.

Novos tipos de consumo, obsolescência programada, um ritmo ainda mais rápido de mudanças na moda e no styling, a penetração da propaganda, da televisão e dos meios de comunicação em grau até agora sem precedentes e permeando a sociedade inteira, a substituição do velho conflito cidade e campo, centro e província, pela terceirização e pela padronização universal, o crescimento das grandes redes de autoestradas e o advento da cultura do automóvel. ${ }^{39}$

Para Otília Arantes, o período vivera o que a filósofa alarmou como "urbanismo em fim de linha", ${ }^{40}$ representado pela falência da utopia moderna, que almejara a uma racionalidade da cidade funcional para conter sua explosão. À exemplo da capital Brasília, a história demonstrou que a urbanística mo-

38 Parte da literatura sobre a cidade também usa o termo "cidade pós-industrial" a partir do final dos anos 1960 . O termo é empregado sob três perspectivas: para designar o que decorre do esgotamento da cidade moderna, quando a lógica industrial é substituída por uma cidade terciária, cujas trocas são cada vez mais virtualizadas; para qualificar o processo de desurbanização, em que a cidade desaparece em função dos diferentes regimes de temporalidade das novas tecnologias; ou ainda da caracterizar a sociedade do consumo, propriamente dita, no contexto da pós-modernidade.

39 Jameson, op. cit., 1985, p. 26.

40 Cf. Arantes, op. cit., 2001 derna do planejamento e da racionalidade foi incapaz de "domesticar" a vida urbana e pensá-la em sua multiplicidade.

O panorama que se desenha no despontar da década de 1970 poderia ser ilustrado como a imagem de uma grande cidade "urbanizada", onde o espaço público perdeu o sentido nas cidades; onde o consumo determina os modos de usá-la, no modelo de felicidade; onde a ideologia do urbanismo moderno implementou espaços homogêneos e sem qualidade, tendendo a anular as diferenças; onde promoveu-se a dispersão urbana e a segregação espacial num modelo de crescimento e progresso; onde o carro tem mais valor que o pedestre; e assim por diante.

De modo geral, é igualmente na transição entre as duas décadas que as mudanças evidenciadas na cidade, da produção social do espaço e da vida urbana, passam a ser enfrentadas mais diretamente pelos artistas. Nos países desenvolvidos, a arte se viu cada vez mais desafiada pela nova sociabilidade, cuja dinâmica reagia às tendências funcionais da ordenação da vida urbana (a perda da identidade dos espaços da cidade), às novas tecnologias oferecidas pela ciência e pela indústria (mobilidade e virtualidade), à exacerbação do aparato visual e informacional da cultura de massa, dentre outros aspectos. No interior do circuito internacional consolidado, a arte passou a questionar o caráter objetual da obra como mercadoria, numa tendência à sua desmaterialização e à valorização dos processos, ao mesmo tempo que buscou alargar o seu lócus especializado, abrindo-se às contingências do espaço real no dia a dia da cidade. Elisabetta Andreoli e Laymert Garcia dos Santos lembram que “desde os anos 70 há artistas adotando uma série de estratégias para sair da galeria de arte: enquanto uns também deixaram a cidade [...], outros consideraram o espaço urbano como um lócus privilegiado de intervenção". ${ }^{41}$

A vida cotidiana produzida pela modernidade mobilizara uma profusão de reações à homogeneização dos espaços da cidade fruto da racionalidade e da "ideologia do plano", expressa inclusive na bandeira das minorias (de

41 Andreoli e Santos, op. cit., p. 285 
gênero, raça ou opção sexual). O urbanista Bernardo Secchi defende que os movimentos revolucionários decantados de Maio de 1968, fato que te ria marcado o fim da modernidade (entendida como sociedade moderna por excelência), representavam um indivíduo sensitivo que passou a usar o corpo como agente mediador de cidade, em busca de suas liberdades individuais, dos direitos das minorias e da diversidade. ${ }^{42}$

Nesse cenário, surge uma diversidade de modos de atuar, elaborar e formalizar um trabalho, uma proposição, uma ação... que passam a problematizar o urbano e suas formas de existência. Eles vão desde atuações disruptivas que promovem certos desvios descondicionantes no cotidiano da cidade e nos modos de habitá-la, como é o caso da deriva situacionista; passando pelo retorno à natureza na busca de uma nova relação do sujeito com ela, transpostas e publicizadas pela fotografia, a exemplo da land art até a formulação da vida prosaica do consumo, do massmedia e sua avalanche de imagens produzidas, em poéticas que se utilizaram da sintaxe pop; dentre outras tendências.

As manifestações artísticas produzidas em campo ampliado implicaram novas noções de espaço, tempo, escala e grandeza dos trabalhos, recepção e participação, linguagem e conceituação, objetualidade e projeto, criticismo e ativismo, dentre outras.

\section{PRÁTICAS CONTEXTUAIS: 0 ESPAC̣O E 0 LUGAR}

O advento de uma sociedade urbana por excelência, teorizada por Henri Lefèbvre, resultou, como visto, de um duplo processo de implosão-explosão das cidades em meados dos anos 1960. Uma das consequências apontadas pelo filósofo foi a perda das centralidades, que tendeu a ocasionar a desestruturação das práticas sociais e políticas ensejadas no espaço urbano. Nos domínios da arte, a crise da forma moderna - caracterizada por uma arte autônoma e "desinteressada" - trouxe, entre outros aspectos, um interesse renovado pelo meio urbano, despertado no final dos anos 1960. O cenário artístico do período viu desabrochar uma multiplicidade de iniciativas independentes, fora do lócus institucional e das trocas mercantis, que esgarçaram os contornos de atuação da arte ao abrirem-se à experiência da cidade - traduzida, grosso modo, no desejo de uma imersão poética no ambiente social da vida urbana. Houve uma proliferação de trabalhos realizados em determinados contextos, numa mútua impregnação com o meio a partir do e no qual se realiza - sendo o site specific work uma de suas expressões, surgida no bojo da produção minimalista.

A reposição do problema do lugar nos anos 1960 remete a algo que a arte de matriz ocidental europeia, especialmente a escultura, tinha perseguido desde o século XIX, quando as obras perderam seus significados e sua identidade na cidade na direção da autonomia da forma. O enrijecimento da autonomia moderna acabou levando à autorreferencialidade da obra, voltada a questões da pura visualidade, bem como a uma ambição universalista (a exemplo da tendência abstratizante).

Nas palavras do crítico de arte norte-americano Douglas Crimp,

O idealismo da arte moderna, na qual o objeto de arte em sie por si mesmo era visto como tendo um significado fixo e trans-histórico, determinava a ausência de lugar do objeto, seu pertencimento a nenhum lugar em particular, um não-lugar que na verdade era um museu - o museu 
real e o museu enquanto uma representação do sistema institucional de circulação, que inclui também o estúdio do artista, a galeria comercial, a casa do colecionador, o jardim-escultura, a praça pública, o saguão da matriz das corporações, a cúpula do banco...43

As novas práticas ensejadas em meados de 1960 passaram a reivindicar novamente a especificidade do lugar de sua realização, opondo-se a tal idealismo moderno e buscando pertencer a um espaço específico.

De acordo com o historiador da arte Hal Foster, a ausência do lugar, típica das esculturas abstratas, foi refutada pela minimal art, bem como qualquer resíduo representacional de tradição clássica. No caso da escultura, esta passou a se realizar não mais como ato de agregar um objeto a um espaço, mas como uma forma de se constituir um lugar. ${ }^{44}$

Com o minimalismo, a escultura não está mais isolada, sobre um pedestal ou como arte pura, mas é reposicionada em meio a objetos e redefinida em termos de lugar. Nessa transformação, o observador, recusado o espaço seguro e soberano da arte formal, é remetido ao aqui e agora; e ao invés de examinar a superfície de um trabalho para um mapeamento topográfico das propriedades do seu meio, é instigado a explorar as consequências perceptivas de uma intervenção particular num lugar determinado. 45

É no esteio dessa produção que se verifica o que a crítica de arte norte-americana Miwon Kwon denominou como primeira ocorrência da poética do site specificity, cujas práticas pressupõem trabalhar com os dados circunstanciais

43 Crimp, Douglas. Sobre as ruínas do museu. São Paulo: Martins Fontes, 2005, p. 18.

44 Cf. Foster, Hal. O ponto crucial do minimalismo. O retorno do real: a vanguarda no final do século XX. São Paulo: Cosac Naify, 2014, pp. 51-78.

45 Ibidem, p. 53. do lugar. ${ }^{46}$ Essa operação também transformou a relação entre objeto de arte e observador; o público foi conduzido a explorar outros pontos de vista de uma intervenção em particular num dado local, a exemplo dos specific objects de Donald Judd (1928-1994) e das formas unitárias de Robert Morris (1931-).

A problemática do lugar reivindicada pela arte encontrou reverberações nos escritos do historiador francês Michel de Certeau, cujo principal interesse assenta-se no universo das práticas sociais contemporâneas e nas circunstâncias sociais de troca que são impressas no território. Por meio de "caminhadas pela cidade”, expressão que dá nome a um dos capítulos desenhados por Certeau no livro $A$ invenção do cotidiano, ${ }^{47} \mathrm{o}$ autor nos conduz a uma análise minuciosa do território urbano, cujas trocas sociais são responsáveis pelas alterações das noções de espaço e lugar e que, por conseguinte, conferem a elas existências específicas, temporalizadas e fragmentadas.

A "cidade" instaurada pelo discurso utópico e urbanístico é definida pela possibilidade de uma tríplice operação: 1. a produção de um espaço próprio: a organização racional deve recalcar todas as poluições físicas, mentais ou políticas que a comprometeriam; 2. estabelecer um não-tempo ou um sistema sincrônico, para substituir as resistências inapreensíveis e teimosas das tradições [...]; 3. a criação de um sujeito universal e anônimo que é a própria cidade. ${ }^{48}$

A partir de uma análise da cidade moderna, funcional, o historiador vai contrapor as noções de lugar e espaço:

Um lugar é a ordem segundo a qual se distribuem elementos nas relações de coexistência. [...] é uma configuração instantânea de po-

46 Kwon, Miwon. One Place After Another: Site Specific Art and the Locational Identity. Cambridge: The MIT Press, 2002, p. 11

47 Certeau, Michel de. Caminhadas pela cidade (Capítulo VIII). A invencão do cotidiano, op. cit. pp. 169-191. 48 Ibidem, pp. 172-173. 
sições. Implica uma indicação de estabilidade. [...] Espaço é o efeito produzido pelas operações que o orientam, o circunstanciam, o temporalizam. ${ }^{49}$

O espaço, assim, é definido pelo autor como um lugar praticado, o qual remeteria à ideia de temporalidade e sobreposição histórica, em relação à ideia de lugar considerado simplesmente em sua dimensão física, algo estável e não identitário. Para De Certeau, a busca pela constituição do lugar passaria pela busca por uma identidade histórica, um certo sentido de pertencimento e apropriação do real. A partir de meados da década de 1960, as novas manifestações artísticas site-oriented, que consideravam a especificidade de um dado lugar, envolveram ações como apropriar-se, inserir-se numa rede relacional, situar-se no tempo, fazendo da obra algo circunstancial, inseparável do contexto.

As décadas de 1960 e 1970 estão repletas de práticas artísticas que atentaram para o problema da especificidade do lugar na cidade e buscaram ressignificar o contexto urbano. Os monumentos de Passaic (1967), de Robert Smithson (1938-1973), e Delirium ambulatório (1978-1980), de Hélio Oiticica (1937-1980), são exemplos da busca por uma experiência significativa do lugar. Em ambos os casos, os artistas traduziram suas experiências vivenciais sobre o território sob formulações de outras ordens que não a objetual - quer via documentação fotográfica e relatos de passagem, quer sob novas formas de (re) apresentação desses lugares sociais e urbanos como performance. A originalidade dos trabalhos residira em se constituírem como "processo", uma experiência de espaço que se apresenta por meio de uma prática do meio urbano formalizado.

Os monumentos de Passaic é um relato de passeio de Smithson pelos subúrbios de Nova Jersey, ao longo do Rio Passaic, sua terra natal. Nele, o artista "desenhou" quadro a quadro, numa espécie de construção cinematográfica do lugar, suas impressões como pedestre sobre a paisagem e o ambiente

49 Certeau, Michel de. Relatos de espaço (Capítulo IX). A invenção do cotidiano, op. cit., pp. 201-202. de um sítio urbano em ruínas - descritos como "monumentos": uma ponte sobre o rio Passaic que ligava Bergen County e Passaic County; suportes de concreto que sustentavam a parte inferior de uma nova rodovia em construção; uma draga com um longo cano acoplado no meio do River Drive; uma cratera artificial que continha um tanque de água límpida, de onde saiam seis canos largos esguichando a água do tanque para o rio, uma espécie de fonte monumental. Os elementos monumentais apresentados por Smithson estavam "enquadrados" por uma placa de obras do Departamento Rodoviário Estadual de Nova Jersey, onde lia-se a seguinte frase: "suas taxas de pedágio em ação".

Esse panorama zero parecia conter ruínas às avessas, isto é, todas as novas edificações que eventualmente ainda seriam construídas. Trata-se do oposto da "ruína romântica" porque as edificações não desmoronam em ruínas depois de serem construídas, mas se erguem em ruínas antes mesmo de serem construídas. Essa mise-en-scène antirromântica sugere a desacreditada ideia de tempo e muitas outras coisas "ultrapassadas". Mas os subúrbios existem sem passado racional e sem os "grandes eventos" da história. Ah, talvez haja umas poucas estátuas, uma lenda e umas quinquilharias, mas não há nenhum passado - apenas o que passa para o futuro. ${ }^{50}$

O relato de viagem de Smithson, acompanhado de uma série de 24 fotografias em preto e branco, foi publicado na edição n. 48 da revista Artforum, em dezembro de 1967. Diferentemente das práticas até então estabelecidas, o resultado aqui não pressupôs uma atuação física e temporal no meio urbano, mas ampliou sua formalização numa multiplicidade de linguagens - textuais, fotográficas, documentais, que por sua vez constituíram um novo site

50 Smithson, Robert. Um passeio pelos monumentos de Passaic, Nova Jersey [1967]. Arte\&Ensaios, n. 19,2009, p. 165 
(o non-site)..$^{51} \mathrm{O}$ caderno de viagem do artista traz sua versão sobre o significado dos subúrbios norte-americanos produzidos pela industrialização - o que Lefèbvre apontara como a relação campo-cidade a partir da centralidade urbana (neste caso, entre Passaic e Nova York) -, e como o duplo processo in dustrialização-urbanização produziu o negativo de cidade, edificada em sua gênese como ruína. Esse par antagônico seria fruto de uma mesma gênese, a que Smithson chamaria de entropia. Aos olhos do artista, aquelas ruínas se apresentavam como futuros abandonados: "estou convencido de que o futuro está perdido em algum lugar nos depósitos de lixo do passado não histórico; está nos jornais de ontem, nos anúncios insípidos de filmes de ficção científica, no falso espelho de nossos sonhos rejeitados". ${ }^{52}$

A paisagem que Smithson constrói a partir da experiência de Passaic pode ser tomada como uma operação artística-crítica sobre as heranças do mundo moderno industrial e como elas podem ser apreendidas simbolicamente em sua "beleza", reconstruídas pela experiência como monumentos Invertendo a sensibilidade romântica sobre a ideia de ruína, pela qual o tempo se encarrega de construí-la, o artista toma a paisagem suburbana industrial como negativo de cidade, no qual os elementos prosaicos que sustentam o projeto de modernização do local passam a ser personagens de um filme de ficção científica roteirizado pelo artista.

No Rio de Janeiro, no final dos anos 1970, Hélio Oiticica promove algumas manifestações de rua, sob o título de Delirium ambulatório, as quais exprimem sua postura totalmente disponível à imprevisibilidade do caminhar, quer este seja pelos morros e favelas, quer pela cidade formal, ${ }^{53}$ onde $\mathrm{o}$ acon-

51 Smithson elaborou o conceito de non-site a partir de sua própria prática artística, vindo da necessidade de transpor seus projetos de terra para espaços fechados (galerias). O artista procurou criar extensões entre o lugar no qual se situa a obra e os elementos (mapas, desenhos, fotografias, filmes, anotaçōes ) que deslocados do contexto original a completam e possibilitam sua extens̃̃o espaçotempora A obra passa a ser tanto a intervença na paisagm (site) como o conjunto de elespaçoque a reconstródispostos na gateria (nor-sit). 52 Smithson, op. cit., p. 167.

53 Favaretto, Celso. A invenção de Hélio Oiticica. São Paulo: Edusp/Fapesp, 200o, p. 221. tecimento estético se colocou à mercê do outro e da cidade. Oiticica realiza três exercícios de "delírio ambulatório": em 1978, durante o evento Mitos vadios, organizado por Ivald Granato num estacionamento da rua Augusta, como uma paródia às bienais; em 1979, no Caju, nomeado como Kleemania ou Devolver a terra à terra; e, em 1980, no morro da Mangueira, intitulado Esquenta pro Carnaval.

Sobre a "performance" que Oiticica realizou em São Paulo, em 1978, durante o evento Mitos vadios, o crítico de arte Frederico Morais escreve:

Oiticica trouxe para São Paulo, seus "fragmentos-tokens" (asfalto da avenida Presidente Vargas, terra do morro da Mangueira, água da praia de Ipanema, objetos de bazares da "rua Larga") e, como estímulo ao seu deambular crítico-criativo, vestiu-se com sapato prateado de salto alto, camiseta dos Rolling Stones debaixo de um blusão cor-de-rosa, sunga, óculos de mergulhador e peruca feminina. Foi assim, com essas roupas e tokens cariocas, que se intrometeu no evento paulista, pura vadiagem artística. ${ }^{54}$

Se os penetráveis concebidos nos anos anteriores, tais como Tropicália e Éden, sintetizaram a sua experiência do vivido nas ruas do Rio de Janeiro, transposta ao observador-participante como um percurso psicossensorial (impregnados de sensações visuais, táteis e sonoras), os acontecimentos poético-urbanos do final da década - seja pelas ruas dos morros ou da cidade formal - não propõem nada, segundo o crítico de arte Celso Favaretto, a não ser uma "pura disponibilidade criadora”, totalmente disponível à imprevisibilidade. ${ }^{55}$

Sobre eles, Oiticica diz: 
sintetizo na ideia do Delírio ambulatório. O negócio de andar pelas ruas é uma coisa que, a meu ver, me alimenta muito e eu encontro. [...] O delírio ambulatório é um delírio concreto. Quando eu ando ou proponho que as pessoas andem dentro de um Penetrável com areia pedrinhas, estou sintetizando a minha experiência da descoberta da rua através do andar, do espaço urbano através do detalhe do andar, do detalhe síntese do andar. [...] Todos os espaços do Rio de Janeiro têm pra mim um significado concreto e vivo, um significado que gera essa coisa que eu chamo de delírio concreto. ${ }^{56}$

A reposição do problema do lugar implicava igualmente a retomada de vínculos imediatos com a vida. O desejo de vivenciar os espaços da cidade, de experimentar o vivido na cidade, parece ser um dos aportes mais potentes da atitude poética-crítica de Oiticica no final da década. É a partir da posição totalmente disponível à experiência do lugar como lugar praticado (tomando a cidade na sua dimensão social, das relações e da reunião) que o artista ativa as potencialidades desse espaço social. Segundo De Certeau, a figura do pedestre seria a única posição possível para transformar a rua, concebida geometricamente pelo urbanismo, em espaço praticado. ${ }^{57}$

A invenção do caminhar na cidade como prática desenvolvida por vários $\operatorname{artistas}^{58}$ adquiriu sentidos diversos - fosse para reestabelecer o sentido de pertencimento a certos lugares em busca de uma nova identidade do sujeito e do coletivo, tal como nas práticas de deriva desenvolvidas pelos situacionistas; fosse para deflagrar a experiência urbana em ações que flertam com o ativismo político, tal como aparece em trabalhos de Gordon Matta-Clark. Paralelamente, a reconstrução desses andarilhos instaura um novo conflito, da ordem da formalização dos trabalhos: como transformar a experiência em

56 Hélio Oiticica apud Favaretto, op. cit., p. 224

57 Certeau, op. cit., p. 202

A patica estética do caminhar será abordada mais detidamente no Capítulo 2 desta tese, à luz da

concepção de nomadismo urbano elaborada pelo sociólogo francês Michel Maffesoli. obra? Para muitos deles, a ação era mais importante que o registro.

Antes mesmo da geração 1960, um grupo de escritos e artistas reunidos na França passou a praticar caminhadas na cidade como método para reinventá-las. O movimento situacionista, encabeçado por Guy Debord, tinha como fundamentos estéticos três estratégias criativas básicas: o détournement, a psicogeografia e o urbanismo unitário. A prática da deriva ${ }^{59}$ se apresenta como uma técnica de passagem rápida por ambientes variados, e estava ligada ao reconhecimento de efeitos "psicogeográficos" (manifestados pela ação direta do meio geográfico sobre a afetividade) e à afirmação de um comportamento lúdico-construtivo, oposto às tradicionais noções de viagem e passeio.

De início, o grupo propôs uma arte diretamente ligada à vida; porém, aos poucos perceberam que essa "arte integral" seria basicamente urbana e deveria estar em relação direta com a cidade e com a vida urbana em geral.

Em um primeiro momento, essas investigações propriamente urbanas se referiam à experiência da cidade existente - através de novos procedimentos e práticas: psicogeografia e derivas - mas também à utilização dessas experiências como base para uma proposta de cidade situacionista. [...] À medida que os situacionistas afinavam suas experiências urbanas, eles abandonaram a ideia de propor cidades reais e passaram à crítica feroz contra o urbanismo e o planejamento em geral. [...] Qualquer construção dependeria da participação ativa dos cidadãos, o que só seria possível por meio de uma verdadeira revolução da vida cotidiana. ${ }^{60}$

Para os situacionistas, o ato de andar se colocava como um ato social e político, em potencial. De acordo com o pensamento de Lefèbvre sobre o valor

59 A Teoria da Deriva foi lançada pelos situacionistas em 1958, por meio da qual o grupo estabeleceu as bases da nova prática. Cf. Debord, Guy. Teoria da deriva. Jacques, Paola Berenstein (org.). Apologia da deriva: escritos situacionistas sobre a cidade. Rio de Janeiro: Casa da Palavra, 2003, pp. 87-91. 60 Jacques, Paola Berenstein. Apresentação. Jacques (org.), op. cit., p. 19. 
de uso da cidade, era nas ruas, nos possíveis encontros promovidos pelas centralidades da cidade, que as pessoas se transformariam efetivamente em público. Assim, nada mais natural que os fundamentos situacionistas de uma crítica à condição urbana da época provesse em boa medida dos cursos ministrados por Lefèbvre na universidade, frequentados por vários membros do grupo de Nanterre. ${ }^{61}$

Como coloca a escritora estadunidense Rebecca Solnit, "andar é apenas o início da cidadania, mas através desse ato o cidadão conhece sua cidade e outros cidadãos, e passa a habitar realmente a cidade, e não uma pequena parte privatizada dela". ${ }^{62}$

A cidade não se colocava apenas como território a ser reconquistado criativamente, mas se mostrava também como substrato no qual se materializam relações sociais e culturais. Agir no cerne das relações sociais produzidas pelo cotidiano da vida urbana e recriá-las poeticamente eram pretensões de vários artistas do período. No início dos anos 1970, ações efêmeras e práticas performativas contagiaram o público das ruas do sul de Manhattan. As performances de Trisha Brown (1936-2017) realizadas no entorno da Wooster St., tais como Man Walking Down the Side of a Building (1970) desafiavam os deslocamentos pré-estabelecidos na cidade à medida que os corpos se apoiavam em estruturas edificadas do bairro (empenas, caixas d'agua, telhados...) para se deslocar em direções e sentidos inusitados, contrariando inclusive a gravidade desses mesmos corpos.

Outro artista, parceiro de Trisha, que movimentou as ruas nova-iorquinas foi Matta-Clark, ao propor uma série de projetos intitulados "city-related works", que inclui Pig Roast (1971), um churrasco de porco embaixo da ponte do Brooklin oferecido à população de rua do entorno; e Fresh Air Cart (1972), um carrinho com dispositivo de oxigênio pelo qual distribuía "ar" aos transeuntes das calçadas entupidas da Wall Street, nas proximidades da Times

61 Sevcenko, Nicolau. Configurando os anos 70: a imaginação no poder e a arte nas ruas. Anos 70 trajetórias. São Paulo: Itaú Cultural//luminuras, 2005, p. 21.

62 Solnit, Rebecca. Wanderlust: A History of Walking. Nova York: Penguin, 2001, p. 176
Square. ${ }^{63}$ Tais experiências também reverberaram na criação do restaurante Food, em 1971, na Prince St. De acordo com a curadora Pamela Lee, havia um profundo ethos social e comunitário na jovem geração de artistas instalada no Soho à época. ${ }^{64} \mathrm{O}$ esforço colaborativo do restaurante, entre Matta-Clark e colegas do bairro, pressupunha uma dimensão social ao prover empregos e espaço de encontro para artistas..$^{65}$

Nos anos seguintes, o modo performativo dos trabalhos city-related de Matta-Clark promovidos nas ruas se uniram a ações de extração de partes de edificações, inaugurando uma nova prática na obra do artista, a exemplo de Bronx Floors (1972), Pier In/Out (1973) e Splitting (1974), que enfrentaram a deterioracão de construç̃es abandonadas e espaços baldios e a gentrificação de bairros inteiros promovida pela reurbanização da cidade no período. Esse enfrentamento das questões urbanas decantadas da modernização da cidade, expresso no interesse do artista por lugares urbanos residuais, vai encontrar um panorama análogo nos anos 1990, ao longo do qual o artista Rubens Mano também reagirá diante das transformações da cidade de São Paulo.

63Jenkins, Bruce. Gordon Matta-Clark: Conical Intersect. Londres: Afterall, 2011, p. 52

64 Lee, Pamela. Object to Be Destroyed: The Work of Gordon Matta-Clark. Cambridge: The Mit Press, 2000, p. 68.

650 "culinary performance" promovido no restaurante Food em 1971 é um exemplo das muitas açōes realizadas por Matta-Clark que requisitavam a participação direta do público e da comunidade local, que pressupunham um ato corporal e socialmente engajado, em toda a sua carga política ativista. 


\section{POÉTICAS EMERGENTES}

No Brasil dos anos 1960, as motivações para o alargamento do objeto artístico e para a conquista de outros lugares da arte se somaram muitas vezes ao enfrentamento das contingências políticas produzidas pela drástica ruptura do golpe militar que cindiu um processo de modernização e o otimismo em relação a um projeto de futuro para o país. Em meio à restrição das liberdades individuais e ao endurecimento programático do plano nacional desenvolvimentista, uma profusão de iniciativas experimentais renovou os lugares da arte até então conhecidos e transformaram as práticas para além de sua condição objetual, utilizando novos meios, fundando novas linguagens ou embaçando seus limites.

Em 1967, Oiticica chegou a usar o termo antiarte, em texto escrito por ocasião da célebre mostra Nova objetividade brasileira, realizada no Museu de Arte Moderna do Rio de Janeiro, para expressar o movimento de ruptura do objeto de arte que as novas manifestações artísticas incutiam:

Devemos abordar e delinear a razão do ressurgimento do problema da antiarte que a nosso ver assume hoje papel mais importante e sobretudo novo. [...] Sente esse artista [brasileiro] uma necessidade maior, não só de criar simplesmente, mas de comunicar algo que para ele é fundamental, mas essa comunicação teria que se dar em grande escala, não numa elite reduzida a experts, mas até contra essa elite, com a proposição de obras não acabadas, "abertas". É essa a tecla fundamental do novo conceito de antiarte: não apenas martelar contra a arte do passado ou contra os conceitos antigos, mas criar novas condições experimentais, em que o artista assume papel de "proposicionista", ou "empresário", ou mesmo "educador”. ${ }^{66}$

66 Oiticica, Hélio. Esquema geral da nova objetividade brasileira [1967]. Aspiro ao grande labirinto. Rio de Janeiro: Rocco, 1986, p. 97
Essas manifestaç̃es, identificadas no guarda-chuva da "nova objetividade", foram interpretadas por Otília Arantes como neovanguarda, uma postura que rompia com o passado, e que "opunha a toda forma de esteticismo uma arte-vida-ação". ${ }^{67}$ Segundo a filósofa, à renovação dos ideais das vanguardas históricas se somava a algo próprio da arte brasileira; em outras palavras, à arte destrutiva do dada, principalmente na figura de Marcel Duchamp, somava-se o élan construtivo nacional. ${ }^{68}$

Boa parte dessas novas manifestações convocava a uma imersão do sujeito na obra, no seu envolvimento "plurissensorial" e na sua existência política. Um dos marcos dessa implosão é o programa ambiental de Oiticica, que incluía os parangolés, os quais instauraram um novo modo de se relacionar com a obra, incorporando o observador-participante no seu acontecimento espaco-temporal. Também fazia parte dessa imersão poética na vida real uma série de manifestações ensejadas no espaço público por meio do caminhar, a que o artista deu o nome de Delirium ambulatório, já comentada anteriormente.

Para o historiador da arte Walter Zanini, os novos desígnios da sociedade de massa e da cultura urbana apontaram para uma reordenação realista do mundo, pela qual a arte absorvia seus conteúdos simbólicos, no sentido de uma aproximação entre o mundo da arte e a vida cotidiana. "Houve efetivamente uma ruptura com as atitudes exclusivamente formalistas, na busca de vínculos imediatos com a existência ao redor". ${ }^{69}$ A nova "intencionalidade moderna", reformulada pelos artistas quanto ao desejo de reconectar as esferas da arte e da vida, também pode ser identificada na reivindicação da participação do observador como coautor da obra - tal como em algumas das proposições neoconcretas dos anos 1960.

67 Arantes, Otília B. F. Depois das vanguardas, Arte em revista (Pós-moderno), ano 5, n. 7, ago. 1983, p. 5. 68 Ibidem.

69 Zanini, Walter (org.). História geral da arte no Brasil. Vol. 2. São Paulo: Instituto Walther Moreira Salles/Fundação Djalma Guimarães, 1983, p. 738. 
Happenings, performances, ações e intervenções transformavam o caráter permanente da obra de arte num acontecimento, como obra-processo, fluxo de informações ou ainda como deslocamento de objetos. Além das experiências de Hélio, outras iniciativas emergiam desse cenário: em 1967, Exposição não exposição, de Nelson Leirner, parodiava a condição de "loja" do formato galeria, e de mercadoria, da obra de arte; em 1970, Inserções em circuitosideológicos de Cildo Meireles, atingia os circuitos das trocas mercantis e informacionais; em 1973, De o a 24 horas, de Antonio Manuel, formalizava-se como uma exposição-protesto na mídia impressa; para citar alguns exemplos.

\section{O AMBIENTE PAULISTANO}

Do ponto de vista das transformações da vida urbana do período, São Paulo sobressaia-se como a meca do desenvolvimentismo do país, baseada no seu parque industrial (especialmente o automobilístico). ${ }^{70} \mathrm{E}$, como tal, afirmava-se como paradigma urbano nacional - não do ponto de vista político, como Brasília, nem em termos culturais, como o Rio de Janeiro, mas como centralidade econômica, do produtivismo industrial, da ideologia do trabalho e da eficiente circulação de serviços e bens de consumo. Por trás de tudo isso, estava o "milagre econômico brasileiro".

Segundo Cândido Malta Campos, ao longo da década de 1970, na capital paulista

70 Entre 1961 e 1964, a capital tinha sido administrada pelo engenheiro Francisco Prestes Maia, cuja gestão foi marcada por grandes obras viárias, a exemplo da avenida 23 de Maio. O período iniciado com o golpe militar de 1964, na gestão Faria Lima, ficou igualmente identificado por grandes obras viárias que consagrariam o império do automóvel na cidade tais como o Elevado Costa e Silva (mais conhecido como Minhocão), as vias expressas das marginais dos rios pinheiros e Tietê, as ava (mais Bandeirantes Brás Leme e Radia Leste, o alargamento da avenida Paulista e da rua lgua avenidas

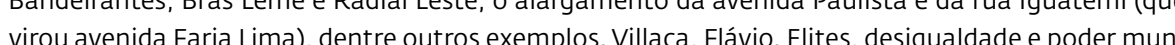
cipal Campos, Candido Malta: em trânsito: percursos urbanos e culturais. São Paulo: SENAC, 2014, p. 150. acentua-se o crescimento extensivo e desordenado, a verticalização, a expansão da periferia e os déficits urbanos; esboça-se uma estrutura de planejamento tecnocrático. Tensões políticas culminam em movimentos sociais urbanos e uma cultura de resistência. A Grande São Paulo assume perfil decididamente moderno, passando de metrópole industrial a megalópole terciária, e tornando-se, não apenas em tamanho, a primeira cidade do país ${ }^{71}$

Nesse cenário, a emergência de uma produção artística de viés crítico em relação ao circuito institucional vigente e atenta direta ou indiretamente às transformações da vida urbana em São Paulo esteve de algum modo relacionada ao ambiente universitário, protagonizado pelos cursos pioneiros da FAAP, da FAU-USP e, logo em seguida, da ECA-USP. Neste ambiente paulistano aflorava boa parte da produção experimental local do período, cujos vínculos se dariam na e para além das salas de aulas, a exemplo da criação laboratorial do espaço B do Museu de Arte Contemporânea da USP.

Enquanto o contexto experimental carioca foi estimulado pela figura crítico-criadora de Frederico Morais - que vislumbrou em certos artistas (entre eles Cildo Meireles, Antonio Manuel, Artur Barrio, Thereza Simões, Luiz Alphonsus e Guilherme Magalhães Vaz) a possibilidade de trabalhar conjuntamente na direção de uma nova arte de vanguarda, que deveria se dar nas bordas das instituições e endereçada às contingências da vida pública -, o ambiente paulistano se mostrou mais introvertido. As iniciativas experimentais eram ora fomentadas no meio universitário (a exemplo das atuações de Walter Zanini, no MAC-USP, e Flávio Motta, na FAU-USP), ora protagonizadas por artistas e grupos independentes. Cabe citar aqui alguns exemplos que se destacaram na construção de uma certa narrativa local: o Crupo Rex e seus membros (Wesley Duke Lee, Geraldo de Barros, Nelson Leirner, José Resende, Carlos Fajardo e Frederico Nasser); alguns artistas oriundos 
do Curso de Formação de Professores de Desenho da Escola de Arte da FAAP, criado por Flávio Motta, como Marcello Nitsche e Carmela Cross; artistas que circulavam nos espaços laboratoriais do MAC-USP, como Julio Plaza, Regina Silveira, Gabriel Borba e Sônia Andrade; e, mais para o final da década, os grupos independentes "marginais", tais como o 3Nós3 e o Viajou sem Passaporte (formados por estudantes da ECA-USP e da FAU-USP, respectivamente)

Nesse caldeirão de experimentações, ao menos três tendências emergiram no horizonte das práticas impregnadas pelas contingências da vida urbana paulistana: uma de vocabulário pop, produzida como ironia ou paródia; outra, de raiz conceitual, que explorava a linguagem como meio; e a última, "marginal", que procurou criar as brechas necessárias para se respirar na cidade sob controle militar do estado. Por diversas vezes essas tendências se entrecruzaram e produziram uma instigante cena experimental.

Da primeira vertente, Marcello Nitsche desponta como um artista tipicamente paulistano, ao se apropriar da materialidade industrial da cidade para ironizá-la em formalizações pop bem-humoradas. Já em meados de 1960, o artista parodiava os ícones da sociedade paulistana (da industrialização, da ideologia do trabalho, do automóvel, dos eletrodomésticos...). Em 1967, a passagem de Nitsche pela exposição Nova Objetividade Brasileira marcara sua obra pictórica pela valorização objetual, do objeto como novo estatuto da cultura urbana. A partir de 1968, seus trabalhos ganharam uma aparência maquínica, decorrente da impregnação da vida urbana industrial, e que lembra a ironia duchampiana. Como ressalta a historiadora da arte Ana Maria Belluzzo,

a nova visão da natureza moderna impõe-se pela paisagem urbana aos jovens artistas brasileiros atuantes em meados dos anos 1960. Fábrica e cidade constituem a moderna paisagem e marcam, de modo peculiar, a experiência artística de Nitsche entrelaçada à vida de São Paulo.72

72 Belluzzo, Ana Maria M. Lig des: Marcello Nitsche. (Catálogo de exposição). São Paulo: Sesc Pompeia, 2015, p. 5.
Belluzzo pontua que, nos anos 1960, "jovens artistas atraídos pelas falas que se cruzavam pela cidade afastaram-se estrategicamente de cânones visuais de tradição culta e se acercaram da linguagem da vida cotidiana". ${ }^{73}$ Marcello acompanhara o crescimento vertiginoso de São Paulo com uma câmera fotográfica na mão; no sightseeing da cidade, admirava a beleza industrial de tubos conectores, turbinas e chaminés fumegantes, bem como os expressivos códigos de comunicação urbana. Dentre os registros feitos no período, Nitsche realizou um filme com o artista e professor Flávio Motta sobre o Elevado Costa e Silva, que representava a supremacia do automóvel na cidade à época. Motta elegeu o espaço residual sob o Minhocão para colorir a cidade. Na intervenção sobre os pilares do elevado, executou composições geométricas, pensadas para serem vistas sequencialmente, sob o olhar em trânsito, como num cinema ao ar livre. O conjunto Caminhos do Jaraguá foi inaugurado em 1974, e todo o processo foi documentado por Nitsche no filme. Motta dizia que "o fundamental é tornar a cidade um campo de relacionamento humano mais amplo, inteligível, observável, correspondendo às aspirações do desenvolvimento social". 74

Na perspectiva de se lidar com as transformações da vida urbana no despontar da década de 1970, enquanto certos artistas operavam em vocabulário pop, outros se dedicavam a estratégias mais discursivas ligadas a vertentes conceituais, como era o caso de Regina Silveira. No início da década, Silveira experimentava a imagem nos laboratórios promovidos por Zanini no MAC-USP, adentrando uma fase de exploração dos novos meios visuais. Esse movimento se alimentava da crescente circulação da fotografia nos veículos de comunicação de massa e sua impregnação na vida cotidiana dos grandes centros urbanos.

A obra da artista produzida no período estava incutida pela problemática da representação, tanto no que diz respeito aos códigos tradicionais do

73 lbidem, p. 10

74 Motta, Flávio. Textos informes. São Paulo: FAU-USP, 1973, p. 5. 
desenho quanto aos novos usos da fotografia que questionavam sua verossimilhança com o real. Em depoimento, Regina declara que "o elemento transformador maior para o salto multimídia dos anos 70 foi a fotografia, o meio mais pervasivo para registrar conceitos, ações e eventos, por ope rações de registro e montagem". ${ }^{75}$ Sua fala corresponde ao que a historiadora da arte Annateresa Fabris apontara sobre o significado da opção pela fotografia, perseguida mais como signo e estrutura cultural, do que como organização formal. ${ }^{76}$

As primeiras apropriações de imagem de Silveira datam de 1971. No álbum Middle Class Co., a artista faz uso de fotografias de multidão extraídas da mídia impressa, compostas por indivíduos "genéricos", sobre as quais aplica um grafismo geometrizado. O amálgama corpóreo resulta do meio serigráfico, que induz a uma simplificação do desenho transferido para a matriz; o emprego de uma única cor ajuda a produzir a homogeneização espacial. 0 conflito entre forma e conteúdo, ressaltado pelo viés irônico, incute a dimensão crítica de Silveira, ao questionar o valor dos atributos de uma espacialidade estruturante, própria do urbanismo moderno, bem como a padronização do grupo social representado.

A partir de 1973, as serigrafias apontam uma justaposição de questões gráficas e representacionais a questões relativas à cidade. É no limiar dessa década que a pauliceia passa a viver sob o ritmo desenfreado do automóvel, das grandes avenidas e da multidão. Em Brasil Turístico/SP/Viaduto do Chá, Regina se apropria de cartões-postais com imagens do centro da cidade e as remonta como cenário de uma pilha de carros sucateados. A fotomontagem é impressa em offset e faz parte da série Publicações On/Off, uma parceria com Julio Plaza. Em Proposta para Monudentro, outra montagem da série, a imagem do Monumento às Bandeiras, de Victor Brecheret, marco do orgulho paulista prefigurado

75 Silveira, Regina. Regina Silveira: compêndio (RS). (Catálogo de exposição). Belo Horizonte: Museu de Arte da Pampulha, 2007, p. 2

76 Fabris, Annateresa. Sombras simuladoras. Moraes, Angélica de (org.). Regina Silveira: cartografias da sombra. São Paulo: Edusp, 1995, p. 190 no herói bandeirante, habita um cemitério de automóveis. A recorrência de montanhas de sucata automobilística ironiza o progresso trazido pelo maior parque industrial do país. E lembra ainda o imaginário das cenas imortalizadas por Andy Warhol na série Car Crash (1963-1965) e das compressões de automóveis (1962) de César.

No conjunto de serigrafias Desestruturas urbanas (série Interferências), de 1976, as malhas ortogonais pousam sobra a cidade, em diferentes contextos urbanos: sobre grandes avenidas, em skylines de áreas verticalizadas, ou ainda separando carros e pedestres ao rés do chão. Novos símbolos da vida moderna passam a figurar como cenário: a verticalização; a mobilidade e o tráfego; as superestruturas da engenharia; a centralidade dos negócios na avenida Paulista; os primeiros símbolos nacionais da indústria local, como a Kombi; o mundo peatonal em conflito com a circulação privilegiada de veículos. Nas fotomontagens de Silveira, a São Paulo moderna é problematizada pela justaposição de situações díspares que constroem um cenário surrealista, entre uma ordem abstrato-geométrica que controla a urbe de cima e uma ordem concreta, caótica, da vida cotidiana.

Uma terceira via da produção de arte que emergiu das novas dinâmicas da vida urbana na capital paulista diz respeito a artistas que se aventuravam a desbravar os vínculos imediatos com a dimensão prático-sensível do cotidiano metropolitano. Para estes, a rua ganhou centralidade em suas práticas - ora como lócus alternativo para a realização de trabalhos, ora como matéria propulsora na orientação de suas intenções poético-espaciais. Exemplo disso são as experiências performáticas realizadas por Ivald Granato, Gabriel Borba e Fred Foster. Em 1973, a convite de Vilém Flusser para participar da 12a Bienal de São Paulo, Foster realiza seu Passeio Sociológico ao Brooklin, uma manifestação de rua pelo bairro, registrada em fotografia. Os projetos de Foster eram um misto de criação estética e experimentação sociológica, por meio dos quais travou um embate com a rua e o espaço urbano, então dominados pelas forças ditatoriais e pelos meios de comunicação de massa. 
Mais adiante, diversos grupos independentes despontaram em São Paulo, a exemplo do Arte/Ação, ${ }^{77}$ Manga Rosa, ${ }^{78}$ Viajou sem passaporte79 e 3Nós3. Boa parte deles trabalhava a partir da materialidade urbana, frequentemente em ações furtivas extramuros. Partindo de uma atuação "marginal", utilizavam espaços inusitados como base de suas intervenções: outdoors, ônibus, viadutos, ruas, monumentos públicos, além dos espaços já estabelecidos no circuito, como galerias, teatros e jornais. ${ }^{80}$

Dentre as manifestações artísticas realizadas no meio urbano propostas pelo grupo 3Nós3, destaca-se a estratégia inaugural criada por seus três integrantes - Hudinilson Jr., Mario Ramiro e Rafael França - para encapuzar cerca de 80 monumentos públicos de São Paulo na madrugada do 27 de abril de 1979. Não à toa, através de um mapeamento da cidade, o trio elege um conjunto de esculturas públicas, símbolos da história oficial da cidade e do gosto do poder, para negá-las no que representam como ideologia, cultural e política. Concretizada como uma espécie de guerrilha urbana, a ação furtiva de cobrir com sacos de lixo as cabeças das figuras monumentalizadas se dá de madrugada, a despeito da possível abordagem pela ronda policial. A ação não se efetivaria sem o alarde que o grupo faz à imprensa na manhã seguinte, convocando-a a conferir o que se passava na cidade.

De certa fora, tinha um pouco a ver com uma ideia de urbanismo, porque todas as cidades têm espaços reservados para a construção de monumentos. A intenção era espacialmente cobrir uma certa arte acadêmica visível na cidade; a nossa ideia estava muito mais

77 A formação original do grupo contou com Genilson Soares, Francisco Iñarra e Lydia Okumura, tendo atuado coletivamente até 1979 .

78 O grupo reunia estudantes do curso de Arquitetura e Urbanismo da USP, dentre eles Carlos Dias, Francisco Zorzete e Joca.

79 O grupo era formado por alunos da ECA-USP: Beatriz Caldano, Celso Santiago, Carlos Alberto Gordon, Luiz Sergio Ragnole Silva, Marli de Souza, Márcia Meirelles, Marilda Carvalho e Roberto Mello. 80 Palhares, Taisa. Anarquismo construtivo [?!], número, n. 1. Disponivel em: <http://www.forumpermanente.org/rede/numero/rev-numero//taisaznosz>. Acesso em 3 dez. 2016. ligada a um ataque a esse academicismo que, por sua vez, é representante da história oficial do Brasil, que é a história do governo, a história do Estado. ${ }^{81}$

Segundo depoimento de Ramiro, a profusão de iniciativas marginais do período buscava restaurar uma tomada cívica da cidade. A atuação direta do grupo no território da cidade representava ao mesmo tempo uma alternativa à falta de espaços expositivos para esses jovens artistas e uma conquista "cívica" do espaço público, via negação das representações oficiais reverenciadas na cidade em espaços públicos exclusivos.

\section{HIBRIDISMO DOS MEIOS}

Nos últimos trinta anos, as pesquisas plásticas, avançando além da arte moderna, nada mais fizeram que radicalizar e aprofundar diversas questões, entra as quais romper com a ideia da especialização do artista em um meio específico - busca da essência -, combater a discriminação entre materiais e meios artísticos e não artísticos e ampliar o campo de atuação da arte para além de um espaço próprio, fechado, que não se relacionasse com outros campos do conhecimento. ${ }^{82}$

Das características que se percebem evidentes na arte contemporânea, a transdisciplinaridade e o hibridismo parecem despontar como as mais expressivas nas últimas décadas, e de certa forma perpassam toda a obra de Rubens Mano, a ser analisada adiante. A transdisciplinaridade diz respeito

81 Depoimento de Mario Ramiro para a exposição Obra e documento - Arte/Ação e 3Nós3, realizada no Centro Cultural São Paulo em 2012. Disponível em: <https//vimeo.com/61711050>. Acesso em 5 dez. 2015

82 Basbaum e Coimbra, op. cit., p. 346 
ao cruzamento e superposição de diferentes campos do conhecimento e como tal põe em evidência um interesse cada vez maior do artista pelo diálogo fora do meio especializado da arte. Por sua vez, a hibridização dos meios (ou o que Basbaum e Coimbra chamaram de intermídia) implica o livre trânsito entre diferentes meios de expressão, tradicionais ou não, e a utilização de diversos materiais, artísticos e extra-artísticos.

Na década de 1990, na qual Mano inscreve as primeiras formulações de sua obra madura, essas estratégias miscigenadas eram recorrentes - a exemplo da exposição Fotografia contaminada, em que o artista toma parte - e por vezes serviram como dispositivos para operar um enfrentamento do mundo, diante da geografia desenhada pela globalização e pela financeirização das trocas culturais. Diferentemente dos anos 1990, o hibridismo tinha sido uma das marcas impressas pela produção da década anterior como subterfúgio para se "escapar" da temática "homem e meio", própria das práticas contextuais dos anos 1960 e 1970; em lugar disso, a geração de artistas dos anos 1980 mergulhou em um debate formal da arte, interessada em experimentar o livre trânsito entre meios e estilos.

Como marca registrada dos anos 1980, o hibridismo de meios se colocou como uma bandeira de libertação a ser perseguida ao longo da década. Conforme apontou a crítica de arte Ligia Canongia, o ano de 1983 marcou o lançamento das bases dessa libertação: a mostra Aperto 80, organizada pelos curadores Harald Szeemann e Achille Bonito Oliva dentro da programação da Bienal de Veneza, reuniu a nova geração da transvanguarda; de modo geral, essa geração misturava a história da arte e seus estilos de forma transversal e eclética e as juntava à baixa cultura dos ícones de massa.

A partir dessa mostra coletiva, percebia-se que a obra de arte se instaurava como lugar de transição, local de passagem ou convergência entre vários estilos, forma de esquemas plásticos ou teóricos fixos, fazendo um apanhado indiscriminado de diversas vertentes do passado histórico e da herança moderna, tal hibridização participava do esforço pós-moderno de substituir hierarquia por multiplicidade, evolução por contaminação, tentando desbloquear os ciclos autônomos do modernismo. ${ }^{83}$

A partir de uma abordagem simultânea e multifacetada de vários estilos, épocas, referências e culturas, era possível reconciliar linguagens contraditórias e diferentes, fragmentos descontínuos numa verdadeira "colisão de linguagens", nos termos postos por Canongia.

De acordo com o crítico de arte Mário Pedrosa, a produção da década foi marcada pelo valor na diferença, ressaltada por três motivações: "o questionamento da estética modernista e suas aspirações em definir modelos autônomos e conclusivos; as ressonâncias de um novo capitalismo, atrelado à publicidade, ao consumo de massa e à tecnologia eletrônica; e, por fim, a dissolução do estilo". ${ }^{84}$

Além do hibridismo, os anos 1980 trouxeram de volta a questão da subjetividade, do gesto e da emoção, revigorando ao mesmo tempo o drama e a teatralidade de verve romântica, cuja expressão mais evidente foi explorada pela geração de pintores, tanto nacional como internacionalmente. A natureza artesanal da pintura significava além de tudo uma alternativa ao avanço tecnológico desenfreado do período e sua parafernália eletrônica, bem como o reencontro corporal dos artistas com seus meios.

No meio da crítica especializada, a geração 80, como ficou conhecida, acabou instaurando uma nova polêmica em torno do "retorno à pintura": trazia ela uma qualidade libertária, uma via crítica à razão iluminista que permeou a modernidade? Ou revela-se como mera "renúncia moral" aos problemas da contemporaneidade e da história? Ou, mais ainda, como uma alienação estética, definida pelos imperativos do mercado? Independentemente de juízos de valor endurecidos, o fato é que a crítica ao sistema mercadológico (cujas trocas cresceram significativamente no período, a ponto

83 Canongia, Ligia. Os anos 80 e o retorno à pintura. Canongia, Ligia (org.). Anos 80: embate de uma geração. Rio de Janeiro: Barleu/Francisco Alves, 2010, p. 7.

84 Mário Pedrosa apud Canongia, op. cit., p. 20 
de colaborarem para a profissionalização do meio) chegou a se imiscuir com a crítica às próprias obras, tomando a nova produção como conivente com o jogo capitalista do mercado e com a emergente indústria cultural. Pela primeira vez, artistas recém-formados eram rapidamente apropriados pelo circuito e transformados em ícones, a exemplo dos jovens pintores paulistanos da Casa 7.

Tal como no meio internacional, os artistas que por aqui produziram ao longo dos anos 1980 se mostravam mais interessados no embate pessoal com a história da arte do que com a história do homem e das sociedades. O ícone dessa nova produção "energética” foi a exposição Como vai você, geração 80?, realizada no ambiente laboratorial da Escola do Parque Lage, em 1984, um ano após a mostra de Bonito Oliva.

A mostra do Parque Laje, que se configurou como um gigantesco caleidoscópio das práticas emergentes no eixo Rio-São Paulo, confirmou a retomada da pintura no Brasil, com a constatação da vertente neoexpressionista [...], mas também deixou transparecer nitidamente o interesse dos jovens pela pop, com preocupações ligadas à urbanidade e aos meios de massa..$^{85}$

A historiadora da arte Aracy Amaral reuniu as características dessa geracão no texto "Uma nova geração", publicado em 1991: "a pintura sem chassis, a lona substituindo o linho, os suportes mais livres possíveis, autonomia para a seleção de formatos, dimensões inusuais em seu gigantismo para jovens que apenas se iniciavam". ${ }^{86}$

Em São Paulo, Tadeu Chiarelli organizou a exposição Pintura como meio, em 1983, no Museu de Arte Contemporânea da USP, com a participação de Ana Maria Tavares, Ciro Cozzolino, Leda Catunda, Sérgio Romagnolo e Sérgio

85 Canongia, Ligia. O Brasil nos anos 80. Canongia (org.), op. cit., p. 35.

86 Amal, Aracy A U Una nova geraça [1901] Textos do trópico de capricórnio: artigos e ensaios (19802005), op. cit., p. 206.
Niculitcheff. Ainda que sob o guarda-chuva da pintura, a mostra renovara o ponto de vista sobre o meio tradicional ao reunir um grupo de artistas que buscava desmistificar a pintura modernista, ao explorar a técnica sob novas formalizações, atravessadas por outras linguagens, com suportes inusitados, e impregnadas de imagens do mass media. Dois anos depois, a Bienal Internacional de São Paulo selava a geração da transvanguarda na "grande tela" de Sheila Leirner.

De modo geral, a abertura a uma total hibridização dos meios e à transdisciplinaridade com outros campos do conhecimento cimentou um terreno livre para a década seguinte. Diante do crescente acirramento do mercado de arte (e sua especulação) e da internacionalização da arte brasileira na economia global, a experiência da transvanguarda propiciou o surgimento de práticas artísticas elaboradas como um acontecimento-obra, no limite entre a arte e a "não-arte", conquistando um espaço de atravessamento entre mundos. Essa disposição para uma atitude híbrida e transversal, como ver-se-á adiante, marcará a obra de Rubens Mano como um dos aspectos mais expressivos de sua trajetória. 
capítulo 2

Imagens

performáticas 
O SER URBANO NÔMADE

"Desligar-se para saborear melhor a proximidade das coisas". ${ }^{86} \mathrm{~A}$ frase é do sociólogo francês Michel Maffesoli, autor que aparece como uma das referências teóricas importantes eleitas por Rubens Mano em sua dissertação de mestrado para pensar suas ações na cidade ao longo dos anos 1990. No livro Sobre nomadismo, publicado em 1997, o autor tratou de investigar a sociedade urbana, partindo do pressuposto de que o ser urbano é por natureza nômade. Para ele, o caráter dialético da estrutura social (entre indivíduo e comunidade) se expressaria no seu modo de vida urbana como enraizamento e errâncias. "Numerosas são as ocasiões de todo tipo em que se 'soltam as amarras', em que a pessoa se exila ou foge a fim de restituir o sabor àquilo que, sob pesados golpes da rotina, perdeu-o quase que totalmente". ${ }^{87}$ É como se o cotidiano metropolitano intenso anestesiasse qualquer tipo de relevo perceptivo por parte de quem o vivencia.

A partir dos anos 1990, a arte contemporânea parece ter resgatado tal essência errática num ato de resiliência diante das aceleraçooes da vida urbana promovidas em boa parte pelas contradições advindas da inviabilidade em se urbanizar pari passo com o crescimento das cidades, de um lado; e pela intensificação das trocas virtualizadas decorrentes dos avanços da tecnologia informacional, de outro. Este parece ser o caso de Rubens Mano. Ao longo da década, o artista realizou uma série de intervenções na cidade de São Paulo desencadeadas pela sua experiência de deslocamento no território paulistano.

Neste primeiro capítulo dedicado ao estudo das obras de Mano (Capítulo 2), o conjunto de trabalhos que se apresenta reúne uma série de exemplares em fotografia produzidos entre meados dos anos 1990 e meados dos anos 2000 , mobilizados pela experiência de deslocamento no território, a saber: bueiro, disponha, casa verde, entre e a série súbitas paisagens. Eles implicam ações realizadas

86 Maffesoli, Michel. Sobre o nomadismo: vagabundagens pós-modernas [1ª edição 1997]. Rio de Janeiro: Record, 2001, p. 77 .

87 Ibidem. 
majoritariamente no espaço urbano, que problematizam os códigos e estruturas fundados em certos lugares, e que foram em seguida transpostas para a fotografia. A esse conjunto deu-se o nome de "imagens performáticas", as quais carregam indícios das ações do artista realizadas no tempo-espaço da cidade.

A fim de desvendar a relação intrínseca entre os percursos realizados na cidade e a construção de lugares promovidos pelo artista, a pesquisa buscou recuperar os significados do caminhar e sua essência urbana nômade em práticas artísticas anteriores, que deixaram contribuições para a história da arte contemporânea.

Sabe-se que a invenção do caminhar pela cidade como experiência estética aparece desde os tempos baudelairianos, na Paris do século XIX, tendo na figura do flâneur sua maior expressão. No início do século XX, ela é explorada pelas vanguardas históricas, notadamente via dadaísmo e surrealismo. Porém, é na década de 1960 que a prática se intensifica e ganha estatuto de obra de arte. Algumas de suas abordagens destacam-se no período, a saber: para reestabelecer o sentido de pertencimento a certos lugares em busca de uma nova identidade do sujeito e do lugar, tal como na prática de deriva proposta pelos situacionistas; para afirmar a natureza tautológica do ato de andar, presente nos registros fotográficos de Richard Long (1945); para deflagrar a experiência do território urbano numa perspectiva discursiva, a exemplo dos passeios de Smithson; como fenomenologia do sujeito social, no caso do programa ambiental de Oiticica; ou ainda como desencadeadora de ações que flertam com o ativismo político, em certos trabalhos de Matta-Clark.

No livro Elogio aos errantes, a arquiteta Paola Berenstein Jacques define essas experiências pelo território como errâncias urbanas. A especificidade da experiência errática das cidades é apresentada pela autora na seguinte passagem:

A experiência errática afirma-se como possibilidade de experiência urbana, uma possibilidade de crítica, resistência ou insurgência contra a ideia do empobrecimento, perda ou destruição da experiência a partir da modernidade, levantada por Walter Benjamin e retomada por Ciorgio Agamben, que radicaliza a questão ao sugerir o que seria uma expropriação da experiência. Mesmo vivendo um processo de esterilização da experiência hoje, esse processo, que, no caso das cidades contemporâneas, seria o processo de espetacularização urbana, não consegue destruir completamente a experiência - o que se aplica especialmente às cidades brasileiras -, embora busque cada vez mais sua captura, domesticação, anestesiamento. ${ }^{88}$

Tal como o faz Jacques, é importante qualificar e singularizar a experiência urbana do nomadismo (ou do caminhar, como preferem outros) no contexto das práticas artísticas. Sua genealogia implica uma recorrência quanto à tomada de posição crítica, muitas vezes de resistência mesmo, diante das transformações (segundo Jacques, "empobrecidas") da vida urbana. Algo que aparecerá com frequência na obra de Rubens Mano, a ser visto adiante.

Diferentemente das errâncias surrealistas ${ }^{89}$ e das derivas situacionistas exemplos igualmente citados no livro de Maffesoli como nomadismo urbano -, cujas práticas do caminhar constituem uma experiência urbana reveladora em si, os deslocamentos realizados por Mano na cidade são um meio pelo qual o artista vai aos poucos lendo o território e se apropriando dele. Como tais, eles precipitaram intervenções na cidade, nas quais o artista reconfigura certos lugares subvertendo seus usos e dinâmicas estabelecidos.

O conjunto de obras a ser investigado neste capítulo, portanto, diz respeito às andanças de Rubens pela cidade, seu olhar sobre a paisagem, suas inquietações acerca da natureza do lugar e suas descobertas nos meandros do espaço urbano. À formação do arquiteto, à fotografia como dispositivo de leitura do território e à prática de deslocamento no fotojornalismo, vivenciadas por ele na década de 1980, somou-se a natureza errante do ser urbano. Jun-

88 Jacques, Paola Berenstein. Elogio aos errantes. Salvador: UFBA, 2012, pp. 19-20.

89 No livro Novas derivas, o curador e crítico de arte Jacopo Crivelli Visconti cita como exemplo dessas errâncias "[...] a célebre ação de Andre Breton, Louis Aragon, Max Morise e Roger Vitrac, que em 1924 a mbularam vários dias sem rumo, a partir de uma cidade (Blois) escolhida ao acaso num mapa da França". Visconti, Jacopo Crivelli. Novas derivas. São Paulo: WMF Martins Fontes, 2014, p. 23. 
tas, elas conduziram o olhar do artista a experimentar a cidade de São Paulo com grande acuidade perceptiva, num processo investigativo desacelerado, a contrapelo da vida metropolitana, para descortinar a cidade em seus múltiplos extratos, construtivos, paisagísticos, históricos e culturais, nas marcas e usos impressos em cada lugar.

A percepção da natureza dos lugares escolhidos por Mano para suas ações e a transgressão de códigos desses lugares - cujo movimento afirma e nega ao mesmo tempo - corresponde ao que Maffesoli identificou como antagonismo paradoxal de toda existência social e nomeou como "enraizamento dinâmico". Se considerarmos a nova condição urbana das cidades pós-industriais, tal antagonismo poderia ser ilustrado nas figuras espaciais, cunhadas por Marc Augé, do lugar (lugar antropológico), que corresponde ao espaço praticado, e do não-lugar, este identificado numa existência desenraizada do sujei to própria do mundo globalizado, erigido na década de 1990. Esses lugares são exemplificados por Augé nos espaços "lisos" e genéricos ${ }^{90}$ dos aeroportos e shopping centers, mas também podem ser transpostos para situações de apagamento na cidade, onde bairros inteiros são demolidos, ou mesmo em situações de trânsito, como grandes avenidas expressas.

Porém, diferentemente de Augé, em Maffesoli elas são explicitadas como experiências dialéticas inevitáveis e, por isso mesmo, complementares. "Todo mundo é de algum lugar, e crê, a partir desse lugar, ter ligações, mas para que esse lugar e essas ligações assumam todo o seu significado, é preciso que sejam, realmente ou fantasiosamente, negados, superados, transgredidos", ${ }^{91}$ semelhantemente ao movimento realizado por Mano, sobre o qual serão tecidas as análises a seguir.

90 Em Rem Koolhaas, por exemplo, o autor as identifica na qualidade "genérica" da cidade, ou melhor, de partes dela, percebidas principalonte em suas "bolhas" empresariais, regiōes desconectadas do tecido urbano, caracterizadas porvolumetrias espelhadas que acondicionam um microclima artifica possibilitado pelo uso indiscriminado do ar-condicionado. Cf Koolhaas Rem. Grandeza ou o problema do grande [1994]. Três textos sobre a cidade. Barcelona: Gustavo Gili, 2010, pp. 13-27. 91 Maffesoli, op. cit., p. 79.

\section{A CONSTRUCC̃̃O ESPACIAL ATRAVÉS DA FOTOGRAFIA}

No início dos anos 1990, arquitetura, fotografia e a qualidade errática da experiência urbana da cidade se configuraram como elementos estruturantes nos modos de pensar e atuar de Mano, que, de certa maneira, continuam presentes até hoje. Boa parte das obras produzidas pelo artista ao longo da década se refere à construção de lugares, transpostos para a fotografia. $\mathrm{O}$ resultado imagético contém as evidências de uma experiência de deslocamento pela cidade, por meio do qual Rubens apreende o espaço, decodifica-o em suas normas e vocacões e reinventa estruturas perceptivas que transformam o lugar em um outro, ${ }^{92}$ fazendo com que o visível se transfigure em um sensível.

Essas fotografias se mostrarão parte da estratégia de Rubens para atuar na cidade, subverter certas estruturas de uso e poder tecidas no espaço urbano, e envolver seu observador na percepção do espaço ao reportá-lo ao acontecimento da ação/intervenção. Apesar de "congelarem" as ações no tempo, as imagens carregam indícios de uma duração da ação no tempo. No entanto, o autor da ação está sempre fora da cena. Tal opção tomada pelo artista deixa apenas rastros de suas intervenções na cidade, a fim de que as imagens contenham uma certa carga enigmática que incitaria o observador a desvendá-la, e no limite acionaria uma nova atitude perceptiva do sujeito diante da cidade.

Esses princípios da prática do artista foram fundamentados por ele ao longo de sua dissertação de mestrado. Rubens conceituou o conjunto de trabalhos realizados entre 1997 e 2002 a partir da noção de intervalo transitivo: "uma ação que se instala nas fissuras das estruturas responsáveis pela

92 Ou, como define o artista, "um lugar dentro do lugar". Cf. Mano, op. cit., 2006b. Cabe observar ainda que o termo lançado por Mano curiosamente alude à historicidade da poética do site specificity, sobre a qual a crítica de arte norte-americana Miwon Kwon cunhou a expressão "um lugar depois do outro". Cf. Kwon, op. cit. 
constituição dos espaços, e que, ao mesmo tempo, é capaz de suspender momentaneamente nossos códigos perceptivos já disciplinados". ${ }^{93}$ Tal definição implica dois aspectos estruturantes nos modos dele se aproximar da cidade e de fazer arte: a escolha por espaços não óbvios na paisagem urbana, que se expressará em espaços secundários, abandonados ou sublimados pela lógica operativa da cidade; e a formulação da experiência como obra, que envolverá a construção de novas estruturas perceptivas propostas pelo artista e um público fruidor que deverá acioná-las - ambos situados numa condição urbana nômade, em que deixam de ser simples usuários da cidade para serem sujeitos ativadores de experiências e transformadores do próprio espaço.

Em Mano, a cidade é o motor da obra. O artista atua em resposta à cultura da cidade, na qual vai tecendo uma experiência. Até mesmo os vários itinerários percorridos pela região metropolitana de São Paulo são determinantes para a escolha dos locais pensados para suas ações. Em suas reflexões posteriores, reunidas em 2003 na dissertação de mestrado, Rubens pondera que tais escolhas "não foram construídas a partir de um roteiro ou percurso pré-estabelecido, mas 'orientadas' por certos fenômenos sociais percebidos no interior do ambiente urbano". ${ }^{94} \mathrm{Na}$ construção teórica desenvolvida no trabalho acadêmico, pela qual o artista explica as motivações que o levaram a conceber um conjunto de obras produzidas entre 1994 2002, Mano aponta a ocorrência de três fenômenos percebidos por ele no interior do espaço da cidade:

as "acelerações" da metrópole (percebidas como "potencializadoras" do estado de "desrealização" ao qual somos submetidos); a crescente "deslocalização" (criando uma demanda pelo que poderíamos chamar de "outros planos da realidade”); e os possíveis "desenraizamentos"

93 Cf. Mano, Rubens. intervalo transitivo. Dissertação (Mestrado em Poéticas Visuais) - Departamento de Ares Plásticas da Escola de Comunicações e Artes - ECA-USP. São Paulo, 2003 94 Ibidem, p. 25 vividos nas grandes cidades (responsáveis por experiências irremediáveis na constituição do "ser urbano").95

Eles correspondem, grosso modo, ao tempo, ao lugar e ao corpo (em relação a ambos) na cidade, os quais se delinearam como aspectos centrais na obra do artista, diretamente associados à experiência contemporânea da cidade e à reflexão que Rubens tece sobre ela. E, como tais, auxiliaram nas leituras das obras deste capítulo, principalmente no que se refere ao que é próprio do contexto urbano da cidade de São Paulo, desde a sua metropolização.

Por fim, antes de adentrar na análise das obras, cabe reforçar que as impressões de Rubens sobre São Paulo, contexto a partir do qual o artista produz, localizam-se em plena década da globalização. A capital paulista vinha paulatinamente ocupando uma posição de destaque no jogo global das trocas econômicas, que transformou suas configurações territoriais e urbanas, levando-a à sua coexistência como cidade real e cidade virtual. Ouem explica de modo claro e preciso os processos de globalização verificados nas cidades contemporâneas é o arquiteto Zeuler Lima, na seguinte passagem:

A maneira mais simples de se definir a globalização talvez seja entendê-la como a transformação das relações entre as elites econômicas mundiais, com todos os desdobramentos culturais e sociais que dela resultam. A expansão das redes de informação e de comunicação possibilitou a aproximação entre os mercados nacionais, a intensificação do fluxo de pessoas e de valores financeiros e simbólicos, e a concentração de recursos e investimentos em áreas, até recentemente, secundárias, principalmente no hemisfério sul. Com isso, houve desde os anos 1980 - período de instalação mundial do neoliberalismo capitalista - um crescente esforço em desregulamentar mercados e desestabilizar as fronteiras protecionistas dos Estados Nacionais 
que haviam sido o mote da modernização do segundo pós-guerra. Com o enfraquecimento das fronteiras comerciais, a formação de grandes blocos econômicos, o crescimento de fluxos migratórios e a concentração de recursos de ordem local, nacional e global em grandes metrópoles ao redor do mundo, essas cidades passaram a exercer um novo papel. Elas ganharam maior independência dos seus Estados Nacionais para negociar relações de produção, circulação e consumo e, principalmente, passaram a competir pelas vias de conexão com o mercado mundial. Com isso, nas últimas duas décadas, criou-se uma rede global de megacidades hierarquicamente organizada controlada que funciona ao mesmo tempo no novo espaço virtual das finanças e da informação e no velho espaço territorial do quotidiano do espaço urbano. 96

É nos anos 1990 que a vida urbana sofre uma aceleração potencializada pela circulação virtual de mercadorias e de dados, promovida pela tecnologia. Os lugares são cada vez mais imprecisos e impermanentes, desde shopping centers e condomínios residenciais até helicópteros e redes wi-fi. De modo geral, o sujeito vai aos poucos deixando de "habitar" o espaço urbano, no sentido heideggeriano de pertencimento, ${ }^{97} \mathrm{e} o$ anonimato produzido pelas multidões na modernidade vai se misturando ao anonimato das redes.

A disseminação das novas tecnologias e novos modos de vida vieram a acentuar a desorganização e reorganização do território paulista, produzindo uma fragmentação na ocupação dos espaços e tornando a leitura sobre a cidade mais complexa. À sobreposição de temporalidades distintas na cidade contemporânea corresponde um duplo fenômeno de deslocalização-relo-

96 Lima, Zeuler. Enclaves globais em São Paulo: urbanização sem urbanismo?, Arquitextos, São Paulo arquitextos $/ 05.05947$ 97 Cf Heidegger, Martin. Construir, habitar, pen.

Ensaios e conferências. Petrópolis/pl: vozes, 2001, pp. 124-141. calização, ${ }^{98}$ que implica o abandono de regiões, a transformação e a reutilização de partes da cidade. Sobrepondo-se a essa lógica de transformação urbana acelerada, a cidade de São Paulo é marcada, desde sua origem, pelo binômio da demolição-construção, que a coloca abaixo e a reconstrói incessantemente, num ciclo sem fim.

98 De acordo com a urbanista Marta Lagreca de Sales, "Os processos de'deslocalização' implicam seu duplo ('relocalizacão'), ou seja, fábricas, áreas portuárias, estacōes e pátios ferroviários são esvaziados de suas funções originárias, a mesmo tempo que lojas viram teatros, cinemas viram templos, estacões viram salas de conlos, a mas trangulas virem eixos de tráfego intenso". Sales, Mamplos, Lagreca de. Territórios de intermediačo: uma hipótese para a análise e o projeto da cidade contemporânea Tese (Doutorado em História e Fundamentos da Arquitetsa do Ura ismo) - Faculemporanca. Tese (Doutorado en Histónia e Fun Arquitetura e Urbanismo - FAU-USP, São Paulo, 2008, p. 43. 
bueiro (1999)

disponha (2001) 
Os percursos de Rubens Mano empreendidos pela cidade de São Paulo e que desencadearam suas primeiras ações no espaço urbano tiveram início em meados da década de 1990, quando começa a iluminar o interior de alguns buracos encontrados pelas ruas. Os vazios urbanos encontrados em suas andancas eram buracos localizados em ruas e meios-fios, os quais foram sinalizados pelo artista com o preenchimento de luz. A iluminação artificial ali produzida variava entre um alaranjado ardente e um branco etéreo, em contraste com a coloração acinzentada do asfalto. Essas intervenções, realizadas entre 1997 e 1999, foram reunidas pelo artista na série intitulada huecos [ocos].

Desta série, faz parte bueiro (1999), uma intervenção urbana na região do Bom Retiro - transposta, mais tarde, para fotografia -, na qual o artista escolheu uma boca de lobo localizada numa das esquinas do bairro paulistano como lugar para sua ação. A primeira parte da obra (intervenção) foi realizada durante a exposição f:(lux)os, individual do artista concebida para a Oficina Cultural Oswald de Andrade, estabelecida no bairro. Inicialmente, o convite da instituição se restringia à realização de uma obra nas dependências do centro cultural; entretanto, no lugar disso, Mano propôs a execução de cinco diferentes intervenções, que receberam os nomes de seus sítios (calçada, porão, telhado, bueiro e parede). ${ }^{99}$

Em bueiro, os dois buracos da boca de lobo foram preenchidos com luz branca, emitida de seis lâmpadas fluorescentes de 6oW cada, instaladas no local, e assim permaneceram por três dias (fig. 5). A boca de lobo é um lugar oco por construção, cuja funcionalidade é ser vazio para dar vazão às águas pluviais em dias de chuva. Contudo, sua realidade esvaziada não é perceptível ao caminharmos pela calçada numa rua qualquer na cidade; esses locais estão quase sempre tampados para que nenhum transeunte se acidente. Ela só se revela ocasionalmente, pelo distanciamento que o corpo toma da cal-

99 A apreciação das demais obras da exposição será desenvolvida num segundo momento, no conjunto de trabalhos abordados no Capítulo 3 . O espaço em ato desta tese. 


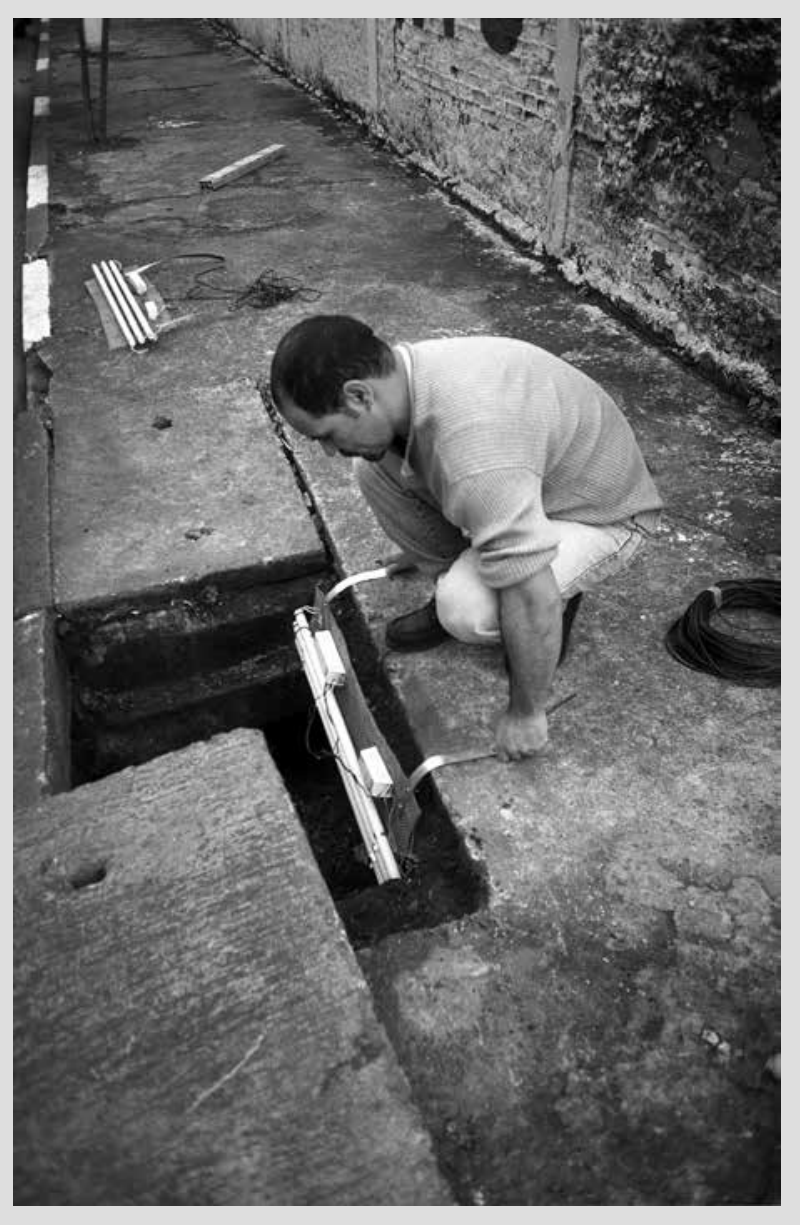

FIG. 5

Registro do processo de montagem

das lâmpadas nas bocas de lobo.

bairro do Bom Retiro, São Paulo.

Foto: Rubens Mano çada (ao cruzar a rua, por exemplo) ou pelo desvio do olhar para baixo (movimento não natural em nossas caminhadas pela cidade).

Ao iluminar esses pequenos e despercebidos vazios urbanos, o artista demarca a existência negativa desses espaços, preenchendo-os com o seu oposto, imaterial, uma estratégia para chamar a atenção para esses pequenos intervalos espaciais na cidade. De captadores passivos de água, os bueiros passam a emissores ativos de luz, invertendo-se o sentido do fluxo no seu interior.

A escolha de Rubens por lugares adjacentes, deslocados do olhar comumente direcionado de quem transita na cidade, para realizar suas intervenções vai ao encontro de uma das principais características de suas ações: a condição silenciosa destas, que geralmente se dão sem prévios alardes sobre sua ocorrência, nem tampouco são sinalizadas durante o seu acontecimento.

\section{A CONDIÇÃO SILENCIOSA}

O tipo de procedimento silencioso que Mano emprega na cidade remete às considerações tecidas por Lucy Lippard no ensaio Looking Around: Where We Are, Where We Could Be, publicado em 1995, no qual a crítica de arte norte-americana discorre sobre as novas formas de "arte pública" verificadas a partir dos anos 1990. Situando-as no campo das práticas contextuais, especialmente quanto ao contexto urbano das grandes cidades, a autora identifica que:

[...] os artistas que atuam na chave da "arte pública" podem criar espaços sociais e políticos em que as energias se reuniriam, dialogariam, e as alternativas ou oposições poderiam se concretizar. Estes podem ser vistos em relação à estratégia familiar de "enquadramento", na qual o que já existe é colocado em relevo pela adição de uma arte que chama a atenção. As formas de arte "parasitárias", como outdoors corrigidos, podem se apropriar da cultura dominante fisicamente, e ao mesmo tempo desafiá-la politicamente [...]. Outro conjunto de possibilidades é a arte que ativa a consciência de um lugar 
por marcas sutis sem perturbá-lo - um guia de folhetos, percursos de caminhada, ou sinais direcionais que sublinham a história de uma casa ou família, sugerindo as profundezas de uma paisagem e/ou o caráter de uma comunidade. ${ }^{100}$

Ao intervir sutilmente no espaço urbano, Mano busca acima de tudo demarcar seus códigos de uso e estruturas normativas, negando-os. A estratégia silenciosa e sutil de suas intervenções no espaço urbano coloca os trabalhos numa linha tênue entre o estar e o não estar na condição de arte. E isso se dá intencionalmente, mesmo sabendo do risco de elas passarem despercebidas. Em entrevista cedida à crítica de arte Thais Rivitti, em 2003, o artista expõe tal postura:

[elas] são realizadas sem que as pessoas saibam se tratar de um projeto ou serem informadas de que o que ali se apresenta deriva de uma prática artística. Como a participação não está pré-determinada, não há como prever a extensão ou a natureza dessas experiências. Elas podem inclusive não se dar ou acontecer algum tempo depois, como memória. ${ }^{101}$

De par com as considerações de Lippard, a estratégia de Mano para atuar na cidade é de certa forma uma resposta sintomática de sua geração diante da

100 "[...] public artists might set up social and political spaces in which energies could come together, dialogue and alternatives or opposition could be concretized. These might be seen in relation to the familiar 'framing' strategy, in which what is already there is put in sharp relief by the addition of an art of calling attention. 'Parasitic' art forms, like corrected billboards, can ride the dominant culture physically while challenging it pollitically [...]. Another set of possibilities is art that activates the consciousness of a place by subtle markings without disturbing it - a booklet guide, walking tours, or directional signs captioning the history of a house or a family, suggesting the depths of a tarr, or the character of a community" Lippard, Lucy. Looking Around: Where We Are, Where We Coup Lacy, Suzanne (org.). Mapping the Terrain: New Genre Public Art. Bay Press, 1995, p. 129.

The Insercões silenciosas [Entrevista com Rubens Mano], número. n. 1, São Paulo, maio/jun. 2003, p. 11 problemática do período: haveria espaco possível para os artistas atuarem incisivamente sobre a cidade a partir dos anos 1990? Que tipo de estratégias a arte interessada no lugar ("place-oriented") poderia operar a fim de abordá-lo numa perspectiva contextual renovada, que leve em conta os aspectos físico, social e político do lugar? Como reagir a essas tensões da vida urbana nas cidades a partir da década de 1990 ?

\section{A TRANSFIGURACCÃO DO OBSERVADOR EM PERCEPTOR}

Realizando-se sob uma condição silenciosa, as obras de Mano passam a requisitar o observador para ativá-las, lhe concebendo papel fundamental na sua completude. Tal como a disponibilidade do artista em experimentar os espaços da cidade, caracterizada por uma natureza urbana nômade, como posto por Maffesoli, o observador é convocado a ressignificar o espaço real (o que a priori seria uma simples reapresentação deste pela fotografia). A preocupação sobre as condições segundo as quais a experiência é acionada, ou percebida, faz parte da constituição dos trabalhos. Nas palavras de Mano, o usuário/observador é convidado a se converter em operador/perceptor. ${ }^{102}$

Em suas elaborações teóricas acerca das intervenções na cidade, Rubens chega a evocar a concepção do "ato criador" de Marcel Duchamp (1887-1968) para reafirmar o papel fundamental do observador na significação da obra. Para Duchamp, "O ato criador não é executado pelo artista sozinho; o público estabelece o contato entre a obra de arte e o mundo exterior, decifrando e interpretando suas qualidades intrínsecas e, desta forma, acrescenta sua contribuição ao ato criador". ${ }^{103}$

Tal como em Duchamp, no conjunto da obra de Mano tratado neste capítulo, a participação do sujeito-observador implica um ato perceptivo, mais

2 Mano, op. cit., 2003, p. 24

103 Duchamp, Marcel. O ato criador [1957]. Battcock, Gregori (org.). A nova arte. São Paulo: Perspectiva: 1975, p. 74. 
do que corporal e socialmente engajado - tal como proposto pelas manifestações ambientais de Oiticica nos idos de 1960 e tantas outras situações neoconcretas do período. Isso significa dizer que, de início, o sujeito precisaria estar disponível para perceber a intervenção no espaço como obra; e, no caso da transposição das ações em fotografia, o observador se defrontaria com a ambiguidade de uma imagem "construída", em que perceber a elaboração das ações ali registradas é parte da significação da obra.

\section{A FOTOGRAFIA COMO ÍNDICE}

A intervenção no bueiro ganhou uma versão fotográfica exposta um ano depois em báscula, ${ }^{104}$ mostra individual do artista realizada na Galeria Casa Triângulo em 2000. Na transposição fotográfica, o enquadramento da ação ocorrida no espaço real é dado pela centralização do assunto principal - os dois buracos iluminados, postos simetricamente lado a lado na imagem. $O$ ponto de vista frontal do registro da ação eleva esses pequenos vazios im perceptíveis como lugar de interesse. Além disso, os vazios luminosos são enquadrados na parte superior da imagem, subvertendo a sua condição horizontal da boca de lobo, muito abaixo do olhar do passante.

Aqui, a fotografia torna possível uma outra percepção sobre aquele lugar; ela apresenta uma ocorrência estranha e pouco evidente na cidade, conferindo novos significados a esse fenômeno luminoso, ou, ainda, produzindo um novo lugar, ressemantizado. Em bueiro, a atmosfera da imagem é carregada de certo mistério, que por sua vez incita o observador a reconstituir a ação inusitada naquele dado local.

A fotografia é o melhor meio para conhecer tal intervenção na cidade; o registro fotográfico é um dispositivo potente para a revisitação da experiên-

104 A partir daqui, todos os títulos de exposições concebidos por Rubens Mano serão grafados em caixa baixa, de acordo com designação do próprio artista. cia por parte do público. Ele permite acessar não apenas a ação espaço-temporal do artista, mas a própria memória e metamorfose da cidade. É preciso lembrar aqui que a natureza do meio fotográfico esteve em estreito diálogo com a vida urbana desde os primórdios das metrópoles modernas, a exemplo do estudo realizado pela crítica de arte Rosalind Krauss sobre as imagens surrealistas dos anos 1920. ${ }^{105}$

O artigo do historiador espanhol Ignasi Solà-Morales, "Terrain vague", retoma essa estreita relação entre fotografia e cidade e ajuda a elucidá-la.

Nascida praticamente no momento da expansão das grandes cidades, as imagens de Paris, Berlim, Nova York, Tóquio, ou as dos contínuos habitados no primeiro, segundo e terceiro mundo, entram em nossa memória e na nossa imaginação através da fotografia. ${ }^{106}$

Para Solà-Morales, a percepção que temos tanto da arquitetura quanto da cidade é uma percepção esteticamente reelaborada pelo olho e pela técnica fotográfica. O resultado é uma imagem mediatizada que, segundo os recursos da representação plana da fotografia, nos facilita a compreensão do objeto (no caso da arquitetura) e o acesso aos lugares e suas temporalidades (no caso da cidade). Segue o autor, "a possibilidade de acumular experiências pessoais diretas nos lugares nos quais não vivemos por um tempo é problemática. [...] A incidência do fotógrafo segue sendo primordial em nossa experiência da grande cidade". ${ }^{107}$

De acordo com Krauss, citada por Solà-Morales, "a fotografia não atua semiologicamente como um ícone, mas como um índice. Isso quer dizer que aquilo que constitui seu referente não está imediatamente relacionado, como

105 Cf. Krauss, Rosalind. Fotografia e surrealismo, op. cit., pp. 105-128.

106 Solà-Morales, Ignasi de. Terrain vague, ArchDaily Brasil, 10 mar. 2012. Disponivel em: <http://www. archdaily.com. br/br/o1-35567/terrain-vague-ignasi-de-sola-morales $>$. Acesso em 5 out. 2017. 107 Ibidem. 
figura, com as formas que a fotografia desenvolve". ${ }^{108}$ Portanto, conclui o historiador, "através da imagem fotográfica somos capazes de receber indícios impulsos físicos que dirigem numa determinada direção a construção de um imaginário que estabelecemos com um lugar ou uma cidade determinada". ${ }^{109}$

No caso de Mano, a imagem é um dispositivo duplo, de índice de sua intervenção em um dado lugar e de recodificação dessa reconstrução espacial imageticamente. Ao revisitar sua obra anos mais tarde, o artista relata que no projeto para os bueiros "intervenção e recepção foram considerados como um espaço contínuo, como campo da intertextualidade que articula duas realidades - a 'realidade material' do ambiente urbano e a 'realidade sensível' do espaço percebido ou transformado". ${ }^{110}$

A relação entre a ação e o registro da ação, ou ainda entre espaço e imagem de espaço, também está presente em disponha, um díptico em fotografia datado de 2001. Nele, Rubens coloca lado a lado o mesmo enquadramento de um trecho de uma rua aparentemente deserta com dois automóveis estacionados (possivelmente abandonados), em situações ligeiramente distintas. A diferença entre uma imagem e outra aparece na destruição parcial das carrocerias das kombis, porém não se sabe quem é o protagonista da ação que levou as partes sorrateiramente. Ao mesmo tempo, a alteração entre uma foto e outra, mesmo que efêmera ou paradoxal, perturba a "vocação" daquele lugar.

Em disponha, o anonimato da cena é parte da construção narrativa da obra, e expõe as contingências da vida urbana na capital paulista. $O$ artista se apropria de uma situação cotidiana recorrente no espaço da cidade, e faz dela sua "intervenção". Aos olhos dos curadores Lorenzo Mammì e Heloisa Espada, a obra é lida como uma "instalação ready-made". "11 No díptico, Rubens estabelece o "ato criador" como um processo anônimo, que é revelado na "coparticipa-

108 Rosalind Krauss apud ibidem.

109 Solà-Morales, op. cit.

110 Mano, op. cit., 2003, p. 27.

. São Paulo: IMS, 2013, p. 15 cão" entre artista e o sujeito-perceptor. O título ajuda a reforçar a ironia e o jogo duplo da imagem: num primeiro sentido, a cidade (e o que está no espaço público) se oferece a qualquer um de nós; num segundo, o dado autoral do trabalho de arte faz com que o artista responda "cordialmente" à ação transgressora, como se estivesse dialogando com o observador da obra, e, por extensão, com o sujeito na cidade.

Mesmo que a alteração dos carros (o corte na carroceria) tenha uma autoria dúbia, indefinida, o díptico de Mano articula uma "construção" por subtração, tal como em bueiros. Entretanto, a operação só é passível de ser compreendida pela fixação de um intervalo de tempo, ou seja, pela distância entre uma imagem e outra do par. A construção temporal na montagem fotográfica nos reporta novamente à fotografia surrealista, em especial às considerações de Krauss quanto à ideia de duplicação, proveniente daquela produção. Para a crítica de arte, a experimentação dessa vanguarda nos anos 1920 teria iniciado o alargamento das possibilidades do meio ao criar o duplo como recurso à dilatação temporal do real, projetando o original no campo da diferença. Diz ela: "é a duplicação que cria o ritmo formal do espaçamento, o pas-de-deux que proscreve a unidade do instante". ${ }^{112}$ No caso da fotografia de Rubens, o recurso à duplicação não só transforma a presença em sequência como cria um jogo de duplo simulacro do real ao se dilatar no tempo. 
casa verde (1997) 
Em seus deslocamentos por São Paulo, simultaneamente à concepção inicial dos huecos, Rubens realiza casa verde, uma intervenção arquitetônica na cidade, neste caso concebida diretamente como fotografia. Em 1997, o artista registrou o resultado da demolição de uma construção, aparentemente residencial, no bairro tradicional da zona norte. À primeira observação da imagem, vê-se uma edificação parcialmente demolida, cujos destroços permanecem ao seu redor, conferindo-lhe um aspecto de ruína. Porém, num olhar mais atento sobre aquela fotografia, percebe-se um certo "arranjo" formal da destruição, pelo qual as paredes internas foram suprimidas, restando apenas sua "casca", que emoldura a paisagem da cidade.

\section{FOTOGRAFIA COMO FORMA E ESPAC̣O}

No enquadramento daquela situação "em demolição", o artista centralizou a posição da edificação no campo visual da fotografia, de modo que a "janela" se colocasse de frente para o observador, abrindo-se à vista da cidade. Além disso, o formato horizontal do vazio também ajuda a valorizar a paisagem. Percebe-se que a imagem foi rigorosamente estruturada. No catálogo da exposição básculas (primeira individual do artista, realizada na Casa Triângulo), há uma foto da construção antes da ação de demolição; nota-se que dela fazia parte um alpendre lateral que foi igualmente suprimido, alterando a forma geral da casa pela qual o artista alcança a simetria das proporções idealizada, demonstrando o quão rigoroso era a construção desse enquadramento físico e imagético (fig. 6).

Essa simetria do novo volume arquitetônico se replica na escolha de Rubens pelo formato final da imagem, quadrado. ${ }^{113}$ Este recurso formal foi nomeado

113 O formato quadrado será uma opção constante em suas fotografias. Segundo o artista, a prefer̂ncia pelo proporção quadrada remete a uma câmera de plástico Kodak formato 127 , de ne a privo ferencia pela proporçá quadrada remete a una cam quadrado, que ele teria ganhado de seu pai aos 14 anos. (Informaçoes extraidas durante a entrevista com o artista em seu ateliê, São Paulo, 3 de agosto de 2015.) 

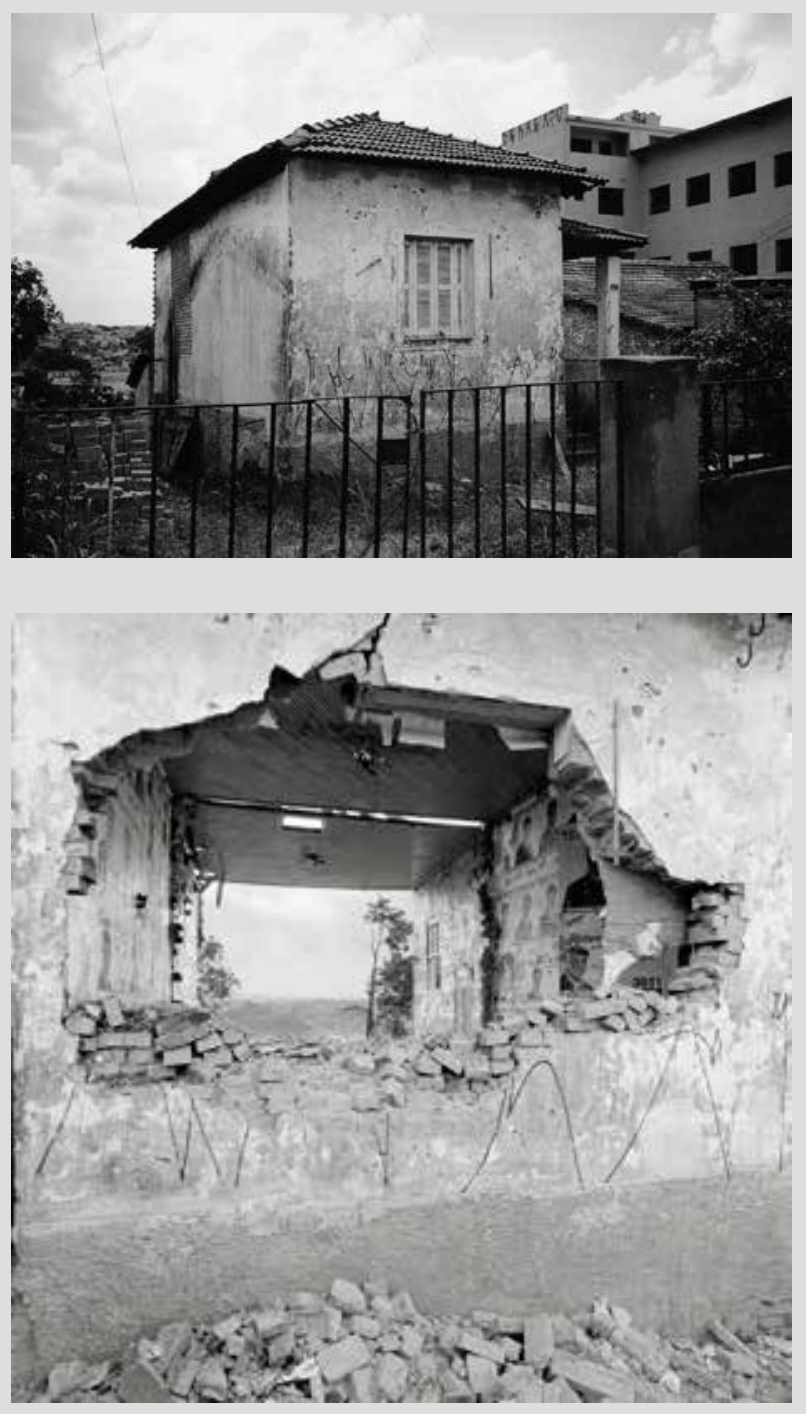

\section{FIG. 6}

Registro da situação encontrada pelo artista antes da intervenção. Av. Casa Verde, São Paulo. Foto: Rubens Mano.
FIG. 7

Registro do processo de demolição das paredes da edificação coordenado pelo artista. Foto: Rubens Mano. por Rosalind Krauss como "aliteração visual”, em que as proporções formais dos elementos que compõem a fotografia estão em consonância morfológica com sua estrutura, ou seja, há um alinhamento entre a forma da construção e a forma da imagem. ${ }^{114} \mathrm{~A}$ estrutura visual montada pelo artista objetualiza a paisagem através da janela da construção (horizontal), ao mesmo tempo que essa construção é codificada pelo formato da fotografia (quadrado).

Além disso, a frontalidade da cena construída por Mano na imagem de casa verde convoca o olhar corriqueiro de quem circula pela cidade e não percebe a paisagem que se apresenta transversalmente ao fluxo contínuo de ruas e avenidas. Porém, diferentemente da sutileza da intervenção nos bueiros, aqui a ação de demolição é em si monumental, e como tal, sua escala é ainda mais acentuada pelo enquadramento frontal da cena (o que talvez explique o porquê da ação ter sido projetada apenas como fotografia, apaziguando a dimensão monumental daquela no intuito de se manter silenciosa). (fig. 7)

Tanto em casa verde como em bueiro, ao transportar a ação para a fotografia, colocando-a como centralidade da cena, Rubens propõem uma espécie de dilatação espaço-temporal do lugar da ação, promovida pela apreensão de um segundo momento da construção espacial, imageticamente. Esse prolongamento espaço-temporal é possibilitado pela construção de um vazio na área central da fotografia, por meio do qual o observador é convocado a adentrar o interior do campo imagético. Para além da edificação, em casa verde avista-se a cidade e tudo o que antes da demolição não era passível de ser percebido.

A construção desse (novo) espaço negativo, seja pela subtração da parte interna do edifício (em casa verde) ou pela anulação do vazio com luz branca (em bueiro), é o artifício criado pelo artista para capturar o olhar do observador e desviá-lo de suas condicionantes cotidianas na cidade, fazendo-o perceber e experimentar outros lugares e de outras maneiras (a dupla construção espacial altera a percepção normatizada do sujeito diante da cidade). Entre

114 Krauss, op. cit., p. 108 
demolição e construção, o resultado é a ressignificação do espaço observado por meio da foto.

A transposição da ação em imagem é conceituada por Mano em sua dissertação de mestrado como um desbordamento. Segundo o artista, este seria:

uma "zona de contaminação" onde as fotografias aparecem como um "corte de narrativa" aplicado sobre o lugar - que incide sobre a transformação da imagem em espaço, e onde as inserções realizam um "corte na narrativa” mantida pelos fluxos que constroem a paisagem, revelando imagens que supostamente já pertenceriam ao lugar..$^{115}$

\section{A FORMAÇ̃̃ DA CIDADE, RASTROS}

Do ponto de vista da alteração da percepção da cidade, casa verde convoca a um olhar sobre a paisagem do bairro e sobre sua condição espacial urbana, cujo ponto de vista dificilmente é apreendido numa cidade tão construída e verticalizada como São Paulo. ${ }^{116}$ Nos situamos no lugar a partir do título do trabalho, que corresponde à avenida principal do bairro. A escolha do local é certeira: desde sua fundação, a Casa Verde desfruta de uma condição topográfica privilegiada na capital paulista. Do alto da avenida, a "nova" construção desponta como um mirante. Para além de se localizar geograficamente, o observador é levado a ressignificar aquele lugar no imaginário da formação da cidade sob dois aspectos: por sua condição topográfica ("São Paulo é um mar de morros", como dizia o geógrafo Aziz Ab'Saber), ${ }^{117}$ e pelas ruínas decorrentes dos resíduos de demolição.

115 Mano, op. cit., 2003, p. 24

116 O desejo latente de se avistar a cidade tem transparecido com frequência na arte contemporânea por meio do uso de escadas, mirantes, janelas, dispositivos que estendem a capacidade dos olhos de ver (e do corpo, de sentir) para além dos constructos materializados pela arquitetura.

117 A declaração do professor e geógrafo Aziz Ab'Saber foi dada durante aula inaugural da Escola da Cidade, em 2002, onde cursei a graduação em Arquitetura e Urbanismo durante sete anos.
Ouanto ao primeiro aspecto, se tomarmos casa verde como um mirante, o elemento construtivo concebido pelo artista e registrado em fotografia funcionaria como um dispositivo para dissolver o edifício na paisagem da cidade de São Paulo, anulando sua densa verticalização, por meio do qual restitui o ponto de vista primordial da formação de morro do território.

Para se investigar essa condição topográfica da cidade, que remonta ao seu sítio primordial, além de Ab'Saber, outros autores ajudam a reconstituir os rastros da configuração paulistana de morros e entender como os desníveis foram vencidos pela arquitetura. Em seu livro São Paulo: razões da arquitetura, ${ }^{118} \mathrm{o}$ arquiteto Angelo Bucci elege uma situação exemplar da cidade (um desnível topográfico) para analisar a "vocação paulistana" do mirante, desde suas origens:

Mirante é característica da geografia do patamar de terra firme, disposto vinte metros acima da várzea do rio Tamanduateí, no qual se implantou a vila jesuítica há cinco séculos inaugurando a cidade de São Paulo. Era, então, uma implantação encastelada, introvertida, quando a encosta servia como barreira de defesa, e o mirante, como um recurso para os olhares de vigia. O vale do Tamanduateí, quando visto em secção transversal, mostra-se assimétrico. A encosta que assinala o final da colina histórica, à sua margem esquerda, não ressurge na margem direita onde a várzea se estende folgadamente. Por isso, quando da margem direita se olha a colina, destaca-se a imponência da encosta e, em sentido oposto, do alto do patamar, a condição de mirante - potencial - é acentuada pela extensão da vista. ${ }^{1{ }^{19}}$

118 No livro, o autor investiga estratégias arquitetônicas de como "atravessar paredes"; mirar, transpor, invadir e infiltrar são anunciadas como quatro imagens, ou açōes, que por sua vez sustentam quatro operaçōes características da dinâmica paulistana. Cf. Bucci, Angelo. São Paulo, razões da arquitetura: da dissolução dos edifícios e de como atravessar paredes. São Paulo: RG Bolso, 2015 119 Ibidem, p. 115. 
Além das reminiscências da formação primordial daquele lugar, casa verde traz uma São Paulo representada como ruína, o segundo aspecto da formação da cidade ao qual a fotografia-intervenção de Mano remete.

Os processos de demolição na paisagem da cidade é algo que Mano vinha perseguindo há tempos, e faz parte do imaginário paulistano. Desde sua fundação, São Paulo vive em permanente demolição. Como diz o poeta "Tudo parece/Que era ainda construção/E já é ruína”. ${ }^{120}$ Em casa verde, a ruína remonta a uma tipologia arquitetônica de traços neocoloniais, que constituiu a morfologia urbana no início da formação da metrópole (composta em geral por edificações ensimesmadas típicas da herança portuguesa e que resultaram num skyline horizontal do seu entorno por décadas), e que foi pouco a pouco substituída por uma nova imagem de cidade, densamente construída e simultaneamente em ruína.

Segundo a urbanista Sarah Feldman, o binômio demolição-reconstrução sempre foi a lógica dominante na configuração da capital paulista. ${ }^{21}$ Sob o paradigma da cidade moderna, na primeira metade do século $\mathrm{XX}$, a vila de São Paulo se ergueu conduzida pela ideologia "haussmaniana" do prefeito Prestes Maia, que coadunava com a política varguista de racionalização e montagem institucional, a qual teria lançado as bases da metropolização no país. ${ }^{122}$ Particularmente, a primeira gestão de Prestes Maia, entre 1938 e 1945, tinha implantado o modelo expansionista, rodoviarista e verticalizador, projetado no Plano de Avenidas, cujas diretrizes se afirmariam nas décadas seguintes.

A opção pela verticalização não é exatamente condição sine qua non da urbanização das cidades, como pondera Sylvia Ficher, mas uma opção empreendida pela política urbana brasileira.

120 Trecho da letra da canção"Fora da ordem", de Caetano Veloso.

121 Feldman, Sarah. Patrimônio cultural e a dimensão metropolitana. Cymbalista, Renato; Feldman Sarah; Kühl, Beatriz (orgs.). Patrimônio cultural: memória e intervençōes urbanas. São Paulo: Fapesp/ Annablume, 2017, p. 226.

122 Campos; Gama; Sacchetta (orgs.), op. cit., p. 99.
São Paulo é o grande ícone desse fenômeno, que só adquiriu proporções de peso a partir das décadas e 1960 e 1970. Antes disso, entretanto, os edifícios altos e áreas verticalizadas constituíram toda uma simbologia que tem o seu espaço na própria história da cidade, associados à ideia de modernização, de progresso e aos êxitos econômicos da metrópole ${ }^{123}$

, ainda que esses exemplares verticalizados fossem restritos às zonas centrais até esse período.

Ao mesmo tempo, a orientação rodoviarista de Prestes Maia, que implementou grandes avenidas e vias arteriais, privilegiou a circulação na cidade via transporte sob pneus, desqualificando as escalas do pedestre, dos encontros fortuitos e da vida pública por extensão. Em decorrência, para o historiador da arquitetura Candido Malta Campos, a política modernizante do prefeito teve um caráter limitado: "a modernização empreendida por Prestes Maia foi portadora de uma racionalidade distorcida e desprovida de qualquer traço socializante mais efetivo; portanto bastante diferenciada da modernização idealizada pelo movimento moderno de então". ${ }^{124}$

Para a teórica e semiologista Lucrécia Ferrara, apesar de distantes no tempo, os anos 1990 se mostraram mais parecidos com a década de Prestes Maia do que imaginamos. As políticas de urbanização foram pautadas pelas operações urbanas, via parcerias público-privadas, que destruíram bairros inteiros em favor da ocupação do solo e da venda de potencial construtivo, sem se importar com a requalificação desses lugares em termos urbanísticos e de sociabilidade, ${ }^{125}$ a exemplo dos projetos Nova Faria Lima, Água Branca e Águas Espraiadas.

123 Ficher, Sylvia. Edifícios altos no Brasil, Espaço\&Debates, n. 37, 1994, p. 61

124 Campos; Gama; Sacchetta (orgs.), op. cit., p. 111

125 Cf. Ferrara, Lucrécia d'Alessio. São Paulo, Brasil: da imagem local à identidade global. Souza, Maria Adélia Aparecida de et. al. (orgs.). Metrópole e globalização: conhecendo a cidade de São Paulo. São Paulo: Cedesp, 1999, pp. 42-56. 
De par com as novas estratégias que passam a pautar a gestão da cidade a partir desta década, a arquiteta e filósofa Vera Pallamin lembra que a orientação econômica da produção cultural do período também influencia pesadamente as políticas urbanas que passam a se preocupar com a construção de uma imagem de cidade que possa ser competitiva no novo jogo entre as cidades globais:

A "funcionalização" da cultura incidiu diretamente sobre programas e políticas urbanas que chegaram às metrópoles brasileiras no início dos anos noventa, sendo orientadas por experiências realizadas em centros norte-americanos e europeus, com primazia para Barcelona. Será neste momento que passaremos a enfrentar a ideologia do trato desta cidade como uma "empresa competitiva", a confrontar as Operações Urbanas e seus negócios imobiliários sustentados por parcerias entre o setor público e o setor privado - com notáveis ganhos para este último, as iniciativas de "renovação urbana" ancoradas na ideia de urbanismo "reparador", a uma onda de programas de investimentos em centros históricos financiados por empréstimos internacionais [...], substituição de suas atividades por outras mais rentáveis e afastamento dos seus residentes pobres. Em poucos anos vimos uma leva de projetos urbanos que, sob o formato de novas narrativas para o antigo tema da "volta à cidade", favoreceram o reajuste dos modos de renda fundiária às novas exigências e possibilidades de ganhos financeiros. ${ }^{226}$

Portanto, a partir dos anos 1990, a obsolescência da vocação industrial modernizante da capital paulista, econômica e urbanisticamente, passa a conviver com elementos da "cidade mundial" inserida na economia global, e

126 Pallamin, Vera. Percepçōes e intervençōes na metrópole: a experiência do projeto Arte/cidade em São Paulo (1994-2002), Risco, PPGAU EESC-USP, n. 42, 2006, p. 151. seu desenvolvimento passa a ser orientado pelos interesses econômicos que seguiram os vetores da globalização.

É nesse contexto que, segundo Ferrara, a cidade começa a viver o choque entre o local e o global:

Em uma localização da globalização não se pode negar as metáforas mundiais do progresso e modernidade, tais como a verticalidade, a velocidade, as grandes artérias impregnadas de movimento e apropriação anônima, mas se esse é o imaginário que corresponde à globalização, a localização realista do global impõe o enfrentamento do reverso local daquelas metáforas. ${ }^{127}$

Sob o estigma da maior metrópole moderna brasileira, oscilando eternamente entre o destruir e o reconstruir, São Paulo se apresenta como território impreciso, informe e sem referenciais na paisagem.

Sem marcas proeminentes que a notabilizem por um padrão turístico natural, ou construído e marcado por claras referências históricas, São Paulo apenas se expande, cresce, desdobra-se sem emblemas e sem códigos. Ou melhor, se tiver uma referência, ela é construída pelo seu incessante construir que supõe a experimentação e a produção de novos espaços sobre os antigos; ou seja para São Paulo, construir é desconstruir-se enquanto implosão do antigo, do passado, mas sem projeto, sem desígnio. ${ }^{128}$

Em casa verde, é como se Mano buscasse subverter as razões da lógica imanente (moderna) da capital a partir da arte.

27 Ferrara, op cit. 1999 . p. 55

128 Ibidem, p. 43. 


\section{A CONSTRUÇÃO POR SUBTRAÇ̃̃O}

A natureza da fotografia não é senão o índice de algum lugar, coisa ou fato ocorrido, tal como enunciado nas acepções teóricas de Krauss. Aqui, a fotografia nos dá indícios de que a ruína não é propriamente uma destruição, mas uma construção por subtração. A situação não foi encontrada ao acaso na paisagem da cidade, mas foi construída física e simbolicamente pelo artista. É como se tivéssemos a construção de uma dupla janela; uma física, outra imagética. Em casa verde, Mano acumula dois procedimentos de sua prática artística: o construtivo e o fotográfico. Tanto a ação como a imagem transformam aquela paisagem, o que significa dizer que ambas têm a mesma importância para a constituição do trabalho.

Os destroços da edificação que restaram no lote indicam que ali se processa uma demolição, que poria abaixo uma antiga construção num futuro breve Do que lhe resta erguido, sua arquitetura vernacular paulista é revelada pelas configurações longitudinais do terreno, pela implantação com recuos no lote e pela forma que ainda resiste da edificação - tipologia térrea, com piso elevado, alpendre lateral, conformação do telhado em 4 águas, telhas de barro, forro de estuque, entre outros sinais dos tempos. Uma história que aos poucos vai se apagando na cidade e de que a ruína deixa apenas resquícios dela no território. Como comenta o crítico de arte Lorenzo Mammì, "uma construção em ruínas é uma construção que não consegue mais estancar o tempo". ${ }^{229}$

Em casa verde, o entorno da ruína é propositalmente enquadrado na fotografia e ajuda a contextualizar o lugar. Além da "nova" arquitetura subtrativa de Mano, há outros indicadores de transformação na vizinhança: do lado esquerdo, o barracão de madeirite sugere uma nova construção por vir; em ambos os lados, não há limites que determinam onde termina um lote e começa outro.

129 Mammì, Lorenzo. Evento acha cidade morta dentro da cidade atual. Ferreira, Gloria (org.). Crítica de arte no Brasil: temáticas contemporâneas. Rio de Janeiro: Funarte, 2006, p. 482. (O artigo foi publicado originalmente no jornal Folha de S.Paulo, em 20 nov. 1997)
A atividade de demolição geralmente é desempenhada por empresas especializadas. Aqui, o artista incidiu sobre o processo de trabalho comumente executado pela engenharia civil ao alterar as etapas do desmanche. Segundo depoimento de Mano, houve uma negociação entre ele e a empresa responsável pela demolição, por meio da qual o artista pôde orquestrar o início da derrubada da edificação pelas paredes internas, criando-se um grande eixo longitudinal em relação ao terreno, e transversalmente à paisagem da cidade imediatamente atrás da edificação. A alteração no processo de demolição pelo artista conduziu a uma nova "edificação" no lote, por meio de uma construção negativa.

[...] com a remoção de três paredes que dividiam o interior de uma casa (no sentido longitudinal), pretendi o deslocamento do eixo visual inicialmente orientado por ruas e avenidas, a abertura do espaço para algo além do já construído. uma ação "libertadora" de outras imagens pertencentes à paisagem, "descoladas" dentre as tantas sobrepostas. ${ }^{330}$

O esforço "libertador" de Rubens em tornar visível outras camadas da paisagem urbana, sobrepostas pelo acúmulo de ocupações desordenadas no tempo sobre o território, só foi possível graças à esperteza do artista em negociar com a empresa de demolição, que concordou em seguir as orientações daquele para a derrubada das paredes frontal, posterior e internas da casa, antes de pô-la completamente abaixo. O artista, assim, altera a atividade demolidora recorrente e faz dela uma pequena ação subversiva no funcionamento da cidade e na sua morfologia.

30 Mano, op. cit., 2003, p. 30. (Para todas as ocorrências de citaçōes textuais de Rubens Mano, adotou-se a escrita do artista, cuja grafia usa apenas minúsculas; para os inícios de frase no meio do parágrafo, ao invés da letra minúscula, o artista utiliza três espaços para separar uma frase da outra.) 


\section{ESPACOS RESIDUAIS}

A construção subtrativa é uma das respostas que Rubens Mano dá aos processos de demolição na paisagem da cidade, perseguidos há tempos, conforme relatou o artista, e que está fortemente presente no imaginário e na experiência paulistanos. Guardadas as devidas proporções, tanto o interesse por situações urbanas residuais, produzidas pela modernidade, quanto a estratégia de uma prática subtrativa aproximam Mano do artista norte-americano Gordon Matta-Clark. No primeiro caso, essas situaçoes foram impulsionadas pela lógica da própria cidade, uma lógica que tem se propagado no tempo desde sua fundação (o tal binômio demolição-construção). No segundo caso, elas são fruto de um processo de reconfiguração urbana da cidade de Nova York, vivenciado fortemente entre os anos 1960 e 1970 sob o comando do engenheiro Robert Moses, ${ }^{131}$ em que bairros inteiros foram postos abaixo para dar vazão à construção de grandes eixos viários.

Ao longo dos anos 1970, o artista nova-iorquino realizou diversas ações e intervenções no espaço urbano em reação ao impacto vivenciado por ele na sua cidade natal, cujos registros fotográficos e fílmicos são hoje os meios para conhecê-las. Elas contêm um forte caráter estético-político, expresso desde os trabalhos "city-related" (a exemplo das ações clandestinas em Pig Roast $e$ Fresh Air Cart), passando pelos extratos de construções deterioradas no seu entorno (como Bronx Pieces) (figs. 8 e 9), até as fendas subtraídas de edificações abandonadas (a exemplo de Conical Intersect) (fig. 10), as quais representam a sua maturidade anarquitetônica.

131 O engenheiro Robert Moses (1888-1981) foi responsável pela reorganização metropolitana da cidade de Nova York entre os anos 1950 e 1970 . Sem nunca ter assumido um cargo político, ele promoveu a abertura de malhas viárias na cidade, por meio da destruição de bairros inteiros, como o Bronx, ea consequente gentrificação de zonas ao sul da ilha.
É preciso lembrar que ambos os artistas tiveram uma formação universitária em Arquitetura e Urbanismo, ${ }^{132}$ cujos referenciais estão fortemente presentes nas suas proposições artísticas. A partir dessa matriz comum, se para Mano a experiência da cidade foi impulsionada pelo olhar da fotografia e pelos percursos investigativos proporcionados pela prática jornalística, no caso de Matta-Clark suas intervenções urbanas foram mobilizadas pelo forte impacto vivencial da política urbana de Moses - que derrubou dentre outros distritos o Bronx e o Soho, nos quais o artista atuou - e influenciadas pela dança-performance de Trisha Brown, pela qual o envolvimento corporal do artista na realização de suas intervenções urbanas adquiriu um forte caráter performativo.

Fica claro que, desde casa verde, as escolhas de Mano pelos lugares em que realiza suas intervenções não se explicam por laços afetivos diretos, mas por curiosidades e descobertas anônimas no território. No caso brasileiro, portanto, a construção de lugares se caracteriza por seus aspectos relacionais e históricos, nos termos de Augé, mais do que identitários. Diferentemente, as primeiras "dissecações" arquitetônicas de Matta-Clark elegem o entorno habitado pelo artista como desafio (a exemplo do Soho, bairro onde passou boa parte de sua vida artística), num ato de desobediência civil diante dos processos de gentrificação dos anos 1960 e 1970, atravessado por um caráter ativista que envolvia por vezes a comunidade local. No artista norte-americano sobressaiam os aspectos identitários e relacionais, mais do que propriamente históricos.

Sabe-se que o interesse por esses espaços residuais vem desde pelo menos os surrealistas e passam, como visto, pelos percursos pelo subúrbio realizados por Smithson nos anos 1960 e pelas práticas subtrativas anarquitetônicas de Matta-Clark, nos anos 1970

132 Como já mencionado na Introdução desta tese, Mano se formou na Faculdade de Arquitetura e Urbanismo de Santos, em 1984, enquanto Gordon Matta-Clark estudou na Cornell University, entre 1962 e 1968. 

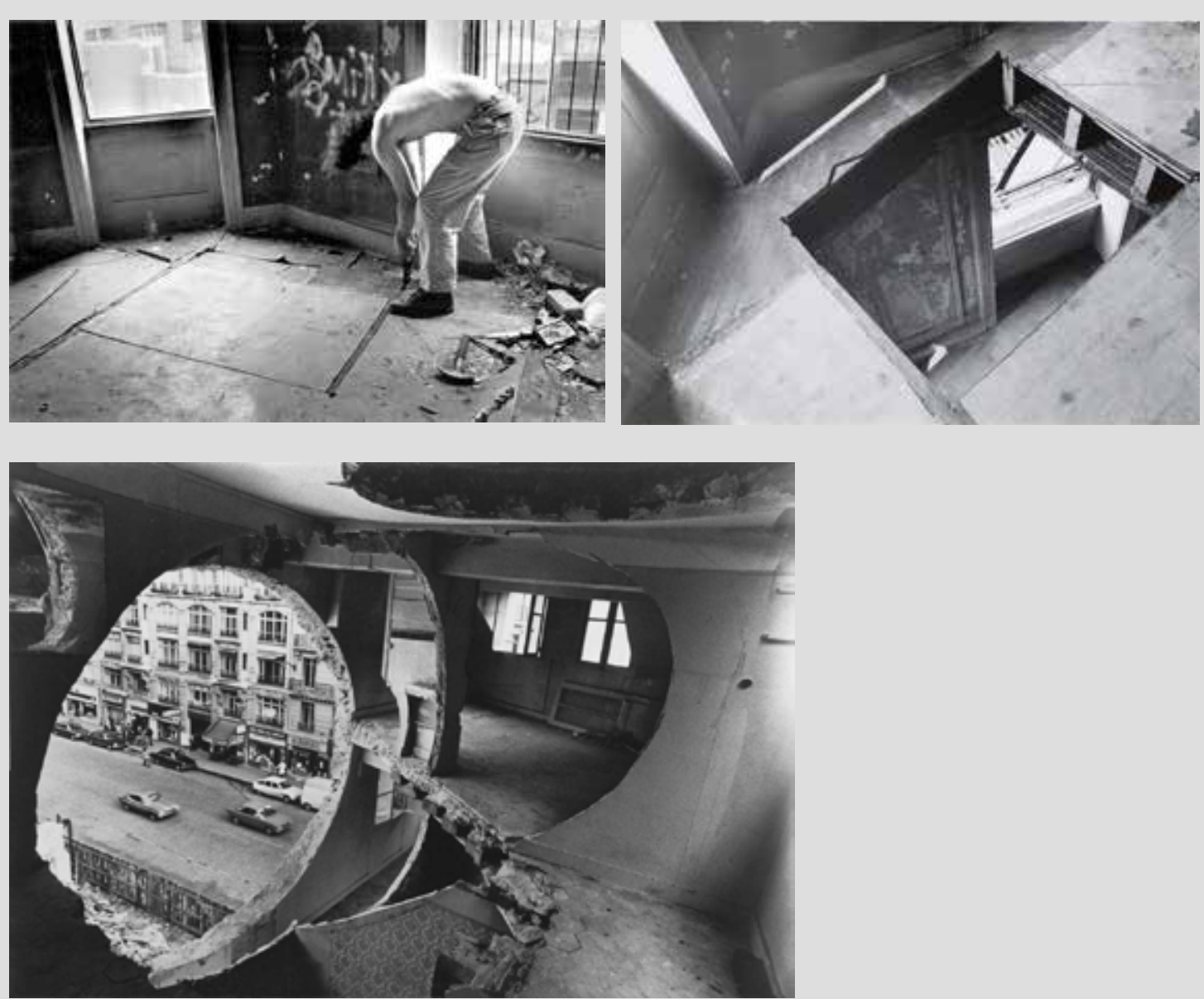

FIG. 8 Gordon Matta-Clark.

Bronx Floors, 1972

Foto: The Estate of Gordon Matta-

Clark/Courtesia The Estate of Gordon

Matta-Clark and David Zwirner, New

York/London (acima à esquerda)

FIG. 9 Gordon Matta-Clark.

Bronx Floor, 3A, 1973

Fotografia, impressão em gelatina

de prata, $15,9 \times 23,2 \mathrm{~cm}$

Succession de Gordon Matta-Clark en

dépôt au Centre Canadien d'Architecture,

FIG. 10 Gordon Matta-Clark. Conical

Intersect, 1975

Fotografia, impressão em gelatina

de prata, $27 \times 39,7 \mathrm{~cm}$

Coleção San Francisco Museum

of Modern Art
Em 2013, Rubens participa da mostra Lugarnenhum, realizada no Instituto Moreira Salles do Rio de Janeiro, onde expõe a obra casa verde e uma série de fotografias de ruínas. Nela, justamente, os curadores Lorenzo Mammì e Heloisa Espada exploraram o interesse recorrente da arte por espaços residuais (ao qual pode-se incluir edificações abandonas e terrenos baldios), e que aparece de modo intermitente ao longo da arte moderna e contemporânea. No texto publicado no catálogo, Mammì e Espada recuperam a centralidade que a obra Os monumentos de Passaic, de Smithson adquiriu para a temática dos espaços residuais na arte, e expõem o impacto que tais espaços tiveram não só na arte, mas também na arquitetura:

a valorização de espaços urbanos inertes como lugares culturalmente relevantes - justamente por suspenderem todo significado prévio e se deixarem atravessar por muitos sentidos possíveis - teve consequências notáveis, tanto na arte como na teoria da arquitetura e do urbanismo. ${ }^{133}$

Os fundamentos curatoriais de Mammì e Espada também se basearam no artigo "Terrain vague", de Solà-Morales. Segundo este, é justamente entre o final da década de 1960 e o início de 1970 que se inaugurava uma "sensibilidade distinta que começava a desprender uma mirada diversa às grandes cidades" ${ }^{134} \mathrm{O}$ olhar do fotógrafo urbano passou a se interessar pelos espaços vazios e abandonados, nos quais já havia sucedido uma série de acontecimentos.

São os lugares urbanos, que queremos denominar com a expressão francesa terrain vague [terrenos baldios], os que parecem se converter em fascinantes pontos de atenção, nos indícios mais solventes para poder se referir à cidade, para indicar com as imagens o que as cidades

133 Mammì e Espada, op. cit., p. 8

34 Solà-Morales, op. cit. 
são, a experiência que temos dela. Como em todo produto estético, a fotografia comunica não só as percepções que desses espaços podemos acumular, mas também as afeiç̃es, ou seja, aquelas experiências que do físico passam ao psíquico convertendo o veículo das imagens fo tográficas no meio através do qual estabelecemos com esses lugares, vistos ou imaginados, um juízo de valor. ${ }^{135}$

A problematização desses lugares baldios e relegados na cidade foi captada em fotografia por diversos artistas contemporâneos, a exemplo de John Davies, David Plowden, Thomas Struth, Jannes Linders, Manolo Laguillo e Olivio Barbieri, citados por Solà-Morales, ao qual também se pode incluir Rubens Mano. Segundo o historiador espanhol, suas ocorrências na cidade apontam para seu esquecimento histórico e seu abandono funcional. Depois de usurpá-los por décadas, tornam-se obsoletos. São lugares onde a memória do passado predomina sobre o presente; mas é uma memória imprecisa, uma vez que seu aspecto geralmente ruinoso desfez parte da história. São lugares obsoletos onde restam apenas valores residuais.

Do ponto de vista econômico, esses terrenos estão fora dos circuitos e das estruturas produtivas (tais como áreas industriais, estações de trem, portos, bairros inseguros, lixões), o que acaba convertendo o seu entorno em "áreas urbanizadas sem cidade". Sobre esses terrainsvagues, Solà-Morales complementa:

são suas bordas carentes de uma incorporação eficaz, são ilhas interiores esvaziadas de atividade, são restos que permanecem fora da dinâmica urbana. Convertendo-se em áreas simplesmente des-habitadas,

135 Ibidem. Além disso, o autor explica que a expressão francesa terrain vague tem um caráter eminentemente urbano. Em primeiro lugar terrain designa uma extensão de solo de limites precisos, edfićvel,

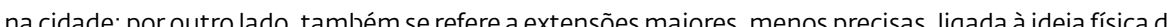

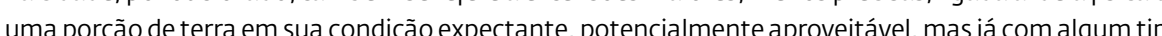
de definção em sua propriedade a qual somos aheios. Além disso, o termo vague tem duas acepōes na língua francesa, a de "vazio", como lugar desocupado, e a de"vago", como lugar impreciso, indefinido. in-seguras, im-produtivas. Em definitiva, lugares estranhos ao sistema urbano, exteriores mentais no interior físico da cidade que aparecem como contraimagem da mesma, tanto no sentido de sua crítica como no sentido de sua possível alternativa. ${ }^{136}$

Em meados dos anos 1990, assim, casa verde emerge como mais uma dessas percepções sobre o território em transformação, em que o artista revela a metamorfose permanente do real, sob o ponto de vista específico da lógica da cidade paulistana - de construção-desconstrução-construção. 
entre (2003)

súbitas paisagens (2006-07) 
Em seus percursos pela cidade de São Paulo, Rubens Mano se depara com a ruína em diferentes situações na paisagem urbana - desde regiões centrais mais degradadas a zonas de fronteira, que fazem a transição entre a área urbanizada e a área "rural". Essas bordas da cidade estão repletas de construções abandonadas, que frequentemente passam despercebidas aos olhos de quem circula pela região. Ao perceber tal situação, Mano elege um fragmento de paisagem em ruína à beira de uma das saídas da capital paulista para construir mais uma de suas proposições fotográficas. No díptico entre, de 2003, o artista registrou uma pequena casa abandonada cercada pelo mato que cresceu espontaneamente ao redor. A única abertura na fachada da casa está preenchida de cor, respectivamente de verde e de rosa (em cada uma das fotos do díptico). Como num jogo de 7 erros, num primeiro olhar identificamos cenas idênticas, porém logo as duas cores que preenchem o vazio das janelas não nos deixam enganar sobre a sutil variação da composição.

A imagem da natureza vegetal que cresce ao redor de um "objeto" construído pelo homem e que invade suas entranhas nos reporta novamente às origens da ideia da ruína urbana produzida pela modernidade. No livro Paisagens urbanas, Nelson Brissac Peixoto dedica um capítulo às ruínas; nele, recorre a uma fotografia anônima, publicada na revista surrealista Le Minotaure, em 1937 (fig. 11), para discorrer sobre a ideia da ruína urbana moderna em sua origem. Na fotografia surrealista, há uma locomotiva desativada totalmente envolta pela natureza "selvagem", que tomou conta do objeto e seu entorno. Assim como Ignasi de Solà-Morales, Peixoto também considera que os surrealistas foram pioneiros em olhar a ruína urbana com interesse: os surrealistas foram os primeiros a perceber as energias revolucionárias contidas naquilo que é obsoleto, nas primeiras construções de ferro, nas primeiras fábricas, nas fotografias mais antigas, nos objetos que começam a cair em desuso" ${ }^{137} \mathrm{Na}$ foto de 1937 , a inércia da locomotiva não é senão a

Peixoto, Nelson Brissac. Ruínas: o essencial ainda está por vir. Paisagens urbanas. São Paulo: Senac, 2004, p. 280 

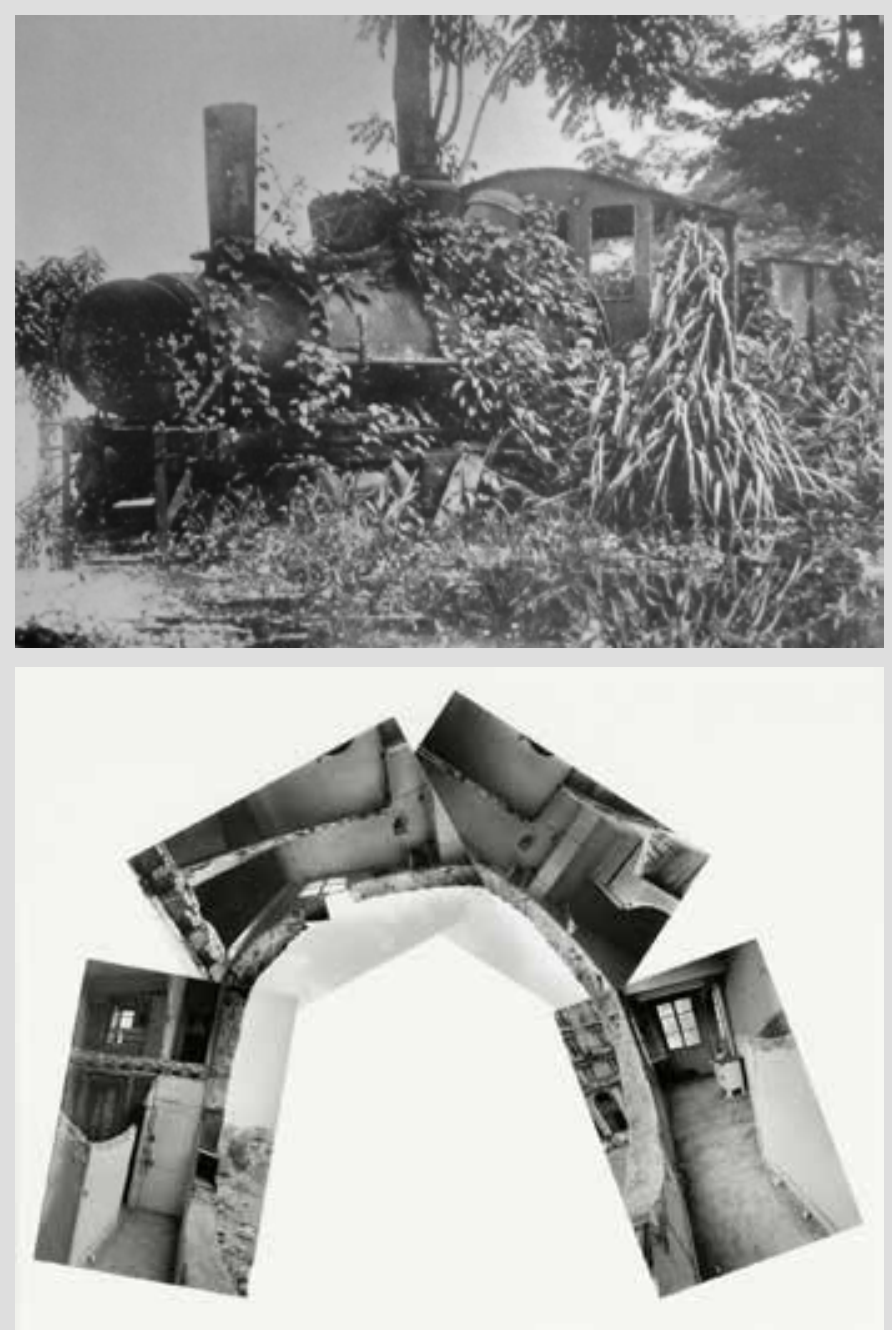

alegoria da velocidade truncada. "A natureza aqui é vital, embora inercial: cresce mas só para devorar o avanço do trem, ou o progresso que ele um dia emblematizou". ${ }^{138}$

A cena da locomotiva de alta velocidade abandonada aos delírios da selva expressa uma situação em que as promessas de futuro foram convertidas em pretérito, donde a fotografia é a melhor alegoria para representá-la: um verdadeiro registro fúnebre da modernidade. Como aponta Rosalind Krauss, ao analisar a mesma fotografia surrealista referida por Brissac, "a própria ideia de imobilização do movimento é por si só fotográfica". ${ }^{139}$

No caso de Mano, a mata que cresce ao redor da casinha de beira de estrada, na borda da cidade, é o único resquício de construção humana naquele local. Porém, diferentemente dos surrealistas, para quem a fotografia ajudou a escavar os lugares mais inusitados e remapear a cidade, Rubens aciona a arqueologia daquela construção a partir da introdução de uma cor "artificial", produzida pelo artista. Aparentemente, a presença vibrátil da cor que emana do interior da construção é tão postiça que parece envolver um processo de pós-produção, com uma suposta manipulação digital da imagem depois de feito o registro in loco. Não é esse o caso. A alteração que se apresenta na abertura da janela é fruto de mais uma das intervenções de Rubens - como não poderia deixar de ser -, dessa vez realizada no interior da construção.

Sobre o procedimento operado pelo artista, Heloisa Espada esclarece:

[Rubens] pintou de branco o interior de uma casa abandonada à beira da via Dutra, com exceção da parede com a janela, que foi colorida de verde e, depois, de rosa. Em seguida, fotografou a construção sob sol

FIG. 11 Fotografia anônima, que ilustra o artigo de Benjamin Péret "La Nature dévore le progrès et le dépasse

["A natureza devora o progresso e the ultrapassa"], publicado na revista Le Minotaure, n. 10, Paris, inverno 1937, p. 20.
FIG. 12 Gordon Matta-Clark. Conical Intersect, 1975 Colagem com fotografias. Impressão em gelatina de prata, $26,9 \times 31,7 \mathrm{~cm}$ Coleção MACBA, Barcelona
138 Ibidem.

139 Krauss, op. cit., p. 122 
Em termos formais e de construção da cena, no díptico entre Rubens também dá preferência a enquadramentos frontais e centralizados, ao posicionar a construção e o vazio colorido no núcleo da composição e de frente para o ob servador. Como bem observou Espada, "nessas imagens de abandono e decadência [...] a contundência nasce de um extremo rigor formal em contraste com a precariedade do que está diante da câmera". ${ }^{141}$

Aqui, novamente, podemos tecer comparações entre Mano e Matta-Clark: enquanto nas fotografias do brasileiro o enquadramento da situação urbana obedece a uma frontalidade, organizada simetricamente e cujo centro (onde se deu a alteração da construção e para o qual o olhar converge) é um "vazio", as versões fotográficas de Matta-Clark sobre suas intervenções em edifícios abandonados são geralmente compositivas, por meio da qual o artista busca reconstituir a situação arquitetônica do local, mesmo que ilusoriamente, ao transpô-la espacialmente numa percepção e visualidade fragmentadas (fig. 12). Ao cortar pedaços de pisos e paredes, o espaço que era organizado por planos ortogonais (horizontal e vertical) passa a justapor diferentes planos, obliquamente, e é essa sensação gravitacional instável que o artista parece querer conferir às suas fotomontagens. De volta a Mano, a centralidade do elemento dissonante do campo visual, por meio do qual a atenção do sujeito é captada, confere uma estabilidade ao corpo que a percebe. A concisão é uma de suas qualidades.

O tema da ruína urbana nas proposições de Mano, principalmente naquelas formalizadas em fotografia, reelabora com frequência o convívio entre a vida e a morte, o animado e o inanimado, o histórico e o natural. Além de entre,

140 Espada, Heloisa. Lugar nenhum, Blog IMS. Disponivel em: <https://blogdoims.com.br/lugar-nenhum-por-heloisa-espada/>. Acesso em 1o out. 2017.

141 Ibidem. ela também está presente na série súbitas paisagens, iniciada em 2006. ${ }^{142}$ A série apresenta um "mapeamento" de paisagens em ruína, onde a promessa do novo (neste caso, edificações abandonadas ou inconclusas) convive com uma natureza selvagem. Dentre os trabalhos que a compõe, há fotografias de situações encontradas em suas andanças pelo território paulistano, boa parte delas com edificações inacabadas, restos de canteiro de obra e lugares cheios de entulho.

Dentre as súbitas paisagens, há um curioso conjunto de fotografias tomadas num antigo balneário da Ilha do Mosqueiro, que pertence ao município de Belém do Pará, realizadas por Rubens em 2007. O curador e artista Orlando Maneschy recorda que, nos idos de 1980, o Araçagy Praia Clube era um dos destinos preferidos dos turistas da região. ${ }^{143} \mathrm{Nas}$ fotografias do conjunto, figuram entre outras cenas uma grande piscina vazia em meio à mata amazônica e dois "tobo-águas" serpentinados cercados por arame farpado. Sob o olhar do artista, os elementos arquitetônicos do complexo turístico despontam como trágicas esculturas na paisagem. A ruína dos equipamentos representa a consequência da saída do homem do lugar e da ocupação deste pela vegetação primordial. As imagens de Mano nos reportam à desfaçatez do sonho de verão daquele tempo venturoso.

O rigor formal na ressemantização da ruína urbana em imagem, dado pelo enquadramento simétrico da construção e pela frontalidade da cena, já tinha sido explorado por Mano em várias ocasiões, a exemplo de casa verde e entre. Além destas, em 2001, Rubens realizou o políptico observador (fig. 13), em que também captura uma paisagem construída e inóspita, aparentemen-

142 Naquele ano, o artista foi contemplado com o programa de obras comissionadas da Fundação Cisneros. A bolsa Ihe permitiu desenvolver um conjunto de fotografias desta série que, ao final do programa, foram expostas na mostra dos artistas contemplados pela fundação. A exposição 10 Defining Experiments 2006 CIFO Grants \& Commissions Program Exhibition ocorreu na CIFO Art Space, em Miami. entre outubro e novembro de 2006 .

13 Maneschy Orlando Vetores e experimentações estéticas nas múltiplas amazônias: por uma coleção amazoniana de a te da uFpa. Medeiros, Afonso e Hamoy ldanise (orgs) Anais do $22^{2}$ Encontro da

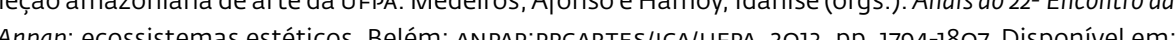
Anpap. ecossistemas rlando\%20Franco\%20Maneschy.pdf $>$. Acesso em 29 dez. 2017. 

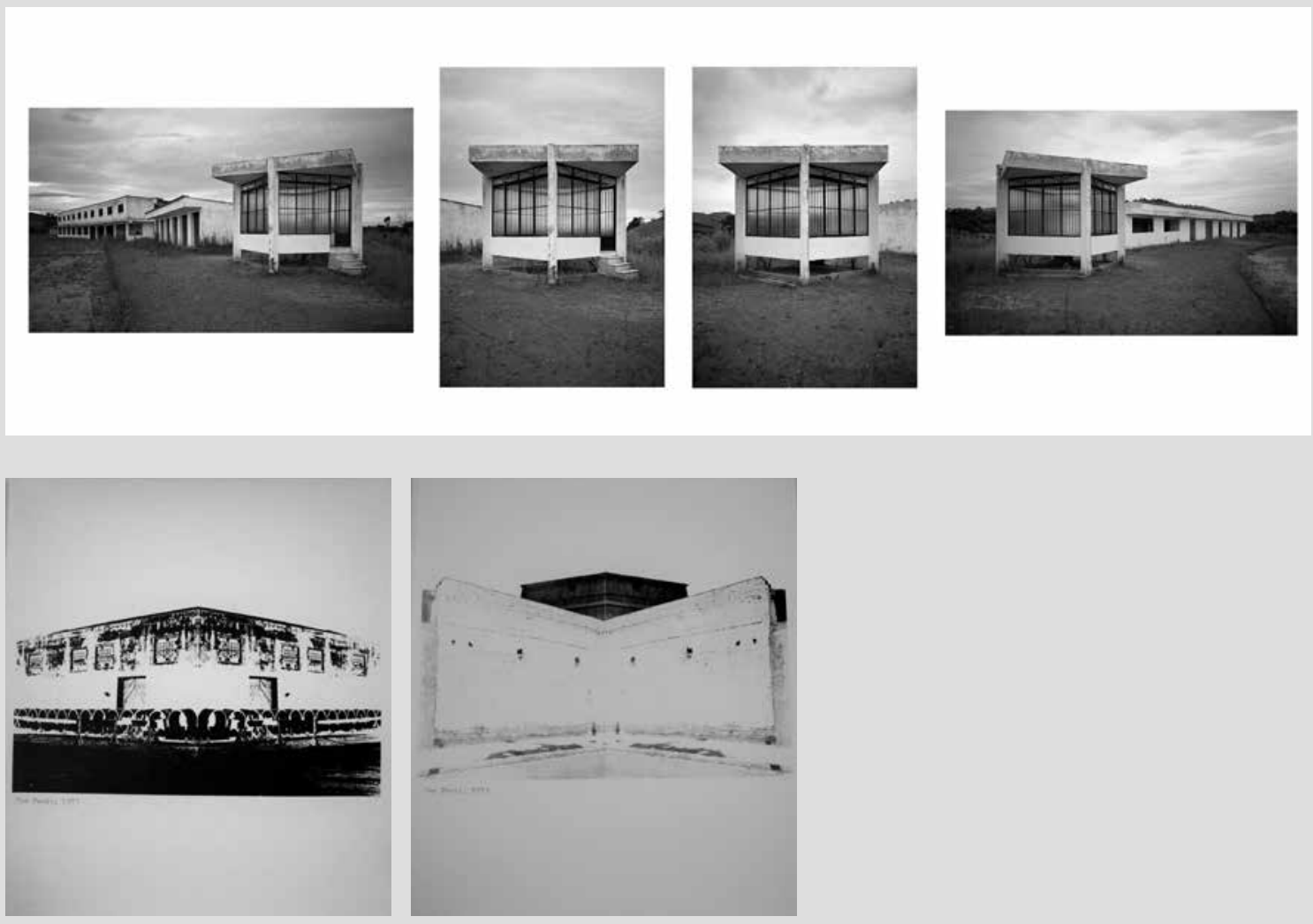

FIG. 13 observador, 2001

Políptico em fotografia, impressão

lambda em papel RC fosco montada em

moldura de madeira, $53 \times 90 \times 3 \mathrm{~cm}$,

$84,4 \times 53 \times 3 \mathrm{~cm}, 53 \times 82 \times 3 \mathrm{~cm}$

FIGS. 14-15 Julio Plaza.

Antifotografias, 1971-73

Álbum constituído por 11 fotografias;

impressão pb sobre papel, $29,2 \times 25 \mathrm{~cm}$

(cada). Coleção MAC-USP. te abandonada. A concepção do políptico a refaz sob a forma de um panorama com quatro partes, que ajudam a reencenar a perspectiva espacial daquela arquitetura monumental e seu isolamento naquele lugar.

A recorrência com que Mano (re)constrói a cena urbana da ruína em suas fotografias com um tal rigor formal nos reporta a um álbum de 11 fotografias produzidas por Julio Plaza entre 1972 e 1975, em colaboração com o artista espanhol José Maria Iglesias (1933-2005). Intituladas Antifotografias (figs. $14 \mathrm{e}$ 15), o conjunto de fotomontagens reencena antigas construções industriais, cujas imagens foram espelhadas e remontadas no eixo central da composição, simetricamente. O conjunto dessas tipologias constitui uma espécie de taxonomia urbana de edificações industriais abandonadas, muitas delas tiradas em São Paulo. A nova volumetria compositiva dessas edificações monumentais resulta numa arquitetura disfuncional e fantasmática, tal como percebemos as estruturas do complexo turístico de Araçagy.

Vale destacar ainda o modo como Rubens agenciou a passagem do tempo retratada nas fotografias da série súbitas paisagens, transformando-a no dado "performático" dos trabalhos. Neles, o tempo é o protagonista anônimo da construção e reconstrução daquele lugar. Como bem observou o curador Cauê Alves, no texto de apresentação da mostra Ouase líquido, realizada no Itaú Cultural em 2006, que incluiu parte da série na exposição, “o tempo [é] o responsável por corroer e dissolver parte do que havia de sólido nessas paisagens". ${ }^{144}$ Algo muito próximo do que Mammì observou no interesse recorrente dos artistas por espaços urbanos inertes, "culturalmente relevantes" por "suspenderem todo significado prévio e se deixarem atravessar por muitos sentidos possíveis".

144 Alves, Cauê (cur.). Quase líquido. (Catálogo de exposição). São Paulo: Itaú Cultural, 2008, p. 66. 


\section{IMAGENS PERFORMÁTICAS}

O conjunto de fotografias aqui analisadas e nomeadas "imagens performáticas" se apresenta como parte da estratégia de Rubens para atuar na cidade, subverter certas estruturas de uso e poder tecidas no espaço urbano, e en volver o seu observador na percepção do espaço ao reportá-lo ao acontecimento da ação/intervenção. Apesar de "congeladas" no tempo, as imagens pressupõem uma duração da ação; no entanto, o autor da ação está sempre fora da cena. No lugar da presença, o artista prefere deixar apenas indícios, tal como a natureza fotográfica.

Nas fotografias de Mano, concebidas entre meados da década de 1990 e meados da de 2000, podemos elencar alguns aspectos singulares que se repetem na concepção rigorosa da imagem e que corroboram para a construção/percepção da cena/lugar: contrastes de luz marcantes, com áreas de destaque no centro da composição, que abririam essas paisagens ao mergulho do olhar; preferência por formatos quadrados, o que supostamente evitaria uma apreensão da obra condicionada pelos formatos derivados dos gêneros pictóricos, do retrato (vertical) e da paisagem (horizontal); enquadramentos de cena geralmente frontal e centralizado, conferindo ao assunto principal uma presença eloquente, num sentido arquitetônico e/ou escultórico "monumental"; aproximação entre o fato registrado e o observador, donde a câmera geralmente é posicionada na escala do corpo; e a ausência de figuras humanas no campo visual; dentre outros.

As ações implicadas no espaço da imagem variam entre mais ou menos evidentes - e marcam uma das principais características do seu trabalho: a condição silenciosa em que se dão suas intervenções. Elas são ora produzi das intencionalmente pelo artista, ora desencadeadas pelas contingências do lugar em questão. No segundo caso, o fato performativo é suscitado pelas relações tecidas na cidade, antes mesmo da concepção da obra; porém, ela só se torna sensivelmente visível através do olhar do artista. Se compararmos lado a lado disponha com bueiros, ou súbitas paisagens com casa verde, veremos que o ato performático é ora processado pelo devir do lugar ora construído pelo corpo do artista no seu espaço de atuação.

Tal constatação vai de encontro ao que Mammì e Espada apontaram como duas situações distintas verificadas nos trabalhos de Rubens:

nos espaços abandonados, lhe interessam os rastros das ações humanas, as tentativas, ainda que frágeis, de mudanças; nos espaços em atividade, a possibilidade de gerar fatos que, ainda que efêmeros, revelam novas possibilidades de percepção e uso. ${ }^{145}$

Na fotografia de casa verde, a orquestração da derrubada comandada por Mano e reconfigurada no enquadramento final da imagem revela um caráter performativo por parte do artista, que, de modo silenciado, deixa pequenos indícios na produção daquele espaço. Diferentemente de Mano, para o qual as ações deveriam ocorrer de forma silenciosa - e só mais tarde, no momento do registro, tornadas públicas-, Matta-Clark procurava alardear a comunidade e o poder local sobre suas ações ativistas, não somente a comunidade local, mas o métier especializado da arte e a mídia em geral.

Neste sentido, para o artista norte-americano, interessava tornar visível os meios, tanto mais que os fins: a ação transgressora de intervir nesses edifícios carregava em si um sentido político sobre aquele lugar, sobre a produção do espaço social daquela comunidade do entorno, e sobre os modos como a cidade o "urbaniza". A cidade mostra-se como lugar potente onde são tecidas formas de coletividade e lutas políticas, ${ }^{146}$ quaisquer que sejam os modos de comunicá-las. Em Matta-Clark, o interesse pelo espaço urbano carrega uma imagem libertária, de caráter utópico, imersa na vertente experimental que assolava a cena nova-iorquina nos anos 1970

No caso de Mano, apesar de os meios interessarem tanto quanto os fins

145 Mammì e Espada, op. cit., p. 15

I 6 Cf Lefètbre, Henri. From The Urban Revolution [1970]. Wood, J. Hulks, D. e Potts, A (orgs.). Modern Sculpture reader. Leeds: Henry Moore Institute, 2007, pp. 297-298. 
nessas obras, como valorização das diversas camadas que os trabalhos envolviam, há uma atenção que se volta especialmente para a camada visível da obra, que é a fotografia, concebida como sua forma final. Apesar disso, o rigor da construção da imagem não se restringe à operação fotográfica em si (como técnica), mas também se nota na própria produção do espaço operada pelo artista e registrada por ele minuciosamente.

\section{A CONSTRUÇÃO DE ESPAÇOS}

Em Mano, a fotografia é construída como uma via de percepção de um acontecimento que se constitui fora do espaço real e do espaço imagético, e que foi formulado como problema por uma ação do artista operada no tempo-espaço da cidade e de sua paisagem. Ao se deslocar por zonas metropolitanas, periféricas e/ou degradadas, o artista elege certos interstícios para sua atuação; as intervenções no espaço revelam outras camadas do lugar, além das que se apresentam na superfície, reconstruídas agora no espaço sensível da arte.

As ações de Rubens no espaço urbano transpostas para o meio fotográfico investigam a natureza do lugar, constituído por seus fluxos, narrativas, dinâmicas e contradições no interior da vida urbana contemporânea. Elas elaboram uma percepção do real por meio da construção de uma segunda realidade, poética, situada entre espaço real e espaço da imagem, entre espaço concreto e espaço abstrato, e, no limite, entre espectador e obra.

Segundo o historiador de arte e curador mexicano Osvaldo Sánchez, ${ }^{147}$ as imagens de cidade produzidas por Mano no período "funcionam mais como evidências taxonômicas de margem, como marcas de lugar, de onde o es-

147 Sánchez foi curador do inSite5, em 2005, de cuja edição Rubens Mano participou com a proposição visible, distribuindo bótons pela cidade com a inscrição da palavra em baixo relevo. O projeto inSite ocorreu em cinco ediçōes, todas realizadas na fronteira entre o México (Tijuana) e os Estados Unidos (San Diego). paço poderia ser experimentado como outro destino, e reapropriado a partir da pessoa". ${ }^{148}$ As fotografias falam desse mistério do espaço e da imprevisibilidade dos percursos potenciais que todo lugar detém.

$\mathrm{O}$ ato de perceber o espaço por sua reconstrução em imagem é apontado por Laymert dos Santos como uma das centralidades da obra de Mano. Segundo o crítico, ambas, arquitetura e fotografia, operam um corte de fluxo no real "não para demarcar um terreno nem para fixar um momento privilegiado, mas para descobrir, por um momento, o processo pelo qual o espaço se faz imagem e, ao fazê-lo, se constitui como espaço perceptível", ${ }^{149}$ ou seja, possível de ser percebido.

Seja nas fotografias de casa verde, bueiro e entre - onde à alteração do lugar corresponde uma intervenção concreta do artista, mesmo que efêmera ou silenciosa - ou nos registros de disponha e súbitas paisagens - em que a transformação do lugar se dá na passagem do tempo, que encarna o abandono daquele lugar pelo homem -, as obras de Rubens Mano analisadas neste primeiro conjunto se situam entre o registro e a encenação, a fotografia e a intervenção. Exatamente por se colocaram neste terreno ambíguo, suas imagens performáticas são tão intrigantes.

\section{FOTOGRAFIA, ENTRE PERCEPC̣̃̃O E EXPERIÊNCIA}

No contexto da arte contemporânea, a fotografia é apontada por Lorenzo Mammì como um medium de destaque entre os anos 1990 e 2000. Neste período, a noção clássica de enquadramento ${ }^{150}$ (consubstancial à foto) cede lugar

148 Sánchez, Osvaldo. Rubens Mano. 100 artistas latinoamericanos. Madri: Exit, 2007, s.p.

149 Santos, Laymert Garcia dos. Uma arte do espaço e de sua produção. São Paulo, 2004. (Tradução do 14 francês fornecida pelo artista. Original publicado na revista Parachute, n. 116. Montreal, out.-dez 2004) 150 "Na foto clássica [..] por um lado, ao esta no to " confere de, como se a fotografia mostrasse algo mais profundo e verdadeiro do que aquilo que a própria coisa 
à encenação - ou seja, o que seria uma apreensão mais intensa da realidade dada pelo enquadramento intencional do olhar do fotógrafo, é substituída por fotografias de situações construídas de antemão pelo artista com o propósito de serem fotografadas. ${ }^{151}$ Isso implica em dizer que, segundo Mammì "nas fotos contemporâneas, a remissão a um código ou a um repertório preexistente de imagens é declarada, enquanto nas fotos clássicas, ainda que haja referências iconográficas evidentes, a tomada imediata do fato real está sempre em primeiro plano". ${ }^{15}$

As "imagens performáticas" de Rubens Mano parecem se situar entre uma coisa e outra: nem tão reais assim que possam ser tomadas como espelhamento inercial do fato urbano, nem tão encenadas a ponto de abandonar por completo sua pregnância com o real. Nesse sentido, a potência dos trabalhos de Mano parece residir justamente nesse espaço entre, em busca de dar relevo à percepção do lugar, ou de sua reconstrução, por meio de uma experiência sensível capaz de transformar a nossa percepção de mundo, rompendo o anestesiamento do olhar e do corpo que habitam esses espaços na cidade.

Aos olhos de Mammì, é justamente em torno da noção de experiência que ele localizaria os trabalhos mais interessantes na produção contemporânea. No panorama atual, o crítico pondera que a arte contemporânea se encontra numa sinuca de bico, entre duas estratégias: a do apelo imediato à evidência, pelo fato da obras se apresentar de forma poderosa ao público, encantando-o; e a da timidez, em que não há sedução, apenas conteúdos (imagens, textos, documentos...), que perigam tornar-se um "não-acontecimento", pois requisitam do público um tempo para adquirir significado sob um fio narrativo ou um raciocínio. Entre essas duas estratégias, haveria uma saída possível, cujo valor estaria na experiência:

fotografada, em seu estado natural, estaria disposta a mostrar". Mammì, Lorenzo. As bordas. O que resta: arte e crítica de arte. São Paulo: Companhia das Letras, 2012, p. 107

151 Mammì dá como exemplo os trabalhos de Cindy Sherman e Jeff Wall, cujas fotos são feitas em estúdio e têm suas produções minuciosamente documentadas. Ibidem.

152 Ibidem, p. 108.
Não se trata aqui da experiência de reconstrução ou constituição de um mundo, mas da descoberta de resíduos, restos, afrouxamentos da malha dos significados, em que um contato mais intenso com aquilo que não é imediatamente linguagem ainda é possível. ${ }^{153}$

Mammì se refere à possibilidade de ir em busca do lugar onde uma experiência sensível - um corpo, uma realidade enfim - ainda possa ser encontrada. O que pressuporia uma consciência de que isso só se daria nas margens, nas esgarçaduras. ${ }^{154}$

É a partir da perspectiva do espaço entre (“in-between") e do valor da experiência que as três situações que envolvem as três proposições de Mano apresentadas no próximo capítulo serão abordadas.
153 Ibidem, p. 115.

54. Essa vertente é exemplificada pelo crítico a partir da obra de Francis Alys e Tacita Dean. Ibidem. p. 117. 
capítulo 3

0 espaço em ato 
No conjunto de obras tratadas no Capítulo 2 desta tese, o estudo das obras se concentrou inicialmente em proposições artísticas elaboradas por Rubens Mano que buscam "construir lugares dentro de lugares". A ativação desses lugares supunha intervenções silenciosas transpostas para a fotografia, que procuravam ativar outras percepções sobre um dado contexto, tanto por parte do artista quanto do observador (perceptor). O processo de concepção dessas obras envolveu uma relação intrínseca entre arquitetura e fotografia, espaço e imagem. A construção de uma "imagem performática" se verificou na transposição fotográfica de uma ação do artista no lugar, por meio da qual Mano dava relevo a certas condições e certas camadas não explícitas no cotidiano da cidade.

Da reconstrução imagética do lugar - operada a partir de uma genealogia urbana intrinsecamente nômade - seguir-se-á para o estudo de três situações análogas, porém distintas, em que a construção de lugares não se dá mais pela formulação imagética de uma intervenção num dado local, mas na experiência de duração da própria obra, percebida pelo observador no espaço-tempo. A essas situações correspondem as três obras de Rubens Mano detetor de ausências, calçada e vazadores, designadas aqui como "espaços em ato"; elas se defrontaram com as circunstâncias espaciais, históricas e culturais de cada lugar em que se deram - fossem estas manifestas em escala urbana (da circulação metropolitana), em escala local (de vizinhança), ou em escala "institucional" (que corresponderia ao estatuto da própria arte).

Todas as três proposições espaciais foram concebidas para contextos específicos, que envolviam espaços públicos abertos. Assim, à primeira vista, elas filiam-se a um certo tipo de arte produzida a partir do lugar em que se instala, que leva em consideração as características do contexto, e que emergira com grande intensidade nos anos 1960, naquele momento se contrapondo ao enrijecimento da autonomia da arte moderna. É desse período o surgimento da poética do site-specific work, que repôs o problema do lugar e do contexto em que a obra se dá, uma das questões fundamentais da arte contemporânea. De par com isso, as três proposições de Mano também estão impregnadas por um valor fenomenológico impresso na ativação da obra pelo observador, que 
reporta igualmente à década de 1960, quando se verificou uma mudança estrutural do papel do observador na obra, enunciada, no caso brasileiro, pelos artistas Lygia Clark e Hélio Oiticica.

Apesar das filiações, o estudo minucioso das três proposições do artista revelará que tais prerrogativas dos anos 1960 e 1970 são insuficientes para abarcar os múltiplos sentidos das intervenções elaboradas por Mano, até porque o panorama encontrado é outro. No contexto da produção contemporânea, apesar de essas filiações ajudarem a entender certos desdobramentos da arte desde os anos 1960, elas limitam uma leitura mais comprometida com a singularidade da concepção, do fazer e do contexto estruturado pela obra corroborando com as considerações tecidas por Ricardo Basbaum e Eduardo Coimbra, expostas na Introdução. Desde pelo menos meados dos anos 1980 fica difícil estabelecer categorias e/ou enquadrá-las em grupos ou movimentos (e este é, por certo, um dos desafios da pesquisa que se debruça sobre a produção contemporânea). Assim sendo, deu-se continuidade à valorização de um estudo aprofundado de cada proposição artística, considerando suas especificidades tanto espaciais quanto históricas, culturais e institucionais

As concepções de detetor de ausências, calçada e vazadores, obras realizadas respectivamente em 1994, 1999 e 2002, se deram em três situações análogas. Análogas porque envolveram trabalhos "comissionados", quer a convite da instituição quer do curador, e foram concebidas a partir do contexto em que se implantaram, urbano e/ou institucional. Análogas também porque em todos os casos o trabalho pressupôs um envolvimento direto, corporal, do observador na experiência espaço-temporal da obra - podendo ser um espaço aberto na cidade ou situado no intervalo entre um espaço aberto e um espaço fechado (institucional). Em todos eles, é como se o espaço praticado encarnasse o ato revelador de suas próprias circunstâncias existenciais.

São situações distintas porque cada proposição, a seu modo, foi mobilizada por contextos institucionais e artísticos específicos, que implicaram diferentes negociações com as esferas pública e privada, do mundo artístico e extra-artístico, numa trama social e política complexa. Além disso, elas lidaram com escalas variadas no processo de elaboração, abarcando circuns- tâncias locais, âmbitos institucionais especializados e contextos urbanos monumentais (não necessariamente nessa ordem nem excludentes entre si). E, nesse sentido, produziram resultados muito diversos, que implicaram repercussões menos ou mais acaloradas no métier da arte contemporânea.

A primeira delas, detetor de ausências, foi deflagrada pelo convite do curador Nelson Brissac Peixoto ao artista para participar da segunda edição do projeto Arte/Cidade, inaugurada em setembro de 1994. Ao longo dos anos, a obra detetor de ausências acabou se mostrando um divisor de águas na produção de Rubens Mano, por representar um transbordamento do fato fotográfico em práticas artísticas mais expandidas. Ainda que suas proposições já viessem sendo construídas a partir de questões que emergiam da problemática da arquitetura, da cidade, da produção do espaço e do lugar, a partir daqui elas se dão na duração mesma de suas ações, convocando o público, ainda que sutil e silenciosamente, a tomar parte delas. Rubens se mostrará interessado não só em elaborar questões para além do "fotográfico" - em direção à superação da distinção entre linguagens artísticas (numa certa tendência à hibridizacão dos meios decantada dos anos 1980), como também em produzir fricções entre o campo artístico e o "extra-artístico", no diálogo com outras disciplinas do conhecimento.

A perspectiva contextual que orienta a atuação de Rubens a partir dos anos 1990 pode ser situada num panorama mais amplo, não só da produção local como da internacional, cuja década repôs um interesse pelo mundo real e pela construção de lugares diante das crescentes virtualidades do contemporâneo. ${ }^{155}$ Um novo interesse pelo cotidiano é mobilizado por outros desafios, distintos daqueles dos anos 1960 e 1970; aqui, o modo de vida produzido pela modernidade "incompleta" somara-se às distorções provocadas pelas

155 O interesse de certas práticas artísticas pelo real tensionara a nova condição urbana advinda dos processos de globaizac̃o descritos por Lucrecia Ferrara nas metáforas do progresso eda modenprocessorticalide vecides

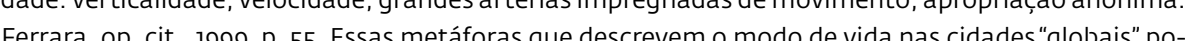
a cidades "globais" podem ser transpostas igualmente para São Paulo a partir da década de 1990. 
forças econômicas da globalização dos mercados (verificadas tanto na arte quanto nas cidades), bem como pelos processos de financeirização das trocas culturais e simbólicas dali decorrentes.

Sobre esse novo ideal de aproximação entre arte e mundo cotidiano a partir da década de 1990, o crítico de arte Lorenzo Mammì considera que:

A arte já não pode reclamar autonomia, mas tampouco pode se apegar à fusão de arte e vida que deveria pretensamente substituir a autonomia, porque a vida se tornou um conceito tão evanescente quanto a arte ou, em todo caso, deixou de dialogar com ela. ${ }^{156}$

O que restaria à arte atual?, indaga o crítico. Aos olhos de Mammì, a qualidade mais interessante da produção da arte contemporânea recente residiria na experiência enquanto obra. E é justamente a partir do tripé espaço, percepção e experiência que a obra de Mano tenderá a se desenvolver, expressa de modo exemplar nas três situações que serão aqui estudadas.

\section{ANOS 1990: AS NOVAS PRÁTICAS CONTEXTUAIS}

De par com o interesse renovado pelo mundo real e pela problemática da vida urbana, a partir da década de 1990 parte da produção artística tratou de borrar as determinações físicas que o lugar e o contexto tinham impostos à obra. Os paradigmas que orientaram uma prática do espaço assentada na vinculação direta e fisicamente inseparável da obra com o lugar ao qual se endereçava, e amplamente difundida a partir dos anos 1960 com a minimal art e a poética do site specificity, vinham sendo questionados desde meados dos anos 1980 (a exemplo da polêmica instaurada em torno da obra Tilted Arc, de Richard Serra). Surgia uma nova acepção de espaço, esgarçada pelas práticas contemporâneas, abordado não mais exclusivamente em seus aspectos físicos e fenomenológicos, mas também em suas implicações socioculturais (do espaço ao lugar antropológico, identitário, relacional e histórico). No caso de Mano, isso corresponderia a uma abordagem sob o ponto de vista da produção social do espaço, que passa a considerar com mais intensidade não só o papel do artista na fruição da obra, mas a atuação do(s) sujeito(s) social(is) na cidade.

Em seu artigo "Espacialidade e arte pública", publicado em 2001, o historiador da arte espanhol Jesús Carrillo aponta que a partir dos anos 1990 o espaço físico apriorístico passa a ser entendido como uma construção social, fruto da interação entre seus agentes:

A proliferação do pensamento metafórico-espacial típico do pós-modernismo subtraiu a especificidade da noção tradicional de espaço, deixando de identificar este com a categoria abstrata e universal que molda o pensamento ou com a entidade física concreta sobre a qual nossos pés se apoiam e sobre a qual se realizam nossas ações. O espaço converteu-se em um tabuleiro de operações construído ou projetado discursivamente a partir das estratégias de poder, um poder ou poderes que são implantados principalmente por meio da territorialização e da distribuição e redistribuição contínuas de posições espaciais: den- 
tro fora, centro margem, contiguidade fraturada, fronteira nacional etc. Nesse sentido, o espaço deixaria de ser um a priori para ser uma construção, um produto gerado a partir da ação, da interação e da competição entre os diferentes agentes. ${ }^{157}$

A intencionalidade artística de revelar certos aspectos de lugares que se apresentam numa condição eminentemente urbana, a partir de suas gêneses socioculturais (de seus códigos, usos e relações de poder), é apontada por Lucy Lippard como uma das vocações potentes da chamada "arte pública" produzida nos anos 1990. "Eu definiria arte pública como um trabalho aces sível de qualquer tipo que se preocupa, desafia, envolve e consulta o público para ou com quem é feito, respeitando a comunidade e o meio ambiente". ${ }^{158}$ Suas raízes não deixam de remontar ao ambiente experimental das décadas de 1960 e 1970, em que a produção (social) do espaço emergia como fato crucial - identificado por Henri Lefèbvre na emergência da "problemática urbana” ${ }^{159}$-, que era preciso o artista enfrentar.

157 "La proliferación del pensamiento metafóricoespacial típico del postmodernismo ha restado especificidad a la noción tradicional de espacio, dejando de identificarse éste con la categoría abstracta y universal que enmarca el pensamiento o con la entidad física concreta sobre la que se apoyan nuestros pies y se realizan nuestras acciones. El espacio ha pasado a convertirse en el tablero de operaciones construido o proyectado discursivamente desde las estrategias del poder, un poder o poderes que se despliegan primordialmente mediante la territorialización y la continua distribución y redistribución de posiciones espaciales: dentro fuera, centro margen, contigüidad fractura, patria frontera, etc. En este sentido, el espacio pasaría de ser un a priori a ser una construcción, un producto generado a partir de la acción, interacción y competición entre los distintos agentes". Carrillo, op. cit., p. 110. 158 "I would define public art as accessible work of any kind that cares about, challenges, involves, and consults the audience for or with whom it is made, respecting community and environment". Lippard, op. cit., 1995, p. 121.

159 Lembrando que cada modo de produção gera o seu espaço próprio. E, segundo Lefèbvre na transição entre os anos 1960 e 1970 , a produção de mercadorias clássicas deu lugar à produção do espaço e realidade industria passoù a realidade urbana A produção social do espaço englobaria portaço, a realicade industria passou á forma concreta, como se fosse uma projeção das relações sociais. Ele seria a interma ga

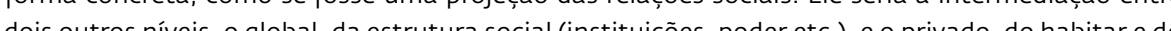
indivíduo Cf Lefèbure, op cit. 1969 .
Tal como em Carrillo, para Lippard a tomada de consciência de certas práticas artísticas que se debruçam sobre o problema do lugar deveria ser capaz de perceber outras camadas implicadas no espaço urbano para além de sua dimensão física, incluindo, segundo a crítica, uma extensa investigação visual e verbal que incorporasse a interdisciplinaridade e os estudos multiculturais. Essas linhas de investigação e produção estariam mais ligadas a "contextos e conteúdos, do que a estilos e correntes", 160 o que reforça a hipótese apresentada na Introdução de que uma aproximação à obra de arte contemporânea requer cada vez mais uma leitura contextual e imersiva para "desvendá-la" sem generalizações.

As análises sobre a produção de arte do período interessada no debate acerca da cidade encontraram ressonância nos escritos da curadora norte-americana Nina Felshin. De acordo com a autora,

a "nova arte pública" centrou-se na identificação do conceito de comunidade ou do público como lugar e a caracterização do artista público como aquele cujo trabalho é essencialmente sensível aos problemas, necessidades e interesses que definem essa entidade indescritível e difícil de definir que é esse lugar. De acordo com essa definição, a arte pública seria qualquer arte dotada de um certo compromisso político, o que pressupõe uma localização pública e uma recepção participativa. ${ }^{161}$

Apesar de concordar em parte com as definições de Lippard e Nelshin, o que

160 Lippard, op. cit., 1995, p. 120.

167 'El debate sobre el 'nuevo arte público' se ha centrado en torno a la identificación del concepto de comunidad o de público como lugar [sítel y la caracterización del artista público como aquel cuyo trabajo es esquiva y difícil de definir que es ese lugar. Según esta definición, arte público sef́a to esa entidad esquiva y dific de de fin que es ese lugar. Según esta defnición, ante público seńa todo aquel arte dotado de un cierto compromiso poltico al que se lep resupone una localización pública yuna recep(orgs.), op. cit., p. 85 . 
interessa aqui é menos tentar enquadrar a produção de Rubens Mano numa nova categoria da "arte pública" fundada pelo campo da crítica em meados dos anos 1990, e mais situar suas obras abordadas neste segundo conjunto de análise dentro de uma prática contextual, pela qual a visada interdisciplina em relação ao lugar é o motor principal para se construir uma percepção crítica sobre a produção do espaço na cidade. Ela pressupõe (mesmo que indiretamente) um compromisso político do artista e uma disponibilidade ética e estética do público em se engajar no debate da arte contemporânea e da vida urbana, por extensão.

\section{O CASO ARTE/CIDADE EM SÃO PAULO}

A matriz contextual reivindicada por parte dos artistas a partir da década de 1990 na cena internacional aparece igualmente no horizonte brasileiro, especialmente nas grandes cidades. No caso de São Paulo, os artistas interessados em lidar com os novos desafios da arte numa perspectiva contextual buscaram outros lugares para a realização da obra, em diferentes contextos físicos, sociais e culturais, mobilizados por um mundo urbano extra-artístico.

O exemplo paradigmático que percebeu as mudanças ocorridas no território paulistano no período como uma questão local premente foi o projeto Arte/ Cidade, idealizado por Nelson Brissac Peixoto, que rendeu várias edições, as quais voltaram-se a diferentes situações urbanas paulistanas em transformação. Elas ocorreram em quatro momentos: a primeira delas foi realizada no edifício histórico do antigo Matadouro Municipal da Vila Mariana, em 1994; a segunda edição, ainda no mesmo ano, se deu na região central da cidade, em torno do Viaduto do Chá, onde a situação não tinha limites precisos e se colocava mais em termos de fluxo e deslocamento; a terceira edição, realizada em 1997, ocorreu numa antiga região fabril, ao longo da linha férrea, entre a Estação da Luz e as Indústrias Matarazzo; e a última delas, em 2002, no eixo da Zona Leste, região ligada ao primeiro ciclo de industrialização da cidade, cuja ocupação mais recente deixou vastos intervalos no território.

De modo geral, o projeto curatorial de Brissac instaurou uma nova visibilidade da arte contemporânea na capital paulista, não mais restrita aos limites institucionais de um museu, uma galeria ou qualquer outro recinto sacralizado da arte. O curador partiu da ideia de que "constituídas no contexto de instituições, as obras correm o risco de serem lidas como signos dessas instituições. Daí a busca de sítios abandonados ou sem uso cultural [a priori] como alternativa". ${ }^{162}$

62 Peixoto, Nelson Brissac. Arte \& Cidade. Ferreira (org.), op. cit., p. 492. (O texto foi publicado originalmente no livro Arte pública, editado pelo Sesc, em 1998.) 
Uma vez fora dos contornos institucionais da arte, Brissac também se preocupou em diferenciar sua proposta do formato de um evento: ao lançar um projeto de "intervenções", cujo caráter é necessariamente comprometido com o lugar de sua realização, buscou uma direção contrária à natureza de um evento cultural, que geralmente denota um tipo de espetáculo que ignora o lugar. "A intervenção artística é uma leitura do lugar", ${ }^{163}$ defende Brissac.

A primeira edição do Arte/Cidade aconteceu no antigo Matadouro Munici pal da Vila Mariana, em março de 1994, e teve como subtítulo "Cidade sem janelas”. O partis pris curatorial colocava o edifício histórico desativado como uma provocação contextual diante dos artistas convidados: uma construção obsoleta, cercada por muros, cuja intransponibilidade escondia a história dos usos que se fez dela ao longo do século XX, restando apenas uma memória em ruína. Diante de um espaço murado, com arquitetura pesada e isolada do resto da cidade, os artistas se defrontaram com a inércia da matéria, a sedimentação do tempo e os resquícios de história daquele lugar.

Segundo Agnaldo Farias, que colaborou com Brissac na concepção curatorial do projeto, o tema "Cidade sem janelas" foi lançado como uma espécie de emblema para que os participantes pudessem ter clareza de qual era o solo conceitual comum em que todos estariam se movendo. Além disso, os curadores ofereceram uma lista de palavras que abarcava o universo a que se dispunham tratar: "prédios, empenas, fachadas, becos, vielas, skyline, impotência, solidão, clausura, angústia, opacidade, saturação, acúmulo, artérias, detritos, ruínas, sobras, escombros, concreto, lama, pedra, metal, solo mineral, arqueológico, porosidade, espessura, massa, peso, gravidade, cheio, fechado, duro, cinza, amorfo, inerte, descascado, sujo, usado, volume, sobreposição, entrelaçamento, articulação, ruído, indistinção, amontoado, aglomerado, acoplamento, engate, expansão, superfície, plano, epiderme, aridez, secura". ${ }^{164}$

163 Peixoto, Nelson Brissac. Intervenciones urbanas, Poliester [Arquitetura], vol. 5, n. 15, primavera 1996, p. 21.

Darias. Agnaldo. Arte/Cidade. Disponivel em: <http://www.artecidade.org.br/novo/acl/20.htmmCidade>. Acesso em 6 dez. 2017.
Durante três meses, os curadores se reuniram com os participantes para discutir os projetos. O espectro diversificado do grupo, entre artistas, arquitetos, cineastas, fotógrafos e coreógrafos, ${ }^{165}$ colaborou para a construção de uma abordagem interdisciplinar daquele contexto. Boa parte deles lidou com a asfixia das antigas construções do conjunto, a densa materialidade das edificações abandonadas e o aspecto residual dos usos que se fez daquele lugar. Exemplo disso são as obras de Carmela Cross e Marco Ciannotti, que escolheram os recintos enclausurados do abate para suas intervenções arqueológicas e cromáticas, respectivamente; a obra de Éder Santos, um vídeo que registra o deslocamento acelerado de uma viagem de trem projetado diretamente sobre a terra; e a de José Resende, uma espécie de teatralização da sedimentação da matéria no tempo, onde um guindaste reorganiza ininterruptamente uma pilha de blocos rochosos encontrados no local.

Na segunda edição, realizada em setembro do mesmo ano, a curadoria optou por trabalhar numa situação urbana de fluxo, onde os limites não eram definidos nem por paredes, nem por um lote. Intitulada "A cidade e seus fluxos", o perímetro de atuação considerado na proposta de Brissac partia do entorno do Viaduto do Chá e se estendia pelo Vale do Anhangabaú; seus contornos eram pontuados por três construções - o prédio da Light, a antiga sede do Banco do Brasil e o edifício Guanabara, cujas distâncias somavam alguns quilômetros. Era preciso, portanto, se deslocar entre eles para apreciar os trabalhos e vivenciar a metrópole.

Inaugurava-se aí uma nova vocação para o Arte/Cidade em relação à primeira edição: aproximar o cotidiano da cidade da experiência estética da arte contemporânea e vice-versa. Nessa nova proposta curatorial, os artistas deveriam captar a atenção do cidadão, retirá-lo de sua passividade em trânsito na cidade e deslocar seu olhar para a obra e, por decorrência, para a cidade.

165 Integraram a exposição: André Klotzel, Anne Marie Sumner, Antonio Saggese, Arnaldo Antunes, Arthur Omar, Carlos Fajardo, Carmela Gross, Cassio Vasconcellos, Éder Santos, Enrique Diaz, Jorge Furtado, José Resende, Livio Tragtenberg, Marco Giannotti e Susana Yamauchi. 
Participaram da segunda edição 22 convidados, entre artistas e arquitetos. ${ }^{166}$ Porém, a maioria deles optou por realizar o trabalho em um dos três edifícios históricos, a exemplo das instalações de Regina Silveira e Waltercio Caldas (no antigo edifício da Light) e Iole de Freitas e Tadeu Jungle (na ex-sede do Banco do Brasil). Dos poucos que se abriram ao enfrentamento da cidade, no espaço público aberto, destacam-se os artistas Cuto Lacaz e Rubens Mano.

Para as obras que ocupariam os recintos fechados, a curadoria reservou o último andar de cada um dos edifícios. Com isso, evitava-se criar uma ideia institucional de ocupação dos prédios, ao mesmo tempo que se promovia um percurso fragmentado, à semelhança da experiência de se deslocar pelo centro de uma grande metrópole contemporânea. Três anos mais tarde, em artigo publicado na revista Lapiz, Brissac expõe as razões conceituais da fragmentação do percurso:

Hoje, toda experiência urbana implica ruptura, distância, intervalos que são produzidos no interior da própria cidade. [...] A fragmentação do tecido urbano parece criar descontinuidades intransponíveis, uma distância absoluta entre os lugares. Uma situação que, devido a sua escala, não se oferece de imediato à nossa percepção. ${ }^{167}$

Em 1997, a terceira edição se desloca do epicentro da formação da metrópole em direção à zona oeste, numa antiga zona fabril da cidade, ao longo da linha férrea. A região escolhida se caracterizava por áreas decadentes e edificações abandonadas, inacessíveis ao olhar e desconectadas da organização urbana da metrópole, cujas cicatrizes foram originalmente marcadas pela linha férrea que separara o território em duas margens.

166 Abílio Guerra e Marco Valle, Andrea Tonasci, Anna Muylaert, Arthur Lescher, Arthur Matuck, Carlos Fadon, Carlos Reichenbach, Fujocka, Guto Lacaz, Iole de Freitas, José Wagner Garcia, Lenora de Barros, Otavio Donasci, Regina Silveira, Rubens Mano, Tadeu Jungle, Tadeu Knudsen, Walter Silveira, Barros, Otavio Donasci, Regina Silv
Waltercio Caldas eWilson Sukorski.

167 Peixoto, Nelson Brissac. El impacto de la metrópolis en la creación contemporánea, Lapiz, n. 134135, jul.-set. 1997, p. 80
Arte/Cidade 3: a cidade e suas histórias também previa o deslocamento do público ao longo de vários pontos espalhados pela região; porém, o percurso não era definido "aleatoriamente", tal como na edição anterior do Anhangabaú, mas seguia o trajeto do trem, desde a Estação da Luz, passando pelos silos do antigo Moinho Central, na Barra Funda, até chegar aos galpões e chaminés que restavam das antigas Indústrias Matarazzo, no bairro da Água Branca.

Segundo o texto de apresentação do Arte/Cidade 3:

As obras concebidas pelos artistas para o evento passaram a ser cada vez menos relacionadas com sua própria produção regular (concebida e realizada em estúdio), para refletirem cada vez mais a relação com a situação e os locais. Um aprendizado foi sendo feito aí, um procedimento foi sendo configurado. As obras tendem a levar mais em consideração o sítio, a inserção arquitetônica, a escala urbana, a complexidade das situações (abundância de informações, coexistência com outras intervenções e atividades). ${ }^{168}$

Nessa perspectiva, dentre os trabalhos mais contundentes apresentados na edição de $1997^{169}$ estão as intervenções de Laura Vinci (fig. 16) e Nelson Felix, ambas no prédio do Moinho. Vinci criou um dispositivo que aludia à dissolução da estrutura em concreto daquele edifício e rompia com a sua horizontalidade: a ampulheta montada no recinto vazava areia de um andar para o outro por meio de um orifício no piso; o dispositivo armado pela artista alternava

168 Texto de apresentação do Arte/Cidade 3. Disponível em: <http://www.artecidade.org.br/site97_99/ ac3/apres.html >. Acesso em 5 dez. 2017.

169 No ano de 1997, o projeto contou com a participação de: Carlito Carvalhosa, Carlos Vergara, Cildo Meireles, Dudi Maia Rosa, Eliane Prolik, Evandro Carlos Jardim, Flavia Ribeiro, Fernanda Gomes, Geórgia Kyriakakis, Helio Melo, José Spaniol, Laura Vinci, Nelson Felix, Paulo Pasta, Ricardo Ribenboim, Rodrigo Andrade; Arnaldo Pappalardo, Cao Guimarães, Marcos Ribeiro, Patrícia Azevedo, Rochelle Costi, Willi Biondani, Carlos Nader, Joel Pizzini, Lucas Bambozzi, Roberto Moreira e Marcelo Dantas, José Miguel Wisnik, Ciro Pirondi, Fernando de Melo Franco/Milton Braga, Paulo Mendes da Rocha, Regina Meyer//ê Americo/Luiz Junkeira e Ruy Ohtake. 

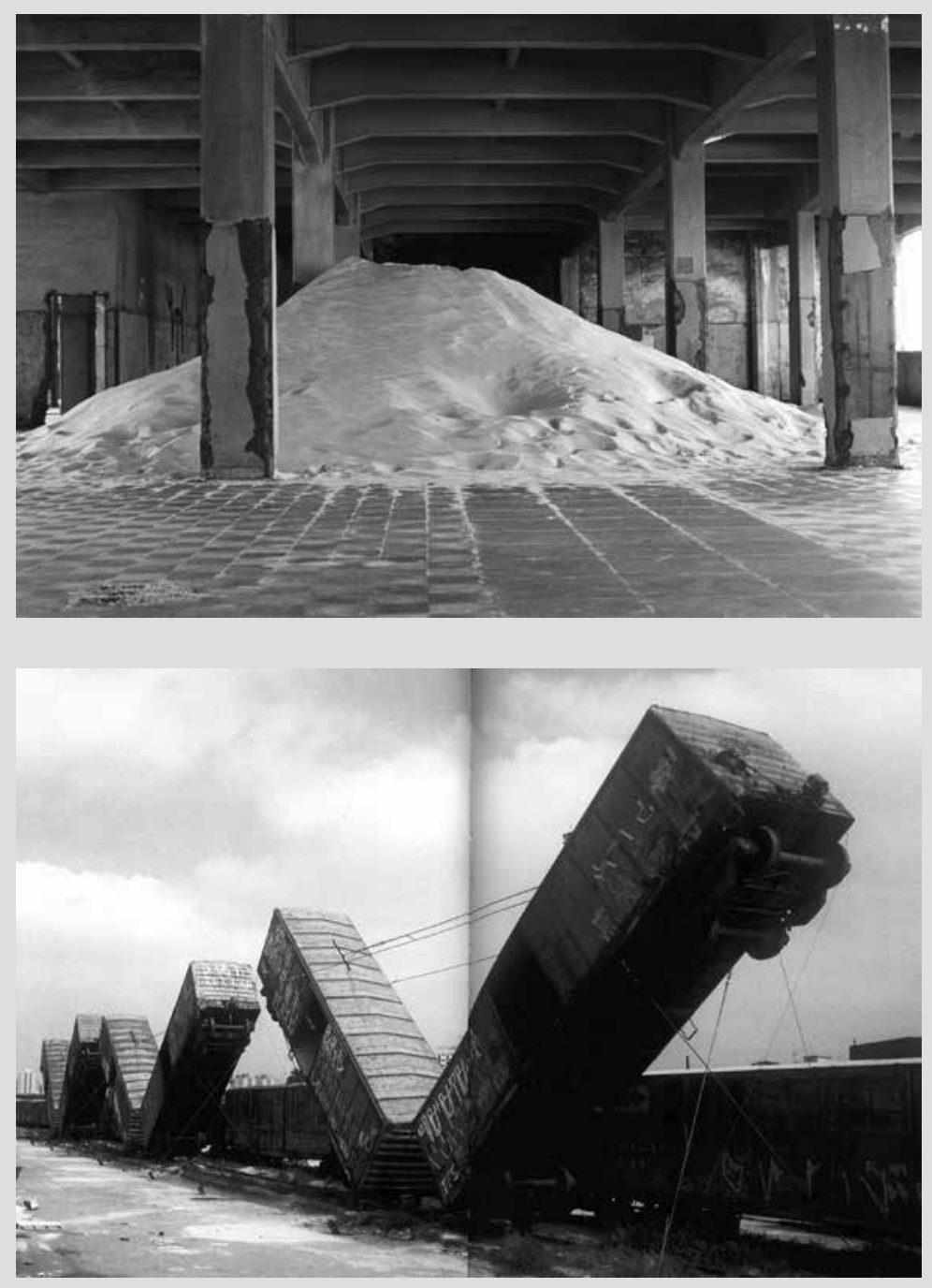

a formação do acúmulo de matéria nos dois andares num ciclo contínuo. A passagem do tempo aludia às ruínas do conjunto fabril dos primórdios do crescimento da cidade, mas ao mesmo tempo resistia ao seu completo desaparecimento, tentando se reerguer sucessivamente.

Tanto quanto Vinci, a intervenção de Felix incidiu diretamente sobre a estrutura do edifício. Ao recortar um trecho do piso de um dos andares, de $1,5 \times 10$ metros, o artista abre uma nova perspectiva no espaço que escancara os elementos estruturais da arquitetura. Esses pedaços de laje foram pendurados por cabos de aço a poucos centímetros do piso inferior, modificando o sentido gravitacional do nível zero do chão, alternando a nossa percepção sobre a relação corpo-espaço.

A quarta edição do projeto de Brissac, realizada em 2002, ocupou os vestígios de um bairro industrializado há muito abandonado pelas empresas e pelo poder público, numa área de cerca de 10 quilômetros quadrados na região leste de São Paulo. A zona leste foi palco da imigração e da primeira industrialização da cidade nos anos 1920 (a exemplo dos bairros do Belém, Mooca, Pari e Brás), e atravessou um longo período de desinvestimento a partir da segunda metade do século XX. Segundo o texto de apresentação dessa edição, nas últimas décadas projetos de enclaves corporativos e habitacionais "modernizantes" produziram uma sobra de vastos intervalos no território, onde proliferaram "modos informais de ocupação do espaço urbano". ${ }^{170}$

De modo geral, os vazios urbanos são produzidos pela obsolescência das construções ao longo dos anos, em boa medida fruto das mudanças nos modos de produção (restruturação econômica) que orientam a ocupação do território urbano e que implicaram o desinteresse de áreas centrais pelas elites e pelo poder público, em detrimento de novas regiões na cidade, ainda não "exploradas" financeiramente. Essas mudanças produziram, portanto, um novo espaço pautado pelas distorções, muitas vezes intencionais, do merca-

FIG. 16 Laura Vinci. Sem título, 1997 Instalação com pó de mármore. Vista na exposição do Arte/Cidade3: a cidade e suas histórias
FIG. 17 José Resende. Sem título, 2002 Obra efêmera com vagões de trem e cabo de aço, implantada no Pátio do Pari, São Paulo. Vista da instalação no Artecidadezonaleste
70 Texto de introdução sobre o Arte/cidade - grupo de intervencão urbana. Disponível em: <http://www. artecidade.org.br/indexp.htm>. Acesso em 6 dez. 2017. 
do imobiliário. No caso da ZL, tal processo foi acentuado pela implantação de grandes sistemas de transporte que atravessaram a região para conectá-la na malha viária do centro expandido.

Esses aspectos se impuseram fortemente à atuação dos artistas convidados a participar da quarta edição do projeto de Brissac, batizada de Artecidadezonaleste, ${ }^{17}$ sediada pela unidade do Sesc no bairro do Belenzinho. Um dos trabalhos mais marcantes dessa edição foi a proposição de José Resende para o Pátio do Pari, ${ }^{172}$ na qual o artista dispôs uma sequência de vagões de trem içados ao longo da linha férrea. A obra coloca, sobretudo, o problema da reutilização dos terrenos lindeiros à ferrovia e o seu potencial para investimentos intensivos na nova reestruturação da cidade. A resposta de Resende para lidar com a situação de decadência da região é operada por meio de uma construção irônica, de um lado - a partir do jogo inusitado de vagões em posições "não-funcionais", que remetem ao encadeamento de peças de dominó ou mesmo cartas de baralho -, e por sua condição instável, de outro - onde sua obliquidade brinca com a própria ideia de escultura e arquitetura (tradicionalmente uma força vertical), desenhando o movimento no ar (fig. 17).

\section{CONTEXTO PAULISTANO, “LOCAL” E “GLOBAL”}

O contexto paulistano no qual o projeto Arte/Cidade foi implantado estava diretamente ligado aos processos de reconversão urbana da cidade-de um lado, com regiões de ocupação antiga degradadas, e, de outro, com novas áreas

171 A quarta edição reuniu artistas, arquitetos e urbanistas, incluindo brasileiros e estrangeiros. No Sesc Belenzinho, expuseram: Ana Tavares, Ary Perez, Avery Preesman, Carlos Fajardo, Carmela Gross, Cássio Vasconcelos, Hannes Foster, Hermann Pitz, Nelson Felix, Regina Silveira e Waltercio Caldas. As intervencões na cidade ficaram a cargo de: Angelo Venosa, Antoni Muntadas, Ateliêvan Lieshout, Carlos Verera Casa Blindada Dennis Addams, José Resende, José Wagner Garcia Marco Ciannotti, Mauríco Dias e Walter Riedweg, Paul Meurs, Rem Koolhaas, Ton Matton, Vito Acconci e KrzyszztofWodiczko. 172 O pátio foi inaugurado pela São Paulo Railway em 1891, e servia como estacionamento de vagões, depósito de mercadorias e ponto de carga e descarga. valorizadas pelo mercado imobiliário que se conectavam com o mundo global. No artigo "Arte pública, cidade privada", os autores Elisabetta Andreoli e Laymert dos Santos ilustram essa dupla condição da capital paulista em meados da década de 1990:

O binômio arte/cidade já vem sendo usado há algum tempo como uma maneira de valorizar a cidade, se não substancialmente, ao menos em termos de imagem, marketing, sobretudo numa época de globalização, quando as identidades nacionais parecem dar lugar a outras, mais locais. Além disso, em São Paulo, como em toda parte, os debates atuais sobre "pós-modernismo" e "globalização" acarretaram um interesse maior pelo tema da cidade, particularmente da metrópole e de suas transformações..$^{173}$

Os autores também lembram que o Arte/Cidade ocorreu "num momento em que várias iniciativas afirmavam a urgência de tratar dos problemas da cidade, e em particular do centro histórico de São Paulo". ${ }^{174}$ Na verdade, a região vinha sofrendo um processo de abandono por parte das grandes instituições financeiras e comerciais desde pelo menos a década de 1970, em favor da valorização de outras áreas, tais como os centros empresarias e financeiros instalados na Paulista, Faria Lima e Berrini, respectivamente. Segundo Andreoli e Santos, o processo de "degenerescência urbana" pelo qual a cidade passara nas últimas décadas resultou na perda do papel econômico e simbólico do centro, no declínio do espaço público e na degradação da infraestrutura da cidade, dentre outros fenômenos. Na capital paulista, a situação se agravava ainda mais sob o ponto de vista do pedestre:

173 Andreoli e Santos, op. cit., p. 285

174 Ibidem. 
São Paulo quase deixou de ser um lugar para passeio em virtude da fragmentação urbana, de razões de segurança e das distâncias geográficas e sociais. [...] As pessoas comuns tendem a evitar a cidade, atravessando-a somente quando necessário, enquanto os privilegiados se isolam atrás dos vidros fechados dos carros e dos muros dos enclaves residenciais e comerciais. Aqui, a cidade é experienciada como um inimigo ou, na melhor das hipóteses, como um obstáculo. ${ }^{175}$

Ao considerar os processos intrínsecos a São Paulo, percebe-se que a descontinuidade produzida pela dispersão das atividades no território e pelos interesses imobiliários foi ainda mais acirrada com o advento da mundialização das cidades, e resultou no que os urbanistas chamam de "cidade cindida" - ou o que Otília Arantes apontara como uma cidade pautada por duas velocidades -, onde à infraestrutura da malha moderna em solo urbano sobrepõe-se a condição contemporânea fragmentada da cidade global, cada vez mais pautada pela desterritorialização e pela deslocalização. ${ }^{176}$

Esses fenômenos urbanos contemporâneos se explicam pelo desenvolvimento tecnológico e pelas trocas econômicas cada vez mais virtualizadas (sociedade em rede). Os novos parâmetros de ocupação do solo nas cidades globais (a produção social do espaço) foram guiados pela implantação de centros de comando da economia global/informacional (decantada dos avanços

\section{Ibidem, p. 286.}

176 A partir das análises do geógrafo italiano Giuseppe Dematteis, a urbanista Marta Lagreca ajuda a entender os aspectos da condição contemporânea - difusa e fragmentada - em relação àquela da cidade moderna: "Os novos sistemas relacionais globais e descontínuos da cidade contemporânea têm conexão com o desenvolvimento tecnológico e com as mais recentes tendências de divisão do espaço de trabalho. Segundo G. Dematteis (1989). o desenvolvimento tecnológico permite o'transbordamento dos limites' - diminuíram certos limites da economia de escala (automação), bem como se reduziu o atrito pela distância na circulação de informaçẽes (telemática). Portanto consequencia do processos e dinâmicas regidos pelas transformações nas lógicas produtivas e nas in

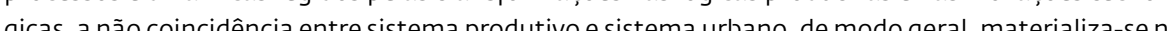
dispersão framentačão dos proessos de ocupação do território constitui um dos aspectos-chave da diferenç̧a que a cidade contemporânea apresenta em relação à moderna". Sales, op. cit., p. 47. tecnológicos), que gerenciam as atividades interligadas das redes de empresas; ${ }^{177}$ esses centros ocuparam parcelas da cidade e instituíram bolhas desconectadas do tecido urbano, caracterizadas por uma arquitetura verticalizada, lisa e espelhada, homóloga a qualquer outro centro de comando da rede global.

Esses aspectos da contemporaneidade também foram ironicamente enunciados pelo arquiteto holandês Rem Koolhaas em seu artigo "Bigness", publicado originalmente na revista Domus, em outubro de 1994:

Através da aleatorização da circulação, dos curtos-circuitos da distância, da artificialização dos interiores, da redução da massa, do estiramento das dimensões e da aceleração da construção, o elevador a eletricidade, o ar-condicionado, o aço e, por fim, as novas infraestruturas formaram uma agregação de mutações que induziram outras espécies de arquitetura. Os efeitos combinados destas invenções foram estruturas mais altas e mais profundas - Maiores - do que até aí tinham sido concebidas, com um potencial paralelo para a reorganização do mundo social..$^{178}$

Do ponto de vista da arquitetura, na interpretação de Koolhaas, o elevador com o seu potencial para estabelecer ligações mecânicas em vez de arquitetônicas - anulou e esvaziou o repertório clássico, e questões como composição, escala, proporção e pormenor tornaram-se irrelevantes. O emprego indiscriminado do ar-condicionado no interior desses volumes verticais vitrificados criava um microclima artificial que independe do lugar, é estável e se repete por toda parte do globo. O invólucro de vidro "libertara", assim, uma necessidade de correspondência entre fachada e interior do edifício, apregoada pelos modernos; seu tratamento espelhado devolve a realidade como hiperreali-

777 Castells, op. cit. p. 405

178 Koolhaas, op. cit., pp. 15-16. 
dade e faz as construções desaparecerem na paisagem da cidade. Como diz o arquiteto, "o seu impacto [da Crandeza] é independente de sua qualidade", ${ }^{179}$ "ela é impessoal" ${ }^{180}$ e se rendeu às tecnologias.

A imagem projetada de Koolhaas corresponde à paisagem da cidade global desenhada por Andreoli e Santos, a qual, segundo os autores, acarretava sensação de deslocalização (os centros empresariais têm a mesma aparência em qualquer que seja a cidade global). Em São Paulo, portanto, as mudanças tecnológicas que reestruturaram o território nas cidades globais foram em boa parte responsáveis por produzir duas velocidades na mesma "cidade": uma, engendrada na cidade "real"; e outra, vivenciada como virtualidade. ${ }^{81}$

A partir de meados de 1990, o novo foco sobre o problema do lugar na arte contemporânea, expresso na concepção do projeto Arte/Cidade, não deixa de ser um reflexo dessa cisão, na medida em que procura restabelecer uma relação mais direta e "real" com a cidade e os modos de vida que se imprimem nela.

\section{O DEBATE DA CRÍTICA}

Numa perspectiva renovada dos lugares da arte, sob um diálogo destemido com a cidade, a curadora e crítica de arte Lisette Lagnado atribuiu ao projeto de Nelson Brissac a sua devida contribuição para o debate artístico do período. Segundo ela:

179 Ibidem, p. 17.

181 O tema da cidade cindida e da sua crescente virtualidade é problematizado em diversos trabalhos de artistas brasileiros produzidos a partir de 2000 , desde a utilização de câmeras de vigilância a voos

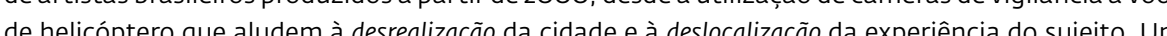
desses exemplos também surge na produção de Mano, com a obra contemplação suspensa, um video demses ex lo também su ue na pro de helicópteros do mundo, perdendo apenas para Nova York ).
A produção do evento Arte/Cidade trouxe todas as gradações teóricas que pontuam o debate sobre a pós-modernidade: a ruptura da obra com o mercado de consumo e sua consequente inserção no espaço urbano, a questão do deslocamento do público, novas tecnologias e interdisciplinaridade, a desmaterialização da arte e a construção de

“objetos específicos". ${ }^{182}$

Não se tratava, assim, de uma simples exposição de obras de arte, mas de um projeto interdisciplinar audacioso, que envolveu diferentes profissionais em constantes conversas com os artistas convidados, no intuito de promover discussões e reflexões sobre a cidade, cujos resultados seriam apresentados ao público por meio de intervenções artísticas.

Ao abrir-se às contingências da cidade, no momento em que São Paulo vivia um novo ciclo de destruição e reconstrução operado pelo mercado imobiliário e pelos novos modelos de parceria público-privado, o Arte/Cidade buscou no tecido urbano, em suas diferentes dinâmicas e configurações sócio-espaciais e históricas, o impulso mobilizador da produção artística.

Lidar com as contingências de uma grande metrópole aportava à arte contemporânea um novo sentido ampliado que tensionava os limites do fazer e da produção artística. Intervenções urbanas como as do Arte/Cidade não se resumiam à ocorrência da arte "na rua", tomando o espaço público exclusivamente como suporte. De acordo com o curador, o que estava em jogo era

o fato de que ela envolve um espectro maior de situações. E enfrentá-las exige maior riqueza de aportes, um diálogo mais amplo, lidar com um número maior de tensões do que no trabalho em locais, institucionais ou não, já destinados a uma atividade artística. ${ }^{183}$

182 Lagnado, Lisette. Arte/Cidade: a cidade e seus fluxos, Trans, vol. 1, n. 1, primavera 1995, p. 118 183 Peixoto, op. cit., 2006, pp. 487-488. 
O próprio conceito de espaço público, segundo Brissac, estava em crise, uma vez que "numa cidade onde não se sabe mais o que é público, o que é privado fomos alienados do espaço público que, na verdade, é um espaço de guerra". ${ }^{184}$ Para ele, portanto, a arte do tipo "intervencionista" poderia ajudar a nos relacionarmos com essa situação-limite da cidade contemporânea, ao contribuir "para redefinir o espaço urbano e criar novas tramas com a arquitetura, o urbanismo e as situações sociais ao redor". ${ }^{18}$

Do ponto de vista do filósofo Laymert dos Santos:

O propósito de interferir artisticamente no espaço urbano sugere a existência de uma crise intensa que afeta o homem contemporâneo e seu habitat. A Arte na Cidade é ao mesmo tempo a designação dessa crise e a elaboração de uma resposta possível para a sua percepção e entendimento. ${ }^{186}$

O projeto de intervenções urbanas também repunha o problema do lugar da arte na cidade ao reintegrar, segundo Lagnado, de forma contemporânea "a expressão estética da cidade com seu manifesto político - uma antítese fundamental para demovê-la da velha ideia de ocupação pública através de monumentos" ${ }^{187} \mathrm{O}$ ponto de vista da crítica não deixa de coincidir com a perspectiva do curador sobre a natureza de uma intervenção artística, que substitui a ideia de "monumentum erguido pela cultura institucionalizada" por um acontecimento, um “momentum da criação artística”. ${ }^{188}$

184 Ibidem, p. 489.$$
\begin{aligned}
& 184 \text { Ibidem, p. } 48 \text { I } 185 \text { Ibidem. }
\end{aligned}
$$

186 Santos, Laymert Garcia dos. A arte na cidade: entre a deslocalização e o deslocamento. Peixoto, Nelson Brissac (cur.). Arte/Cidade: a cidade e seus fluxos (Catálogo de exposiçăa). São Paulo: Marca d'Água/Secretaria de Cultura do Estado de São Paulo, 1994, s.p.

187 Lagnado, op. cit., p. 119.

188 Peixoto, op. cit., 2006, p. 492.
Essa reintegração estética da cidade passaria também pela provocação curatorial do projeto em fazer com que São Paulo visse a si própria, como aponta Lorenzo Mammì em texto crítico escrito na ocasião.

À diferença de Rio e Salvador (para não falar das metrópoles europeias ou norte-americanas), São Paulo é uma cidade cega, que não vê a si mesma. O grande mérito do Arte/Cidade é remexer nessa cegueira, cutucar a amnesia coletiva, não tanto de um ponto de vista do documentário, mas no plano do imaginário. ${ }^{189}$

Portanto, o projeto de Brissac carrega em si dois aspectos caros aos anos 1990: provocar nossa percepção para situações que não se revelam mais apenas à apreensão visual in loco, ao considerar os processos de reestruturação metropolitana e global das cidades; e ao mesmo tempo contrapor-se à apropriação institucional e corporativa dos espaços urbanos e das práticas artísticas.

Apesar de Arte/Cidade ter reunido artistas de peso, uma parte da crítica considera que as ambiçoes do projeto de Brissac tenham fracassado no sentido de provocar esses artistas a se deslocar de seus cômodos lugares de produção, comumente praticados no isolamento em seus ateliês, e enfrentar a cidade em suas dinâmicas e transformações que implicam uma nova condição contemporânea da vida urbana. Os posicionamentos de Lorenzo Mammì e Alberto Tassinari, por exemplo, consideraram que a maioria dos trabalhos parecia por demais ilustrativa de uma situação urbana, reduzindo-se por vezes uma apropriação kitsch do contexto e um comentário banal sobre ele.

Seria a arte capaz de se fazer no tempo e no espaço da cidade sem que pareça uma ilustração de suas condições de vida ou mesmo caia num decorativismo gratuito? Será que a obra se enfraquece ao restringir-se ao espaço expositivo legitimado? O desafio de Brissac se colocava, muitas vezes, no sentido de refundar uma relação mais "verdadeira" e pregnante entre a arte

189 Mammì, op. cit., 2006, p. 481 . 
e a cidade. Como intervir nessa escala imensa que impede toda e qualquer localização?, se pergunta o curador.

Para aqueles artistas contemporâneos que vivem em megalópoles nas quais as arritmias da produção industrial e dos sistemas de comunicação são mais alarmantes, trata-se de tirar partido destas contradições, atuando sobre as diferenças, os intervalos e as desproporções do sistema. ${ }^{190}$

Além da crítica aos trabalhos em si, surgiram alguns questionamentos sobre uma possível aderência política do projeto em relação aos processos que a capital paulista vivenciava no período. Uma parcela da crítica calçou seus argumentos no fato de o projeto Arte/Cidade estar originalmente ligado ao governo estadual, por meio de um convite da Secretaria de Cultura a Brissac. Segundo eles, o envolvimento do poder público poderia se explicar pelo in teresse em apropriar-se de manifestações artísticas e culturais com vistas a promover a cidade. De fato, esse movimento existiu em diversas situações no mundo da arte contemporânea, e teve um forte impacto nos anos 1990 , quando as cidades passaram a disputar simbolicamente uma posição de destaque na economia globalizada.

Peixoto, op cit, 1997, p. 80

\section{ARTE/CIDADE 2: CURADORIA E CONTEXTO}

A partir do panorama esboçado - da arte, da cidade e da crítica -, será preciso tecer ainda algumas considerações sobre a segunda edição do Arte/Cidade de 1994, na qual Rubens Mano realizou a obra detetor de ausências. Especialmente quanto às intenções curatoriais de Brissac e as especificidades daquele contexto urbano na cidade de São Paulo. De antemão, A cidade e seus fluxos não oferecia um determinado espaço expositivo, mas uma zona imprecisa, de escala metropolitana, representada por um "espaço entre" edifícios que marcavam sua extensão: o prédio da Light, a antiga sede do Banco do Brasil e o edifício Guanabara.

Nesta segunda edição, a abertura para a cidade fez com que seus participantes confrontassem outros desafios: ao invés de trabalhar num espaço protegido que garantisse uma situação especial para a fruição dos trabalhos, como o conjunto edificado do antigo Matadouro, a escolha da curadoria impunha uma área de fluxo visualmente ruidosa, com sobreposição de diversos extratos de circulação intensa, cujas travessias eram feitas por olhares fugazes perante a metrópole, opostamente a uma disponibilidade do olhar para a apreensão das obras em locais institucionais protegidos e codificados.

O projeto curatorial do Arte/Cidade 2 elegera, assim, uma situação de movimentação intensa da cidade de São Paulo, característica de sua metropolização. O entorno do Vale do Anhangabaú acumula extratos de diferentes escalas de trânsito e circulação urbana; nele estão contidos um rio histórico canalizado, vias expressas de fluxo automobilístico intenso, dois viadutos que transpõem o vale e um extenso parque com pequenas áreas ajardinadas, cuja superfície seca possibilita o deslocamento peatonal entre o centro novo e o centro velho. Além disso, o vale expressa um espaço de cruzamentos historicamente ligado ao crescimento da cidade, ao representar a geografia primordial de São Paulo, 
sendo o Viaduto do Chá a sua construção fundamental. ${ }^{191}$ Nas palavras do arquiteto Angelo Bucci:

Eles representam os dois elementos fundantes da nossa cultura construtiva. Geografia primordial porque no Anhangabaú comparecem condensados elementos recorrentes da base física da implantação da cidade: a várzea e o patamar de terra firme e, junto deles, todos os valores e ocupações típicas que se imprimiram a cada um. Construção fundamental porque o Viaduto do Chá equivale, simbolicamente, à superação. Durante os seus três primeiros séculos de existência, a cidade de São Paulo esteve restrita ao seu sítio de implantação inaugural, no chamado "triângulo histórico" ao leste do Anhangabaú [conhecido por "centro velho"]. Depois disso, [...] a cidade lutara para vencer a dificuldade imposta pela dramática geografia da garganta do Anhangabaú [...], durante um século a cidade inteira sonhara com a passagem em nível. ${ }^{192}$

Voltar o olhar novamente para a historicidade deste lugar, que foi relegado por décadas, parecia ser um ponto crucial para se pensar aquela cidade.

A complexidade do contexto urbano escolhido para a realização do Arte/ cidade 2 também abarcava a condição momentânea das três construções que delimitavam o raio de alcance do projeto: todas elas se encontravam em estágio de reconversão de uso, uma vez que tinham sido relegadas ao abandono por décadas, em decorrência da evasão do centro histórico de São Paulo por empresas e pelo próprio poder público. Por trás disso, emergia um processo estratégico de revalorização da zona central da cidade após um longo período

191 O Viaduto do Chá é um símbolo da conquista do homem sobre a natureza acidentada do território paulistano, e que ainda se encontra no imaginário arquitetônico. A primeira construça data de 1892 foi concelida por Jues Martin: a segunda versão do viaduto, e que persiste até hoje, foi proje-

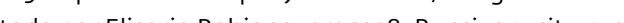
192 Ibidem, pp. 33-34. de "obsolescência programada". Pensar nos fluxos da cidade, portanto, não se restringia a provocar um deslocamento espacial no território, mas convidava a pensar os processos históricos envolvidos na configuração daquela região primordial da cidade e seus significados atuais.

Ao mesmo tempo, instaurado num lugar de trânsito, o segundo Arte/Cidade exigiu do público uma disposição peatonal para alcançar os trabalhos, ao percorrer a distância entre os três edifícios envolvidos. Ao longo dos percursos, o público não só se deparava com as obras realizadas para o projeto; seu deslocamento implicava a fruição da paisagem urbana, atravessado pela grande perspectiva do vale.

Ao invés de uma localização, a situação aportada aqui era a de um deslocamento, um transitar entre as coisas. Mas, para o curador da mostra, não se tratava de simplesmente criar um percurso de um lugar para o outro; a ideia era "produzir um movimento que afetasse simultaneamente todo o espaço". ${ }^{93}$ Inúmeros caminhos eram possíveis. A situação buscada exigiria que o público tomasse parte do fluxo urbano, como pretendia seu idealizador.

Sobre a edição do Arte/Cidade 2, parte da crítica especializada reagiu à época com ressalvas, e por vezes identificou no projeto as evidências de uma relação problemática entre arte e percepção urbana. Para alguns, o embate fundamental dos fluxos metropolitanos acabou por coibir a arte de sua potência estética (em outras palavras, a curadoria se sobressaia aos trabalhos e a escala da cidade os amortecia).

Aos olhos de Lorenzo Mammì, "curiosamente, os artistas que mais se deram bem foram aqueles que mais resistiram à aceleração imposta pelo ambiente, propondo peças que exigem um olhar demorado, uma certa suspensão temporal". ${ }^{194}$ Iole de Freitas, Arthur Lescher e Waltercio Caldas são os exemplos citados pelo crítico de arte, sendo que todos eles tinham obras expostas em recintos fechados "protegidos".

193 Peixoto, Nelson Brissac. Arte/Cidade: a cidade e seus fluxos, op. cit., 1994, s.p.

94 Mammì, Lorenzo. Novo"Arte/Cidade" fica aquém do esperado, O Estado deS. Paulo, Cultura, 8 out. 1994, p. Q1. 
Aqueles que optaram por sair às ruas, segundo Mammì, acabaram incorrendo em redundância, e só reafirmaram o que já estava embutido na tese central do projeto. "Postos no meio do trânsito, colocados de maneira a estimular a atenção flutuante do público, [os trabalhos] tenderam a acelerar ainda mais o fluxo, remetendo freneticamente a outros espaços, ou inventando gags visuais instantâneas". ${ }^{195}$ De acordo com o crítico, Rubens Mano foi um dos raros artistas que tiveram êxito em lidar com a escala metropolitana:

Entre os artistas que mais se expuseram ao movimento convulsivo da cidade, o único a ter encontrado o tom certo me parece ser Rubens Mano, com seus dois holofotes apontados contra os passantes do Viaduto do Chá. Luz fortíssima, que realça e ao mesmo tempo queima as figuras, sublinha e apaga o movimento. ${ }^{196}$

Na mesma direção, a crítica de Alberto Tassinari considerou que a escala do Anhangabaú teria inibido a intensidade estética da grande maioria dos trabalhos: "O clima é repetidamente lúdico, como se as obras tivessem imitado as proezas - malabarísticas, eletrônicas, e tantas outras - que se espalham pelos calçadões e galerias do centro da cidade. Do simplesmente lúdico para o estético, porém, poucos dão bem o salto". ${ }^{197}$

No primeiro Arte/Cidade que se abria francamente à cidade, não foi simples - e isso é compreensível - enfrentar aquela escala imensa. Conforme ponderou a crítica de arte Lisette Lagnado, "a tarefa de estabelecer uma relação entre os dois enunciados do projeto, isto é arte e cidade, coloca uma exigência primordial: obra e espaço devem propiciar a impregnação física de um no outro". ${ }^{198}$ Porém, segundo ela, nem todos os artistas se despuseram a

\section{Ibidem.}

977 Tassinari, Alberto. Escala do espaço parece ter inibido intensidade estética, O Estado de S. Pallo, Cultura, 8 out. 1994. p. O1. Culcura, 8 out. 1994, p. $Q$

198 Lagnado, op. cit. enfrentar o problema; dentre os raros artistas que encaram a urbe para valer, Mano aparece novamente como um exemplo de relativo êxito:

as instalações mais atentas à escala da cidade não foram realizadas pelos artistas plásticos. É o caso do fotógrafo Rubens Mano, autor do fascinante projeto de iluminação, detetor de ausências [...]. À noite, a luz destes poderosos faróis atravessa horizontalmente os pedestres do Viaduto do Chá, projetando suas sombras e multiplicando a questão do anonimato. ${ }^{199}$

Percebe-se aí que nem os artistas nem tampouco os críticos estavam habituados a lidar com a realidade "não-institucional", em espaços extramuros. De certa forma, o projeto de Brissac abriria um caminho potente a se explorar, pelo qual Rubens seguirá despontando como um dos artistas mais interessantes e contundentes da geração paulistana. 
detetor de ausências (1994) 
O convite para participar do Arte/Cidade 2 representou a oportunidade para Rubens de, pela primeira vez, incidir diretamente no dia a dia da metrópole, como um acontecimento em si. Para tanto, Mano elegeu o Viaduto do Chá como situação disparadora para elaborar sua proposição. Na descrição do projeto, Mano definiu aquele lugar como um "eixo visível de um intenso cruzamento entre homens e máquinas". ${ }^{200} \mathrm{~A}$ intervenção urbana (ou "interferência”, como prefere nomear o artista neste caso) ${ }^{201}$ consistiu em um dispositivo luminoso que atravessava o viaduto perpendicularmente ao fluxo normal de automóveis e pedestres. À noite, os fachos de luz delimitavam alternadamente as silhuetas de quem por ali passava desapercebido. A obra, assim, se instaurava na duração de um acontecimento espaço-temporal, que só se completaria pela experiência do atravessamento dos raios luminosos. ${ }^{202}$

O dispositivo criado por Rubens era composto de dois grandes holofotes de 12 mil watts de potência cada, instalados em ambos os lados do viaduto. Apoiados sobre torres de 13 metros de altura, a partir do nível do vale, os cilindros emitiam fachos de luz paralelos, de 1,5 metro de diâmetro, que cruzavam perpendicularmente o caminho dos carros e dos pedestres no viaduto. As fontes luminosas foram posicionadas em sentidos opostos, fazendo com que a luz se propagasse pela paisagem do vale e se dissipasse na imensidão da cidade, ao fundo.

200 Rubens Mano apud Santos, op. cit., 2004

201 Apesar de Mano fazer uma distinção entre intervenção e interferência - tomando esta como a adição de um dispositivo temporariamente, sem alterar o espaço fisicamente -, optei por utilizar o termo intervenção para as três situaçōes propositivas analisadas neste eixo, uma vez que todas me pareceram mais afirmativas do que ruidosas, já que potencializam a percepção de questões imbricadas naqueles contextos. Em sua dissertação de mestrado, intervalo intransitivo, o artista optou por não abordar detetor de ausências em suas análises do período justificando que este teria um caráter de " "interferência". mais que intervenção Aqui porém, ele será tomado como um desdobramento entreo "l har fotográfico a a ão"intervencionista" no mesmo espaço-tempo do espectabr.

(c) tos artistas de vanguarda dos anos na experiência da vida urbana. 


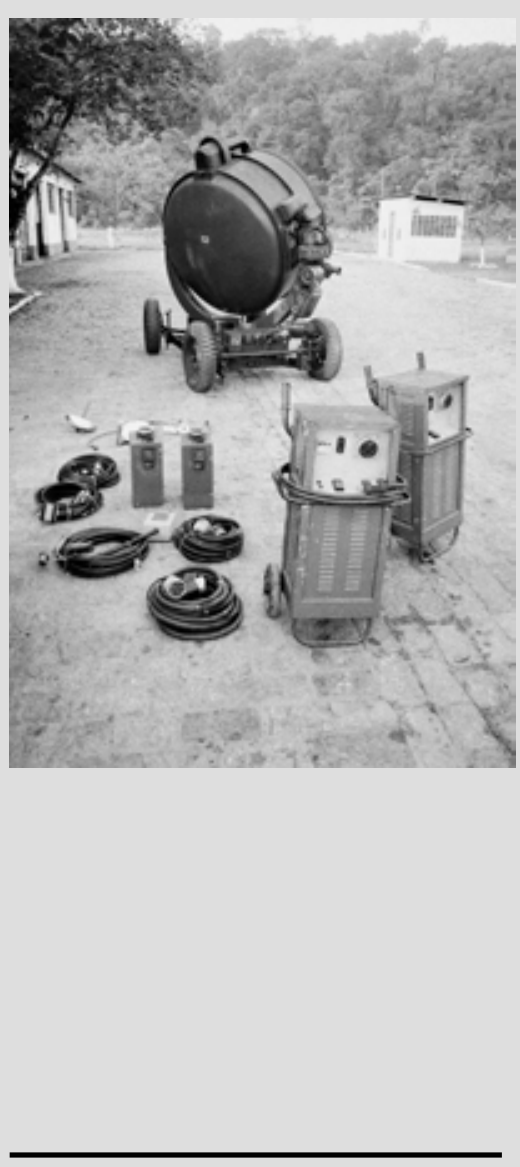

FIG. 18 Detalhe do conjunto de

equipamentos que acompanhavam os refletores militares. Foto: Rubens Mano.

FIG. 19 Teste com o refletor militar no

litoral paulista, 1994. Foto: Rubens Mano.

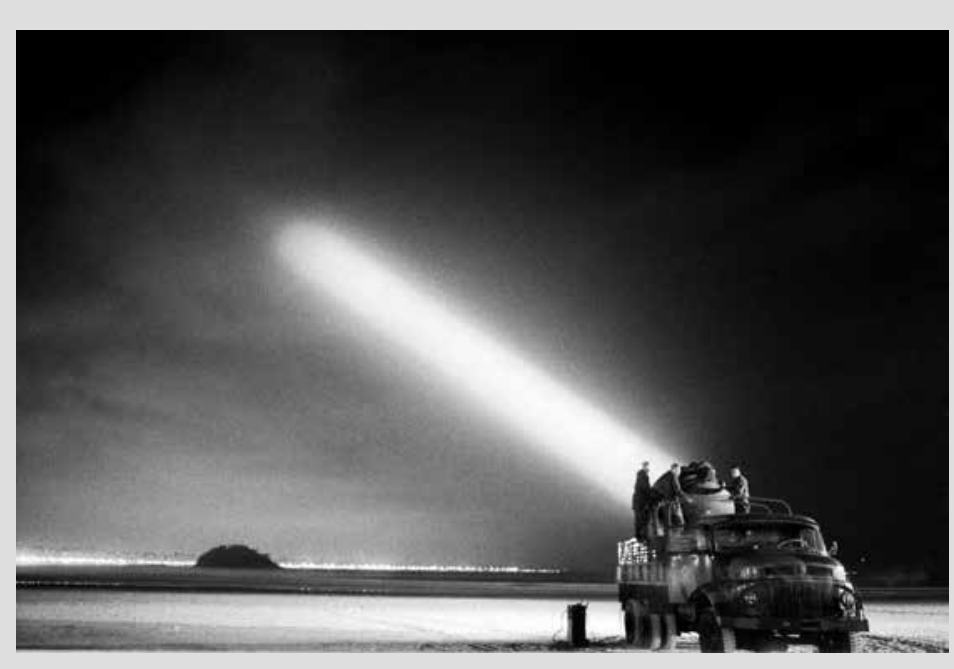

Lidar com tal escala metropolitana não é uma tarefa simples. O desafio foi em parte vencido por Rubens ao encontrar em equipamentos militares a calibragem ideal para intervir num lugar tão fluido e impreciso, como o Viaduto do Chá, de intensa circulação e ao mesmo tempo incrustado no vazio urbano do vale. Em sua habilidade para negociar com diferentes agentes e fornecedores, sugerida desde a viagem às terras andinas, Mano convenceu o Exército brasileiro a emprestar dois holofotes (fig. 18) utilizados na II Cuerra Mundial para identificar aviões em ataque. ${ }^{203}$

Na oportunidade de falar sobre seus trabalhos, durante o encontro "Tropico na Pinacoteca”, organizado pela revista Tropico e pela Pinacoteca do Estado de São Paulo, em maio de 2002, e que reuniu, além de Rubens, o filósofo Celso Favaretto e a crítica de arte Lisette Lagnado em torno do tema É possivel hoje uma crítica institucional?, o artista projetou imagens dos testes que havia feito com os holofotes militares no litoral paulista à época (fig. 19). No relato sobre o encontro, Fernando Oliva comenta tal projeção como uma "obra à parte": "em ambiente lunar, espécie de cenário para uma ficção científica contemporânea, Mano e seus assistentes aparecem próximos a um caminhão, que tem na caçamba um dos projetores, lançando em direção ao céu um gigantesco raio de luz branca”. ${ }^{204}$

Rubens conta que, além dos holofotes, foi preciso correr atrás das lâmpadas disponíveis no mercado; consegui-las foi, segundo o artista, o grande diferencial do projeto:

Era uma peça rara e cara. Aqui no Brasil só existiam quatro, custavam U\$ 1.500,oo cada uma, e eu não conseguiria comprar com o dinheiro do projeto. Mas ao convencer a Osram a me ceder duas dessas lâmpadas, sendo que usaria somente a metade da vida útil delas, fiquei com

$203 \mathrm{Na}$ ficha técnica da obra, publicada no livro Intervençōes urbanas: Arte/Cidade, organizado pelo curador Nelson Brissac Peixoto, em 2002, consta que o artista foi buscá-los na base militar de Praia Grande.

204 Oliva, Fernando. A discussão que reuniu o artista Rubens Mano e os críticos Celso Favaretto e Lisette Lagnado, Tropico, seção "Em obras", 2002. Disponível em: <http://p.php.uol.com.br/tropico/ html/textos/1254,1.shl>. Acesso em 6 dez. 2017. 
uma ótima moeda de troca para oferecer a alguma outra empresa. E foi dessa maneira que eu consegui com que a Quanta me emprestasse os ballasts, os cabos, e os estabilizadores. ${ }^{205}$

Com isso, o único gasto durante a produção do trabalho foi com a construção das torres para suspender os projetores. Essa característica de envolver e articular diversos profissionais para a realização da obra - por meio da elaboração de uma argumentação e da construção de uma parceria que culmina no projeto executado - é projetada pelo artista como um procedimento análogo ao urbanismo, obra como urbanismo, onde certas possibilidades dependem do deslocamento para além do artístico, do pensar e fazer arte.

O entendimento de Mano sobre o significado ampliado de sua obra coincide, de certa forma, com o que Brissac pretendia instaurar com o projeto Arte/Cidade: um novo lugar de atuação do artista e a realização da obra como "pretexto" para se ampliar os horizontes da prática artística contemporânea, envolvendo "um espectro maior de situações", "uma maior riqueza de aportes", "um diálogo mais amplo" ao lidar com "um número maior de tensões" em relação a contextos já destinados a uma atividade artística.

A obra detetor de ausências, tal como outras realizadas nessa mesma edição do Arte/Cidade, partiu da luz como matéria fundante, por meio da qual o artista reconfiguraria a experiência daquele lugar. Por sua natureza, a obra funcionaria em sua máxima potência no período noturno. Até mesmo a iluminação pública da Eletropaulo foi rebaixada para se criar a condição ideal de realização do trabalho. ${ }^{206}$ Durante a noite, ao atravessar os fachos luminosos, o transeunte tinha seu contorno demarcado instantaneamente, sem que ao menos houvesse tempo para que sua sombra fosse projetada. A obra se refazia a cada passante, numa alternância luminosa entre ausência e presença.

205 Trecho extraído da entrevista realizada em seu ateliê, em 3 de agosto de 2015

206 Consta da ficha técnica da obra, publicada no livro Intervençẽes urbanas: Arte/cidade, organizado por Brissac em 2002, agradecimentos à Eletropaulo, o que confirmaria a colaboração entre a empresa e o artista.

\section{A EXPERIÊNCIA DA DURAÇ̃̃O}

Se no capítulo anterior o conjunto de obras de Rubens Mano, nomeado "imagens performáticas", pressupunha a experiência do artista em deslocamento pela cidade, em detetor de ausências a experiência de deslocamento é atribuída ao sujeito-perceptor. Ou melhor, a potência estética do trabalho está em fazer do transeunte a um só tempo sujeito e objeto da intervenção, ampliando com isso o sentido da prática artística. Algo que já se insinuava, como visto, na fotografia de 1987 (fig. 1).

A transformação do sujeito usuário do espaço em sujeito perceptor do lugar corresponde à valorização da situação nômade discutida no primeiro conjunto de obras, que trazia os percursos realizados pelo artista na cidade. A experiência nômade da vida urbana permite perceber a proposição de Rubens mais como experiência do que como obra. A arte, nesse caso, é capaz de interromper o fluxo do cotidiano da cidade ao deslocar o olhar do sujeito de sua condição passiva para uma nova situação perceptiva, ativa, por meio da qual constrói um outro lugar. A obra detetor de ausências se coloca, portanto, como um dispositivo perceptivo mediador, entrelaçando artista, público e lugar.

No limite, a obra só alcançaria sua plena realização na duração da experiência do sujeito perceptor, que a vivenciaria através do deslocamento do seu corpo no espaço. Para a crítica de arte Thais Rivitti, o desafio da participação do público se apresenta em vários trabalhos de Mano (incluindo calçada e vazadores), mas tem lugar especial na intervenção de 1994. O fato de a obra só se consumar no contato com o público, segundo ela, evidencia um certo limite para a ação artística, que "depende sempre de uma disponibilidade imprevisível do público para ocorrer". ${ }^{207} \mathrm{Na}$ entrevista de 2003 , Rivitti chega a indagar o artista sobre tal disponibilidade necessária por parte do público, ao que Rubens justifica:

Acredito que os trabalhos a princípio entrem no espaço urbano como uma oferta qualquer: sem divulgação, convites, ou qualquer anúncio

207 Rivitti, op cit, 2003. p. 
prévio. Não costumo criar expectativas em relação aos projetos, e tampouco imagino essas ações como propostas transformadoras. Penso nelas como inserções "silenciosas" que não procuram provocar qualquer descontinuidade à paisagem. Apenas sugerir, através de um processo de ressignificação dos espaços, a presença de outros fluxos contidos no interior do ambiente urbano. São ações que procuram atuar em uma linha limite entre o estar e o não estar na condição de arte. ${ }^{208}$

Sem poder contar com a certeza de que o público tenha vivenciado suas obras "silenciosas", instaladas temporariamente na cidade, Mano não hesita em documentá-las rigorosamente, como se o registro tivesse tanto valor quanto a própria obra. Uma das fotos de detetor de ausências mais reproduzidas na mídia e em artigos sobre o Arte/Cidade foi uma tomada de cima de um edifício circunvizinho. O ponto de vista do alto explicita o espaço em ato ao flagrar a aparição luminosa de transeuntes que circulavam anonimamente pelo viaduto.

Vista do alto, é possível perceber como a intervenção incide no espaço-tempo do lugar, produzindo um novo lugar; este, por sua vez, é qualificado pela presença-ausência de seus transeuntes, que reporta a uma aparição ambígua e fantasmática de habitar a metrópole. O local passa a ser percebido não mais como um lugar determinado por suas construções e sua fisicalidade, mas pelo que nele se manifesta como um acontecimento transitório, na duração da ação no espaço-tempo da cidade.

A mesma fotografia também revela a preocupação do artista em contextualizar a situação urbana da intervenção, fazendo aparecer diferentes extratos de circulação no enquadramento daquele trecho do Viaduto do Chá. Curiosamente, o formato final da fotografia é novamente quadrado, pelo qual o aspecto paisagístico do contexto urbano enquadrado é transformado, agora em segunda ordem (imageticamente), em uma nova situação, artística e objetualizada.

208 Ibidem

\section{A DISSOLVÊNCIA DA FOTOGRAFIA}

Quando nos deparamos com os escritos críticos sobre A cidade e seus fluxos, publicados à época, boa parte deles qualifica o trabalho de Rubens a partir de sua natureza fotográfica, inclusive ao se referir a Mano como fotógrafo, e não como artista, tal como Lisette Lagnado o fez em seu artigo sobre o Arte/Cidade citado anteriormente. Partindo-se do princípio que a concepção geral de detetor de ausências baseia-se na inscrição do sujeito na cidade por meio de registro fugaz promovido por uma fonte luminosa, pode-se supor que o emprego da luz como matéria principal da obra deriva, no caso de Mano, da formação do seu olhar pela fotografia. É preciso, então, investigar como a fotografia se insinua em detetor e no que ela se dissolve como expressão.

Arrisca-se dizer que a matriz fotográfica de Mano deixou resquícios na intervenção de 1994 sob três aspectos: como técnica, ao se utilizar a matéria-prima luz para produzir um registro, mesmo que instantâneo; como linguagem, às avessas, abandonada a pretensão de se criar um registro documental, permanente; e como recurso mediador, entre habitat e habitante, ou mais precisamente, entre uma situação urbana que perdeu a escala humana e a individuação dos seus usuários ao se reinterpretarem naquele lugar.

Do ponto de vista da técnica, a interferência luminosa no Viaduto do Chá reporta à utilização do recurso luminoso como meio procedimental e expressivo para se deter, ainda que por instantes, a imagem dos entes circulantes, em especial do pedestre. Os feixes de luz, de 1,5 metro de diâmetro, "englobavam o corpo dos passantes quase que por inteiro; e quem se posicionasse em uma vista intermediária, viria pessoas aparecerem e desaparecerem, fixados na retina como fotografia fugaz". 209

209 Souza, Gabriel G. E. de. Percepçōes e intervençōes na metrópole: a experiência do projeto Arte/Cidade em São Paulo (1994-2002). Dissertação (Mestrado) - Escola de Engenharia de São Carlos EESC-USP. São Carlos, 2006, p. 115. 
Fisicamente, a opção pelo recurso da projeção de luz, por sua natureza, parece ter sido a maneira mais factível de vencer a escala urbana do viaduto, por sua ação propalada no espaço. Ao mesmo tempo, o dispositivo luminoso etéreo é incapaz de reter uma imagem de algo ou alguém; ele ilumina o ente no espaço, mas não é capaz de registrá-lo. O suposto "fracasso" dessa operação fotográfica reitera a impossibilidade de reter a presença dos corpos naquela paisagem, e por extensão, na cidade. Tal impossibilidade de se registrar a imagem poderia ser analisada como uma inversão da fotografia uma "não-fotografia", que estaria em correspondência com a dimensão efêmera da presença do sujeito na grande cidade.

O fenômeno é descrito por Laymert dos Santos com precisão:

Atingido pelo facho, o passante se ilumina por um momento, antes de voltar à escuridão; mas se ilumina de um modo muito peculiar: metade luz, metade sombra, seu corpo perde o volume, esvaindo-se ao mesmo tempo na superexposição e na sombra que se alonga e se perde, como o próprio facho, no fundo da cidade. Aparecimento e desaparecimento são, assim, concomitantes e complementares. O acontecimento, porém, não termina aí: mal o passante reconquistou sua dimensão habitual, e já está entrando no facho que o apanha no sentido contrário, fazendo agora de sua metade luz, sombra, e de sua metade sombra, luz. Aparecimento e desaparecimento ocorrem então simultânea e sucessivamente. ${ }^{210}$

Orlando Maneschy identifica o princípio fotográfico de detetor como um aparato mecânico à semelhança dos "antigos jogos de ilusão, como lanternas mágicas, ou ainda às máquinas de tomadas de silhuetas, os desenhos fotogênicos", ${ }^{211}$ em que o resultado imagético não era nem retratos com identidade, nem possuía perenidade.

\section{Santos, op. cit., 2004}

The Runo e os fluxos luminosos. II Encontro de História da Arte. Campinas: IFCH/Unicamp, 2006, p. 367.
É nesse sentido que a intervenção luminosa de Mano apontaria, segundo Brissac, para

a tentativa de resguardar as coisas da desaparição. [Ela] alude aos primórdios dos processos fotográficos, pela ausência do registro fotossensível, dado pelo papel. O abandono da pretensão ao registro, à catalogação, típica do fotojornalismo, é indispensável à percepção desses entes fugidios. ${ }^{21}$

Como linguagem, ou contrafotografia, o dispositivo nos reporta à fotografia s/ título [contracampo] de 1987 (fig. 1), mencionada na Introdução desta tese. A obra dos anos 1980 traz uma paisagem desfocada, em preto e branco, cuja continuidade é interrompida por uma espécie de "buraco" luminoso intenso e perturbador. "O foco luminoso não é um reflexo e sim uma reflexão, posto que se trata de um holofote ligado e voltado para o espectador". ${ }^{213}$ Posicionado no chão e voltado para o espectador, o holofote de Mano mira para algo que está fora do campo do registro. A inversão do foco fotográfico fora do campo, realizada por Mano, produz como resultado um contracampo, que tem como centro o observador.

Tudo se passa, então, como se o sujeito-objeto da imagem que se vê não fosse aquilo que se encontra à nossa frente, mas sim um corpo real que entrou no raio de ação do holofote e passa a ser por ele iluminado: o corpo do fotógrafo e, também, o do espectador. Presente embora ausente esse corpo real-virtual se faz imagem fora da imagem, fora do campo, no contracampo. ${ }^{214}$

212 Peixoto, Nelson Brissac. Luz. Paisagem urbana, op. cit., p. 50.

213 Santos, Laymert Garcia dos. A tecnoestética de Rubens Mano. Politizar as novas tecnologias. São Paulo: Editora 34, 2003, p. 208

214 Ibidem. 
Além disso, de acordo com Maneschy, a introdução do holofote se apresenta como um campo de ausência, uma vez que o círculo branco do canhão luminoso corresponde a áreas brancas na superfície do papel fotográfico não "queimadas". Ou seja, "naquele lugar correspondente na película fílmica [... imprimiu-se uma imagem tão densa que, no momento em que a película é exposta para fazer a cópia, a luz é impedida de atravessar estes pontos de densidade". ${ }^{215}$

Doze anos depois, em depoimento à Maneschy, o artista reconhece a relevância desta contrafotografia para os trabalhos desenvolvidos dali em diante.

A importância dessa imagem só vai se confirmando com o tempo [...] Ela acabou ficando como uma concentração de repertório. Ela não trazia de primeiro todas estas questões, mas, com o passar do tempo, ela passa a ter mais sentido do que quando foi produzida. ${ }^{216}$

A fotografia de 1987 representaria, assim, uma espécie de "grau zero" desse movimento de deslocamento do foco no campo visual da fotografia para a inclusão do espectador enquanto parte do trabalho. Mesmo que não pertençamos à cena no ato do registro da imagem, a alteração da paisagem a partir da inserção do holofote nos inclui na obra, como o reflexo do espelho o fez na obra dos pintores holandeses do passado, convocando o público a se reconhecer na cena, como parte integrante da composição. Tal deslocamento da posição do observador se dá igualmente em detetor. Neste caso, ele já não é um registro fotográfico ipsis literis, mas uma virtualidade luminosa.

Como dispositivo mediador, o projeto para detetor de ausências já trazia uma intenção de pôr em relação a aceleração da cidade com a ideia de presença/ausência do homem nela. No projeto, Rubens justifica a opção pela luz ao referir-se a ela como potencializadora da velocidade na cidade ao mesmo

215 Maneschy, op. cit., 2006, p. 365.

216 Rubens Mano apud ibidem, p. 366 tempo que enfrentaria o homem com sua representacão. ${ }^{217}$ Os feixes de luz expressariam a própria experiência desmaterializada dos espaços de fluxo na cidade, onde a alternância entre ausência/presença do sujeito é um índice de sua transitoriedade.

As análises do curador Nelson Brissac sobre a intervenção de 1994 também incluíram a analogia entre luz e impermanência do sujeito na cidade: "Esses feixes de luz indicam a situação do indivíduo na metrópole: permitem que ele veja, mas também evidencia sua precariedade. As sombras dos passantes se projetam sem que lhes seja permitido qualquer registro. São uma constatação do seu lado anônimo". ${ }^{218}$

Ao mesmo tempo, a fotografia possibilita, segundo o curador, "reatar o contato do indivíduo com o urbano", ${ }^{219}$ colocando a escala da representação diante do espaço urbano, e recuperando a escala humana perdida naquele contexto.

Segundo Maneschy, a obra de Mano revela:

a inviabilidade de uma permanência desses corpos inscritos na luz, desvelando a dimensão do humano diante da cidade [...]. Diferentemente dos processos históricos que utilizaram o fluxo luminoso para registrar um retrato, Mano lança mão do mesmo princípio para revelar que somos figuras anônimas na multidão da metrópole. ${ }^{220}$

O Rubens fotógrafo, assim, deixa de atuar num campo restrito ao meio, trazendo a "matéria" luz e seus procedimentos para o espaço tridimensional. detetor seria a expressão inaugural dessa passagem, onde o processo fotográfico, cuja essência reside no elo privilegiado com o real, lhe assegura um

217 Ao permitir ver e identificar, a luz "indicará também uma espécie de anulação de todo indivíduo que cruzar os cilindros, visto que sua sombra evanescente revelará a impossibilidade de qualquer registro dessa passagem". Rubens Mano apud Santos, op. cit., 2004

218 Peixoto, op. cit., 1994

219 Peixoto, Nelson Brissac Luz, op. cit., pp. 50-51.

220 Maneschy, op. cit., 2006, p. 367 
acesso particular à experiência do espaço. Daí que sua atividade nuclear (fotográfica) despontará como uma construção plástica na forma de objetos e instalações em projetos futuros, inscritos - desde as imagens realizadas no início da década de 1990 - no novo movimento de hibridização de meios da arte contemporânea.

\section{DESREALIZAÇÃO DA CIDADE, DESLOCALIZAC̣ÃO DO SUJEITO E DESLOCAMENTO DA OBRA}

Sob o vetor contemporâneo da vida urbana, pelo qual os circuitos globais sobrepuseram ao "espaço de lugares" o "espaço de fluxos", onde as coisas tendem a se liquefazerem, a realidade sofre um processo de erosão e uma parcela do espaço (da cidade), por sua vez, se desrealiza, ocasionando, como exposto anteriormente, uma fragmentação do território.

As análises sobre a transformação da cidade e da nova sociedade em rede tecidas pelo sociólogo espanhol Manuel Castells ajudam a entender o panorama de substituições, derivado da organização imposta pela nova economia global: "a economia global/informacional é organizada em torno de centros de controle e comando capazes de coordenar, inovar e gerenciar as atividades interligadas das redes de empresas. Serviços avançados [...] estão no cerne de todos os processos econômicos". ${ }^{221}$ Dispersando-se pelo território, elas ocasionam uma ocupação fragmentada e difusa.

Nas cidades globais, cujas características também se fazem presentes em São Paulo, os centros correspondem a bolhas de concentração de espaços lisos e homogêneos, cuja aparência é igual em todas elas (efeito "bigness") - por exemplo, a paisagem dos centros empresarias instalados na capital paulista, nas regiões da Berrini e da Faria Lima, com edifícios altos, espelhados, "inteligentes” e autossustentáveis, ou seja, sem constituir cidade ao redor.

221 Castells, op. cit., p. 405.
O mesmo fenômeno de desrealização é descrito por Laymert dos Santos no texto sobre detetor de ausências, publicado no catálogo do Arte/Cidadez. Para o autor, ele abarcaria tanto a arquitetura e seus construtos quanto as instâncias da urbanidade e da sociabilidade do sujeito na cidade:

A arquitetura vai subtraindo o volume dos edifícios, escondendo-o nas superfícies espelhadas que se refletem indefinidamente; ou, então, transformando as fachadas em painéis luminosos, que ecoam os outdoors se expondo e se impondo ao longo das avenidas. [...] Os muros crescem e as guaritas proliferam; as ruas cedem lugar às pistas por onde transitam automóveis com os vidros fechados, protegendo os passageiros contra os excluídos que assediam nos sinais de trânsito; o comércio abandona as calçadas, refugiando-se no espaço asséptico e policiado dos tempos do consumo; as praças e jardins vão sendo gradeados, para impedir que os miseráveis neles se amontoem [...]. A cidade está se desrealizando, ao deixar de ser ponto de encontro e espaço de socialização: nas camadas superiores, as interações interpessoais ocorrem por telefone, fax, celular e correio eletrônico. Malha viária urbana se sobrepõe às redes de comunicação interativa e às redes de televisão - a cidade se transfere para o campo eletromagnético. ${ }^{222}$

O que antes era empregado como invólucro do edifício - a saber, o vidro ${ }^{223}$-, num ideal de integração entre o dentro e o fora (enunciado pela cortina de vidro da arquitetura moderna de Mies van der Rohe), agora se transforma em espelhamento, criando uma superfície virtual e "dissimulada" sobre o volume real. O que antes era projetado como solo comum e público, pela utopia modernista, valorizando a livre circulação, agora é circunscrito e condenado ao encarceramento de grades, muros, câmeras de vigilância, segurança privada e carros

222 Santos, op. cit., 1994

223 Este mesmo tema do vidro será visto mais adiante, por ocasião das análises sobre a obra vazadores. 
blindados. O que antes existia na cidade como centralidade, entendida como o núcleo espacial onde se dá o encontro e se realiza plenamente o sentido público, agora é intermediado por monitores, telas multitouch e aplicativos interativos.

Aos olhos de Laymert, a desrealização da cidade, e do espaço urbano, trouxe como consequência a experiência de deslocalização de seu habitante em sua vivência na cidade, na qual não é possível mais distinguir uma cidade da outra, pois elas estão cada vez mais iguais. Tal processo tem início notadamente na experiência com os aeroportos e os hotéis, semelhante à experiência do não-lugar de $M$. Augé, e em seguida com os shopping centers e as cadeias de fast-food. A abertura dos mercados teria acarretado um processo de estandardização de parcelas da cidade - mesmas imagens, marcas e produtos (e, mais, segundo Koolhaas, mesma arquitetura, impessoal) - que faz com que o sujeito se descole do lugar, apenas transite, alienadamente.

É a partir da substituição da experiência do real por simulacros, "imagens de vida real fetichizada", que Laymert lê o trabalho de Mano. Segundo o crítico, haveria dois processos correndo paralelamente no trabalho e fruto dessa experiência: enquanto a cidade se desrealiza (espaço virtualizado) a imagem da cidade torna-se o real (imagem real). Em detetor de ausências, ao perceber a sua própria condição de deslocalização no fluxo intenso do Viaduto do Chá, o artista busca demarcar aquele lugar, paradoxalmente a partir de um dispositivo luminoso intangível, fundindo, segundo o crítico, fotografia e espaço numa única experiência.

Visto de fora, de longe, ou vivido de dentro, o detetor de ausências funcionava como um sensor captando a deslocalização do habitat e do habitante da megalópole, registrando a sua transferência para o plano da imagem; como se o artista quisesse fundir a câmera fotográfica com o próprio espaço urbano fotografado para, assim, fazer uma espécie de fotografia imanente, isto é, uma fotografia que mostrasse, integradas numa experiência única, a criação do espaço e a criação da imagem desse espaço. ${ }^{224}$
Recuperando mais detidamente a formação do tecido urbano da cidade de São Paulo, especialmente a região central (e primordial) no entorno do Viaduto do Chá, percebe-se que o fenômeno da desrealização daquele espaço urbano não é herdeiro somente da arquitetura do Bigness, nem da homogeneização de marcas, mas de um processo histórico característico da capital paulista sobreposto a uma tendência mundial de aceleração, disseminada pelos espaços de fluxos do mundo global. A obra detetor de ausências fundaria, assim, a experiência particular paulistana da escala metropolitana - o anonimato do ser urbano nômade - somada à da virtualidade de um tipo de paisagem urbana que constitui as cidades globais.

Rubens parece querer, sobretudo, sinalizar (literalmente, com holofotes) a experiência de transitoriedade do sujeito na cidade, no trânsito entre as velocidades da cidade moderna e da pós-moderna.

A fim de contrapor à formulação da experiência transitória de Mano, entre o moderno e o pós-moderno, entre o espaço e a imagem de espaço, poder-se-ia citar a obra de Ana Maria Tavares, artista da mesma geração, cuja boa parte de sua produção reconfigura a experiência embriagante da virtualidade, do não-lugar, do Bigness, em diversos trabalhos realizados entre os anos 1990 e 2000. Um dos exemplos eloquentes dessa experiência é a instalação Cityscape (figs. 20 e 21), de 2010.

A obra foi concebida para a exposição Bienal 50 Anos, mostra comemorativa do cinquentenário da Fundação Bienal, realizada em São Paulo. Nela, Tavares se beneficiou de uma fachada de vidro em frente ao espaço da obra, instalada no interior do Pavilhão da Bienal. Ali, a artista criou um ambiente de sala de espera, com bancos de inox e um painel espelhado, sob o qual inscreveu palavras como "lexotan", "credit" e "sparkling". A superfície espelhada do painel refletia o pano de vidro de Niemeyer mutuamente, misturando o dentro e o fora e confundindo a realidade de ambos.

Tal como Mano, uma das principais características da produção de Tavares é a ideia de participação na obra, neste caso convocando o público a vivenciar um "espaço de estar", numa experiência imersiva conformada por um ambiente mobiliado e sonoro. Diferentemente de Mano, a artista recorre 

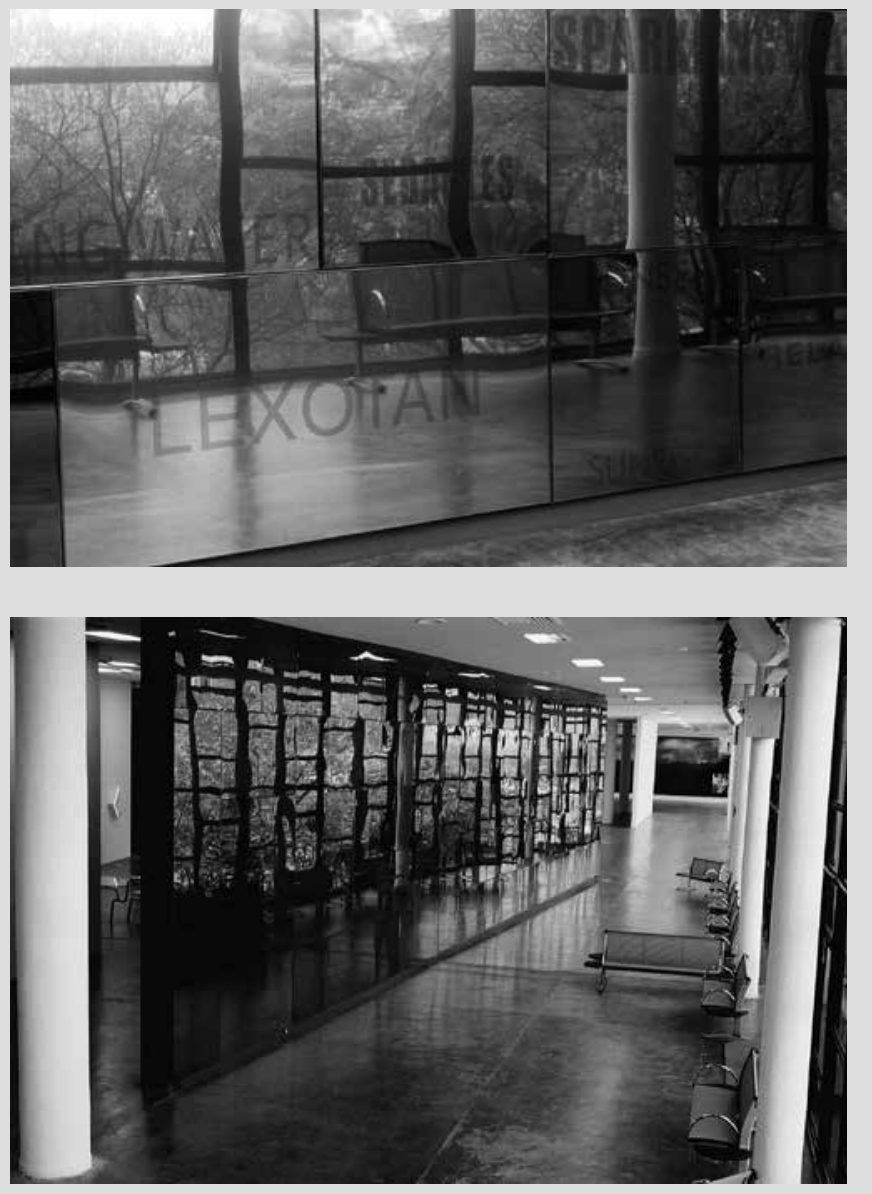

FIGS. 20-21 Ana Maria Tavares.

Cityscape (Parede AMT para Niemeyer),

2001

Instalação com painel em aço inox

colorido e gravado, MDF, alumínio

bancos de inox; peça sonora, sensores

de presença e caixas acústicas, total 125

$\mathrm{m}^{2}$ (a parede é composta por 72 painéis,

medindo 4,75 × 22,8 $\times 0,4 \mathrm{~m}$ ). Vista

parcial da instalação na Bienal 50 Anos,

Pavilhão Ciccillo Matarazzo. Fotos: Ci:

Pavilha Ciccillo Matarazzo. Fotos: Caio

Reisewitz (imagem abaixo); Carlos Kipli

(imagem acima) quase sempre a materiais industriais de ponta, que também fazem parte do repertório arquitetônico do bigness: aço inox, vidro, superfícies espelhadas e insulfilm. Por meio deles, Tavares projeta um espaço liso, ao mesmo tempo embriagante e angustiante, respectivamente por sua profusão de espelhamentos e por sua generalidade, onde "nada" acontece, a não ser a espera.

Ambos os artistas, cada um a seu modo, reconfiguram a experiência de deslocamento que opõe dialeticamente o real e o virtual, o espaço e a imagem de espaço. Tanto a experiência instantânea do atravessamento da luz quanto a experiência embriagante dos ambientes espelhados são modos possíveis de aproximação da arte à cidade, e vice-versa, que reagem à experiência contemporânea da vida urbana nas grandes cidades.

Aqui, é Laymert novamente que traz uma análise precisa sobre habitar a megalópole, para o qual haveria três possibilidades: viver o processo de deslocalização sem questionar (espectador-consumidor); viver o processo em sua carga negativa (habitante-filósofo); ou viver o processo como positividade. ${ }^{225} \mathrm{Em}$ última instância, é pela perspectiva da positividade que o posicionamento de Rubens Mano em relação à cidade se faz potente. Em detetor de ausências, o espaço em ato produz um efeito contrário ao desenraizamento do sujeito; nele, o artista converte os espaços de trânsito da vida urbana "supermoderna" em locais de experiência, transformando esses espaços em atos de espacialização. 
calọada (1999) 
Como já mencionado ao longo desta tese, Rubens Mano elaborou algumas considerações teóricas sobre a sua própria prática artística através da pesquisa de mestrado. Na sua dissertação intervalo transitivo, Rubens explicita que a partir de 1990 sua produção é mobilizada pela percepção de três fenômenos urbanos próprios do período: aceleração, deslocalização e desenraizamento. Tais terminologias deixam evidente o diálogo que o artista estabelece com o crítico de arte Laymert dos Santos quanto às suas percepções sobre o fenômeno urbano contemporâneo.

Porém, nem só a cidade vivia tais processos. Por meio da obra calçada, segunda situação a ser estudada neste conjunto, perceber-se-á como a arte e suas instituições também partilham o processo de desenraizamento no mundo urbano atual, especialmente no que diz respeito ao contexto paulistano. $O$ pontapé inicial para a elaboração da obra calçada foi dado por Rubens a partir da constatação de que o local para a sua realização (neste caso, um centro cultural da rede municipal) tinha pouca ou quase nenhuma conexão com o que acontecia do outro lado do muro que delimitava seu espaço institucional.

Tratava-se da Oficina Cultural Oswald de Andrade, um dos equipamentos da Secretaria Municipal de Cultura de São Paulo. O grande edifício neoclássico da rua Três Rios, onde outrora funcionara a antiga Escola de Farmácia no bairro do Bom Retiro, foi tombado pelo Condephaat na década de 1980 e em 1986 recebeu sua nova vocação que perdura até hoje: um espaço para abrigar oficinas culturais. Em 1990 o equipamento, que antes era chamado de Oficinas Culturais Três Rios, foi rebatizado como Oficina Cultural Oswald de Andrade, e passou a representar um dos polos culturais mais importantes da região central da cidade. O centro cultural oferece uma série de oficinas gratuitas nas áreas de música, artes visuais, dança e teatro, e como tal tem um público cativo, de feição especialmente jovem. Seu entorno é ocupado pela miscigenação típica do bairro do Bom Retiro, que, historicamente, recebeu ondas distintas de migração - desde os primeiros judeus e árabes protagonistas do comércio local, passando pela migração nordestina, até chegar nos coreanos e bolivianos, que configuram o mosaico social mais recente. 
Em 1999, a convite da instituição para realizar uma obra nas dependências da Oficina, Mano optou por propor cinco diferentes trabalhos que lidavam com as configurações espaciais e institucionais do local, numa perspectiva "site-oriented". Todos eles receberam os nomes de seus sítios - calçada bueiro (já abordada no primeiro conjunto), telhado, parede e porão, sendo que este último foi o único não executado.

Ao reuni-los sob o título geral de f:(lux)os, o artista assinalava seu interesse em revelar certos circuitos encobertos pelo dia a dia do edifício, e do bairro por extensão, bem como em suscitar outros fluxos não institucionais inscritos sobre o lugar, expressos anteriormente, a partir de fontes de luz energia elétrica. Na definição de Mano, tais intervenções eram "fluidas e discursivas, mais do que fixas e diretas". ${ }^{226}$ Com a mesma sutileza que é de praxe nas proposições do artista, essas inscrições luminosas se espalharam pelo edifício do centro cultural e pelo seu entorno, e se misturaram às estruturas já existentes.

\section{CONECTIVIDADE}

Apesar do intenso movimento local impulsionado pelo comércio diurno, o vaivém das ruas no quadrilátero da Oficina não se mostrou garantia para promover os usos do equipamento público no bairro. Quem passa diante da entrada principal do centro cultural não necessariamente o percebe como tal e nem se dispõe a usá-lo. A pouca conexão entre o espaço aberto da rua e o espaço fechado do edifício foi a pedra de toque para a criação de calçada, considerada por Rubens a principal instalação do conjunto das cinco proposições.

Durante a elaboração das propostas, já norteado pela falta de transversalidade entre as instâncias pública e privada, Rubens se deparou com a exis-

226 Rubens Mano apud Tone, Lilian. Rubens Mano on Light and Power. Disponivel em: <www.mit. edu/ allanmc/liliantonez.pdf $>$. Acesso em 6 nov. 2017. tência de um comerciante de vinis que se instalava diariamente em frente às oficinas culturais para vender música. ${ }^{27}$ Ao perceber uma condição desfavorável à exposição dos produtos daquele (uma vez que trata-se de mercadorias sonoras e não apenas físicas), o artista decide prolongar a eletricidade da instituição (pública) até a calçada, a fim de que o ambulante pudesse tocar seus discos. E, assim, analogamente, tantas outras atividades pudessem se beneficiar da obra do artista.

Através de tubulações metálicas, Mano prolongou a rede elétrica do edifício até o passeio público, em frente ao centro cultural. Ao longo da extensão dos conduítes, o artista instalou tomadas pelas quais disponibilizou energia elétrica gratuita aos usuários das oficinas e aos transeuntes do bairro que por ali circulavam, 24 horas por dia, durante seis semanas.

À precisão com que as obras de Mano são elaboradas muitas vezes corresponde um único elemento, ${ }^{228}$ nesse caso o conduíte metálico; este era capaz de responder às diversas configurações que o trabalho assume entre o pátio externo do edifício e o espaço da calçada. Isto quer dizer que, em calçada, como em muitas outras intervenções propostas pelo artista, não há um sentido compositivo da obra, mas uma positividade afirmativa estruturada pelo elemento e/ou dispositivo empregado na transformação daquele lugar.

Se, por um lado, a materialidade escolhida em calçada tem uma "aplicabilidade" direta no intuito de convocar as pessoas do entorno a usufruir daquele dispositivo e habitar aquele lugar, por outro, ela também traz reminiscências de um repertório arquitetônico de formação. O modo como o elemento metálico se instala sobre as paredes e muretas ao longo do jardim até alcançar a rua lembra um procedimento típico da arquitetura moderna paulista, que privilegiou a "verdade dos materiais" e das estruturas em detrimento de

227 Mano, Rubens. O espaço enquanto imagem projetada [palestra do artista]. São Paulo: Escola . -

ém a luz, em detetor, a tinta branca, em white cue, o tijolo, em imanente, dentre outros elementos. 
escondê-los atrás de paredes, pisos e tetos. Essa solução construtiva de aparência arquitetônica moderna paulista misturou-se na intervenção de Mano às estruturas fixas existentes, confundindo-se a elas e por vezes passando despercebida. Como se nota, é um risco que Rubens não hesita em correr.

A escolha dos pontos eletrificados foi definida pelo mapeamento realizado por Mano sobre aquele território, que buscou perceber os usos e vocações do lugar - incluindo seus usuários e sua sazonalidade - a exemplo dos estudantes de música que, nos intervalos de aula, tinham o hábito de se reunir nas escadarias que dão acesso ao edifício para ensaios fortuitos ${ }^{229}$ (e, como tais, mapeados como possíveis "usuários" da obra).

Como vimos no primeiro conjunto, a "escuta" do lugar, qual seja sua disponibilidade em apreendê-lo, é uma prática recorrente do artista, por meio da qual busca compreender as características do contexto - físicas, culturais e sociais - e dali extrair sua potencialidade como trabalho de arte. Tal estratégia nos leva novamente ao reconhecimento de sua prática arquitetônica, cuja atividade pressupõe um engajamento com o contexto, hoje em dia cada vez mais assentado numa dimensão antropológica. Por sua vez, essa mesma dimensão reverbera com intensidade nos referencias teóricos tomados em sua pesquisa de mestrado, a exemplo dos autores já citados Maffesoli e Augé

Na palestra realizada na Escola da Cidade, em 2009, o artista expressa a sua preocupação em intensificar as trocas entre o que estava dentro e o que estava fora. Ao perceber a ausência de transversalidade entre o espaço aberto (rua) e o espaço fechado (institucional), sua obra deveria criar uma conexão entre eles. A alternância entre as duas instâncias remonta à dialética recorrente entre os espaços abertos e fechados na cidade, problemática comumente perseguida na obra do artista, principalmente a partir dos anos 2000. Em calçada, mais do que isso, ela implica uma interdependência entre ambas onde uma se alimenta da outra e se modifica, infinitamente. Na instalação de 1999, assim, a dinâmica das trocas entre o dentro e o fora, entre o sistema

229 Mano, op. cit., 2009 da arte e seus públicos, alude às trocas simbólicas verificadas na cidade, entre o público e o privado.

\section{A ADESÃO DO PÚBLICO}

Não só o papel institucional está em questão, mas também a efetividade das trocas entre as atividades artísticas ali desempenhadas e o sujeito-perceptor da obra (ou, para usar o termo do próprio artista, o operador/perceptor). A energia elétrica serve, assim, como pretexto para cativar os passantes do entorno e convocá-los a perceber a instituição, e a experimentar a arte.

A obra do artista, mais do que estender o alcance "público" das qualidades do centro cultural e facilitar as vendas do ambulante, revela uma comunicação incipiente entre a instituição e seu entorno, entre seus praticantes e seus possíveis ouvintes. A adesão à obra, a partir de seu uso efetivo e funcional, levaria a uma possibilidade de reconhecer a existência da arte naquele lugar - e, por conseguinte, sua natureza -, e de se efetivar o fluxo entre os dois mundos, divididos pela grade de ferro.

Em calçada, Mano parece jogar com uma inversão de papéis: o que era público passa a ser privado (calçada) e o que era fechado (centro cultural) passa a ser franqueado ao público. Porém, ao invés de relegar a apropriação das calçadas pelos ambulantes, como uma tendência a "privatizar o público", mais produtivo é tomar a obra como um pretexto para convocá-los a participar ativamente daquele lugar (de arte) - no exemplo do vendedor, trocando energia por musicalidade. A própria mercadoria sonora passa a ser uma espécie de atrator do sujeito que transita naquele quarteirão do Bom Retiro, um convite para (re)conhecer aquele espaço público institucional.

A dimensão do uso, e da transformação do uso, está no cerne do trabalho. Conta Rubens que, além do vendedor de vinis, um grupo de taxistas que ali fazia ponto também usufruiu da fonte de energia para ligar uma televisão. Durante a vigência da instalação, o fornecimento de energia 24 horas por dia possibilitou a extensão do horário de trabalho para alguns ambulantes do 
entorno, que passaram a trabalhar à noite. A cidade é, assim, praticada no instante em que seus protagonistas a transformam, alterando e ressignificando seus códigos de uso corrente. E, dessa forma, ela se faz viva e dinâmica.

Aos olhos da crítica de arte Lilian Tone, "calçada dialoga com uma mudança recente fundamental no papel do espectador na arte contemporânea, notável na omnipresença de modos 'não-convencionais' e abertos de abordar o público". ${ }^{230}$ Uma arte que, segundo ela, não se instala em uma posição de autoridade em relação a sua audiência, numa relação intimidante com o espectador; mas, ao contrário, pressupõe-se como uma obra aberta que se completa na figura de um espectador interessado. O trabalho de Mano estaria, portanto, no rol das "obras que inspiram o espectador a realizar seu próprio senso de autoridade, fazer uso de seus direitos e opções, que incluem a opção de se envolver e contribuir". ${ }^{231}$

Aqui, como em tantos outros trabalhos de Rubens, a proposta se completaria na percepção do público e em sua disponibilidade para uma certa ação, mais do que simplesmente sua contemplação. Ao se instalar no fluxo entre o espaço da cidade e o espaço da instituição, o espaço da obra se realiza como espaço entre no momento em que é ativado pelo público, transformando-se em espaço em ato. O deslocamento proposto pelo trabalho, ao constituir uma espécie de lugar no trânsito entre dois lugares, associa o espaço institucional da arte ao espaço aberto da cidade. Tal como aponta a pesquisadora Fernanda Albuquerque, aqui "a relação proposta não é de exterioridade com a obra, mas de implicação mútua”. ${ }^{232}$

230 "pavement also speaks to a recent fundamental shift in the role of the viewer in contemporary art noticeable in the pervasiveness of un-conventional, open-ended modes of addressing the audience". Tone, op. cit.

231 "[...] works that inspire the viewer to realize his or her own sense of authority, to make use of his or her rights and options, which include the option to be engaged and to contribute". Ibidem.

232 Albuquerque, Fernanda. Práticas artísticas orientadas ao contexto e crítica em âmbito institucional. Tese (Doutorado em História da Arte) - Instituto de Arte da UFRGS, Porto Alegre, 2015, p. 93.

\section{O ESPACCO “ENTRE”}

A ideia de "espaço entre" na produção de Rubens implica o atravessamento entre espaço fechado e espaço aberto. Do ponto de vista da arquitetura, ela pressupõe um espaço de transição - principalmente entre espaços público e privado -, e foi formulada como um dos problemas centrais do campo arquitetônico no último Congresso Internacional de Arquitetura Moderna (СIAM), em 1959, realizado em Otterlo. Um dos seus principais formuladores foi o arquiteto holandês Aldo Van Eyck, membro do grupo TEAM 10, cujo protagonismo naquele congresso foi decisivo para uma frente crítica sobre os preceitos modernistas funcionalistas. Naquela ocasião, Van Eyck lançou o conceito de espaço "in-between", por meio do qual buscava promover um fluxo contínuo entre dois lugares.

De acordo com a arquiteta e pesquisadora Ana Barone,

Sua proposta estava no estabelecimento de uma arquitetura que desse conta dos espaços de transição, lugares onde as polaridades pudessem interagir. Como exemplo, ele propõe a reflexão sobre uma porta, como limite entre duas situações antagônicas: dentro e fora. Sua ideia era interpretar a porta não mais como um limite, mas como, ela mesma, um espaço, um lugar em que as polaridades "dentro" e "fora" pudessem se esfumaçar e se interpenetrar para gerar uma nova consciência espacial. ${ }^{233}$

Na palestra “Is Architecture Going to Reconcile Basic Values?", proferida por Van Eyck em 1959, o arquiteto busca o sentido de conciliação dessas polaridades conflituosas, que, no limite, se dariam entre o indivíduo e a sociedade, o habitante e a cidade:

233 Barone, Ana Claudia Castilho. Team 10 - arquitetura como crítica. Dissertação (Mestrado em História e Fundamentos da Arquitetura e do Urbanismo) - Faculdade de Arquitetura e Urbanismo - FAU-USP, São Paulo, 2000, p. 65. 
O homem ainda respira tanto dentro como fora; quando a arquitetura vai fazer o mesmo? [...] Nós simplesmente não podemos respira apenas numa direção - podemos aguentar prender a respiração por apenas um tempo muito curto. A arquitetura moderna tem se esforçado em respirar apenas para fora sem respirar pra dentro - e isso é tão sufocante quanto o contrário -; em todo caso, o resultado é o mesmo. Você não pode abrir sem fechar. Você não pode simplesmente dividir fenômenos duplos em polaridades [...]. Estabelecer o "inbetween" é reconciliar as polaridades conflitantes. Proveja o local onde eles possam trocar e você restabelecerá o fenômeno duplo original. [...] Por exemplo: o mundo da casa, comigo dentro e você fora, ou vice-versa; há também o mundo da rua - a cidade - com você dentro e eu fora, ou vice-versa. Entenda o que quero dizer: dois mundos chocando-se, sem transição. O indivíduo em um lugar, o coletivo, em outro. Entre os dois, a sociedade em geral, lança muitas barreiras, enquanto os arquitetos em particular são tão pobres de espírito que fornecem portas de dois centímetros de espessura e seis pés de altura. [...] Toda vez que passamos por uma porta como essa, dividimo-la em dois - mas não reparamos mais. Essa é a realidade de uma porta? [...] Uma porta é um lugar feito para uma ocasião que se repete milhões de vezes na vida entre a primeira entrada e a última saída. ${ }^{234}$

234 "Man still breathes both in and out; when is architecture going to do the same? [...] We simply cannot breathe only one way - we can hold our breath for only a very short time. Modern architecture has been trying hard to breathe only out without breathing in - and that is just as stifling a thing to do as the opposite - at any rate the result is the same. You cannot open up unless you enclose. You can't just Split dual phenomena into polarities and alternate your loyalty from one to the other without causing despair. [ .... To establish the 'inbetween' is to reconcile conflicting polarities. Provide the place where they can interchange and you re-establish the original dual phenomena. [.] Take an example: the world of the house with me inside and you outside orvice versa, there is a s...] the we a of the street - the city - with you inside and me outside or vice versa Cetwhat I mean the world clashing no transition. The individuat on one site, the collective on the other. Between the two, soci-

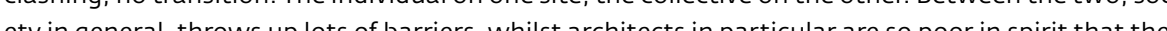
provide doors two inches thick and six foot high. [ ] Every time we pass through a door like that,
A porta, assim, era citada como exemplo de zona de transição espacial e funcional entre o público e o privado, dando lugar à experiência do atravessamento, da transversalidade, da permeabilidade, ainda que em pequena escala.

A figura espacial do in-between de Van Eyck também foi desenvolvida por outros autores, a exemplo de Bernard Tschumi e Julio Arroyo. No primeiro caso, a zona de fronteira entre dois espaços é definida pelo arquiteto suíço mais em termos de contaminação do que simplesmente uma linha divisória. ${ }^{235}$ No caso de Arroyo, ela se expressaria em termos de borda:

o termo borda se associa não só com a ideia de um fechamento que deslinda campos com precisão, como também com um estado ou situação intermediária entre duas áreas ou regiões adjacentes. A borda no espaço arquitetônico é uma franja, uma área ou espaço de borda que se pode produzir e experimentar através de práticas subjetivas como um espaço predominantemente linear. Neste sentido, o espaço de borda se percorre com a consciência de estar em um espaço diferenciado que encerra um lugar [...] ou que separa áreas diferentes, que ficam lateralizadas pelo percurso (borda como trânsito entre lugares). [...] é o limite que marca a abertura ou fechamento para outro lugar distinto, dando lugar à experiência do atravessamento. ${ }^{236}$

Tanto em calçada como em vazadores (proposição analisada a seguir) as situações se definem pelas figuras espaciais da fronteira e da borda - entendida como linha divisória entre dois espaços -, constituídas pelos elementos arquitetô-

we have split in two - but we don't take notice any more. Is that the reality of a door? [...] A door is a place made for an occasion that is repeated millions of times in a lifetime between the first entry and the last exit". Van Eyck, Aldo. Is Architecture Going to Reconcile Basic Values? Neuman, Oscar (ed.). CIAM'59 in Otterlo. Londres: Alec Tiranti, 1967, pp. 27-28.

235 Bernard Tchumi apud Sales, op. cit., p. 141.

236 Arroyo Julio Bordas e espaço púlico. Fronteiras internas na cidade contemporânea, Arquitextos, Sa pavl Ju

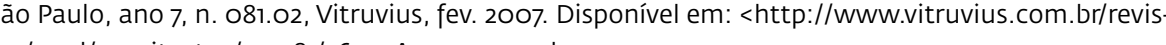
tas/read/arquitextos/07.081/269>. Acesso em 3 dez. 2017. 

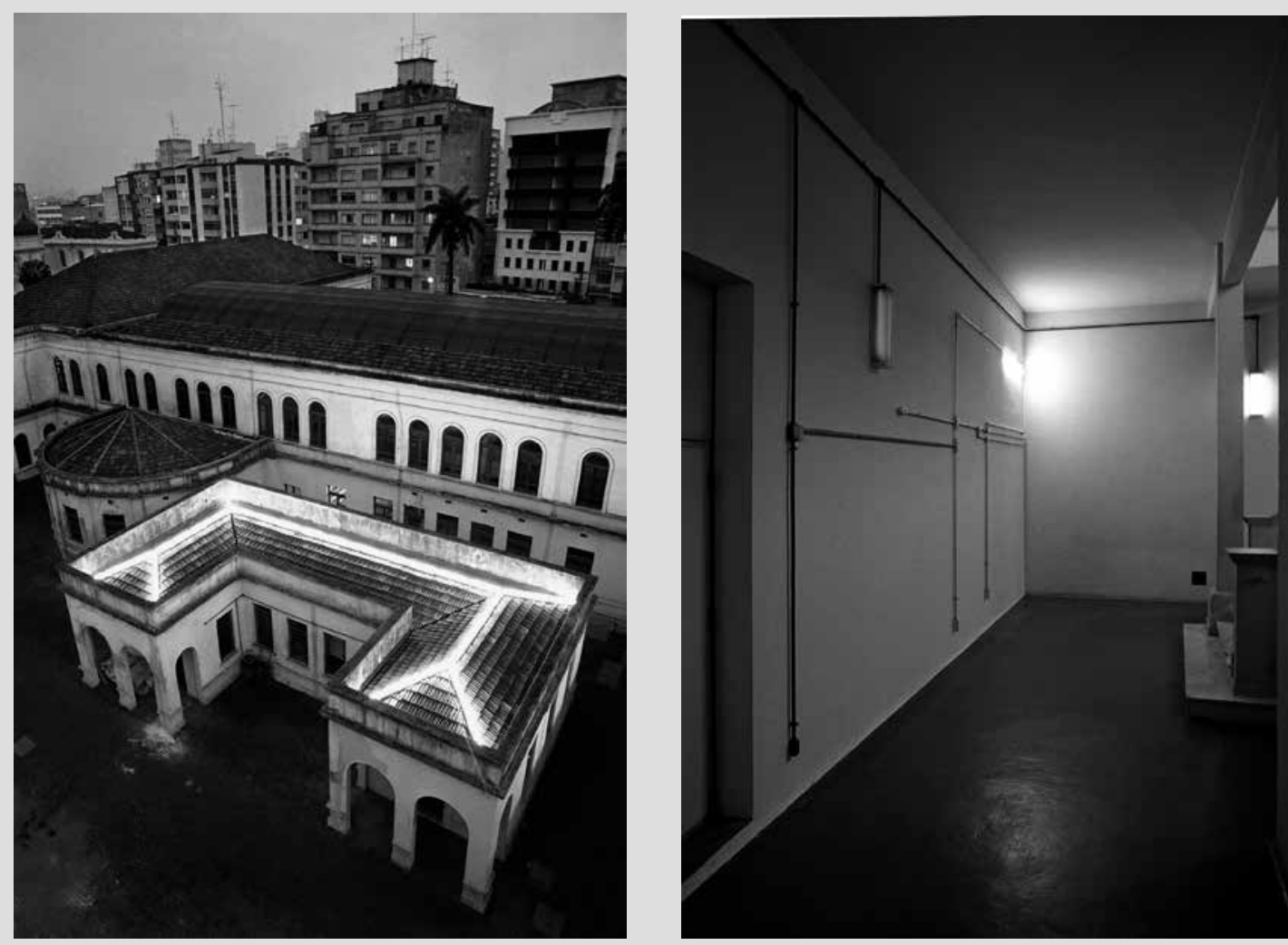

nicos ali encontrados. Ao intervir sobre elas, Mano as dissolve na experiência do atravessamento e faz delas uma obra-arquitetura. Algo que já se insinuava na fotografia de casa verde, porém neste caso ainda restrita a uma apreensão visual da imagem. Lidos como trabalhos in-between, ambas as proposições de Mano procuram estabelecer zonas de contaminação entre o espaço aberto (da cidade) e o espaço fechado (da instituição), e entre o espaço legitimado da arte e o espaço da "não-arte" (das outras esferas da vida cotidiana extra-artísticas).

No exemplo de calçada, paradoxalmente, a adesão à obra parece se cumprir por sua funcionalidade, algo que a arte moderna jamais reivindicou; porém, essa aplicabilidade não teria um fim em si mesma, mas serve como estratagema para algo exterior à própria obra, qual seja a de cativar o público e efetivar a conexão entre o dentro e o fora do mundo da arte, refundando um nexo entre os dois.

\section{OUTROS SÍTIOS}

Na exposição da Oficina Cultural Oswald de Andrade, além de calçada, Mano propôs outras quatro intervenções, com a condição de que o primeiro trabalho fosse a conexão com a rua e que este permanecesse até que a última intervenção se concretizasse. As propostas para bueiro, telhado, parede e porão envolveram em sua maioria a utilização de fontes luminosas endereçadas a estes sítios (estes, localizados dentro e fora do edifício) e pressupunham uma intervenção silenciosa, por vezes quase invisível.

Como bueiro faz parte simultaneamente da série huecos, abordada no Capítulo 2, não caberia desenvolver novamente suas análises aqui. O terceiro trabalho executado foi telhado (fig. 22), por meio do qual o artista instalou um circuito de lâmpadas fluorescentes na cumeeira do telhado do edifício do centro cultural, cujo desenho luminoso refazia a estrutura do elemento construtivo. Durante a exposição, a intervenção podia ser acessada pelo andar superior do edifício vizinho ao edifício principal (havia uma sinalização feita pelo artista para chegar ao terraço, de onde se avistava a obra).

FIG. 22 telhado, 1999

Intervenção com lâmpadas

elétricos. Exposicãa f: e cabos

Cultural Oswald de Andrade
FIG. 23 parede, 1999

Intervença com tubos de metal, cabos

elétricos, lâmpadas, tomadas, caixas,

Exposição f:Cluxuos, Oficina Cultural

Oswald de Andrade 
A terceira intervenção, parede, foi instalada nos corredores internos do edifício. Rubens prolongou estruturas tubulares sobre as paredes (fig. 23), du plicando as estruturas já existentes no local e confundindo sua funcionalidade. A quarta proposta, porão, não foi concretizada, mas supunha igualmente o emprego de matéria luminosa no respectivo sítio, buscando transformar a experiência desse lugar adjacente da arquitetura em local vibrante de luz.

O conjunto de proposições para a Oficina Cultural Oswald de Andrade, tal como em outras intervenções de Rubens, envolveu intervenções sutis e concisas, com economia de materiais e recursos, feitas por uma ação silenciosa, sem prévios alardes. Apesar de visualmente silenciosas, mostraram-se crítica e afirmativamente no espaço: estranhas à paisagem, como pequenas alterações, suas inserções silenciosas aos poucos vão se revelando através de um processo de ressignificação dos espaços, de seus usos, fluxos e narrativas, 
Se detetor de ausências nasce de um princípio de transitoriedade e impermanência do sujeito na cidade, em que a delimitação institucional da arte se sobrepõe espacialmente ao tecido urbano, no caso de calçada, em que os espaços da arte e da vida cotidiana são contíguos, esse fluxo é estressado pelo artista num espaço "entre", entre o centro cultural e a rua, expresso na dissolução da fronteira materializada na grade de ferro, convertida literalmente em suporte para o trabalho. Neste último caso, portanto, a ação de Mano se presta como uma conectividade física e simbólica entre o dentro e o fora, com o propósito de romper com a inércia daqueles espaços por meio da intensificação das trocas entre eles e entre seus usuários.

Algo semelhante se passa em vazadores, intervenção realizada três anos mais tarde, em 2002, para a 25ํㅗㄹ Bienal Internacional de São Paulo. Na proposição endereçada ao prédio da Fundação Bienal, o dispositivo conector já não se evidenciava apenas de um único lado, como na mureta energizada de calçada, mas foi construído como uma passagem entre os lados de dentro e de fora do edifício da bienal. O "corredor" incrustado em uma das fachadas do Pavilhão Ciccillo Matarazzo ligava o espaço expositivo ao espaço aberto, e público, do Parque Ibirapuera. Isso quer dizer que o que antes foi elaborado como uma extensão física da instituição (arte) para a rua (cidade), na bienal se propunha a ser um trânsito mútuo entre os dois lugares, uma permeabilidade totalmente horizontal e não hierárquica, tomando-se a própria arquitetura do lugar. Tanto o visitante da mostra poderia se surpreender com uma saída fortuita ao espaço verde do parque, como o usuário deste poderia esbarrar com uma entrada clandestina para desfrutar de um dos maiores eventos de arte contemporânea do mundo. A fronteira se converteu em espaço fluido (à semelhança da concepção de porta de Van Eyck).

\section{O PROJETO PARA A BIENAL}

A obra vazadores foi parte da proposta de Rubens apresentada aos curadores da 25를 Bienal, Alfons Hug e Agnaldo Farias, em novembro de 2001, em resposta 
ao convite para integrar o Núcleo Cidades, uma das seções mais relevantes daquela edição, cujo tema se voltava às “iconografias metropolitanas”. Den tre as 12 cidades tematizadas nesse núcleo, Mano foi designado pela curadoria para figurar no grupo de São Paulo. ${ }^{237}$

No projeto para vazadores encaminhado à curadoria, Rubens explicou quais eram suas motivações gerais:

A intervenção preparada para a próxima Bienal de São Paulo incide sobre as relações que estabelecemos com o espaço construído, em um contexto absolutamente tomado por estímulos visuais e constantes alterações da paisagem (como é o caso de uma metrópole como São Paulo). [...] vazadores sugere a importância de um olhar crítico também voltado às estruturas e instituições que organizam a metrópole, enfatizando como este acaba por definir nossa ideia de "lugar". Ou como proposições estéticas, aspectos políticos, ramificações socioeconômicas..., podem ser consideradas e alçadas à condição de "sites", desdobrando ainda mais os significados de uma intervenção. ${ }^{238}$

A proposta para vazadores foi articulada em duas partes, previstas para acontecer simultaneamente nos dois pisos reservados ao Núcleo Cidades. Apesar de complementares, Rubens só pôde realizar uma delas.

A primeira parte da ação pressupunha um corte retangular de aproximadamente 2,5 $\times 5$ metros na laje do segundo andar do prédio; no lugar da abertura no piso, seria instalada uma grade alveolar de aço carbono galva-

237 De acordo com a documentação sobre a $25^{3}$ Bienal existente no Arquivo Wanda Svevo da Fundação Bienal de São Paulo o primeiro convite feito pelo curador Agnaldo Farias, em carta datada de 27 de fevereiro de 2001 se referia à participação como representaça brasileira dentro do segmento da representações nacionais: porém, na carta de Carlos Brakte enderecada ao artista, datada de 22 de

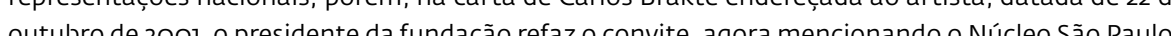
238 Trecho do projeto original consta da documentação sobre a $25^{\mathrm{a}}$ Bienal do Arquivo Wanda Svevo. nizado, semelhante aos respiradouros colocados em calcadas para arejar ambientes subterrâneos, como metrôs e estacionamentos. O corte, porém, não foi autorizado. No texto para o catálogo do Núcleo Cidades, o curador Agnaldo Farias cita o ocorrido: "A primeira proposta de Rubens Mano para a $25^{\underline{a}}$ Bienal esbarrou no órgão de controle do patrimônio do Estado, o Condephaat. Contraditoriamente, o Estado tenta barrar um fluxo avassalador que ele mesmo estimula". ${ }^{239}$ (Supostamente, o curador estaria se referindo à dinâmica intrínseca da capital paulista, de derrubar e construir, a mesma problematizada em casa verde.)

Posto o dilema patrimonial arquitetônico de lado, as análises seguirão pelo caminho propositivo do artista. Abrir um corte na laje no meio do segundo andar do pavilhão conectaria visualmente o pavimento com o térreo; o vetor vertical relacional se posicionaria como contraponto à ordem horizontal da arquitetura do pavilhão, derivada da planta livre corbusiana e do uso primordial do edifício, dedicado aos aparatos industriais nos anos 1950 (é preciso lembrar que a escala monumental do pavilhão decorre de sua vocação industrial: nomeado originalmente como Pavilhão das Indústrias, o edifício foi concebido para abrigar as "maravilhas tecnológicas" produzidas pela indústria paulista à época).

A segunda parte da ação se endereçava a uma das elevações do edifício, na qual o artista propôs uma outra abertura, por meio da retirada de uma parte da caixilharia original do pavilhão e de sua substituição por um "corredor" que atravessaria os limites do prédio. O novo elemento arquitetônico da fachada deveria ser composto por uma estrutura de metal e vidro, idêntica ao vedamento original. A volumetria do corredor de passagem avançaria para fora e para dentro; em ambas as extremidades haveria uma porta de vidro sem qualquer fechadura, cadeado ou catraca que pudesse interceptar o fluxo contínuo entre os espaços. Além disso, não haveria nenhum tipo de sinali-

239 Farias, Agnaldo. São Paulo, ó quão dessemelhante! $25^{\underline{9}}$ Bienal de São Paulo: Iconografias Metropolitanas - Cidades. São Paulo: Fundação Bienal de São Paulo, 2002, p. 250. 
zação que marcasse o dispositivo como uma entrada ou saída da bienal, mas quem o descobrisse poderia acessá-lo "extraoficialmente".

A projeção da experiência do segundo atravessamento foi descrita pelo curador Agnaldo Farias no texto do catálogo:

Um dos módulos da caixilharia que perfaz a fachada menor do prédio da Bienal, aquela que é voltada para o interior do Parque Ibirapuera, projeta-se para fora. O transeunte, mesmo aquele desinteressado da exposição de arte contemporânea que estará acontecendo em seu interior, talvez estranhe aquela construção, talvez se aproxime dela, talvez a examine com cuidado, e quem sabe, note que o vidro que a fecha é móvel, que empurrando-o ele abrirá e terá acesso a um corredor que o levará ao interior do prédio. ${ }^{240}$

De acordo com o projeto de Mano, as intervenções propostas se colocavam próximas de uma relação "fluida e discursiva" e procuravam "trazer uma reflexão quanto às 'impermanências' da vida contemporânea, e um possível 'amolecimento' da superfície enrijecida de nossa realidade material”. ${ }^{241}$

O novo elemento construtivo, em vazadores, recupera um tipo de procedimento já comentado na prática de Mano: a subtração (tal como vimos em casa verde, com o vazio central da demolição; em disponha, com a retirada de parte da carroceria do veículo; ou ainda em bueiro, anulando o vazio com luz branca). ${ }^{242} \mathrm{Na}$ proposição para a bienal, ambos os atravessamentos, mesmo que em projeto, partiram da subtração de uma parcela da arquitetura - piso ou parede, para construir "negativamente" um segundo elemento no edifí-

240 Ibidem, p. 251.

241 Trecho do projeto original enviado à Fundação Bienal, datado de novembro de 2001. O projeto consta na documentação sobre a $25^{\text {a }}$ Bienal do Arquivo Wanda Svevo.

242 Podemos citar aind outras abras ñ̃o abordadas neste estudo cono espaço aberto/espaco fechodo (fig 32) uma fotografia do Pavihão da Bienal, onde este se apresenta penamente vazio, à espera

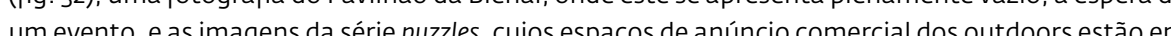
um evento, easimagens da serre puzzles, cujos espaços de anúncioc branco, criando uma espécie de intervalo na paisagem urbana. cio, quer estranho quer idêntico às qualidades materiais e estruturais destes.

A operacionalidade subtrativa de Mano é interpretada pelo crítico Laymert dos Santos em termos de conectividade:

[...] todo espaço fechado, seja arquitetônico ou urbano, é um espaço aberto - basta perceber as suas conexões, não se ater ao corte de fluxo, mas restituir o corte ao próprio fluxo e descobrir ou redescobrir a sua fluência. Em todos esses casos, abrir o espaço significa abrir-se ao espaço da transformação, conectar-se nas conexões. ${ }^{243}$

Se em casa verde a construção negativa proporcionava uma espécie de mirante - isto é, uma conexão visualmente construída, como se o atravessamento daquele lugar privado devolvesse a fluidez do espaço da cidade entre suas instâncias local (da rua) e metropolitana -, no vazador executado para a $25^{\underline{a}}$ Bienal o artista promove um atravessamento físico e simbólico entre o mundo da arte especializado e a vida prosaica de quem frequenta o parque ("vazava-se" pessoas de um lado para o outro, ao mesmo tempo que "vazava-se" arte para o parque e vida urbana, para dentro da bienal).

Ouatro anos após a sua participação na bienal, Mano publicou um texto na revista Urbania, em que analisa retrospectivamente as proposições para ambos os andares:

o projeto considerou a presença de dois "atravessamentos" nas estruturas do edifício projetado por Oscar Niemeyer (Parque Ibirapuera). um físico, construído no andar térreo diretamente sobre uma das fachadas de vidro, e outro simbólico, projetado para o segundo andar do espaço expositivo - materializado somente através de uma maquete eletrônica. [...] enquanto o primeiro "atravessamento" (no térreo) oferecia-lhes uma experiência ligada ao movimento do próprio corpo,

243 Santos, op. cit., 2004 
questionadora da condição de agentes de uma determinada situação, o segundo trazia como horizonte uma reflexão quanto aos condicionados processos de ocupação e construção espacial. ${ }^{24}$

Se pensarmos em termos conceituais de projeto, curiosamente, há uma inversão na descrição inicial de Mano, posto que a proposta para o espaço expositivo do segundo andar envolvia uma alteração concreta na arquitetura do edifício, ou seja, apesar do atravessamento ser apenas visual haveria uma intervenção física com elementos estranhos. Enquanto que, no andar térreo, o atravessamento era literalmente físico, da arquitetura como elemento construtivo e do próprio corpo que o percorreria; porém, foi projetado como mimese do edifício (espaço institucional da arte), anulando-se na aparência vitrificada do pavilhão, por meio do qual "simbolizava" a dissolução entre os dois mundos (o da arte e o da vida).

Assim como calçada, vazadores (ou pelo menos a segunda ação, a que foi realizada) anunciam operações cruciais desenvolvidas na prática artística de Rubens Mano, que implicavam simultaneamente: a arquitetura, neste caso, seus códigos construtivos; o observador, e o corpo deste; e a instituição, como delimitação do lugar oficial da arte. Na primeira instância, o elemento construído transversalmente à fronteira entre a bienal e o parque criava um espaço entre, de livre trânsito, franqueando a passagem entre espaço privado e espaço público. Na segunda, notar-se-á que, para esse fluxo se efetivar, seria preciso que o corpo do observador ativasse o dispositivo ao percorrê-lo de um lado para o outro, ou vice-versa. E no terceiro, transitar livremente entre um lugar e outro implicava subverter as regras institucionais da Fundação Bienal numa espécie de visibilidade paralela. No limite, essa passagem "la teral" devolvia à instituição os pressupostos conceituais da curadoria sobre a problemática das cidades, ao mesmo tempo que os tensionava como utopia.

Ainda assim, essas operações só teriam êxito mediante uma negociação

244 Mano, op. cit., 2006b, p. 109 precisa entre artista e instituição, na medida em que o trabalho dependia de uma discrição absoluta de todas as partes envolvidas para sua plena efetividade. Segundo o artista, era condição sine qua non manter a obra em sigilo afim de não causar alardes nem na imprensa nem no público visitante. Só assim a passagem se apresentaria de fato como uma alternativa extraoficial de livre trânsito entre bienal e parque, diluindo-se as fronteiras.

É a partir dessas três instâncias anunciadas - arquitetura, público e instituição - que a proposição de Rubens para o Núcleo Cidades da 25aㅡ Bienal será analisada adiante, para, por fim, se comentar a polêmica em torno da retirada da obra da exposição, marcando a saída do artista da bienal quinze dias antes do término desta.

\section{A ARQUITETURA (E A OBRA-ARQUITETURA)}

A escolha do lugar para o atravessamento da segunda parte da obra (realizada no térreo) implicou dois aspectos: de um lado, o artista optou pela fachada menos evidente do pavilhão e voltada mais diretamente ao espaço verde do parque, o que em parte resgatava os critérios estabelecidos pelo arquiteto Oscar Niemeyer para a designação da entrada principal do edifício na frente da grande marquise e franqueada ao espaço público de lazer; e, de outro, a passagem de Mano se colocava diametralmente oposta à entrada oficial da 25aㅡ edição, instalada pela Fundação Bienal na fachada de frente para a avenida 23 de Maio.

A escolha de Rubens para o local de sua ação, em si, já implicava uma leitura do artista sobre aquele lugar e sobre os significados daquela edificação modernista. No projeto original de Niemeyer, datado de 1953, o arquiteto determinou o acesso principal do edifício na face voltada para o espaço verde do parque, próximo à marquise central, que, por sua vez, teria a função de conectar todos os volumes projetados para o complexo arquitetônico do parque. Portanto, originalmente, a conexão desejada do pavilhão não era com a via expressa da avenida 23 de Maio (determinada pela instituição, 
em 2002), mas sim com o espaço público de cultura, lazer e recreação do Ibirapuera.

De par com as considerações sobre a escolha da fachada do pavilhão para a realização da obra, é preciso resgatar os significados daquele edifício no contexto em que foi projetado. Tanto o parque quanto o pavilhão simbolizam os vestígios da celebração da cidade nos anos 1950, durante os quais São Paulo selava sua modernidade, metropolização e desenvolvimento. O parque foi inaugurado em 21 de agosto de 1954 como parte das comemorações do $4^{\circ}$ Centenário da capital paulista, que vivia seu momento de efervescência cultural e econômica. "Os olhos do mundo estarão voltados para São Paulo", dizia a frase estampada na capa do boletim informativo n. 2 da Comissão do $4^{\circ}$ Centenário, sinalizando que a São Paulo moderna e industrial queria se mostrar para o mundo.

Essa ambição internacional da cidade se confunde com a história da criação da Bienal de São Paulo, em 1951. Ao implementar uma bienal na cidade aos moldes da Bienal de Veneza, seu mentor, Francisco Matarazzo Sobrinho (mais conhecido como Ciccillo Matarazzo), vislumbrou um passo estratégico para a internacionalização tanto da arte brasileira como da capital paulista. O mesmo Ciccillo foi convidado pelo então governador Lucas Nogueira Garcez para presidir a comissão das comemorações dos 400 anos da cidade, sendo responsável por planejar os eventos. ${ }^{245} \mathrm{O}$ início dos festejos em 12 de dezembro de 1953 coincidiu com a inauguração da $2^{\underline{a}}$ Bienal, que já ocorreria no pavilhão, e que pré-inaugurou o parque (naquele instante, apenas dois dos pavilhões estavam concluídos)

O período da construção do pavilhão da bienal coincide, portanto, com a sedimentação do projeto moderno na arquitetura brasileira, impulsionado pelo poder público. Em entrevista à Fernanda Curi para o blog da Fundação Bienal, o arquiteto Carlos Lemos, colaborador da equipe de Niemeyer, confirmou essa visão: "a partir daquele momento houve a aceitação definitiva da

245 Curi, Fernanda. 60 anos do Parque Ibirapuera, Blog da Bienal, 20 ago. 2014. Disponivel em: <http:// www.bienal.org.br/post.php?i=1089>. Acesso em 31 out. 2017 arquitetura moderna no país. As pessoas se referiam a ela como 'Estilo Bienal'. Depois da criação do Ibirapuera, nenhuma outra obra pública ignorou o moderno na arquitetura". ${ }^{246}$

Tudo isso só reforça o quão pertinente e significativo seria uma edição dedicada a pensar a cidade, e a própria bienal, a partir de sua herança modernista, à luz da problemática urbana contemporânea. Nem São Paulo se fez tão moderna assim, nem a Bienal se identifica a priori como uma entidade local. Desde pelo menos a década de 1970, e mais intensamente a partir dos anos 1990, a capital paulista deixou para trás sua vocação industrial e passou a se reconfigurar como um híbrido, sobrepondo uma cidade de serviços à sua herança burguesa. Somado a esse processo, sob o impacto da economia global - qual seja, a do capitalismo transnacional e das novas tecnologias da informação e da comunicação -, o território urbano sofreu uma tal fragmentação que os espaços de lugares foram aos poucos substituídos pelos espaços de fluxos (conforme assim apontado por Manuel Castells no livro A sociedade em rede, já apresentado nesta tese).

De modo análogo, a Fundação Bienal - e, mais especificamente, o projeto modernista do Parque Ibirapuera e do Pavilhão das Indústrias -, que já nascera como plataforma internacional, parecia perder progressivamente seus vínculos com a cidade e o território, buscando se alinhar cada vez mais a uma rede transnacional virtual, no movimento da internacionalização da arte guiado pelo capitalismo global. Findada a década de 1990, aquela que consolidou a globalização da arte e da cidade, era preciso pensar suas consequências, incluindo aí a crítica ao projeto modernista no país como uma de suas decorrências.

Ao recuperar a memória do projeto arquitetônico do Pavilhão Ciccillo Matarazzo, Mano desvia o olhar sobre a arte - comumente praticado dentro do espaço expositivo legitimado como o da bienal - para um olhar sobre as questões arquiteturais impressas no projeto modernista e esquecidas tanto

246 Carlos Lemos apud Curi, op. cit. 
pela instituição quanto pela curadoria daquela edição da bienal. vazadores representou, assim, uma desconstrução de códigos espaciais, reagindo aos conteúdos simbólicos presentes naquele exemplar da arquitetura moderna local. O deslocamento propiciado pela obra, ademais, abria um fosso entre as implicações vivenciais decorrentes do projeto modernista dos anos 1950 para aquela cidade e o projeto curatorial da $25^{\underline{a}}$ Bienal, centrado na questão metropolitana. (O que será abordado mais à frente, nas análises que confrontarão a concepção curatorial e a concepção do artista.)

No artigo publicado na revista Urbania, em 2006, Rubens coloca os termos da relação da sua obra com a arquitetura local:

A dimensão da arquitetura foi referência importante para o trabalho, uma vez que o edifício reitera a utopia modernista de sugerir uma integração com seu entorno - visível na forma como está suspenso (sobre pilotis) e no uso da fachada de vidro, intensificando a relação interior/ exterior. ${ }^{247}$

Rubens parecia indicar que, mesmo apesar das intenções modernistas de Niemeyer, o uso que se fazia do espaço negaria a sua própria vocação integradora moderna (contrariada, inclusive, pela cobrança de ingresso, que limitava o alcance público de uma exposição daquela envergadura). ${ }^{248}$ Sabemos que de fato a utopia desejada pela arquitetura moderna não se realizou, não só no complexo edificado do Ibirapuera, mas em muitos outros projetos, culminando com Brasília em 1960. ${ }^{249} \mathrm{~A}$ intervenção arquitetônica promovida com vazadores escancara a contradição entre o edifício e seus usos, a distância entre o lugar e o lugar praticado, entre o programa arquitetônico moderno e o tipo de vida urbana que isso produziu na cidade.

247 Mano, op. cit., 2006b, p. 109

248 O fim da cobrança de ingresso para as bienais de arte veio na edição seguinte, em 2004, a partir da qual a mostra tornou-se definitivamente gratuita.

249 O tema será objeto de investigação no Capítulo 4, a partir da obra futuro do pretérito.
De par com as implicações da obra quanto à historicidade moderna do edifício, vazadores também pode ser entendido como uma obra-arquitetura. Ainda no artigo de 2006, Rubens deixa claro sua consciência sobre o novo estatuto do trabalho: "por pretender uma correspondência com o espaço construído e promover um diálogo com o ambiente urbano dentro do campo da arquitetura, considero que parte das ações realizadas também pode ser entendida como arquitetura". ${ }^{50}$

De acordo com os pressupostos projetuais modernos, a modulação dos pilotis e a planta livre possibilitam uma liberdade para posicionar as aberturas de um edifício; daí os desdobramentos da ampla utilização do pano de vidro, conhecido como um dos cinco pontos da arquitetura corbusiana. Num ideal de integração com a natureza e de permeabilidade entre os espaços abertos e fechados, Niemeyer também empregou os fechamentos em vidro no Pavilhão das Indústrias. Rubens soube se apropriar desses elementos construtivos modernos para propor silenciosamente no lugar um atravessamento físico e simbólico daquele edifício. Utilizando-se de vidro e ferro para armar a estrutura do atravessamento do térreo, materiais idênticos aos da fachada original do prédio, o artista mimetizou a arquitetura (fundindo obra e arquitetura) e anulou a fronteira que ela estabelecia entre a arte e a cidade (sendo a cidade figurada pelo espaço público do parque municipal).

Na mimese com a arquitetura, o novo elemento construtivo proposto por Rubens na fachada do pavilhão levanta uma reflexão sobre as possibilidades e os limites da ação artística no tecido da cidade: de um lado, o próprio trabalho se colocava no limite entre arte e "não-arte"; de outro, a experiência do atravessamento no térreo pressupunha que o público já tivesse vivenciado a experiência dos fluxos na cidade. Trazer esse repertório significante do viver urbano na cidade era parte das intenções do artista.

A passagem de Mano apontava, assim, para o alargamento das reflexões propostas pela curadoria da 25ํㅗㄹ Bienal, ao criar uma situação de enfrenta-

250 Mano, op. cit., 2006b, p. 104 
mento real entre a cidade e suas representações. A ação foi minuciosamente pensada para se apropriar do local da mostra e pôr à prova a opção curatoria pelo tema da metrópole. E é sob esse aspecto que residiria uma dimensão política no trabalho do artista: a produção de espaço, neste caso, decorrente dos atos de espacialização que trazem à tona a dimensão de um espaço culturalmente construído.

A proposição do corredor "disfarçado" em arquitetura trazia em seu bojo, portanto, duas dimensões: a desconstrução e a desarticulação dos códigos espaciais que organizavam aquele lugar e, ao mesmo tempo, a desmaterialização da ideia de obra, ao concebê-la como simulacro do próprio pavilhão. A dissimulação da obra em arquitetura tensionava uma visualidade repertoriada pela arte contemporânea, que incluía seus pressupostos de apreensão e fruição da obra.

Em decorrência do procedimento mimético e de uma desierarquização entre as noções de obra e site, Fernanda Albuquerque ressalta que a segunda ação de vazadores exigiria uma atenção redobrada por parte de quem a observa:

Ao utilizar os mesmos materiais da construção, a estrutura realizada pelo artista mimetizava a arquitetura, de tal modo que a percepção do trabalho, para o qual não havia qualquer sinalização ou identificação, necessitava uma certa dose de atenção e envolvimento. ${ }^{251}$

\section{O PÚBLICO}

Uma vez que a produção do espaço se mostrou central na obra de Mano, o deslocamento da posição do espectador é crucial na formulação dessas experiências-obras; nelas, o espectador embarcaria num espaço-fluxo, a partir da qual reformularia a sua própria percepção do lugar. A segunda ação de vazado-

251 Albuquerque, op. cit., pp. 87-88 res é um exemplo paradigmático desse movimento; nela, o convite para embarcar naquele espaço pressupunha uma ação na duração, pela qual o sujeito se deslocaria ao longo da obra-corredor - seja ele visitante da exposição ou usuário (desavisado) do parque. A concretização de tal experiência exigiria a projeção do corpo do sujeito em deslocamento no "espaço-obra" da passagem.

$O$ ato de atravessar a fronteira é lido pelo artista Yiftah Peled como um ato de performance; porém, nesse caso, não era nem o artista nem o performer o seu protagonista, mas o público, que teria de se reposicionar diante da obra. Além do mais, segundo Peled, na medida em que a passagem de vazadores era controlada por câmeras, "o visitante podia assistir sua própria entrada performática”. ${ }^{252}$ (Neste ponto, é preciso antecipar que durante as negociações com a bienal para acontecer o livre trânsito, o artista acabou instalando uma câmera de segurança acima da obra para "acompanhar" o controle que a fundação estaria fazendo no fluxo de pessoas. A polêmica sobre o acordo de mútua vigilância, que culminou na saída do artista da bienal, será vista mais à frente.)

Diferentemente dos trabalhos abordados no conjunto das "imagens performáticas”, em que o artista se colocava na perspectiva do agente da ação, neste segundo conjunto, e especialmente em vazadores, a obra se dava no ato da passagem desempenhado pelo corpo do sujeito, mediada pelo elemento arquitetônico do corredor.

No entanto, Rubens sabia do risco de a obra passar despercebida pelo público, pois sua oferta não era tão explícita assim... No trecho a seguir, o artista admite que:

[...] somente com uma aproximação curiosa - mesmo sem ter a menor ideia do significado dessa estrutura, as pessoas poderiam acionar uma das portas de vidro, ter acesso ao "corredor" e, num segundo movi-

252 Peled, Yiftah. Interfaces expositivas, Revista do Colóquio de Arte e Pesquisa do PPGA-UFES, ano 3, v. 3. n. 5, dez. 2013, p. 156 
mento (ao cruzar a outra porta), alcançar o lado de dentro ou de fora do edifício. ${ }^{253}$

Tal como exposto em obras anteriormente apresentadas neste estudo, a disponibilidade do sujeito, que o levaria a um "despertar para a obra" de Rubens, foi apontada por Thais Rivitti como questão crucial para a efetividade da ação artística, pressuposta em diversas proposições no conjunto da obra de Mano. Ao depender de uma "disponibilidade imprevisível do público para ocorrer", a obra se coloca neste terreno obscuro entre o artístico e o "não-artístico". O "espaço em ato", assim, desencadeia um tensionamento inclusive do estatuto da arte enquanto obra, acabada e franqueada ao público.

\section{A INSTITUIC̣ÃO..., A CURADORIA E AS NEGOCIAC̣ÕES}

O contexto institucional em que vazadores foi elaborado possui vários aspectos, e envolve desde os precedentes da bienal de 2002, notadamente os percalços que a gestão de Carlos Bratke atravessou em relação às conduções políticas e missões culturais da fundação; passando pela escolha curatorial da $25^{\mathrm{a}}$ edição; pelas relações estabelecidas entre curadoria e artista ao longo do processo de elaboração das obras; até o rompimento dessas relações no momento em que Rubens Mano decide se retirar da exposição.

Para a realização da $25^{\underline{a}}$ Bienal foram necessários quatro longos anos de espera entremeados por uma crise institucional e curatorial (à época, muitas reportagens a destacaram como a maior crise da Fundação Bienal desde sua criação). À gravidade da situação financeira somavam-se as renúncias do presidente do conselho e de cinco de seus membros. A instabilidade também acometeu a condução artística da gestão Carlos Brakthe, que por meses se desentendeu com o então curador Ivo Mesquita, principalmente no que diz respeito ao adiamento da $25^{\underline{a}}$ edição em 1 ano, alegando escassez de verba $e$

253 Mano, op. cit., 2006b, p. 111 problemas de infraestrutura do pavilhão. Mesquita tinha sido indicado pela fundação como responsável pela 25ํㅡㄹ Bienal, que coincidiria com as comemorações de seu cinquentenário em 2001. Entre demissão, readmissão e renúncia final de Mesquita em meados daquele ano, foram meses de instabilidade institucional que puseram em cheque a legitimidade da gestão e a relevância política do evento. A substituição do brasileiro pelo alemão Alfons Hug, anunciada em outubro de 2001, e oficializada em janeiro de 2002, acirrou ainda mais os descontentes do métier artístico nacional, que viam com maus olhos a presença de um curador estrangeiro à frente da edição que marcaria os 50 anos da mostra.

Paralelamente, a gestão Bratke acabou organizando uma mostra comemorativa ainda em 2001, mas restrita ao âmbito nacional (possivelmente devido aos custos reduzidos). A "Bienal dos 50 Anos", como ficou conhecida, também pretendeu explorar a temática da metrópole; porém, como resultado, foi mal recebida pela crítica no geral, e acabou sendo considerada um "fiasco".

Indicado pelo curador e historiador da arte Nelson Aguilar, o alemão Alfons Hug soube aproveitar, ao menos conceitualmente, a vocação da instituição e daquela gestão especificamente (cuja equipe era composta majoritariamente por arquitetos e pessoas afins, trazidos pelo arquiteto-mor Carlos Bratke). Ao propor para a $25^{\underline{a}}$ edição o mote "iconografias metropolitanas”, Hug não teria como não ser bem recebido. Apesar da crise, a repercussão da crítica especializada apontou alguns aspectos positivos na condução curatorial de Hug para a 25를 Bienal: além de decretar o fim dos "núcleos históricos" - pelo qual rompeu com o formato tradicional das edições anteriores, baseado em Veneza, assumindo definitivamente a vocação contemporânea da mostra -, as opções artísticas do curador conseguiram atrair um público recorde em 2002.

\section{A curadoria}

No texto "Iconografias metropolitanas", publicado no catálogo oficial do evento, Alfons Hug abre o tema geral da mostra com a seguinte premissa: 
O tema da 25ํㅗㄹienal de São Paulo, "Iconografias metropolitanas", não se refere apenas à imagem da metrópole na arte contemporânea mas também à maneira pela qual correntes de energia urbana influem nos artistas contemporâneos. Partimos nesse tocante da premissa de que também nos dias atuais, como já há 100 anos nos casos de Paris, Berlim e Moscou, as metrópoles definem substancialmente o perfil da criação artística. E agora as novas megalópoles, que nas últimas décadas cresceram quase que explosivamente na Ásia, África e América Latina, despertam cada vez mais atenção. Nelas transcorrem os grandes dramas urbanos, são testadas novas formas de convívio humano e desenvolvidas novas estratégias de sobrevivência. No laboratório das metrópoles surge, por fim, também a massa crítica que transforma o Zeitgeist (espírito da época) em arte. ${ }^{254}$

Até aqui chama atenção a distância secular que o curador estrangeiro coloca entre a metropolização de São Paulo e das capitais europeias. De alguma forma, mesmo que simbolicamente, o cosmopolitismo da arte moderna brasileira tinha sido uma marca desde pelo menos o movimento antropofágico nas primeiras décadas do século XX, o que contrariara o discurso de Hug sobre a história da cidade.

texto do curador segue com os impasses que acometeriam os artistas no enfrentamento da cidade...

[...] diante do simples tamanho de muitas megacidades, dentre elas a própria São Paulo, coloca-se também a pergunta de como os artistas lidam com o problema da escala. Como a obra de arte concorre com as dimensões metropolitanas? Diante da velocidade e complexidade dos processos urbanos existe o risco de a arte ficar "a reboque" da cidade,

254 Hug, Alfons. Iconografias metropolitanas. $25^{\underline{a} B}$ Bienal de são Paulo - Países. (Catálogo de exposição). São Paulo: Fundação Bienal de São Paulo, 2002, p. 16. ao invés de correr à sua frente e indicar-lhe a direção. Será que a arte é domesticada pela cidade?255

As indagações de Hug soam apaziguadas no momento seguinte, onde o curador muda o tom e de certa forma "desiste" desse embate...

Um número considerável de artistas da presente edição da Bienal ocupou-se intensamente com o tema da cidade e criou obras que se referem diretamente a São Paulo. Mas não se trata, aqui, de arte no espaço público, que, no caso de São Paulo, sempre corre o risco de desaparecer no vórtice do urban sprawl sem chamar a atenção. Faz mais sentido recuar para o espaço protegido do pavilhão da Bienal, que permite uma contemplação das obras, concentrada e sem perturbações. [...] Sob as condições da metrópole, a arte não concorre apenas com a arquitetura, mas também com todas as formas de cacofonia e contaminação visual. ${ }^{256}$

Ao discurso curatorial de Hug reagiu uma das críticas apontadas no artigo sobre a 25를 Bienal, escrito por Rodrigo Moura e Carla Zaccagnini e publicado na revista ArtNexus no período:

Para ser uma exposição dedicada à (metro)polis, lhe falta consciência política, e consciência de seu próprio papel político nesta cidade. A autorreferência que este edifício apresenta, sendo o único e onipresente espaço expositivo para todos os projetos, já é exemplo disso. ${ }^{257}$

As justificativas do curador para restringir a atuação dos artistas ao interior do Pavilhão Ciccillo Matarazzo parecia esbarrar igualmente nas intenções de

255 Ibidem.

257 Moura, Rodrigo e Zaccagnini, Carla. XXV Bienal de São Paulo, ArtNexus, n. 46, 2002, p. 33. 
Mano para a sua participação naquela edição. Antes de mergulhar propriamente no abismo deflagrado entre as duas visões de arte, a pesquisa julgou importante examinar a proposta curatorial mais detidamente.

A princípio, o tema da metrópole era assertivo, não só por conveniência - na convergência com a gestão Bratke e com a memória institucional da bienal em relação à sua vocação para a cidade -, mas também pelas próprias mudanças deflagradas nas grandes capitais ao longo dos anos 1990, que culminaram no crescimento extensivo e desordenado das cidades e mudaram significativamente o modo de vida urbano nelas ensejado. Não à toa, o tema aparecera com frequência no mundo da arte entre os anos 1990 e 2000, a exemplo da própria mostra comemorativa Bienal 50 Anos e do projeto Arte/Cidade (já abordado com detetor, mas que teve uma quarta edição justamente no mesmo ano da bienal de Hug), para ficar apenas em exemplos nacionais

Assim, apesar de não ser um tema original em meio a um vasto referencial de exposições de arte contemporânea pautadas em torno da cidade e da temática urbana, a aposta curatorial de Hug era sem dúvida relevante para a cidade de São Paulo, que se mostrava carente de reflexões sobre si mesma. Afinal, além da pauliceia ter despontado como uma das primeiras megalópoles do mundo, ela tinha conquistado recentemente o pódio das 30 cidades globais, 258 influentes no jogo global das trocas financeiras, informacionais e simbólicas.

Entretanto, a escolha temática acabou se limitando a uma relação distanciada da cidade. Tanto a opção curatorial em restringir a ocupação das obras ao pavilhão (lembrando a indagação de Moura e Zaccagnini, "é sempre a cidade a que deve caber na exposição, e nunca é a exposição que deve ir ao encontro da cidade"?), ${ }^{259}$ como a abordagem iconográfica acerca da questão

258 Sobre a interpretação da cidade de São Paulo como "cidade global", ver Capítulo 3: Interpretação das teorias da cidade mundial, cidade global e cidade pós-moderna referentes a São Paulo. Souza Rosangela Silva Uma investigação sobre as teorias da cidade mundial cidade global, cidade pós-modera sua relação com a cidade de São Paulo. Dissertação (Mestrado em Ceografia Humana) - Faculdade de Filosofia, Letras e Ciências Humanas - FFLCH-USP. São Paulo, 2008. 259 Moura e Zaccagnini, op. cit., p. 32. metropolitana circunscreviam a experiência da cidade à uma visada "descolada", por vezes ilustrativa, distante das dinâmicas reais da vida urbana, de seus conflitos e contradições. O interesse curatorial acabou reduzido à uma iconografia da cidade, à sua aparência e superfície, em contraposição ao que seria estrutural, desperdiçando a oportunidade de pensar a cidade na prática.

Tal fato poderia explicar em parte a grande incidência de fotografias e vídeos na mostra. Isso não significa em absoluto a redução do interesse desses trabalhos, mas demarca a perspectiva curatorial de Hug por uma abordagem mais "institucional", numa distância suficientemente protegida, deixando escapar a oportunidade de desafiar o embate direto com a cidade. Dentre esses trabalhos mais documentais e imagéticos, que pontuaram as transformações urbanas das últimas décadas, destaca-se a série de fotografias do alemão Michael Wesely, Potsdamer Platz, realizada entre 1997 e 1999 em Berlim, que registrou a transformação na paisagem urbana daquele lugar. A cidade alemã foi marcada no período por um intenso processo de reurbanização, que assentou o paradigma da reconversão urbana de bairros degradados no modelo do planejamento estratégico para alavancar um novo ciclo de vida (econômico e cultural) para a cidade. ${ }^{260}$

Neste caso, a dialética entre espaço e imagem de espaço, proposta por Laymert nas leituras sobre detetor de ausências, poderia ajudar a compreender a oposição entre a imersão direta na cidade (o espaço) e a iconografia dessa (imagem do espaço). Se colocarmos em confronto as duas situações expositivas expressas entre os pontos de vista do artista, em 1994, e do curador, em 2002, é possível inferir que: no caso do Arte/Cidadez, a situação urbana gerou uma imagem de cidade (contrafotografia) construída no e a partir do próprio tecido

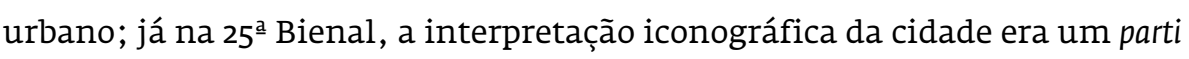
pris curatorial, e restringia o acontecimento das obras ao recinto expográfico do pavilhão, tendendo portanto a uma imagem sobre a imagem da cidade.

260 Sobre o assunto, cf. Arantes, Otília B. F. Berlime e Barcelona: duas imagens estratégicas. São Paulo: Annablume, 2012. 
O segmento da $25^{\underline{a}}$ Bienal que mais expressou o conceito de "iconografias metropolitanas" foi o Núcleo Cidades. Para este, Hug elegeu 11 metrópoles do globo - privilegiando, de modo geral, uma distribuição geográfica que incluísse o sul geopolítico ${ }^{261}$-, e propôs uma cidade utópica. Para cada uma das cidades globais (a saber, São Paulo, Istambul, Nova York, Pequim, Caracas, Londres, Berlim, Moscou, Tóquio, Johannesburgo e Sydney) foi designado um curador, o qual escolheu cinco artistas para o seu conjunto, sem que houvesse necessariamente uma correspondência com suas nacionalidades. Para a $12^{\underline{a}}$ cidade, Hug se encarregou sozinho de selecionar 12 artistas de diferentes origens do mundo, a qual nomeou de "uma proposta estética para o novo milênio".

Aos olhos de Zaccagnini e Moura, o conjunto das cidades "reais" estabelecia pouca relação entre elas; além disso, sua justificativa de incluir o "sul" adquirira pouca musculatura ao reduzir-se apenas a três autênticos exemplares do que poderia representar a periferia do capital. Tampouco a museografia favorecia uma aproximação entre as metrópoles: a estrutura da montagem era labiríntica, composta de salas muito ensimesmadas (cubos brancos e pretos - estes em decorrência da forte presença de vídeos) e os discursos eram por demais compartimentados.

Do ponto de vista do artista, vazadores pretendeu estabelecer uma posição crítica diante de vários papéis desenhados dentro do circuito da arte contemporânea. Anos mais tarde, eles foram postos em evidência pelo artista em seu texto "um lugar dentro do outro", publicado em 2006:

[a proposta] procurou abordar implicações econômicas e sociopolíticas que permeiam as grandes mostras (incidindo sobre as expectativas e

261 No texto de apresentação para o catálogo, o curador explica suas escolhas metropolitanas:

"Embora a escolha das 11 metrópoles tenha sido necessariamente subjetiva, ela reivindica uma certa

plausibilidade no quadro da concepão a os critérios foram o potenciartístico da cidade sua'massa crítica' a lado de uma distribuiça g g a geogŕfica geoultura que consico de adequadamente o Hemisfério Sul e outras regiões extraeuropeias". Hug, op.cit, p. 17 responsabilidades normalmente lançadas por uma instituição cultural) e questionar nosso papel de agentes no interior do corpo social. [...] se o espaço controlado do museu, ou da instituição, costumeiramente representa um espaço de certezas, vazadores procurou sinalizar uma pequena dose de instabilidade. ${ }^{262}$

Seria preciso, então, atravessar as negociações entre o artista e a instituição ao longo do processo para entender mais precisamente em que medida a obra fazia a crítica àquela e, por extensão, às regras do jogo artístico contemporâneo.

\section{As negociações}

A execução do vazador do térreo envolveu um longo processo que se iniciou em novembro de $2001^{263}$ e terminou em 17 de maio de 2002, quando Rubens se desliga oficialmente da $25^{\underline{a}}$ Bienal. Na reportagem de Armando Antenore, publicada no jornal Folha de S.Paulo uma semana após a saída do artista, o jornalista noticiou o fato e enumerou as razões do desligamento:

Desde sua proposição, a obra começou a evidenciar que essa intervenção quase imperceptível perturbava a ordem estabelecida, e expunha os limites estreitos em que se dá a circulação dos humanos na sociedade contemporânea. Com efeito, antes mesmo de ser instalada a obra, o "vazamento" do exterior para o interior, ou vice-versa, colocava de imediato efeitos sociais, políticos e econômicos que a obra causaria, ao permitir que as pessoas pudessem entrar e sair livremente do prédio da Bienal, sem nenhuma espécie de controle, sem pagar ingresso, em suma, sem dever explicações de nenhuma ordem. ${ }^{264}$

262 Mano, op. cit., 2006b, p. 111

263 Data que consta no projeto de Rubens encaminhado à curadoria, cujo documento original está no Arquivo Wanda Svevo da Fundação Bienal.

264 Antenore, Armando. Sob protesto, Rubens Mano deixa a Bienal de São Paulo, Folha de S. Paulo, 
Do ponto de vista da Fundação Bienal, mais do que a preocupação patrimonial sobre a intervenção na arquitetura do pavilhão, a segunda ação de vaza dores expunha a instituição a uma situação de vulnerabilidade, ao franquear o acesso para o interior do edifício, sem qualquer intermediação - seja ela a compra de um ingresso, uma catraca ou qualquer outro filtro de segurança na entrada. A vulnerabilidade alegada por parte da fundação foi interpretada por muitos como uma preocupação de ordem estritamente financeira, em que o dinheiro aparecia como pré-requisito para o acesso à arte ali exposta.

Do ponto de vista do artista, a ação cogitava "uma espécie de desorientação para os usuários do Parque Ibirapuera e da Bienal, propondo-lhes uma relação direta com um espaço-simulacro - através da violação de suas próprias condições espaciais". ${ }^{265} \mathrm{E}$, como consequência, implicava o enfrentamento real da cidade por parte da mostra, indo de encontro justamente ao tema proposto pela curadoria. Além disso, na medida em que a passagem era transparente e não sinalizada, a obra apontava para uma correspondência possível entre o dentro e o fora do pavilhão modernista, fazendo-se materializar as intenções presentes no partido arquitetônico de Niemeyer e convocando a Fundação Bienal a se pensar enquanto instituição cultural na cidade e da cidade.

Segundo consta na carta de desligamento do artista, "por se tratar de um projeto 'transgressor' - segundo as palavras do presidente da Bienal -, a produção do projeto, mesmo com a aprovação da curadoria, somente pode ser iniciada após o consentimento da diretoria". ${ }^{266} \mathrm{~A}$ aprovação final da diretoria da bienal condicionou a realização da obra à contratação de um segurança alocado ao lado da obra para monitorar a circulação de pessoas através do corredor. Entretanto, conforme relato do artista publicado no dossiê organizado por Fernando Olivia sobre vazadores, e publicado na revista Tropico, a aceitação do segurança por parte do artista estabelecia que "em hipótese alguma a

Illustrada, 24 maio 2002.

265 Mano, op. cit., 2006b, p. 103.

266 Carta do artista endereçada aos curadores da $25^{\mathrm{a}}$ Bienal, cujo original consta do Arquivo Wanda Svevo. atuação desse funcionário da fundação poderia inibir o livre deslocamento do público", 267 a não ser em casos extremos de tumulto.

Diante dessa situação, Rubens passou a considerar a importância de monitorar o controle institucional, uma espécie de vigília sobre a vigília. Para tanto, contratou uma pessoa para acompanhar as imagens transmitidas por uma câmera de segurança instalada pelo artista sobre a passagem. ${ }^{268} \mathrm{O}$ contratado trabalharia a partir de um "posto" instalado no próprio espaço expositivo do segundo andar do pavilhão, no qual o artista dispôs uma mesa, duas cadeiras, um monitor de vídeo e um gravador de VHS

A passagem que permitia o acesso gratuito e "clandestino" à exposição em poucos dias atraiu a atenção dos meios de comunicação e levou a direção da Fundação Bienal a regular o fluxo de visitantes a um número determinado por hora. Segundo consta nos relatórios de ocorrências da equipe de segurança da fundação, arquivados na documentação sobre a $25^{\underline{a}}$ Bienal do Arquivo Wanda Svevo, a partir do dia 2 de abril (ou seja, 10 dias após a abertura oficial da exposição) teve início um controle diário no fluxo de pessoas que passavam pela obra. Ao analisar mais detidamente tais relatórios, durante a primeira semana houve uma tendência a permitir a passagem de até 10 pessoas a cada intervalo de tempo em que a porta ficava "aberta"; em geral, dividiu-se o acesso à obra entre três intervalos de tempo ao longo do dia; no total, uma média de 30 pessoas passaram pelo vazador por dia durante a primeira semana. A partir do relatório do dia 9 de abril, nota-se que o controle passa a ser mais restrito, liberando apenas 5 pessoas por intervalo.

Apesar das negociações até aqui estabelecidas, as tensões entre instituição e artista seguiam. Os organizadores da Bienal continuaram pressionando

267 Mano, op. cit., 2006b, p. 111.

268 Em carta de 25 de março, dois dias após a abertura oficial da mostra, a gerência de eventos da bienal comunicou ̀̀ equipe de segurança a existência de uma pessoa uniformizada de segurança no segundo andar que fazia"parte da obra". Comuniçção interna assinada pela Gerência de Eventos, nas

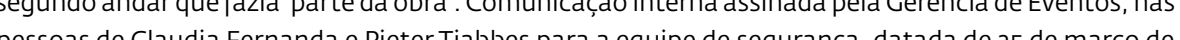
pessoas de Claudia Fernanda e Pieter Tjabbes para a equipe de segurança, datada de 25 de março de 2002, cujo original consta no Arquivo Wanda Svevo. 
o artista no sentido de estabelecer novas regras restritivas ao acesso da obra quanto ao limite de pessoas, ainda receosos da perda em arrecadação que a entrada por vazadores representava. Pois, à medida que a obra começava a ser descoberta, aumentava a possibilidade de se tornar um ponto de perda econômica. Porém, nos relatórios da segurança, o número de pessoas que vinham utilizando o trabalho como entrada para a mostra era inexpressivo (50 por dia).

A saída de Rubens da exposição foi precipitada por uma série de ocorrências no final do mês de abril. Por mais de uma tarde o artista permaneceu no espaço e retirou o pino da porta que a travava, questionando as orientações institucionais de conduta da obra. Segundo consta dos relatórios de ocorrência da segurança, entre os dias 3 e 16 de maio a intervenção foi mantida fechada por motivos técnicos, tornando-se a gota d'água para a saída de Mano da exposição. No dia 17 de maio de 2002, o artista comunicou oficialmente o rompimento com a fundação e formalizou a retirada da obra por meio de uma carta endereçada aos curadores e à gerência de eventos, em nome de Peter Tjabbes.

Uma semana depois, o departamento jurídico da Fundação Bienal colocou o seguinte aviso na obra: "obra temporariamente bloqueada em decorrência da retirada pelo artista do eixo pivotante da porta". ${ }^{269} \mathrm{O}$ aviso certamente encobria os reais motivos do não funcionamento da obra.

Do ponto de vista das negociações, o que se evidenciou foi uma conduta da direção da Bienal sobreposta às atribuições da curadoria, esta ofuscada desde o início pelas preocupações do setor da engenharia quanto ao resguardo patrimonial do edifício (da primeira parte de vazadores, não realizada) e do setor financeiro quanto às perdas econômicas da bilheteria do evento (na segunda parte de vazadores, no térreo).

269 Comunicado interno da assessoria jurídica datado de 23 de maio de 2002 , cujo original consta do Arquivo Wanda Svevo.

\section{ÊXITO OU FRACASSO?}

Os desdobramentos apontados pela crítica após a interrupção precoce da obra compõem ainda um outro capítulo da história de vazadores. Teria a obra fracassado? Ou seu incômodo por parte da instituição já era um sinal de que teria alcançado seus objetivos? Ela foi "destruída” pela fundação ou tinha um prazo para se dissolver?

Entre os críticos que se manifestaram sobre a polêmica, Laymert se disse surpreso com a quase não realização da obra por conta da interferência da Bienal:

Se houve uma ousadia, muito discreta, de Rubens Mano em fazer seu trabalho, por outro lado a proibição mostrou uma série de limites da própria instituição. Ficou mais claro que há fronteiras entre o que é e o que não é permitido fazer hoje. Hoje em dia, na arte contemporânea, existe a suposta crença de que se pode fazer tudo, e no entanto uma intervenção que se colocava ali de modo silencioso foi rapidamente neutralizada. Nem a crítica explorou nem a imprensa se colocou de modo consequente em relação ao impasse, e isso para mim também é ilustrativo deste nosso momento. ${ }^{270}$

Na opinião de Lisette Lagnado,

o trabalho já funcionou, mesmo que interditado. Acredito que o boca a boca fez a sua parte. Eu diria que este rumor que causou foi extremamente interessante. Não vimos filas enormes para entrar por aquela passagem, não houve tumulto. $\mathrm{O}$ trabalho foi abortado antes mesmo de acontecer qualquer "tumulto" esperado. ${ }^{27}$

270 Laymert Garcia dos Santos apud Oliva, op cit.

271 Lisette Lagnado apud ibidem. 
que permitem sua circulação e as relações de poder que representam ditas instituições: em um palavra, tudo aquilo que esconde o discurso estético tradicional. ${ }^{273}$

teria que terminar, se completar, no momento em que fosse descoberto. Se o artista propôs aquilo anonimamente, aquela entrada teria de conter algo de uma descoberta. À medida que a “descoberta” se tornou uma coisa propalada, boca a boca ou por qualquer outra maneira, portanto se tornando um lugar de penetração de "outsiders" na Bienal, o trabalho se completou. O efeito foi obtido, e ele teria que terminar. ${ }^{272}$

Desde o início, o desafio imposto pela proposição de Mano exigia um comprometimento de várias partes envolvidas no circuito cultural para o pleno funcionamento da obra: do artista, em não expor o trabalho para a cobertura jornalística do evento; da imprensa, em não mencioná-lo; do curador, em não divulgá-lo; da instituição, em permitir o vazamento. Ao longo das semanas, as interferências da Fundação Bienal sobre a obra do artista acabaram limitando a experiência perceptiva que o público vivenciaria diante de vazadores (quer ela durasse o período todo da mostra ou não), e colocaram em cheque a vocação da própria fundação quanto às suas prioridades na condução política da instituição no que diz respeito ao fomento à arte contemporânea.

A problemática instaurada em vazadores pode ser posta em analogia a um outro fato ocorrido na história da arte contemporânea, em meados dos anos 1980, que envolveu a obra de Richard Serra, Tilted Arc. No artigo de Douglas Crimp, "A redefinição da especificidade espacial", em torno da polêmica sobre a obra de Serra, o crítico de arte apontou um aspecto importante daquele tipo de prática artística que produzia uma crítica materialista sobre os fundamentos institucionais da arte:

[...] tais práticas têm como fim revelar as condições materiais da obra de arte, seus modos de produção e recepção, os apoios institucionais

272 Celso Favaretto apud ibidem.
Na perspectiva crítica apontada por Crimp, a ideia de "fracasso" não se aplicaria nem em Mano nem em Serra, uma vez que a obra, por menos tempo que tenha durado, já provocou um pensamento e uma reflexão sobre aquele espaço em que se instalou, seja este eminentemente público ou localizado na fronteira entre o público e o privado. Em vazadores, especificamente, os limites institucionais do que representa a Fundação Bienal para a arte brasileira (e por que não para a arte internacional) foram colocados em questão, e incluíram desde sua realidade física, arquitetônica e patrimonial, passando pelos seus modos de exposição e fruição das obras, até suas relações de poder implicadas tanto no que representa para a cidade como no jogo global da mundialização da arte.
273 "Tales prácticas tienen como fin revelar las condiciones materiales de la obra de arte, su modo de producción y recepción, los apoyos institucionales que permiten su circulación y las relaciones de poder que representan dichas instituciones: en una palabra, todo aquello que esconde el discurso estético tradicional". Crimp. Douglas. La redefinición de la especificidad espacial. Blanco et. al. (orgs.), op. cit., p. 147 


\section{O PARADIGMA DA CRÍTICA INSTITUCIONAL}

Num exaustivo levantamento bibliográfico de tudo o que já foi escrito a respeito de vazadores, veremos que boa parte dos textos posicionam a crítica institucional como discussão central da obra. Contudo, é preciso elucidar que o que se denominou como práticas artísticas que endereçavam uma crítica à instituição não se resume a um ataque direcionado exclusivamente ao objeto "instituição". A fim de precisar suas implicações nas leituras sobre a obra de Mano para a 25ํㅗㄹ Bienal, a pesquisa recorrerá à definição de crítica institucional elaborada pela artista Andrea Fraser no texto "O que é crítica institucional", cuja tradução foi publicada pela revista Concinnitas, em 2014:

[...] a Crítica Institucional só pode ser definida por sua metodologia de especificidade do site criticamente reflexiva [critically reflexive site-specificity]. Enquanto tal, ela pode distinguir-se em primeiro lugar de práticas site-specific que lidam basicamente com o aspecto físico, formal ou arquitetônico de lugares e espaços. A Crítica Institucional ocupa-se de sites acima de tudo como sites sociais, conjuntos estruturados de relações que são fundamentalmente relações sociais. [...] um site é um campo social dessas relações. Dizer que a Crítica Institucional ocupase de tais sites de forma reflexiva é especificar que, entre as relaçooes que definem qualquer site estão tanto nossas relações ao site quanto as condições sociais dessas relações. Dizer que esse engajamento reflexivo é crítico é dizer que ele não visa afirmar, expandir ou reforçar o site ou nossa relação com este, mas problematizá-lo e mudá-lo.

Na medida em que um site é compreendido como um conjunto de relações, a Crítica Institucional visa transformar não apenas as manifestações substantivas, visíveis dessas relações, mas sua estrutura, e em particular o que é hierárquico nessa estrutura e as formas de poder e dominação, de violência simbólica e material, produzidas por essas hierarquias. Isso é o que distingue a Crítica Institucional de práticas contra-hegemônicas que visam representar ou criar novos espaços para posições excluídas ou subalternas. É também o que distingue a Crítica Institucional de práticas site-specific que propõem criar novas relações sem engajar-se numa crítica específica e explícita das relações existentes nesses sites. ${ }^{274}$

No excerto acima, Fraser deixa claro que a crítica institucional, tal como as práticas contra-hegemônicas e aquelas site-oriented têm uma raiz semelhante, qual seja a de sua natureza contextual, cujo caráter é necessariamente contrário a uma certa autonomia da arte (igualmente visto nos escritos de Solà-Morales e Lippard, citados anteriormente). Porém, a autora faz questão de distinguir essas práticas contextuais surgidas entre os anos 1960 e 1970 entre si, uma vez que cada uma delas teria como estratégia um tipo de abordagem, seja em defesa das minorias, no primeiro caso, seja como tensionamento físico e arquitetônico, no segundo. De certa forma, do ponto de vista de Fraser, a crítica institucional entende o site como um sistema complexo estruturado a partir de aspectos físicos, políticos e sobretudo sociais, ao qual nos relacionamos criticamente. Como prática política, ela é reflexiva no sentido de suas "intenções transformadoras [...] visam, sobretudo, formas de dominação operando em seu campo de trabalho imediato". ${ }^{275}$ Ou seja, o problema não é a instituição como objeto, mas o que ela representa como relações sociais e de poder, como códigos de usos e hierarquias entre o lugar da arte e seus públicos, que em última instância são percebidos como "homologias" estruturais da sociedade contemporânea.

Ao resgatar o histórico do projeto para vazadores e seus desdobramentos na execução da intervenção no pavilhão, a pesquisa buscou identificar as diferentes camadas que orbitam a concepção da obra - desde a arquitetura e seus

274 Fraser, Andrea. O que é crítica institucional, Concinnitas, ano 15, vol. 2, n. 24, dez. 2014. Disponível em: <www.e-publicacoes. uerj.br/index.php/concinnitas/article/download/1873//13645>. Acesso em 5 out. 2017

275 Ibidem. 
constructos modernos, a memória do lugar, passando pelo sujeito enquanto protagonista do atravessamento, até os usos e códigos espaciais institucionais postos em questão. A partir disso, percebeu-se que a ação endereçada ao edifício da bienal não se restringe à generalização que se fez da crítica institucional; suas potencialidades se estruturam na percepção de um contexto que sobrepõe vários extratos, arquitetônico e patrimonial, espacial e temporal, artístico e institucional, sobre os quais o artista elabora suas ações.

Da mesma forma, uma visada institucional sobre vazadores requer ponderações quanto às especificidades do contexto hegemônico do norte nos anos 1970, figurado na produção norte-americana e europeia, e do que aconteceu no Brasil e na América Latina em geral. De acordo com o historiador Emerson Dionísio de Oliveira, em seus estudos sobre as relações entre museu e arte contemporânea:

é prematuro fixar o rótulo da "crítica institucional" para uma produção que estivera ligada a contextos políticos e institucionais distintos daqueles operados na Europa e nos Estados Unidos. No caso da América Latina, é estimulante especular que os artistas estão prontos a expressar sua inquietude diante de tais instituições, mas, ao mesmo tempo, dispostos a conviver com ela..$^{276}$

No contexto brasileiro, o convívio com a instituição pode ser interpretado como decorrente da sua pouca tradição como protagonista na formação de público e como facilitadora de práticas artísticas no circuito local durante os anos 1970. Portanto, não era o caso de negá-las por completo, mas de fazer com que elas se renovassem ao atuar a partir delas.

Considerando o contexto em que surgiu a noção da crítica institucional, nos anos 1970, no panorama específico da produção paulista, surge uma curio-

276 Oliveira, Emerson Dionísio de. Museu-obra: o museu como problema da arte contemporânea, Museologia \& Interdisciplinaridade, vol. 5, n. 10, jul.-dez. 2016, p. 163. sa comparação que a tese se propõe a estabelecer entre o "abrir" de vazadores e o "fechar" de X-Caleria. Em 6 de julho de 1979, o grupo 3Nós3 (cujos integrantes eram jovens oriundos do curso de artes da ECA-USP) realizou uma intervenção intitulada Operação X-Caleria (figs. 24 a 26), por meio da qual lacraram portas de várias galerias paulistanas com adesivos em " $X$ " e afixaram sobre elas folhas de papel com a frase "o que está dentro fica, o que está fora se expande".

$\mathrm{Na}$ ação do 3Nós3, o afrontamento a esses recintos privados era uma estratégia para se criticar as instituições vigentes no mercado local, que ainda se limitavam a expor exemplares do modernismo. Ironicamente, a frase adesivada nas portas das galerias decretava uma incomunicabilidade entre os dois mundos, o de dentro e o de fora, e os colocava em perspectivas opostas (de introversão e de expansão). Do que se pode depreender que: tudo o que envolvia a arte exposta em galerias se restringia a poucos interlocutores; enquanto que tudo o que se produzia fora desse perímetro institucional era aberto e se expandia, comunicativamente. Num ato transgressivo, o " $\mathrm{X}$ " como sinal de negação demarcava a inexistência de trânsito entre os dois ambientes. Diferentemente da ação do 3Nós3, em vazadores a percepção sobre a falta de comunicação entre os dois mundos (o da arte e o da cidade) não foi operacionalizada como negatividade, mas, ao contrário, pela positivação de um livre trânsito mútuo entre os dois lados, instaurando um espaço fluido que anulava temporariamente a fronteira.

Em X-Galeria, o contexto de repressão e censura dos anos 1970 foi determinante para o modo como a ação foi feita sorrateiramente na calada da noite (uma espécie de "anarquismo construtivo", na expressão do próprio grupo); mas, para ela se alastrar e tornar-se pública, o grupo contava estrategicamente com a cobertura do jornalismo impresso que a noticiava no dia seguinte. ${ }^{277}$ No caso de vazadores, ao revés, a ação foi pensada de dentro

277 À reportagem jornalistica publicada na manhã seguinte noticiando a intervenção, seguiram-se vários artigos de jornais pelos quais críticos e galeristas manifestavam suas indignaçōees. No Jornal da Tarde do dia 4 de jutho de 1979, a manchete estampava a frase" $O$ ataque às galerias. Os atacados se refazem da surpresa e contra-atacam"; a edição trouxe depoimentos de vários galeristas. Artur Camargo, da Cos- 

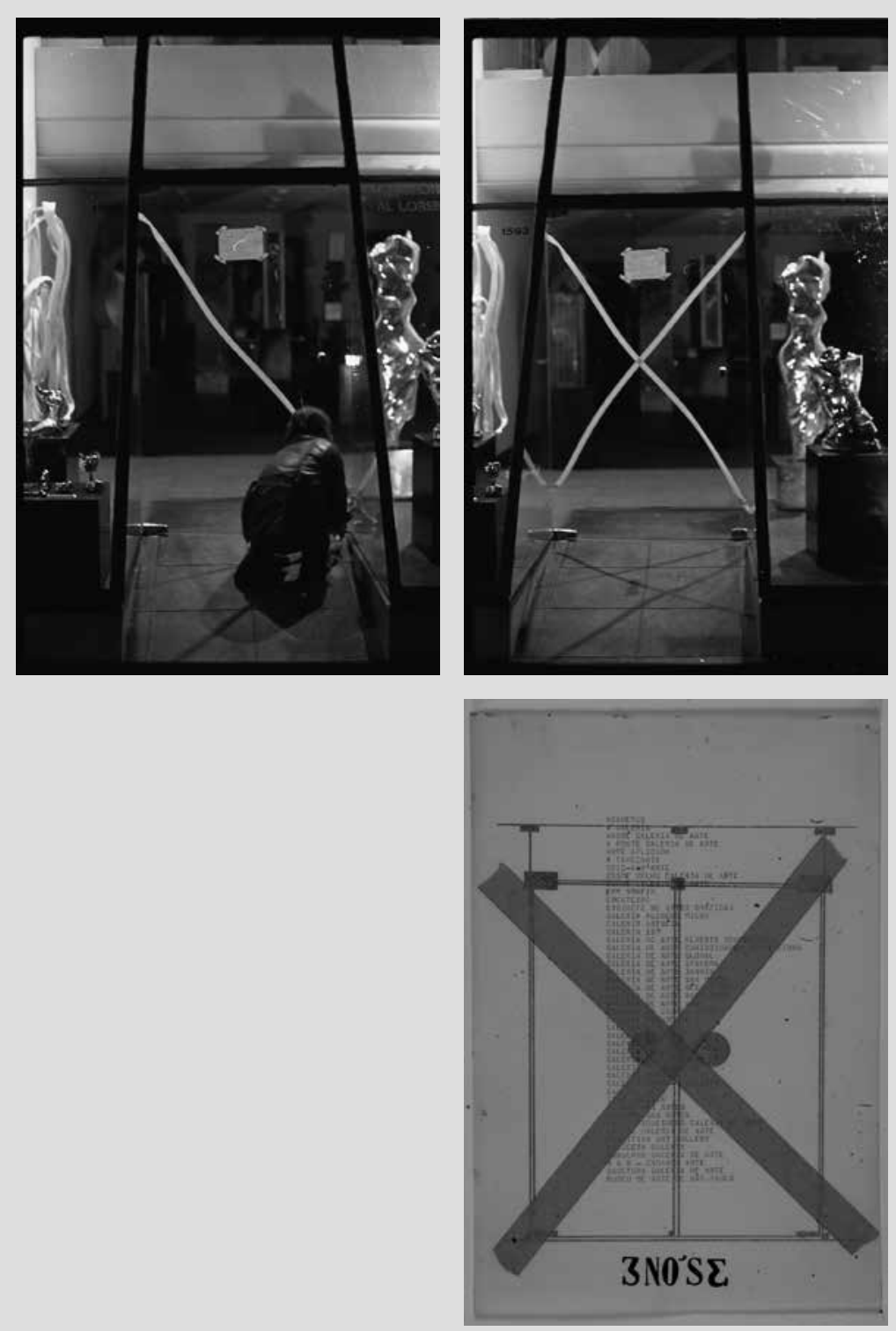

do espaço institucional e com o consentimento da bienal; porém, precisou contar com o silêncio de todos, artista, bienal e assessoria de imprensa, para se efetivar.

A comunicação entre os circuitos (de arte e do mundo real) não era um problema exclusivo da arte produzida a partir de São Paulo. Outro caso exemplar, ao qual Rubens também se reporta para pensar a sua prática artística, é a série Inserções em circuitos ideológicos, de Cildo Meireles, iniciada em 1970 com "Projeto Coca-Cola", durante o período da ditadura militar. O projeto consistiu em inscrever nas garrafas de vidro, utilizadas à época, frases com opiniões críticas e devolvê-las à circulação. Na ausência de liberdade de imprensa e de opinião pública, Cildo percebeu argutamente que o único espaço aberto de livre circulação era o espaço das mercadorias. ${ }^{278}$ Para tanto, Cildo empregou uma estratégia silenciosa (analogamente às ações de Rubens, décadas mais tarde) ao utilizar o mesmo material que imprimia as marcas do refrigerante sobre os vasilhames - uma tinta branca industrial vitrificada, pela qual as garrafas alteradas se diluíam entre as produzidas oficialmente pelo fabricante. No artigo publicado na revista Malasartes, em 1975. Cildo a considera uma inserção mimética, "pois a tinta sendo branca, só aparece quando a garrafa torna a ser cheia”, 279 e é devolvida novamente ao circuito do consumo.

Segundo a crítica de arte Thais Rivitti, o projeto de Cildo

sugere um extravasamento do circuito de arte. [...] inserida no fluxo da circulação de vasilhames, a obra de arte poderia romper com o circuito já conhecido da arte. Ao mesmo tempo mostra uma insufi-

\section{FIGS. 24-25}

3Nós3. Operação X-Galeria, 1979 Intervenção com fita adesiva e texto mimeografado sobre a fachada de galerias em São Paulo
FIG. 26

3Nós3. Operação X-Galeria, 1979

Lista de galerias que foram alvo da intervenção do grupo
meVelho, chegou a pensar que era"uma nova versão da pichação, nacional, porque a outra é importada e, por sinal, chegou com um atraso de pelo menos sete anos". Raquel Arnaud declarou que não merecia importância "por não saber exatamente do que reclamam os artistas". Ainda na mesma edição, o texto de Jacob Klintowitz destacava a frase "Escândalos, violências. Que artistas são esses?"

278 Cymbalista, Renato. Sobre espaços públicos impossíveis. Mazzucchelli, Kiki; Cymbalista, Renato; Nicolau, Ricardo (orgs.). Marcelo Cidade: empena cega. São Paulo: Cobogó, 2016, p. 66.

279 Meireles, Cildo. Quem se desloca recebe quem pede tem preferência, Malasartes, n. 1, set.-nov. 1975, p. 15. 
ciência e aponta para um desejo, ou mesmo uma necessidade, de se misturar no caótico fluxo urbano. 280

Para Rivitti, a partir disso, a obra de Cildo trazia uma posição implícita de que o espaço institucional é inadequado, ou ao menos insuficiente, para a ação ou a operação pretendida pela obra de arte. Nesse sentido, segundo a crítica,

a formalização de um trabalho como Inserções em circuitos ideológicos: projeto Coca-Cola já não ocorre de acordo com padrões da estética tradicional, mas em função de uma almejada problematização de uma posição em relação ao sistema das artes e seus componentes: o público, a instituição, o artista. A obra não se instala comodamente no museu, mas invoca a ampliação de seu trânsito social. ${ }^{28}$

Ao sugerir a possibilidade de introduzir a obra no circuito das mercadorias comuns, sem rejeitar sua aparição dentro do museu, a obra reivindica uma outra existência, a do lado de fora da instituição. Tanto a problematização do circuito, apontada por Rivitti nas instâncias do público, da instituição e do artista, quanto a vontade da obra existir simultaneamente nos dois mundos reaparecem em Mano, materializadas no atravessamento de vazadores, à medida que este instaura um espaço "entre" ("in-between"), dissolvido pela fluidez do corredor.

De par com as considerações do historiador Dionísio, é a partir da instituição, de dentro dela, que ambos os artistas Cildo e Rubens buscaram instaurar o trabalho. Nenhuma das proposições se coloca negativamente em relação à instituição; pelo contrário, buscam amplificar seus alcances e seu diálogos com o público na expansão do circuito, seja no fluxo das mercadorias propriamente ditas, no exemplo de Cildo, seja no fluxo de

280 Rivitti, Thais. Uma obra para museu, ARS, n. 13, 2010, pp. 152-153.

281 Ibidem, p. 153. pessoas (e suas percepçoes sobre a produção do espaço) e da arte na cidade, no caso de Mano.

Nesta mesma direção, durante o já citado encontro "Tropico na Pinacoteca", realizado no ano de vazadores, em torno do tema É possível hoje uma crítica institucional?, Lisette Lagnado adicionou um novo aspecto ao debate, que singularizaria o trabalho de Rubens do ponto de vista da crítica institucional:

O que me parece historicamente novo [...] é que há uma apropriação do lugar da instituição como local potencial para a crítica. Não necessariamente com a conivência da instituição, mas de dentro dela. À maneira das listras de Daniel Buren: este usa questões formais da história da arte, como a repetição, a cor e a linha. O que é interessante na obra de Rubens Mano é que ela comenta o "dentro" do espaço da arte, com seus elementos constitutivos. ${ }^{282}$

Assim, Mano estaria muito mais próximo de Cildo do que de Buren, uma vez que comenta o dentro da instituição de arte com os seus próprios elementos constitutivos. Ao eleger listras e cores como elementos básicos para realizar suas intervenções entre o espaço do museu e o espaço da rua, Buren ainda recorre a aspectos formais próprios à linguagem da arte. Nos exemplos de Cildo e Mano, ambos os artistas trabalham a partir da natureza do lugar mesmo onde atuam ao imitar seus elementos constitutivos (extra-artísticos): no primeiro caso, a tinta vitrificada da garrafa utilizada pela indústria de refrigerante, e, no segundo, a estrutura vítrea de vedamento da fachada do pavilhão.

O depoimento de Mano neste mesmo debate na Pinacoteca também dá pistas de como o artista enxerga as mudanças ocorridas na perspectiva da crítica institucional a partir dos anos 1990, derivada de uma prática contextualista dos anos 1960:

282 Lisette Lagnado apud Oliva, op. cit. 
Boa parte da produção contemporânea vem relativizando o conceito de site-specific, informando sobre a importância de um espaço crítico para discutir as instituições, redefinindo nossa ideia de lugar ou anunciando de que maneira proposições estéticas, questões políticas e socioeconômicas precisam ser igualmente consideradas. ${ }^{283}$

Neste caso, o discurso do artista parece referendar mais precisamente a crítica que se fez em relação à poética do site-specificity, que depois do episódio de Serra em meados dos anos 1980, soava enrijecida e limitada ao problema da dimensão física do lugar e de sua intransponibilidade. De todo modo, o debate sobre a crítica institucional nos ajuda a entender o alcance de vazadores: a obra não apenas constrói uma perspectiva crítica em relação ao papel da Bienal para a arte e para a cidade, no momento em que a instituição completava 50 anos, como também põe em evidência as relações intrínsecas entre o artista, a instituição e seus públicos, em suas dimensões estéticas, sociais e políticas.

\section{ARTE PÚBLICA?}

O debate em torno de vazadores também envolveu uma análise a partir da reformulação de uma ideia de arte pública, atualizada entre os anos 1990 e 2000 em comparação aos anos 1970. Coincidentemente, um dos integrantes do grupo 3Nós3, Hudinilson Jr., esteve presente no encontro da Pinacoteca promovido pela revista Tropico, e chegou a se manifestar sobre o que significava atuar na cidade naqueles anos de chumbo: "Nossa visão de arte pública era essencialmente política. Tomamos por atitude a invasão. Éramos obrigados a fazer quase tudo na surdina, e mesmo assim tivemos muitos problemas". ${ }^{284}$

283 Rubens Mano apud Oliva, op. cit.

284 Hudinilson Jr. apud Oliva, op. cit.
O depoimento de Hudinilson Jr. releva um tipo de entendimento sobre o significado político da arte, especialmente daquela endereçada ao espaço público, mais próximo de negação do que de afirmação. Naqueles anos de regime ditatorial, boa parte dos artistas que se colocavam num enfrentamento mais direto do sistema artístico vigente acabou incorporando em suas ações um viés político: elas aconteciam nas brechas do sistema, buscavam novos lugares para a arte (principalmente fora do circuito emergente das galerias), e eram operadas de modo sorrateiro, evitando-se a repressão policial. Desse modo, o enfrentamento político do regime se beneficiava de seu extravasamento pela arte; no caso das ações do grupo 3Nós3, elas logo se dissolviam no fluxo da cidade, deixando rastros apenas no noticiário jornalístico.

Já em Rubens, e em tantos outros artistas que produzem a partir da década de 1990, o aspecto político da obra não reside necessária e exclusivamente na política, mas na crítica que se faz dentro e a partir do circuito cultural artístico legitimado - no exemplo de vazadores, representado pela instituição. Ou seja, muitas vezes o aspecto político do trabalho não se apresenta literalmente como um discurso crítico sobre o sistema, mas como uma perspectiva crítica do próprio fazer, expor, fruir e circular o trabalho de arte contemporâneo,

Por outro lado, é recorrente uma leitura sobre o aspecto político da arte pública do ponto de vista de sua capacidade de romper com o status quo e produzir um ruído no cotidiano. É o que Favaretto, por exemplo, identifica como uma grande mudança dos anos 1970 para os anos 1990/2000. Segundo ele, a diferença entre os períodos é que no caso de Hudinilson Jr. as intervenções eram desviantes do circuito; já as de hoje teriam mais estabilidade:

Aquele momento de exceção era propício no Brasil para se explorar ações como essa (do $3 \mathrm{Nós} 3$ ), não regulamentadas, causando um efeito de estranheza que produzia resultados. Hoje estes efeitos não são mais visíveis. Então se cria alguma coisa, como a obra de Rubens Mano na Bienal, para gerar um determinado comportamento, que é regrado - 
mas que é desregrado em relação à hipernormatividade. Ou seja, ele é organizado, constituído e propõe um comportamento, mas que não é anárquico nem visa explorar qualquer espécie de êxtase. ${ }^{285}$

O que Favaretto chamou de "hipernormatividade", aqui é interpretado como uma ação "de dentro" do sistema.

Durante o encontro, Mano chega a rebater a afirmação do crítico, ao colocar que não havia a intenção de conduzir o sujeito para um tipo de experiência determinada e normatizada. Este poderia apenas olhar a distância, ou mesmo passar por ali desapercebido. Era um risco ao qual o trabalho (e o artista) estava submetido.

As controvérsias entre o ponto de vista do crítico e do artista em relação a vazadores, e as especificidades da crítica institucional aportadas em cada período histórico, não têm a intenção de estabelecer um juízo de valor entre uma prática artística e outra, mas pensar como o contexto mobiliza certas ações e como elas se tornam singulares em suas elaborações. No caso do 3Nós3, apesar de clandestino, o efeito de estranheza deveria ser amplamente disseminado pela mídia, e isso sim produzia resultados. Já no caso de Mano, o efeito de estranheza só era percebido pelo corpo do sujeito que a experimentava, uma vez que sua dissolvência na própria arquitetura do pavilhão e sua não divulgação como "arte" a colocava como um corpo estranho entre a bienal e o parque. Voltando ao texto de Fraser, o objeto ao qual a crítica de vazadores se direciona não é a instituição em si, mas as estruturas e códigos de uso contidas no seu modus operandi, que implicavam relações de poder entre a bienal e seus públicos, e entre a arquitetura e a cidade, algo semelhante ao que Crimp apontou na crítica materialista de Tilted Arc.

Fica claro, enfim, que o sentido de vazadores é proposto pelo artista como uma expressão de autoconsciência com relação à instituição. Ao mesmo tempo que a intervenção no pavilhão tensiona o acesso oficial à exposição, ela

285 Celso Favaretto apud Oliva, op. cit. traz à tona a historicidade daquele edifício relativa à utopia integradora da arquitetura moderna no contexto do parque. Ao mesmo tempo que o atravessamento é uma saída de emergência para a cidade, ele reconecta o pavilhão (e a instituição que está por trás dele) à sua vocação primordial na e para a capital paulista. Essa autoconsciência em relação à instituição se reafirma na declaração de Mano durante o debate da Pinacoteca: "O artista não é um criador de sociedades, tampouco deve se tornar um espelho passivo da realidade. Ele é apenas um membro da comunidade que não pode se afastar das condições do ambiente em que vive". ${ }^{286} \mathrm{~A}$ fala do artista reverbera no que Nina Felshin definiu com uma "nova arte pública", citada anteriormente, que inclui a comunidade e/ou o público na conceituação do lugar, e caracteriza o trabalho do "artista público" como sensível aos problemas, necessidades e interesses que define esse lugar.

Fica claro que o processo de criação de Rubens é movido por um intenso desejo de ação; este impulsiona o artista, leva-o a elaborar uma proposição que altera a condição do lugar, revelando certos aspectos encobertos, pela qual busca tirar o espectador de uma zona de conforto, instaurada no próprio circuito cultural artístico. Há um desejo implícito de se experimentar a transformação da percepção por meio de um deslocamento no espaço (protagonizado pelo observador) e do espaço (realizado pelo artista). A ambição de transformar essa percepção, isto é, de instaurar o espaço em ato, se mostra como um dos aspectos mais importantes desses trabalhos, onde reside sua expressividade, sua força política e seu sentido público.

Em vazadores, a construção de "um lugar dentro do outro" é agenciada como um movimento de atravessamento; o mesmo desejo de intensificação do fluxo entre as esferas pública e privada pode ser visto também em detetor de ausências, na singularização de cada indivíduo dentro da multidão que cruza o viaduto, e em calçada, pela conectividade estabelecida entre a instituição e a rua por meio do fornecimento de energia elétrica. As três si-

286 Rubens Mano apud Oliva, op. cit. 

moderno 
A profecia do escritor Stefan Zweig que deu nome ao seu livro Brasil, um país do futuro, ${ }^{287}$ publicado em 1941, parece ter relampejado em poucos momentos na história do país de lá para cá. O mais conhecido deles foi certamente a construção de Brasília, em 1960, que fincou a bandeira da capital federal, segundo seus princípios modernos, em meio à vasta terra virgem do cerrado na região central do país. Na história mais recente, a promessa também ressurgiu em meados dos anos 2000, como um despertar do "gigante adormecido", durante o chamado "boom das commodites", que coincidiu com o governo Lula, e no qual o país se "salvou" da crise mundial financeira de 2008 e se alinhou ao novo bloco econômico dos BRIC (acrônimo de Brasil, Rússia, Índia e China).

Apesar da profecia não ter consolidado suas bases estruturantes com vistas a superar o atraso civilizatório de um país marcado pela herança colonial escravocrata (e que mantém, todavia, suas constradições sociais e territoriais), o imaginário da vocação moderna do Brasil como uma nação voltada para o futuro está impregnado por toda parte. A bem dizer, ele é devedor da atuação de Juscelino Kubitschek, que na figura de presidente do Brasil lançou o slogan “50 anos em 5", pelo qual pretendia estabelecer o programa nacional desenvolvimentista e com ele colocar o país nos trilhos do progresso rumo ao futuro. Em seu livro de memórias, JK expõe o tom otimista do passado, simbolizado no projeto da nova capital federal. Segundo ele, Brasília deveria:

constituir a base de irradiação de um sistema desbravador [de desenvolvimento] [...], teria de ser, forçosamente, uma metrópole com características diferentes, que ignorasse a realidade contemporânea e se voltasse, com todos os seus elementos constitutivos, para o futuro. ${ }^{288}$

287 Zweig, Stefan. Brasil, um país do futuro [1ª edição 1941]. Rio de Janeiro: José Olympio Editora, 2006. 288 Juscelino Kubitschek apud Holston, James. Libertem o espírito de Brasília [1989/2010]. Xavier. Alberto e Katinsky, Julio (orgs.). Brasília: antologia crítica. São Paulo: Cosac Naify, 2012, p. 307. 
Brasília constitui o principal ícone de uma nação vocacionada para o que virá. A implantação de um discurso oficial promissor corroborou, ao mesmo tempo, a crença do nascimento de um novo modo de vida no país:

Muitos imaginavam que o universo de inovaçoes da cidade modernista [...] produziria um estranhamento radical que daria origem, nas palavras do relatório de 1963 da Novacap [...] à inexistência de discriminação de classes sociais [...], e assim [seria] educada, no Planalto, a infância que construirá o Brasil de amanhã, já que Brasília é o glorioso berço de uma nova civilização. ${ }^{289}$

De acordo com o antropólogo estadunidense James Holston, que pesquisou a capital federal e os viveres de seus primeiros habitantes - chamados candangos -, não só o poder público acreditava na possibilidade de uma "nação brasiliense", mas os próprios migrantes que aportaram na futura capital sentiam uma energia promissora e aberta ao experimental (nos termos de Holston):

Os pioneiros acreditavam que os experimentos de Brasília introduziriam novos hábitos sociais, instituições e padrões como modelos que transformariam tudo ao seu redor. Eles acreditavam em criar uma vida urbana brasiliense diferente não pelo exotismo, mas para estabelecer uma arena de experimentação na qual se resolvessem importantes problemas nacionais. ${ }^{290}$

Dois anos depois da inaguração de Brasília, esse mesmo "vir a ser" brasiliense era ironizado pela escritora Clarice Lispector em sua crônica sobre a capital: "Brasília é artificial. Tão artificial como devia ter sido o mundo quando

\section{Holston, op. cit., p. 307}

290 Ibidem, pp. 308-309. foi criado. Ouando o mundo foi criado, foi preciso criar um homem especialmente para aquele mundo". ${ }^{291}$ Como se sabe, a ideia de uma humanidade reprogramada é um embuste. No lugar dela, seus habitantes foram aos poucos imprimindo suas marcas naquele território, ainda que apartados social, econômico e espacialmente do plano piloto. Duas décadas mais tarde, eles se viram novamente de mãos atadas diante do tombamento como patrimônio histórico e cultural, 292 já que a cidade "oficial" não poderia mais crescer nem sofrer qualquer alteração em seu projeto original.

O imaginário moderno de Brasília não está somente no "espírito novo" (l'esprit nouveau) de seus viveres, mas aparece com frequência nas formas sinuosas assinadas pelo arquiteto. Sabe-se que a sensibilidade plástica de Niemeyer impregnou o vocabulário construtivo das cidades-satélites e se espraiou Brasil afora. A repercurssão simbólica dos edifícios do eixo monumental é apontada pelo historiador e arquiteto argentino Adrián Gorelik na seguinte passagem:

Sabe-se, por exemplo, que as tão características colunas do Palácio da Alvorada foram incorporadas maciçamente ao imaginário popular em todo o Brasil, reproduzidas em modestas arquiteturas populares como ícone de uma vontade de modernidade nacional e folclórica. Isso não é só um indício da aceitação popular de um "estilo" Brasília, mas também da capacidade de Niemeyer como produtor de símbolos - como icon giver-, cuja eficácia comunicativa deveria ser uma das vias de compreensão do fenômeno Brasília e de seu lugar específico na modernidade ocidental. ${ }^{293}$

291 Lispector, Clarice. Brasilia [1962]. Para não esquecer: crônicas. Rio de Janeiro: Rocco, 1999, p. 40. 292 O plano piloto de Brasília foi tombado primeiramente pela Unesco, em meados dos anos 1980 e, depois, pelo Iphan em 1990. Cabe lembrar ainda que, antes disso, alguns edifícios já tinham sido preservados, tais como o Catetinho, em 1959, e a Catedral, em 1967.

293 Gorelik, Adrián. Museu da modernidade [2007]. Xavier e Katinsky (orgs.), op. cit., p. 412. 
A capacidade plástica impressa nas soluções arquitetônicas de Niemeyer sinalizada por Gorelik nos edifícios públicos de Brasília já tinha sido comentada pela historiadora da arquitetura Françoise Choay momentos antes da inauguração da nova capital federal:

Quanto à arquitetura propriamente dita dos diferentes prédios em estrutura de concreto, caracteriza-se pelo uso, à frente das simples caixas envidraçadas, de uma espécie de cortina servindo tanto de apoio como de contraventamento e quebra-sol, e que, do teto plano em balanço até o piso, recorta o espaço por meio de fantásticos arabescos. Os edifícios públicos tornam-se grandes esculturas vazadas. ${ }^{294}$

Para a historiadora francesa, essas soluções construtivas demonstravam que a arquitetura também servia como deleite visual:

A obra de Niemeyer vem reabilitar a arquitetura como permanente deleite visual. Vem nos mostrar que uma grande cidade moderna não é necessariamente sinônimo de tédio provocado por arranha-céus padronizados e que, pelo contrário, pode ser impregnada de um valor poético. ${ }^{295}$

294 Choay, Françoise. Brasilila - uma capital pré-fabricada [1959]. Xavier e Katinsky (orgs.), op. cit., p. 63 295 Ibidem, p. 64

\section{A REVISÃO DO MODERNO PELA ARTE CONTEMPORÂNEA}

Desde pelo menos o final dos anos 1960, a arte brasileira tem se debruçado com mais ou menos afinco na revisão do projeto moderno edificado no país, com olhar especialmente voltado para o seu símbolo maior, que é Brasília. A revisão crítica tem atravessado diferentes abordagens: desde o aspecto projetivo (e idealizador) do partido adotado por Lucio Costa e sua equipe, vencedores do concurso para a capital federal; passando pela imagem icônica de seus edifícios públicos monumentais decorrente da habilidade plástica de Niemeyer; pela escuta de vozes dissonantes, como é o caso dos trabalhadores da construção civil que ergueram a capital; até o tipo de sociabilidade que ela teria produzido, passados 50 anos de sua inauguração.

Em meados dos anos 1970, a série de postais Brazil/Today (figs. 27 e 28), criada por Regina Silveira, expressava uma dessas vertentes. Em 1977, a artista se apropriou de um conjunto imagético do país, vendido pela indústria do turismo, pertencentes à "versão oficial dos fatos", e sobrepôs a essas imagens um desenho em serigrafia - ora uma pilha de sucatas automobilísticas, que bloqueia a rampa de acesso à arquitetura monumental do Palácio do Itamaraty, ora um grafismo geometrizado, cuja projeção espacial contém a organicidade de um grupo de indígenas em seus rituais. É um jogo de duplos construído pela desorganização-organização desses símbolos.

Entre os anos de 1980 e 1990, surgiram novos exemplos a partir da produção de artistas como: Emmanuel Nassar, com a pintura Brasília (1986), em que o ícone extraído do Palácio do Alvorada é enquadrado por uma faixa nacionalista verde-amarelista e rodeado por lâmpadas que reforçam a encenação da arquitetura de Niemeyer; Rosângela Rennó, com a obra Imemorial, que recupera a memória de trabalhadores que atuaram na construção de Brasília, por meio de documentos perdidos no Arquivo do Distrito Federal; e Robert Polidori, com suas fotografias do Núcleo Bandeirante, a antiga "Cidade Livre", o maior dentre os assentamentos improvisados que serviram de morada provisória para muitos migrantes. 

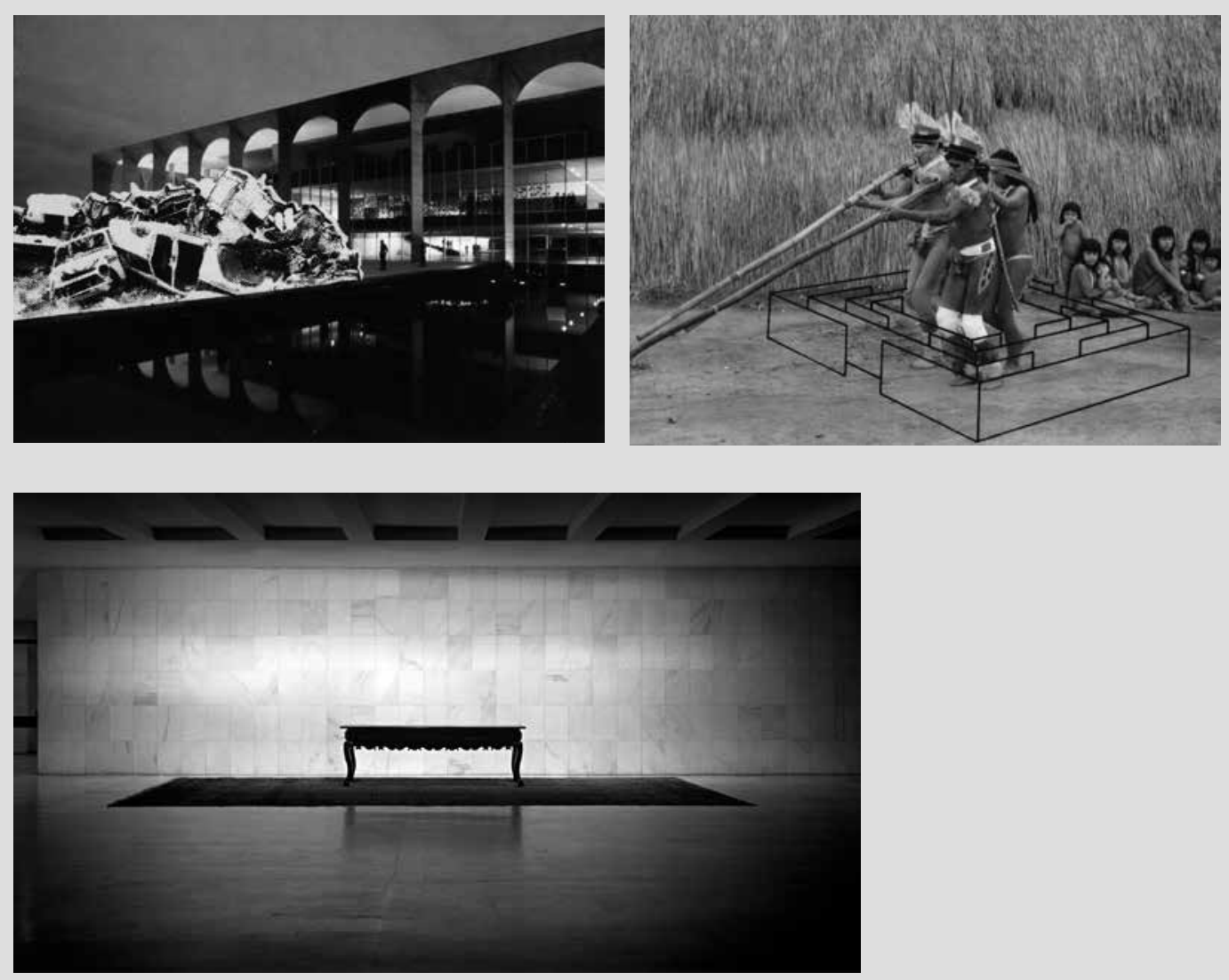

Mais recentemente, já nos primeiros anos deste século, a problemática moderna volta a figurar na produção brasileira, sob diversas formalizações. A série de fotografias Ministério das Relações Exteriores (fig. 29), de Caio Reisewitz, retrata os espaços internos da arquitetura de Niemeyer como um ambiente esvaziado, dando o tom de uma atmosfera inviolável e atemporal. Em Mármore branco todo dia (fig. 30), Clarissa Tossin registra em vídeo a equipe de limpeza diária do Palácio do Supremo Federal, especializada na manutenção do piso de mármore do edifício. De aspecto liso e uniforme, o mármore é um material alvo e de pouco desgaste, escolhido pelo arquiteto para revestir boa parte dos edifícios do poder; no vídeo, a artista questiona a quantidade descomunal de água e trabalho empregado na sua manutenção. Ainda na mesma década, em futuro do pretérito (2010), Rubens Mano cria uma dupla projeção videográfica que coloca lado a lado o dia a dia do plano piloto e das cidades-satélites, expondo como essas duas instâncias se contaminam mutuamente (obra que será central nas análises a serem desenvolidas neste capítulo).

Em plena década de 2010, as contradições da vocação moderna ainda vêm mobilizando artistas a lhe revisitarem. Evidências de uma farsa (fig. 31), de Carla Zaccagnini, ironiza a propaganda veiculada nas capas das revistas Time e The Economist, respectivamente das edições de 1956 e 2009, colocando lado a lado dois momentos da história do Brasil em que o país tentou alavancar-se como potência econômica mundial, mas que ao final foi frustado pelas contigências políticas em ação. No Projeto Cameleira 1971 (2014), Lais Myrrha reconstitui simbólica e fisicamente um dos maiores desastres da construção civil do Brasil, cujo projeto também era de Niemeyer, expondo a fragilidade do paradigma modernista no país. Em Banco Brasília (2015), Marcelo Cidade compõe a forma do Congresso Nacional a partir de objetos cotidianos: um banco de concreto (que alude à materialidade da arquitetura brasileira), sobre o qual posicionou duas garrafas de cerveja entre dois pratos brancos invertidos; garrafas e pratos esvaziados expressariam o empobrecimento da legitimidade Sina Silveir Série Brazil Today, 1977 Fotomontagem em serigrafia sobre cartão-postal, 10 × $15 \mathrm{~cm}$ (à esquerda: Natural Beauties: à direita: Indian

FIG. 29 Caio Reisewitz. Ministério das Relações Interiores (Palácio do (tamaraty) II, 2005 C-print montado em metacrilato, Contemporânea - MAC-USP dos congresssitas, de um lado, e a vulnerabilidade de um país ainda marcado pela fome, de outro. 

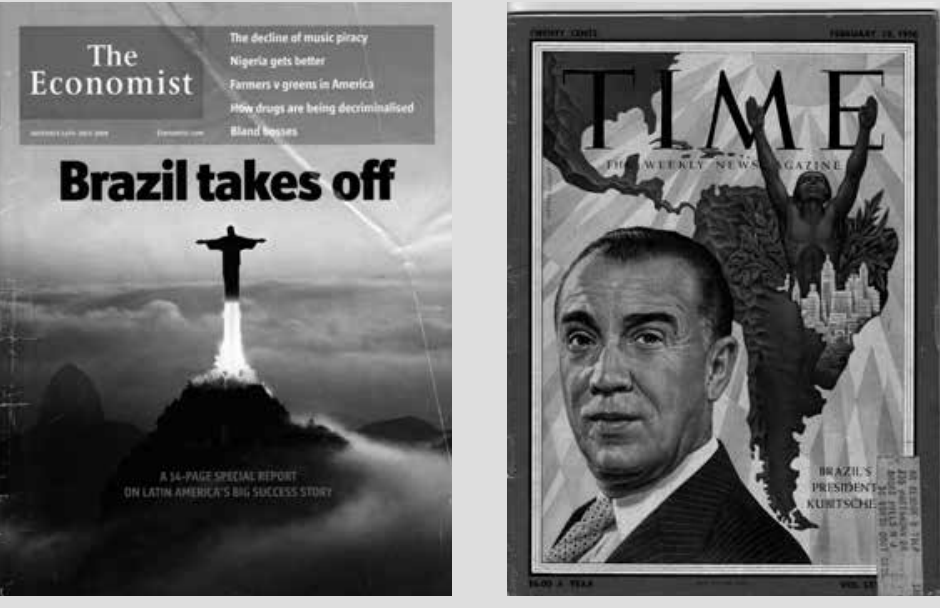

Nesta perspectiva da crítica renovada, que procura incessantemente compreender a nossa história moderna e as contradições intrínsecas ao contexto brasileiro, de hoje e de ontem, o terceiro e último conjunto de obras de Rubens Mano, ao qual este capítulo se dedicará, pretende abordar certos constructos sedimentados no país pela ideologia modernizante, expressos nas suas formas arquiteturais, no planejamento urbanístico, na habitabilidade forjada nesses espaços e nas apropriações e usos feitos deles ao longo do tempo. As obras que compõem o conjunto são: futuro do pretérito, de 2010; e imanente [adição_multiplicação_divisão_subtração_], de 2014, esta última apresentada como um corpo de obras que integraram a exposição homônima do artista, realizada no Centro Culural São Paulo (CCSP).

Desde pelo menos a experiência com vazadores, realizada em 2002, Mano vem elaborando um olhar crítico sobre a arquitetura moderna brasileira. No mesmo ano em que participou da 25 $5^{\underline{a}}$ Bienal, o artista registrou em espaço aberto/espaço fechado ${ }^{296}$ (fig. 32) o interior do Pavilhão Ciccillo Matarazzo em uma situação inusual, em que o espaço expositivo estava esvaziado. Esse vazio foi infinitamente replicado num ponto de fuga central armado por Mano no campo visual da fotografia; por sua vez, tal perspectiva foi reforçada pela maTha regular dos pilotis pintados de branco, que aos poucos vão diminuindo até se unirem ao fundo etéreo da cena. Devido à intensidade luminosa criada pelo artista, o pavilhão modernista converte-se momentaneamente em grau zero espacial, à espera de um evento, ao mesmo tempo que sua arquitetura torna-se ela a própria obra.

Do ponto de vista urbanístico, o olhar crítico de Rubens aparece sob o prisma da produção do espaço e da ressignificação desses contextos urbanos perseguidos pelo artista, principalmente em suas caminhadas por São Pau-

FIG. 30 Clarissa Tossin Mármore branco todo dia, 2009 Vídeo HD em dois canais, 5'42", cor, som, loop. (Disponível em: <https:// vimeo.com/25168796>)
FIG. 31 Carla Zaccagnini. Evidências de uma farsa (2011) Montagem com as edições das revistas Time e The Economist, respectivamente de 1956 e 2009; $26,5 \times 20 \mathrm{~cm}$ e $27 \times 20,5 \mathrm{~cm}$. Coleção Solomon R. Guggenheim Museum, Nova York

296 A fotografia de Mano chegou a emprestar título para uma exposição dedicada à arte brasileira realizada no Instituto Henri Moore, em Leeds, na Inglaterra. Em Espaço aberto/espaço fechado: sites para escultura no Brasil moderno, o curador Stephen Feeke elegeu a I Bienal de São Paulo como disparadora para o debate sobre o espaço moderno na produção brasileira. 


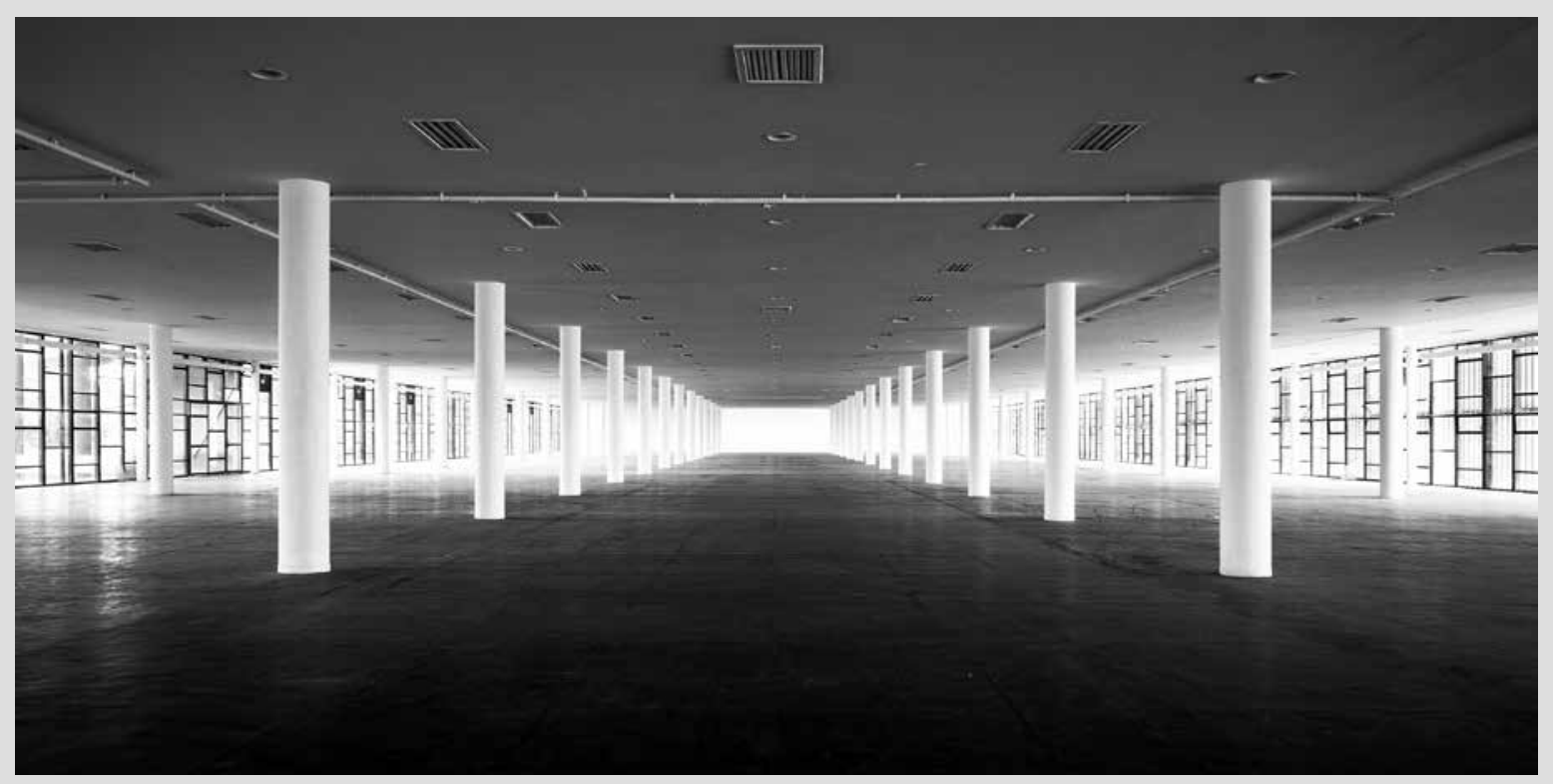

ta se revelou, sobretudo, um grande exemplo do espírito moderno devido à sua lógica da tábula rasa, pela qual não cessa de destruir-se e construir-se a si mesma, Brasília se mostrará paradoxalmente neste capítulo como a antítese paulistana, uma vez que o projeto de futuro da capital federal parece ter ficado preso ao passado. Portanto, se os capítulos 2 e 3 trataram com mais afinco da produção do espaço na cidade e no espaço urbano, no Capítulo 4 o foco será a produção do espaço constituída a partir da arquitetura e do planejamento urbano (modernos), e reformulada pelos usos feitos deles ao longo do tempo.

Sob o título Habitar o moderno, as proposicões de Mano a serem analisadas neste conjunto se destacam por remeterem dialeticamente aos símbolos mais evidentes desse espírito desenvolvimentista que singularizou a arquitetura e a urbanística modernas produzidas no país. Em futuro do pretérito, o artista revela a existência de várias Brasílias dentro de um único projeto de cidade que "parou no tempo" (a obra é proposta justamente no momento em que são celebrados os 50 anos da inauguração da capital federal). Já em imanente, a partir do elemento construtivo do tijolo cerâmico, Mano especula sobre o programa nacional de habitação do governo federal, colocando frente a frente no tempo unidades do BHN e do MCMV (a instalação foi concebida para o CCSP em 2014, no mesmo ano em celebrava-se os 50 anos de criação da primeira política habitacional do país em nível nacional). O embate entre o público e o privado ressurge em ambos os exemplos.

A hipótese que se apresenta nessas proposições de Mano as reúne em torno de uma elaboração crítica revigorada sobre o projeto arquitetônico moderno diante da crítica corrente que se produziu nos anos 199o, uma vez que abidica-se de seu aspecto condenatório sobre o "fracasso" da utopia modernista, em busca de uma visada menos maniqueísta, em que duas situações antagônicas convivem e se contaminam mutuamente (coincidindo com o que Laymert apontara como a possibilidade de atuação do artista de forma positiva em relação à problemática urbana). O que se mostrará mais interessante e potente nessas obras é o modo dialético como o artista articula situações espaciais contraditórias entre o moderno e o popular, nas quais o fechado, 2002 aberto/espaço

Fotografia, impressão lambda em papel RC montada em metacrilato, $125 \times 250 \times 3 \mathrm{~cm}$ 
situações espaciais do plano piloto e das cidades-satélites; e, no segundo, pela apropriação do elemento vernacular do tijolo de barro por parte do programa de produção massiva de moradias em escala nacional.

Antes de um mergulho de fato nas obras, será preciso examinar brevemente as peculiaridades e contradições do projeto moderno em terras brasileiras.

\section{PROJETO MODERNO BRASILEIRO: CONTRADIC̣ÕES DE ORIGEM}

Vou agora escrever uma coisa da maior importância: Brasília é o fracasso do mais espetacular sucesso do mundo. (Clarice Lispector) ${ }^{297}$

Digam o que quiserem, Brasília éum milagre. (Lucio Costa) ${ }^{298}$

"O nosso passado não é fatal, pois nós o refazemos todos os dias. E bem pouco preside ele ao nosso destino. Somos, pela fatalidade mesma de nossa formação, condenados ao moderno". ${ }^{299}$ A frase célebre foi proferida por Mário Pedrosa durante sua comunicação no Congresso Internacional Extraordinário de Críticos de Arte ocorrido em Brasília em 1959. ${ }^{300}$ A expressão grafada por Pedrosa tornou-se um mantra recorrente em ensaios críticos dedicados à revisão do projeto moderno nacional (principalmente na arquitetura e na arte, mas também em estudos culturais em geral). Ela expõe as contradições de

297 Lispector, Clarice. Brasilia esplendor [1974]. Para não esquecer: crônicas, op. cit., p. 46.

298 Costa, Lucio. Consideraçōes fundamentais [1988]. Registro de uma vivência. São Paulo: Empresa das Artes, 1995, P. 323. (O depoimento de Lucio Costa foi publicado originalmente em 31 de agosto de 1974, na revista Manchete, e posteriormente editado no artigo de 1988.)

299 Pedrosa, Mário. Brasilia, a cidade nova [1959]. Arquitetura: ensaios críticos. Org. Guilherme Wisnik. São Paulo: Cosac Naify, p. 93. (A comunicação de Pedrosa foi publicada originalmente no Jornal do Brasil, em 19 de setembro de 1959.)

300 O congresso foi realizado pela Associação Internacional de Críticos de Arte - AICA, sob a organização de Mário Pedrosa e Mario Barata, e teve a participação de renomados críticos de arte, arquitetos e urbanistas estrangeiros, dentre os quais Meyer Schapiro, Giulio Carlo Argan, Bruno Zevi. Richard Neutra, Sir William Holford e Gillo Dorfles. O evento ocorreu concomitantemente em três cidades, São Paulo, Rio de Janeiro e Brasília. A abertura se deu na nova capital federal, antes mesmo de sua inauguração, e contou com a presença de Juscelino Kubitschek Sob o título "Cidade nova, sin-

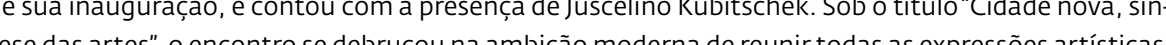

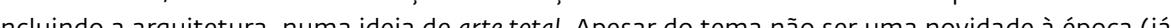
consolidado sobretudo pela Ba has), o inedismo do congresso residi justa

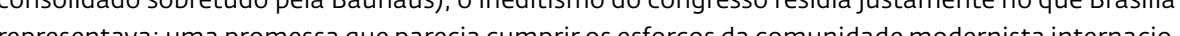

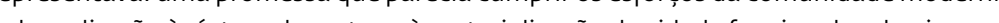

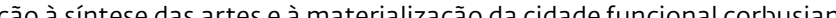


origem do projeto diante de uma jovem nação subdesenvolvida, fundada na periferia do capitalismo.

A expressão de Pedrosa alude a uma ausência de "tradição" em comparação à civilização europeia, que até o início do século XX nos fornecia os modelos e paradigmas da linguagem artística a serem seguidos. Ao examinar as razões dessa ausência, o crítico de arte encontrou suas origens nos escritos do geógrafo francês Pierre Monbeig sobre o Brasil, publicados em 1952 no livro Pioneiros e fazendeiros de São Paulo. Segundo este, a história do país foi marcada desde o começo por uma "frente de colonização", protagonizada por uma gente que se caracterizava "pelo gosto e à procura do novo, a vontade de não se contentar com a herança do passado". ${ }^{301}$

No despontar do século XX, ainda sob a égide de uma cultura colonizada, o espírito moderno contagiou os artistas mais arejados do país, organizados na frente modernista da Semana de 22; porém, ao mesmo tempo que defendiam uma renovação linguística, rompendo principalmente com o academicismo das belas-artes (tal como os seus pares europeus), eles estavam imbuídos de um profundo comprometimento com a construção de uma identidade nacional, que de alguma forma os aproximava da política de Estado desenvolvida a partir dos anos 1930

Sobre o panorama de contradições da arte brasileira da primeira metade do século XX, entre o moderno e a tradição, o crítico de arte Rodrigo Naves coloca que:

foi esse compromisso com a edificação de um imaginário positivo a razão de quase todos esses artistas manterem em relação a seus meios expressivos - fossem eles pictóricos ou escultóricos - uma atitude de comedimento e de pouca radicalidade, uma vez que a preocupação de firmar comunicativamente os símbolos que construíam - mulatas,

301 Pierre Monbeig apud Pedrosa, Mário. Brasilia, a cidade nova. Arquitetura: ensaios críticos, op. cit. 2015 [1959], p. 95 camponeses ou estranhas figuras semifolclóricas - necessariamente pedia de seus trabalhos um certo compromisso com formas tradicionais de percepção. ${ }^{302}$

A leitura de Naves explicaria, em parte, por que a integração das artes pressuposta na utopia moderna das vanguardas do início do século XX tinha sido absorvida pelo projeto desenvolvimentista de Juscelino Kubitschek - na sua maior realização, que foi a construção de Brasília - com feições mais nacionalistas do que estritamente modernas e disruptivas. A preferência oficial pelos modernistas da geração de 1930 - tais como Candido Portinari, Di Cavalcanti e Alfredo Ceschiatti - para representar a integração nacional entre arte e arquitetura em Brasília refletira essa limitação. Boa parte das obras selecionadas para o plano piloto ${ }^{303}$ acabou figurando muito mais como representações nacionais que celebram um "tipo" brasileiro do que como protagonistas de uma autêntica renovação (entre forma e conteúdo) pari passo com as ideias urbanísticas impressas no projeto modernista de Lucio Costa para a capital.

É sabido que a principal característica das vanguardas europeias foi a bandeira da ruptura com o passado e sua história - quer por via de uma concilia-

O2 Naves, Rodrigo. Azar histórico: desencontros entre moderno e contemporâneo na arte brasileira, Novos Estudos, Cebrap, n. 64, nov. 2002, p. 7

303 Em sua tese de doutorado, Heloisa Espada levantou quem eram os pivôs das escolhas: "A escolha das obras de arte que ocupariam a praça dos Três Poderes, os interiores dos palácios e outros lugares públicos de Brasília foi um assunto discutido e ponderado entre Israel Pinheiro, diretor da Novacap, Oscar Niemeyer, diretor do Departamento de Arquitetura e Urbanismo da companhia, e Lucio Costa, responsável pelo projeto urbanístico. Depoimentos dos dois arquitetos e do artista Athos Bulcão dão a entender que Lucio Costa se envolvia principalmente na decisão sobre as obras que ocupariam os espaços abertos da cidade, enquanto cabia a Oscar Niemeyer escolher os artistas e trabalhos que integrariam os interiores de seus projetos. Uma exceção é o Palácio do Itamaraty, cuja formação do acervo de arte moderna e contemporânea aconteceu por iniciativa e influência do ja formaçăo do dimir Murtinho [ ] percebe-se que as decisões envolviam questões orçam relaçóes e gostos pessoais, além da preocupacão com a manutencão do sentido de unidade éas,

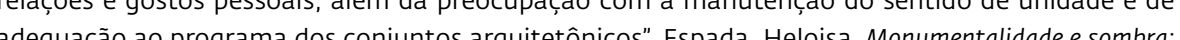

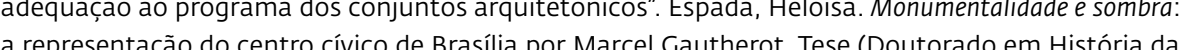
Arte) - Escola de Comunicações e Artes - ECA-USP, 2011, p. 177. 
ção possível entre arte e indústria, quer pela negação desta relação, por meio de uma estratégia de choque -, almejando o novo (e o futuro) como horizonte. Conforme escreveu o crítico de arte Ronaldo Brito,

A Modernidade apresentava de início um sentido manifestadamente liberatório, caracterizava-se pela disponibilidade absoluta: parecia possível fazer tudo, com tudo, em qualquer direção. [...] Mas o gesto de liberar implica uma situação de opressão, uma situação insustentável. A liberdade moderna não era simplesmente a afirmação de novas possibilidades: era sobretudo uma revolta, um desejo crítico frente às coisas e valores instituídos. No limite, expressava o paradoxo de um sujeito que não reconhecia mais o mundo enquanto tal. ${ }^{304}$

A libertação da arte moderna, tal como apresentada por Brito, implicou não só uma ruptura com o passado, mas uma "disponibilidade absoluta" (em termos plásticos e conceituais) para tudo o que poderia vir a ser, uma vez que rompia com o principal estatuto da arte, qual seja o da representação do mundo. De par com isso, construiu uma linguagem voltada sobretudo para, de um lado, pensar a si própria (seus elementos plásticos, sua fatura, as qualidades dos materiais etc.), e, de outro, para restabelecer os vínculos com o mundo, o qual não mais respondia aos seus anseios.

No contexto brasileiro, a aproximação arte-vida almejada pela utopia moderna grosso modo manifestou-se na conciliação entre as esferas da arte $e$ da indústria; porém, ela só foi ocorrer em meados da década de 1950, quando da formação de um espírito construtivo entre os artistas, facultado pelo contexto paulista. O descompasso do ideal moderno de aproximação da arte à nova realidade industrial (urbana, por excelência), verificado entre os modernistas de 1922 e o concretismo paulista dos anos 1950, se explica também

304 Brito, Ronaldo O moderno e o contemporâneo (o novo e o outro novo). Basbaum (org) op cit. p. 202. pela formação tardia de um parque industrial substancial, a partir da década de 1940, e que coincidiu com a sua criação em território paulista. Contudo, a vanguarda construtiva da arte brasileira não teve participação de peso no projeto da nova capital para formular as bases de uma nova visualidade condizente com os anseios do espírito moderno dos autores de Brasília - talvez, justamente, por não carregar mais aquele espírito nacionalista das primeiras décadas.

Quanto à arquitetura e ao urbanismo, em termos mundiais, a visão otimista sobrepujou à negativa (pelo menos até o período do pós-guerra), e construiu um modelo utópico de cidade esboçado na Carta de Atenas redigida no IV Congresso Internacional de Arquitetura Moderna (CIAM), em 1933. Nela, os princípios urbanísticos de racionalidade e planificação da "cidade funcional" de Le Corbusier ${ }^{305}$ alinhavam-se às soluções estandardizadas da arquitetura moderna; esta era "pensada como a principal aliada na solução dos grandes antagonismos da sociedade capitalista, a que seria capaz de reorganizar por uma reordenação do espaço". ${ }^{306}$ Segundo Otília Arantes, a "ideologia do plano", proveniente de uma ordem planificada e abstrata, era justificada pela possibilidade emancipadora da industrialização com vistas a resolver o problema do déficit habitacional (em boa parte, ocasionado pelo crescimento populacional urbano e pelas destruições da guerra em solo europeu).

305 Os princípios do urbanismo funcionalista redigidos na carta e encabeçados por Le Corbusier durante o IV CIAM, realizado em Atenas em 1933 estabeleciam o zoneamento funcional das cidades, cujas áreas deveriam ser dividas pelas atividades ali realizadas - a saber, morar, trabal har, circular e lazer Além disso, pregava-se uma ocupação extensiva em conjuntos habitacionais de grande porte, estandardizados para uma maior eficiência técnica e conômica. Cf Carta de Atenas. Atenas: iv

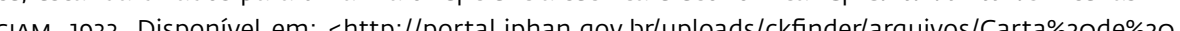
CIAM, 1933. Disponivel em. <http.//portaliphan

306 Arantes, op. cit., 2001, p. 25 


\section{BRASÍLIA: DESCOMPASSOS DO PROJETO}

A construção de Brasília fez conviver anacronicamente o espírito colonizador próprio dos "fundadores" da nação brasileira, mencionado por Pedrosa, e o esprit nouveau de Le Corbusier, que se lançava entusiasticamente na direção do futuro. No discurso de Lucio Costa, principal autor do projeto da nova capital, aparecem ambos os sentidos. No "Memorial descritivo do projeto", datado de 1957, o arquiteto defendia a fundação da capital como "um ato deliberado de posse, um gesto de sentido ainda desbravador, nos moldes da tradição colonial". ${ }^{307}$ Dez anos mais tarde, em "O urbanista defende a cidade", seu entusiasmo seguia na compreensão de Brasília como "o coroamento de um grande esforço coletivo em vista ao desenvolvimento nacional", ${ }^{308}$ que "pela singularidade da sua concepção urbanística e da sua expressão arquitetônica, testemunha a maturidade intelectual do povo que a concebeu, empenhado na construção de um novo Brasil, voltado para o futuro". ${ }^{309}$

De modo geral, foram os princípios modernistas da Carta de Atenas de 1933 que orientaram o projeto apresentado pela equipe de Lucio Costa, vencedora do "Concurso para o Plano Piloto da Nova Capital do Brasil", em 1957. A palavra final do júri ${ }^{310}$ (não tão unânime assim...) denotava escolhas baseadas nos espíritos de euforia e ufanismo daquele momento, predominando as decisões políticas e os usos ideológicos da construção de um emblema nacional e da retórica modernista.

307 Costa, Lucio. Memorial Descritivo do Plano Piloto [1957]. Lucio Costa: registro de uma vivência, op. cit., p. 283.

308 Costa, Lucio. O urbanista defende a sua cidade [1967]. Lucio Costa: registro de uma vivência, op. cit., p. 301 .

310 O júri foi composto por Israel Pinheiro (presidente da Novacap), Paulo Antunes Ribeiro (representante do IAB), Luiz Hildebrando Horta Barbosa (Associação dos Engenheiros), Oscar Niemeyer e Stamo Papadaki (Departamento de Urbanismo da Novacap), o urbanista inglês William Holford e o arquiteto francês André Sive.
Na concepção do arquiteto, Brasília se orientaria pela organização da vida citadina em quatro escalas de uso: monumental, residencial, gregária e bucólica. O conjunto delas lhe conferiria seu duplo caráter, como urbs e como civitas. A primeira escala foi projetada no eixo monumental, e reuniria os edifícios ministeriais, o congresso e os palácios. A escala residencial cortaria o primeiro eixo ortogonalmente (formando o desenho cruciforme do plano piloto) e organizaria a função do morar nos espaços interiorizados das superquadras (esta era composta de quatro volumes horizontais com gabarito de 6 pavimentos, a fim de que as famílias pudessem avistar seus filhos nos pátios internos da quadra). A escala gregária se daria no cruzamento das duas primeiras, onde foi posicionada a rodoviária; ali seriam alocados os setores de banco, comércio e lazer, dentre outros. A escala bucólica, por fim, coroaria o desenho da capital com a vista do cerrado no horizonte de Brasília.

De acordo com o historiador e arquiteto Guilherme Wisnik, tais escalas se mostraram dicotômicas, pois cerceavam as trocas sociais próprias dos centros urbanos, causando uma impressão solitária da vida brasiliense:

Na relação dicotômica criada entre o espaço interiorizado da superquadra e a absoluta extroversão da escala monumental, a antiga forma de apropriação pública da cidade, pautada pela mistura, pela troca, está subtraída, donde uma permanente e incômoda sensação de solidão. Pois o que devia ser sentido como igualdade pode ser facilmente transformado em anonimato. ${ }^{311}$

"Em Brasília não existe cotidiano", ${ }^{312}$ como dizia Clarice... Aos olhos da escritora, faltam-lhe as esquinas, os encontros, os botecos para tomar um cafezinho nas pausas do trabalho, os postes para os cachorros fazerem xixi...

311 Wisnik, Guilherme. Transpondo a escala [2001]. Xavier e Katinsky (orgs.), op. cit., p. 374 312 Lispector, Clarice. Brasília esplendor. Para não esquecer: crônicas, op. cit., p. 44. 
Com efeito, a relação entre o privado e o público (e sua integração), própria de uma sociabilidade urbana, soa muito distante dos objetivos do plano piloto de Lucio Costa. Segundo a socióloga Sophia da Silva Telles:

Lucio parece substituir essa relação [entre o privado e o público] pelas noções de espaços íntimos e monumentais. Para ambas as escalas, é a preeminência da paisagem agreste e dos amplos espaços que confere ao seu projeto urbanístico uma diferença também em relação às novas cidades desenhadas pelos projetos da arquitetura moderna. ${ }^{313}$

No plano piloto, o tratamento especial dado ao paisagismo - enquanto espaço sensível - ecoa nas reminiscências de infância do seu autor, vivida na Inglaterra, onde a natureza tem valor especial. Lucio Costa dizia que "o urbanismo consiste em levar um pouco da cidade para o campo e trazer um pouco do campo para dentro da cidade". ${ }^{314} \mathrm{Na}$ zona residencial, por exemplo, o uso do paisagismo ao redor dos edifícios horizontais os dissolvia não apenas no nível da visão, como também "em seu caráter propriamente urbano, defendendo o tratamento rústico das ruas e calçadas que deseja ver quase abolidas". 315

O idealismo moderno impresso no projeto para a capital federal foi desde o início marcado por contradições. As críticas surgiam mesmo antes da inauguração de Brasília, em 1960. Mário Pedrosa era uma dessas vozes. Em seu artigo "Reflexões em torno da nova capital", de 1957, o crítico pondera que a fundação de uma capital longe das zonas já ocupadas natural e culturalmente significava uma espécie de tábula rasa da sua própria história:

Eis que surge a ideia de se criar uma nova capital precisamente para esse Brasil que já superou a fase colonial dos oásis. Mas como? Pelo velho processo das “tomadas de posse” da terra quase simbólicas, pe-

313 Telles, Sophia da Silva. Brasília - O desenho da superfície [1989]. Xavier e Katinsky (orgs.), op. cit., p. 328 314 Costa, Lucio. Urbanismo [1972]. Registro de uma vivência, op. cit., p. 277.

315 Telles, op. cit., p. 327 las implantações maciças de civilizações e a dominação mecânica de um solo despovoado, solitário, por uma técnica importada. [...] Não é à toa que algo de contraditório se esconde no invólucro moderníssimo de sua concepção. [...] Seria possível construir-se a nova capital fora das áreas de civilização naturalizada, onde desabrocharam enfim os primeiros rebentos de uma cultura organizada e autóctone?316

Da mesma forma, os elogios de Françoise Choay à Niemeyer misturavam-se à sua crítica contundente sobre a tábula rasa:

Nenhum estabelecimento humano jamais havia sido erguido no local da futura Brasília; nenhuma estrada levava até lá. Era uma legítima tábula rasa, como a imaginamos nas utopias científicas ou filosóficas e que, numa única vez, a história de fato confiava a dois famosos arquitetos. ${ }^{37}$

Decerto que as antinomias do projeto moderno cristalizado em Brasília marcaram a cidade desde antes de sua fundação. Do ponto de vista político e ideológico, relativizava os princípios da ruptura com a tradição, ao pretender restaurar os fundamentos de uma nação. Do ponto de vista artístico, seus artistas "oficiais" buscaram garantir a efetividade do discurso nacional-desenvolvimentista por meio de "formas tradicionais de percepção" para sua aceitação. Em termos urbanísticos, a transposição da utopia modernista de

316 Pedrosa, Mário. Reflexões em torno da nova capital [1957]. Arquitetura: ensaios críticos, op. cit., p. 134. Aqui, a ideia de uma civilização-oásis diz respeito à origem de um povo surgido artificialmente. Ela é recuperada por Pedrosa a partir dos estudos de Wilhelm Worringer sobre o Antigo Egito de 1927. e sua analogia com os povos da América ("lugar onde tudo podia começar do comeco"): "O Egito, na verdade, não tinha cultura mas uma civilizaç̃o. E o grande historiador de arte comparava o papel do Egito a da América na idade contemporânea O ponto de comparaça ara dado pela 'força de transforma ca Amo possui toda cultura não autóc. O ponto de compar açao era dado pela força de transfor açáo que possuitoda cultura náo autoctone' por he faltaremas resistencias, os obstáculos

317 Choay, op. cit., p. 60 
Le Corbusier, que pretendia resolver um problema de ordem social a partir de uma lógica industrial e funcionalista, acabou fazendo da história do país uma tábula rasa, cujo ponto zero foi fincado em Brasília.

Esses descompassos do projeto moderno entre as versões europeia e brasileira também foram tratados por Gorelik no seu ensaio sobre Brasília de 2007:

A negação da história da Bauhaus, a "tradição do novo" vinculada ao culto do método empírico e do mundo tecnológico, buscava produzir, como assinalou Manfredo Tafuri, objetos artísticos que só podem viver no presente. Desse ponto de vista, a experiência do modernismo brasileiro em sua versão canônica poderia ser vista como uma completa inversão: a finalidade do objeto artístico é produzir ao mesmo tempo um futuro e sua tradição: porque o problema que deve resolver é a ausência de história, não seu excesso. ${ }^{318}$

Para além das contradições do projeto moderno brasileiro, os princípios da cidade funcional estabelecidos na Carta de Atenas já vinham sendo ques tionados desde as experiências de reconstrução das cidades europeias no pós-guerra. Ao longo da segunda metade da década de 1950, as discussões encabeçadas pela nova geração de arquitetos do CIAM criticavam o processo de reconstrução pelo caráter abstrato de suas propostas, culminando na sua extinção, em 1959. A última edição do congresso foi conduzida pelo grupo do TEAM 1o, que defendia a importância de se olhar para a cidade real existente e dialogar com os padrões de vida da população e com as condições culturais locais. ${ }^{319}$

\section{Gorelink, op. cit., p. 413}

319 Barone, op. cit., p. 65

\section{A REATUALIZACÃO DA CRÍTICA NOS ANOS 1990}

Entre 1964 e 1984, Brasília foi “blindada” pelos militares e, com ela, a crítica sobre o projeto de modernização do país.

[...] após 1964, torna-se claro que aqueles horizontes se haviam fechado sob o impacto de um trágico desfecho histórico, a partir do qual a possibilidade emancipadora da industrialização toma o caminho restritivo da homogeneização cultural, problematizando assim aquelas afinidades utópicas que desde 1936 haviam definido a relação de colaboração entre a vanguarda artística e um Estado universalizador, na periferia do capitalismo. ${ }^{320}$

Entre a inauguração de Brasília e o início da redemocratização, em meados dos anos 1980, o país foi tomado de assalto por governos ditatoriais que assombraram qualquer tipo de opinião pública livre, bem como a liberdade de imprensa, especialmente no que diz respeito à atividade crítica. Como bem observou o historiador e urbanista Renato Cymbalista, a ditadura militar represou a valorização da esfera pública surgida na década de 1960 na figura espacial da rua ${ }^{321}$ e liderada nos Estados Unidos pelo ativismo de Janes Jacob, dentre outros. ${ }^{32}$ Para o historiador, a crítica que se fazia sobre a falta de vitalidade das ruas da capital só recuperou fôlego em meados dos anos 1990. Ela coincide com o surgimento de uma geração de artistas e curadores que passou a olhar para as cidades com mais interesse - a exemplo dos trabalhos de Mano e dos projetos de Nelson Brissac.

Em meados dos anos 1980, ao período de blindagem política da capital federal sobrepôs-se seu congelamento como patrimônio histórico cultural,

320 Wisnik, op. cit., p. 374.

321 Cymbalista, op cit, 70.

322 Cf. Jacobs, Jane. Mortee vida de grandes cidades. São Paulo: Martins Fontes, 2011. 
pelo qual o plano piloto de Brasília, projetado para uma cidade de 500 mil habitantes, foi tombado pela Unesco e tornou-se um bem cultural mundial inviolável. Nesse momento, os estudos realizados por James Holston sobre a capital revelaram que Brasília havia se transformado à época na maior área urbana tombada do mundo e na única cidade viva contemporânea tão preservada $^{323}$ (contrastando com o fato de a capital federal ser uma das cidades mais desiguais do país no mesmo período, segundo o levantamento de Holston).

As controvérsias do processo de patrimonialização da "cidade-museu" foram igualmente debatidas pelo filósofo alemão Max Bense em 2009, quando este atualizou suas críticas sobre a capital, escritas originalmente nos anos 1960, incorporando às discussões a questão do tombamento e os limites da produção do espaço que ela impunha a seus habitantes:

A cidade terá de conservar para sempre uma relação de confiança com a inteligência racional, e o pensamento de instalá-la como cidade pronta e acabada denota a intenção de retirá-la do fluxo da história a fim de preservá-la da fragilidade. A vida, que entrou livre e de modo intensivo na história da civilização, sai atada e de modo extensivo, e os momentos mutáveis e vegetativos tornam-se enredados em momentos irremediavelmente estruturais. ${ }^{324}$

Como uma cidade tão jovem e "moderna" poderia ser congelada no tempo? Se o espírito de Brasília é o do experimento, tal como o define Holston a partir do olhar candango, não seria contraditório que a possibilidade de transformação dessa cidade, bloqueada desde sua concepção, esteja blindada juridicamente, reforçando ainda mais a segregação estabelecida desde a concepção do plano piloto? (Lembrando que a cidade completa implicava, contudo e apesar da advertência de Lucio Costa, um modelo de ocupação do

\section{Holston, op. cit., p. 310}

324 Bense, Max. Inteligência brasileira - Brasilia [1965/2009]. Xavier e Katinsky (orgs.), op. cit., p. 107 solo que não permitia o acréscimo de tecido urbano novo no core planejado para 500 mil habitantes.)

Holston considera que o tombamento do plano piloto representou a "traição" do espírito brasiliense pelos seus próprios fundadores, uma vez que "ao preservar a cidade como seu próprio memorial, nega às gerações subsequentes de cidadãos brasilienses o seu direito à cidade, a oportunidade de fazê-la sua e construir a cidade que eles desejam habitar". 325

Os privilégios e desigualdades apresentados nos estudos do sociólogo norte-americano nos anos 1980 relevaram que eles foram gerados não necessariamente pelos fatos que se seguiram depois da inauguração de Brasília, mas, sobretudo, devido às premissas modernistas calçadas no modelo funcional de cidade, fadado à segregação espacial.

Da mesma forma, a historiadora da arquitetura Sylvia Ficher também identifica na concepção original do projeto de Lucio Costa aspectos que reforçariam a tese da antinomia instaurada pela "completude" da cidade planejada:

Para defender e preservar a sua completude, foi definido um cinturão verde - melhor dizendo, um cordon sanitaire - e adotada uma política de expansão pela implantação de subúrbios e cidades-dormitórios para abrigar a população mais pobre - as cidades-satélites. À cidade Livre, atual Núcleo Bandeirante, acampamento de migrantes em busca de trabalho nas obras de construção, iriam se seguir Taguatinga (1858), Sobradinho e Gama (1960), Guará (1966), Ceilândia (1970) e assim indefinidamente... ${ }^{326}$

O "choque do novo" - conhecido por "brasilite", e vivido pelo povo candango - transformou-se em "choque de realidades". De um lado, tem-se o plano piloto duramente protegido por uma legislação que impede o surgimento de

325 Holston, op. cit., p. 309

326 Ficher, Sylvia. Algumas Brasílias [2000]. Xavier e Katinsky (orgs.), op. cit., p. 364 
um tecido urbano contínuo e restringe o desenvolvimento de tipologias mais ajustadas às necessidades dos habitantes. De outro, às cidades-satélites cabe a repetição das disposições urbanísticas da cidade oficial tombada, transpostas de maneira apressada, disfuncional e desordenada (contando ainda com verbas bem inferiores).

Nesse breve apanhado da crítica que se produziu sobre Brasília, princi palmente a partir do período da redemocratização, buscou-se sinalizar como é frequente a ocorrência de uma posição conflituosa de seus comentadores. Elogios são geralmente entremeados por duras críticas e vice-versa: as brilhantes soluções arquitetônicas de Niemeyer são postas em confronto com uma volumetria monumental e totalitária; a valorização da paisagem no entorno do plano e das áreas residenciais (o cinturão verde de Lucio Costa) é tida muitas vezes como um instrumento urbanístico segregador (um cordon sanitaire); o "espírito de Brasília” lançado pelos próprios candangos ("ousar um futuro diferente" e "abraçar o moderno com um campo de experimento e risco" ${ }^{327}$ contradiz a valorização da preservação do plano piloto, que acabou congelando a cidade por meio do seu tombamento.

É justamente a partir dessa experiência ambígua e aparentemente conflitante que as obras de Rubens Mano serão estudadas a seguir. Por meio delas, o artista elabora sua visão sobre o projeto moderno ensejado no país e os modos de vida dali decorrentes, especialmente no caso da capital federal, destacando uma ideia de mútua impregnação, espacial e social, entre as realidades oficial e "extra-oficial". 
Em 2009, Mano elaborou um projeto de instalação audiovisual que tinha por objetivo esmiuçar os modos de vida ensejados na capital federal, associando simultaneamente os viveres urbanos nos espaços abertos do plano piloto e nos espaços de convívio público nas cidades-satélites. O pressuposto tomado pelo artista buscava investigar de que modo a produção arquitetônica e o planejamento urbano modernistas foram (e são) tensionados pelos diversos agentes anônimos que atuam nos espaços das cidades e os modificam infinitamente. A obra deveria conter, assim, duas projecões audiovisuais com imagens captadas no dia a dia desses lugares, sendo uma dedicada à cidade oficial (plano piloto) e a outra dedicada à cidade informal (cidades-satélites).

O projeto foi contemplado pelo edital Arte e Patrimônio 2009, pelo qual Rubens pode desenvolver sua proposta. Como parte do projeto do artista ao final, a obra futuro do pretérito foi exposta no Museu de Arte Honestino Guimarães (também conhecido por Museu Nacional da República), entre 27 de janeiro e 28 de fevereiro de 2010. ${ }^{329}$ A opção pelo Museu da República, cujo projeto também é assinado por Niemeyer, reforçava o grau de interlocução entre a obra e o meio - ou o que outrora foi colocado nos termos do par dialético espaço e imagem de espaço.

328 Lispector, Clarice. Brasília esplendor, op. cit., p. 50.

329 Ainda em 2010, a obra futuro do pretérito integrou a exposição As construçōes de Brasília, realizada no Instituto Moreira Salles do Rio de Janeiro, entre abril e julho, ena Galeria de Arte do Sesi, em São Paulo, entre setembro janciro de 2010 coria de Heloisa Espada buscou revisitaros significados sambólicos de Brasíli e jan iro de Scheier,

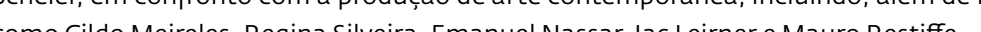
como Cildo Meireles, Regina Silveira, Emanuel Nassar, Jac Leirner e Mauro Restiffe. 


\section{O TEMPO VERBAL DE BRASÍLIA}

A obra de Rubens Mano futuro do pretérito, ${ }^{330}$ realizada em 2010, nos reporta de imediato ao tempo verbal da língua portuguesa, "futuro do pretérito do indicativo", que junta dois tempos opostos, o futuro e o passado, em uma única conjugação verbal. De acordo com a gramática, esse tempo enuncia, tanto na sua forma simples quanto na composta, a ocorrência de uma determinada ação ou fato condicionada a uma ação anterior, ou seja, sua efetivação é apenas hipotética. Um exemplo de conjugação na forma simples é: "eu ouviria aquela música todos os dias”. Na forma composta, ambas as ações se situam no tempo passado, isto é, pressupõe-se que as condições necessárias para a realização da ação ulterior não se cumpriram de fato. Por exemplo: "poderíamos ter comprado um sorvete, se eu não tivesse esquecido minha carteira".

Transposto para a obra de Mano sobre Brasília, a conotação desse tempo verbal indica que a leitura da cidade feita pelo artista é a de uma promessa não cumprida, ou ainda, de um projeto (moderno) de cidade que ainda não aconteceu plenamente, embora superado como ideologia (para muitos críticos, mesmo antes de sua inauguração). De certa forma, Brasília estaria fadada ao "fracasso", pois os princípios modernos que orientaram o plano piloto de Lucio Costa - qual seja, o do grau zero rumo ao futuro - foram refreados de início pela política nacionalista de JK e pela realidade subdesenvolvida do país, passando pelo retrocesso dos anos de chumbo da ditadura e, por fim, por seu congelamento como patrimônio tombado.

Mano não é o primeiro nem o único a ler Brasília dessa maneira. O título do trabalho reporta igualmente às palavras de Clarice Lispector citadas na epígrafe ("um futuro que aconteceu no passado"), e que definem as impressões da autora sobre a cidade visitada nos anos 1970. Dentre as infinitas leituras que se debruçam sobre a capital federal, as duas obras - uma literária, e a

330 Obra parcialmente disponivel em: <https://vimeo.com/30816029> (plano piloto) e <https://vimeo.com/26449526> (cidades-satélites). Acesso em 15 jan. 2018 outra artística - se avizinham por carregarem um paradoxo entre passado e futuro. No caso de Clarice, essa oposição é expressa na mistura de admiração e repulsa, de embriaguez e monotonia, aproximação e recuo, diante da apoteose de Brasília. Já em Rubens, a cidade moderna, afirmativa e "inviolável” é neutralizada por suas contradições históricas de origem, por certas marcas populares impressas no território e pelo desgaste de uso. Nessa oscilação estonteante, em ambas as aparições, as antinomias são inseparáveis. E é exatamente essa inseparabilidade que parece tornar a capital modernista tão intrigante.

A imagem de Brasília descrita por Clarice em 1974 enuncia poeticamente a contradição da cidade desde sua fundação: "Brasília é marcha nupcial. O noivo é um nordestino que come o bolo inteiro porque está com fome há várias gerações. A noiva é uma velha senhora viúva, rica e rabugenta”. ${ }^{331} \mathrm{Na}-$ queles anos em que escreveu sua crônica, o pano de fundo da ditadura acirraria ainda mais a impressão contraditória da autora: "Deste insólito casamento que assisti [...] saí derrotada pela violência da Marcha Nupcial que parece Marcha Militar e que mandou me casar também e eu não quero. Saí cheia de band-aids, [...] a nuca doendo e uma grande ferida doendo no coração". ${ }^{332}$ A ironia foi o meio encontrado por Lispector para descrever a cidade diante daquelas circunstâncias.

Já em Mano, cuja obra foi realizada em 2010, data em que Brasília celebrou seus 50 anos de existência, a crítica que se faz daquela vida citadina é bem mais sutil - mas, nem porisso, menos contundente (até porque, passadas cinco décadas, os princípios funcionalistas teriam, de certa forma, se acomodado aos usos e apropriações feitos deles). O artista soube, de um lado, costurar as antinomias do projeto da capital federal nos pequenos detalhes que emergiam dos lugares registrados, e, de outro, fazer as escolhas criteriosas quanto à forma de registrá-las. Estas incluíram a opção pelo formato

331 Ibidem, p. 6

332 Ibidem. 
videográfico, o posicionamento de câmera, o enquadramento de cenas e as transições entre elas. O próprio curso do tempo (da vida cotidiana da cidade) é reconstruído desaceleradamente, possibilitando uma apreensão maior dos detalhes mais sutis impressos no espaço urbano brasiliense e que destoam das suas feições modernas programáticas.

Os dois autores parecem deixar de lado, assim, a severidade dos julgamentos, recorrente nos discursos da crítica ao projeto moderno brasileiro que vigorou até os anos 1990. Uma das hipóteses plausíveis que se abre neste sentido (e que os aproxima) reside no fato de ambas as leituras da cidade partirem de uma perspectiva livre e “descomprometida”, que é própria da arte, em relação à função social que o projeto de Lucio Costa deveria cumprir (por meio de seus princípios modernos). Tal liberdade não implica que não sejam capazes de se posicionar criticamente, e é aí que está todo o interesse das obras.

Para a realização de futuro do pretérito, Mano se propôs a pesquisar a dimensão simbólica da espacialidade urbana de Brasília, partindo do pressuposto de que haveria uma correspondência "entre as formas de representação materializadas na arquitetura e os processos de produção de espaços 'ativados' pela sociedade”. ${ }^{333}$ Nas comemorações de seu cinquentenário, Brasília despontava como um estudo de caso excepcional na história do país, a ser investigado em seus aspectos simbólicos (do imaginário moderno), bem como da produção social do espaço, que incluiria os limites espaciais (e jurídicos) do plano piloto e suas subversões, as hierarquias sociais ali ensejadas e os interesses políticos de origem. O espaço de Brasília se apresentará, assim, por sua dupla existência: como dimensão reguladora de comportamentos e como dimensão criadora de comportamentos, em reação dialética à primeira.

Foi esse ponto de vista complexo sobre a cidade, espacial, social e temporal, que Rubens Mano escolheu para revisitar a modernidade de Brasília, e assim reatualizar o debate sobre suas contradições de origem. A obra deveria

333 Mano, Rubens. [Texto sobre o projeto da obra futuro do pretérito]. incessante [site do artista]. Disponivel em: <http://www.incessante.org/>. Acesso em 5 jan. 2018. impulsionar uma autoconsciência de Brasília, fazer com que ela pensasse a si mesma, não como uma imagem nem como um símbolo nacional moderno, mas como uma cidade que se refaz constantemente em seus viveres urbanos, mesmo que essas transformações no tempo e no espaço estejam restritas a pequenos detalhes dispersos pelo espaço público.

Portanto, é novamente na chave da produção (social) do espaço que Mano está interessado em investigar a vida urbana, agora voltando sua atenção para Brasília; no caso da capital federal, a trama é ainda mais complexa pelos temas cruzados que lhe são peculiares, quais sejam seu plano piloto funcionalista, seu isolamento no território nacional como estratégia política e seu tombamento que a transformou na maior área urbana preservada do mundo.

\section{CIDADE-PATRIMÔNIO}

Nada mais propício do que fazer essa reflexão sobre Brasília exatamente no ano em que a capital federal comemorava seu cinquentenário. A oportunidade se abriu ao artista a partir da possibilidade de concorrer ao Edital Arte e Patrimônio 2009, promovido pelo IPHAN, com patrocínio da Petrobras, e que integrava as ações do programa Brasil Arte Contemporânea do Ministério da Cultura. O edital tinha por objetivo fomentar:

[...] projetos que estabeleçam diálogos entre as artes visuais contemporâneas e o patrimônio artístico e histórico nacional, visando relacionar dois universos de referências culturais, por um lado, trabalhos artísticos e processos estéticos atuais e, por outro, os acervos, as tradições, as culturas e os sítios que estabelecem a memória do País.334

34 O texto do edital na íntegra está disponível em: <http://www.cultura.gov.br/noticias-destaques/-/asset_publisher/OiKX3XIRgiTn/content/edital-arte-e-patrimonio-2009-219657/10883/maximized $>$. Acesso em 3 jan. 2018. 
Não é objeto deste estudo o aprofundamento da noção de patrimônio artístico e histórico nacional. Parte-se do princípio de que a preservação tem sua importância para um país e sua história; porém, até que ponto ela seria a garantia da continuidade de sua memória?

No caso de Rubens, o que ressalta de sua escolha por Brasília como objeto tombado para ser o alvo de sua proposta para o edital é que o patrimônio cul tural envolve uma cidade inteira - lembrando Holston, "a maior área urbana tombada do mundo" e a "única cidade viva contemporânea tão preservada". Preservar uma cidade contemporânea não seria em si um contrassenso? Neste caso, preserva-se os princípios modernistas do plano piloto ou um projeto político de nação? Uma ambição arquitetônica ou um futuro que não aconteceu? A ideia do tombamento do plano piloto já não seria em si um paradoxo, visto que suas orientações corbusianas deveriam remetê-la permanentemente ao que está por vir? Sua vocação para o futuro não seria o seu maior valor? De modo geral, sua patrimonialização parecera mais preocupada com a preservação de uma ideia moderna, uma "cidade-modelo", cujos princípios ficaram obsoletos, do que como uma cidade "real", viva, própria de um espaço (urbano) praticado.

Rubens soube se apropriar desse debate e revisitar o patrimônio histórico e cultural de Brasília mediante suas fricções com o presente (como cidade habitada). Essa perspectiva foi associada às suas intenções iniciais de pesquisar a vida citadina da capital federal produzida pelo enfrentamento (e pela correspondência) entre as ações realizadas oficialmente nesses espaços urbanos e aquelas provocadas por outros agentes, em sua maioria anônimos.

\section{A FORMA HÍBRIDA}

Uma vez o projeto contemplado, Mano optou por construir sua pesquisa sobre a espacialidade urbana de Brasília a partir do registro videográfico da vida cotidiana. Ainda que tenha escolhido o vídeo como meio, valorizando a captação do tempo transcorrido no espaço da cidade, o artista atribuiu-lhe uma qualidade fotográfica - qual seja a do enquadramento da cena que man- tém fixo o posicionamento da câmera durante a captação. No texto escrito na ocasião da exposição no Museu da República, Laymert dos Santos analisa tal formato:

A fotografia videografada ao mesmo tempo é e não é fotografia e vídeo. Com a primeira [fotografia], ela compartilha, acima de tudo, o enquadramento, mas também a fixidez, a nitidez e outros atributos que remetem, em última instância, à suspensão do tempo e à imobilidade do espaço. Com o vídeo, ela compartilha o movimento, e o tempo na e da imagem, além da inserção do som, cuja presença vai afetar um outro sentido. ${ }^{335}$

De acordo com o crítico, a escolha híbrida, entre fotografia e vídeo, foi o dispositivo que o artista encontrou para enfrentar a trama complexa de diferentes tempos no tecido da cidade. Segundo Laymert, ele possibilitaria que "o espectador pudesse entrar no espaço próprio de Brasília e encontrar no espaço-tempo da imagem o espírito do lugar". ${ }^{336}$

Fotografar videografando implicava, assim, o uso da câmera estática por meio da qual obtinha-se o mesmo enquadramento durante a captação de imagens, valorizando-se com isso a passagem do tempo real em detrimento de um tempo decorrente do deslocamento do videografista. O congelamento da posição da câmera também significou em alguma medida um certo distanciamento autoral do artista (no sentido "artificial”), e conferiu um dado a mais de realidade ao movimento que se fazia dentro do quadro.

Em geral, Mano privilegiou um posicionamento frontal da câmera em relação ao campo visual, tendo a rua como primeiro plano. A proximidade com o nível do chão não só implicava que a câmera estivesse posicionada à altura natural dos olhos, como também evocava a tomada de posse da terra -

335 Santos, Laymert Garcia dos. Futuro do pretérito: do espaço moderno ao espírito do lugar. Finguerut, Silvia (org.). Artee Patrimônio 2007-2010 (n. 230). Brasília: Iphan, 2010 , p. 234 336 Ibidem, p. 232 


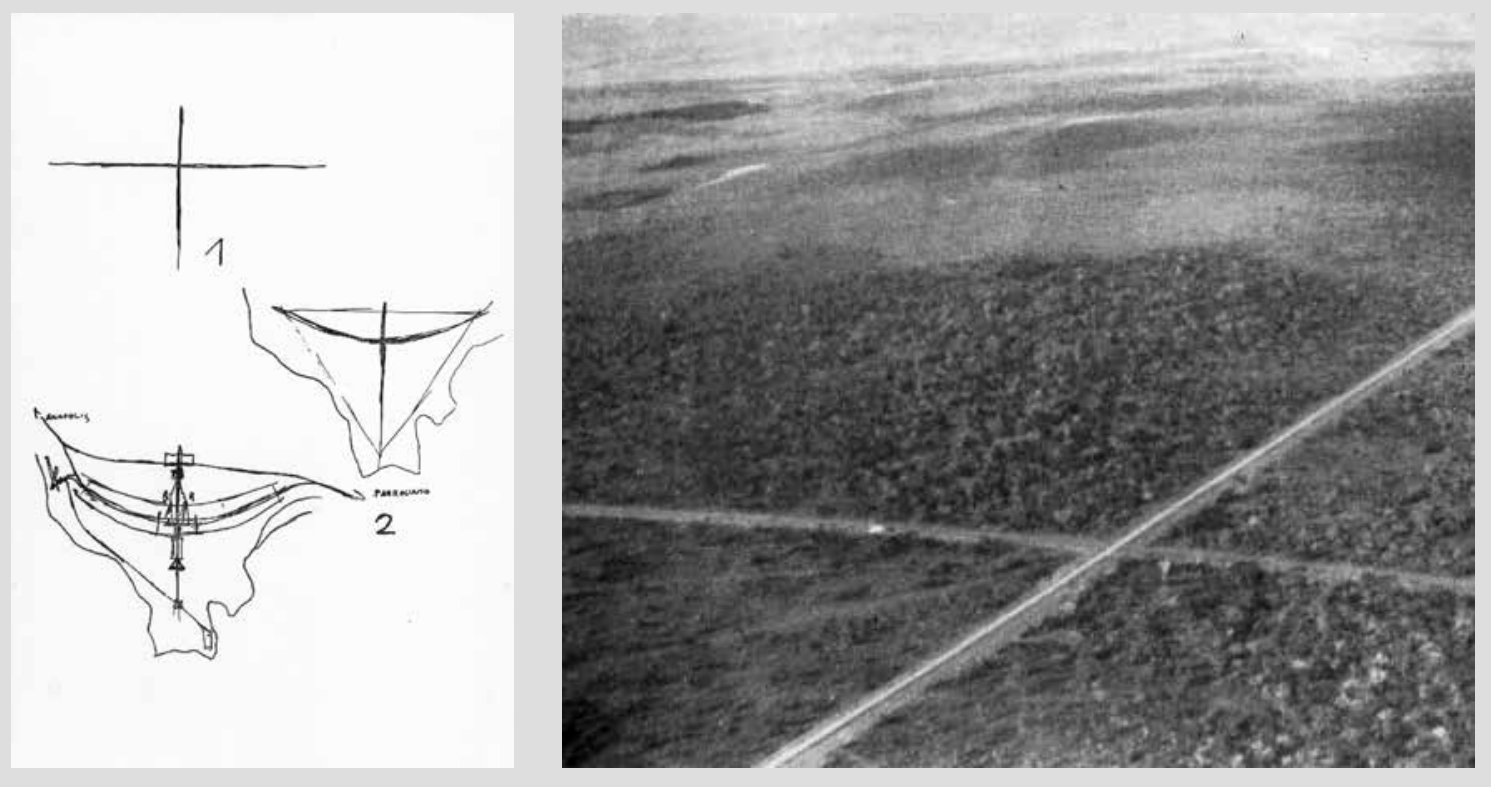

FIG. 33 Lucio Costa.

Croqui original que acompanhou 0 projeto para o Plano Piloto de Brasília, submetido ao concurso, 12.03.1957. Acervo Casa de Lucio Costa, RJ

(à esquerda) piloto de Brasília em construção. Acervo Fundação Oscar Niemeyer, RJ (à direita) daquilo a que Pedrosa se referia como o "espírito colonizador" do brasileiro, e que foi igualmente simbolizado por Lucio Costa no desenho sintético da cruz (figs. 33 e 34). (Ao final, o arquiteto optou por arquear levemente um dos eixos do desenho cruciforme para que se adequasse à topografia do terreno, adquirindo a aparência de um avião.)

Para a captação das imagens, o artista privilegiou o período da manhã e o final da tarde, quando a luz do sol não é tão intensa quanto ao meio-dia (preocupação que se intensifica sob o céu do cerrado, onde a luminosidade é ainda mais forte), e os elementos do quadro ficam menos contrastados. Além disso, boa parte das cenas tem o céu encoberto, meio acinzentado, fato que amenizaria possíveis efeitos contrastados de claro-escuro.

Como cidade fotogênica em si, dadas a singularidade de seus edifícios esculturais do eixo monumental e as grandes visuais com a paisagem do cerrado ao fundo, Brasília foi incansavelmente registrada em preto e branco. Ceralmente, tais fotografias p\&b, feitas com as "cores do concreto", 337 além de aludirem à materialidade da arquitetura brasileira, possuem um sentido nobre e pujante próprio dos anos de euforia do governo JK, percebido, por exemplo, nas fotografias de Marcel Gautherot. ${ }^{338}$ Já em futuro do pretérito, realizada décadas depois, a diversidade cromática da imagem assume também uma diversidade da natureza dos espaços vividos perseguida pelo artista.

Mano armou sua pesquisa sobre os viveres brasilienses em duas edições videográficas distintas. Uma representava os espaços urbanos no plano piloto e a outra, os espaços urbanos nas cidades-satélites. Tanto numa como noutra, o som é captado diretamente. Para a caracterização de ambas as "cidades", a escolha das cenas procurou seus espaços mais representativos: no caso do plano piloto, aparecem os edifícios do poder no eixo monumental, a rodoviária que representa o entroncamento das escalas monumental e residencial, as diferenças de cotas solucionadas pelas “tesourinhas”, as grandes
337 Martins, Sérgio. Futuro do pretérito [composto], ZUM - revista de fotografia, IMS, São Paulo, n. 6, abr. 2014, p. 121

338 Para uma apreciação da obra do fotógrafo, cf. Espada, op. cit., 2011 
vias de circulação automobilística da zona habitacional, o comércio local das superquadras, dentre outros; no caso das cidades-satélites, as qualidades dos espaços se repetem nas ruas de bairros residenciais, onde os prédios de gabarito baixo se alternam com casas unifamiliares, ambos protegidos freneticamente por grades, os carros aparecem em cima de calçadas e os espaços de lazer são indistintos da via pública.

Apesar de escolher edifícios representativos do eixo monumental, Mano procurou evitar um olhar oficial (do tipo cartão-postal), que reproduzisse a utopia forjada para o futuro promissor do país; esses edifícios públicos aparecem sempre em segundo plano, ora atrás de uma grande área de estacionamento vazio, ora atrás de um imenso gramado mal aparado.

O tempo das cenas e a transição entre elas também obedece a um rigor formal, próprio do artista. Com a câmera parada diante do campo visual, deixando o tempo transcorrer naturalmente no espaço urbano, Mano filma sequências longas o suficiente para que o observador as perceba em cada pequeno detalhe. Em geral, as cenas são aparentemente enfadonhas, de um tempo dilatado e lento ("Aqui é o lugar onde o espaço mais se parece com o tempo", diria Clarice). ${ }^{339}$ No caso do plano piloto, aos poucos surgem pequenos indícios que atritam a homogenia (moderna) do espaço: paredes descascadas, pichações, sujeiras nas calçadas, a grama que cresceu demais, alguém tentando pegar a manga do pé, um balanço improvisado na árvore.... ${ }^{340}$

Essa ambiguidade casa perfeitamente com a opção pela forma híbrida da fotografia videografada -, mas também reporta às origens antagônicas do processo de fundação da cidade, modernista e candanga. Por exemplo, numa das cenas tomadas no plano piloto, que enquadra um enorme edifício espelhado em segundo plano, o barulho constante de carro ao fundo mistura-se à música com sotaque nordestino, que vem provavelmente do quiosque destacado em primeiro plano, e que anima a monotonia daquele espaço de poder.

339 Lispector, Clarice. Brasília [1962], op. cit., p. 43

Prasilia se confunde com as cidades-satéltes". Espada, op. cit., 2011, p. 169
A preferência pela captação de imagens no despertar e no entardecer do dia implicou ao mesmo tempo a rara presença de pessoas nos contextos urbanos selecionados. ("Em Brasília, é sempre domingo", diria Clarice). ${ }^{341} \mathrm{~A}$ crítica de arte Thais Rivitti chega a apontar uma correspondência entre tal ausência de vitalidade nas ruas ao confinamento da vida pública de Brasília a quatro paredes. O que, no caso de uma capital federal, geraria um novo contrassenso entre as instâncias pública e privada. A ponto de, segundo Rivitti, ser inevitável "não pensar aqui na possibilidade de leitura da política nacional como farsa". ${ }^{342}$

É certo que futuro do pretérito apresenta uma cidade em crise, segrega$\mathrm{da}$, incapaz de atender minimamente às necessidades de seus habitantes. Apresenta as hierarquias de classe, as representações monumentais do poder, a rigidez de conduta que a cidade tenta impor aos moradores. ${ }^{343}$

Para a montagem final do trabalho no Museu da República, Rubens armou duas projeções audiovisuais programadas em loop, cujas edições tinham duração de 35 e 40 minutos, sem, contudo, haver uma sincronia entre elas. As imagens foram projetadas sobre dois painéis horizontais autoportantes de madeira medindo 2,75 × 4,90 m cada. As grandes dimensões dos suportes definiram uma escala projetiva condizente com um suposto envolvimento do corpo de quem as observa. A imagem projetada foi devidamente enquadrada nas dimensões do suporte, de modo que não deixasse qualquer resquício de moldura em volta. Esse artifício de montagem, associado às grandes dimensões do suporte, conferia à instalação audiovisual um sentido imersivo do público visitante na imagem projetada. À altura da observação da câmera o

341 Lispector, Clarice. Brasília esplendor, op. cit., p. 52

342 Rivitti, Thaís. Cidade tombada. Salzstein e Bandeira (orgs.). Historicidade e arte contemporânea: ensaios e conversas. São Paulo: ICCO/CEUMA-USP, 2012, p. 171

343 Ibidem, p. 168 
artista fez coincidir a altura do espectador, reforçando ainda mais o ambiente imersivo da obra.

No projeto expográfico, o posicionamento dos painéis foi estabelecido de tal modo que as projeções ficassem de costas uma para a outra, sendo impossível apreendê-las simultaneamente. O público era, assim, convidado a percorrer o espaço; neste percurso, entre um painel e outro, ele se deparava com as paredes curvas de Niemeyer, que o remetiam de volta às imagens das projeções. Entre a apreciação da cidade através da arquitetura (o espaço) e apreciação da arquitetura através da cidade vista pela lente de Mano (imagem de espaço), haveria uma alternância pela qual a cidade ecoava no museu e o museu ecoava na cidade videografada.

\section{PLANO PILOTO, CIDADES-SATÉLITES}

Graças à construção de um tempo dilatado conferida pela câmera estática, ao se deparar com as imagens de Brasília em futuro do pretérito o observador vai aos poucos percebendo a sutileza de detalhes que causam um certo ruído às imagens da cidade tomadas no espaço público aberto.

Nas captações feitas no plano piloto, esses pequenos detalhes ruidosos atritam a fotogenia da cidade-museu, como nas fotomontagens de Regina Silveira; porém, aqui as sobreposições não são artificiais, mas convivem sob tensão no mesmo espaço. A Brasília tombada vista por Mano não é aquela plenamente organizada, funcional, idealizada pelo urbanismo moderno da Carta de Atenas, mas uma cidade esvaziada, com pequenos indícios de obsolescência. Em boa parte dos quadros não há circulação de pessoas nas ruas, apenas um barulho constante do tráfego de automóveis ao fundo. Às vezes, ao murmúrio urbano sobrepõem-se sons de passarinhos.

No eixo-monumental, Mano dá um tratamento nada imponente às construções do poder e às grandes perspectivas do sentido longitudinal torre-lagoa. O artista persegue sempre um ponto de vista lateral, adjacente à frontalidade dos edifícios icônicos, o que dá às imagens do centro cívico, conforme apontou Espada, "um sentido cotidiano, distante dos eventos de caráter espetacular que costumam acontecer ali". ${ }^{344}$

Os símbolos arquitetônicos conhecidos do "eixão" aparecem em segundo plano. A forma icônica da Catedral, por exemplo, além se figurar parcialmente no quadro, por detrás de um edifício administrativo com sua fachada pichada, está "disfarçada” por uma lona (indícios de um restauro). O imponente edifício-sede da Procuradoria Ceral da República, uma composição de duas formas cilíndricas espelhadas, surge como um detalhe ao longe no meio de uma vasta área gramada com vegetação típica do cerrado.

Das poucas construções arquitetônicas destacadas em primeiro plano, as que aparecem nas imagens estão visivelmente ameaçadas pelas intempéries, com peças de revestimento faltando e infiltrações que interrompem o aspecto homogêneo da forma moderna (aquela que Tossin ironizou na limpeza diária do mármore que reveste o Palácio do Supremo Federal).

Ainda no plano piloto, há diversas tomadas de grandes vias de circulação expressa, geralmente vazias, bem como de entroncamentos de avenidas que interligam os eixos monumental, residencial e gregário; as áreas de estacionamentos se repetem, por vezes ocupadas por um carro velho, abandonado ou parcialmente destruído. Os poucos momentos em que sobressaem vias peatonais, estas são subterrâneas.

Numa dessas tomadas, já na zona residencial das superquadras, Mano registra o encontro entre a circulação de automóveis e a de pedestres organizado pelo desnível topográfico - uma marca do urbanismo funcional de Brasília, cujas reminiscências se encontram no ideal de aceleração moderna corbusiano. Ainda no mesmo quadro, notam-se algumas interferências na paisagem modernista, como sinais de pichação na passagem subterrânea e um poste de instalação elétrica isolado ao lado direito.

As cidades-satélites vistas por Rubens, contrariando as expectativas de uma morfologia irregular e de uma ocupação orgânica típicas das periferias

344 Espada, op. cit., 2011, p. 170. 
urbanas, apresentam uma certa vontade organizacional, resquícios de um espírito moderno brasiliense: quer pela repetição de certos elementos arquitetônicos dos edifícios icônicos de Niemeyer, quer por padrões urbanísticos que imitam a aparência regular do plano piloto.

Boa parte das tomadas realizada nas cidades-satélites é feita em áreas residenciais. Nelas, os edifícios multifamiliares seguem o gabarito baixo das superquadras, porém sem pilotis, e estão enfaticamente protegidos por grades de ferro. Em certas cenas, essas lâminas horizontais se intercalam a construções unifamiliares, de soluções construtivas populares. São poucas as vezes em que sobram áreas verdes no entorno residencial, e geralmente elas não chegam a configurar nem sequer uma praça. Em alguns ângulos propositalmente tomados pelo artista, percebe-se sequências de árvores idênticas enfileiradas em perspectiva, indicando que ali tem uma certa vontade projetiva de organizar a fronteira entre o espaço privado e o espaço público.

Duas marcas dessa coexistência entre o moderno e o popular figuram em primeiro plano nas cenas captadas por Mano: o Catetinho, conhecido como "Palácio de tábuas", concebido como edificação temporária em madeira para a residência oficial de JK durante o período de construção de Brasília; e o Museu Vivo da Memória Candanga, instalado no antigo Hospital Juscelino Kubitschek de Oliveira, nas proximidades do Núcleo Bandeirante. (Cabe lembrar que nem o Catetinho nem o Núcleo Bandeirante, ambos concebidos como provisórios, foram demolidos.)

Contrariamente, em outros momentos a oposição entre cidade oficial e cidade extra-oficial é gritante. Nas imagens fora do plano piloto, um dos elementos que mais chama a atenção são as grades. Elas aparecem tanto nas casas unifamiliares como nos térreos dos edifícios horizontais. No contexto das cidades-satélites, lembram que ali é "preciso" separar fisicamente o espaço público do privado. Ao cercear o fluxo de pessoas nos bairros residenciais, essas construções gradeadas lembram que a livre circulação idealizada por Lucio Costa nas zonas de vizinhança, e inspiradas pelo chão livre corbusiano, está longe de ser uma realidade daquele local, quanto mais uma utopia de seus moradores.
Assim, em futuro do pretérito percebe-se que a ambiguidade do fato de a Brasília tombada do plano piloto estar presente nos pequenos detalhes cotidianos das cidades-satélites, e vice-versa, corresponde à reversibilidade da montagem expográfica da obra, onde o local expositivo está impregnado da cidade registrada na obra e esta está impregnada da arquitetura daquele local.

\section{HABITAR O MODERNO HOJE}

No Brasil, a modernidade tardia forjada na construção de Brasília produziu imagens sedutoras de futuro, fazendo coincidir na mesma vontade criadora o projeto nacional desenvolvimentista idealizado por JK, a concretização de um autêntico protótipo da cidade funcional modernista e um espírito candango que abraçou o moderno como um "campo de experimento e risco" pelo qual era possível imaginar um futuro diferente. Ao longo dos anos, essas imagens sedutoras foram aos poucos sendo tensionadas: de um lado, pelas controvérsias ideológicas impressas na origem do projeto político da capital federal, tido como totalitário e segregador; de outro, pelas forças de resistência surgidas no próprio cotidiano da cidade vivenciadas no espaço público.

A Brasília vista pelo olhar de Rubens Mano expõe justamente esses dois lados, frutos do mesmo processo histórico, dissolvendo-os mutuamente, mas não no sentido de enfraquecê-los, e sim de modo a fazer perceber o quão intimamente ligados e interdependentes eles são.

É assim que futuro do pretérito surpreende as expectativas de um admirador de Brasília. Mano imprime no espaço-tempo da obra indícios de uma cidade iconoclasta (a civitas), que aparecem sempre ao fundo do cotidiano mais ordinário do plano piloto (urbs), relativizando a planificação e a funcionalidade de sua natureza moderna. O que seria a regra na oficialidade dos espaços preservados pelo tombamento - um aspecto organizado e grandioso - aparece levemente contaminado por improvisações, sujeiras e irregularidades. 
De modo inverso, nas tomadas feitas nas cidades-satélites, a expectativa de uma paisagem urbana precária - que se reproduz organicamente e de modo desordenado - é vez ou outra confrontada por enquadramentos com edifícios habitacionais de feições modernistas, elementos icônicos da arquitetura dispersos, bem como uma certa regularidade na organização da vizinhança, percebida na implantação dos edifícios no lote, ou mesmo numa sequência de canteiros verdes nas calçadas. Esses elementos dissonantes que se insinuam na paisagem das cidades-satélites e se inscrevem nas suas edificações revelam, segundo Laymert, "um esforço, frequentemente involuntário e impensado, de atualização e um desejo, talvez até mesmo inconsciente, de modernização, [...] um movimento de afirmação otimista, voltado para o futuro". ${ }^{345}$ Exatamente o que Holston salientara como o "espírito de Brasília" expresso nos viveres candango.

Opostamente, na edição das imagens do plano piloto, tais “interferências" trazem uma conotação mais "real" aos espaços públicos e abertos da cidade, e nesta justa medida transformam o espaço geométrico traçado pelo arquiteto em espaço praticado. A forma híbrida da fotografia videografada corrobora ainda mais nesse sentido, pois deixa que o tempo transcorrido atue na transformação daquele espaço que está congelado pela preservação. Nos detalhes mais sutis, o artista aponta que não se pode conter a vitalidade das ruas, mesmo numa cidade tombada como Brasília. Ao ler o espaço como um lugar, Rubens questiona até que ponto é possível preservar uma cidade condenada ao moderno, ainda em construção (lembrando que Brasília foi o primeiro ícone do século XX a entrar para a lista de Patrimônio Mundial da Unesco, em 1987).

Ao buscar investigar o tipo de vida citadina ensejada no espaço público da capital, o artista reconstrói pelo olhar videográfico um espaço-tempo que se recusa a ser passado, e que é ao mesmo tempo refém de um tempo promissor que não ocorreu e refém de um espaço congelado pela sua patrimonialização. Uma espécie de futuro do pretérito presentificado. É este o conflito tempo-

345 Santos, op. cit., p. 234 ral que a obra de Mano inscreve. (Curiosamente, essas mesmas impressões temporais conflitantes surgem na crônica de Clarice e confundem a autora ao longo de sua escrita: "Noto aqui um acontecimento que me espanta: estou escrevendo no passado, no presente e no futuro. Estarei sendo levitada? Brasília sofre de levitação". ${ }^{346}$

Em futuro do pretérito, por mais lento que seja o tempo transcorrido no espaço urbano - o que dá uma sensação de presentidade constante -, a obra insiste em apontar a possibilidade de transformação daquele espaço, não no sentido de um futuro promissor, mas de uma atuação de seus habitantes sobre o território, mesmo que mínima e sutil, capaz de "descongelar" Brasília no tempo e no espaço.

Ao longo das décadas, a construção de uma modernidade tardia no Brasil decantou um certo amolecimento de suas prerrogativas funcionalistas diante dos imperativos do ambiente subdesenvolvido. E, nesse sentido, a capacidade transformadora de certos moradores anônimos de Brasília surgem como um valor na obra de Mano.

As ambiguidades de Brasília que o artista percebe e faz conviver tanto no plano piloto quanto nas cidades-satélites poderiam ser atribuídas a uma nova crítica surgida nos últimos anos, que tem olhado para as mudanças de significado da esfera pública, expressa nos espaços abertos das cidades contemporâneas.

346 Lispector, Clarice. Brasilia esplendor, op cit, p. 46. 
imanente (2014) 
Em 2014, Mano foi convidado pelo curador Marcio Harum, então responsável pela Divisão de Artes Visuais do Centro Cultural São Paulo, a realizar uma exposição naquele centro cultural, programada para acontecer simultaneamente à mostra dos artistas selecionados do Programa de Exposições 2014. Como artista convidado, Rubens teria certa liberdade para escolher o local de sua proposição.

Na ocasião, Rubens relatara que há tempos aguardava uma oportunidade para propor um trabalho endereçado àquele lugar. O leitmotiv ele já tinha: as iniciais "RB" inscritas nos tijolos cerâmicos que forravam uma das paredes da biblioteca do CCSP. Servindo mais como elemento de revestimento do que como elemento estrutural, os tijolos foram assentados com a face interna voltada para a frente, de modo que era possível ler suas inscrições. No projeto original do edifício, inaugurado em 1982, seus autores - os arquitetos Eurico Prado Lopes e Luiz B. Telles - não mencionam o significado daquelas iniciais; sabe-se apenas que a dupla usou materiais de acabamento diversos com a intenção de criar "uma multiplicidade de elementos e variantes que pudessem promover interesses e emocionar o usuário", ${ }^{347}$ conforme escreveu Telles décadas mais tarde.

Na proposta encaminhada à curadoria, Rubens menciona os tijolos como disparador para a concepção do trabalho:

o trabalho está relacionado a um episódio associado à construção do Centro Cultural São Paulo [o erguimento de uma parede de tijolo à vista - presente em uma das laterais da biblioteca], e se articula ao redor de duas ações conexas [concomitantes e indissociáveis]. sendo que ambas se valem da ressignificação de um elemento básico relativo ao episódio citado: o tijolo cerâmico. esta parede - com aproximadamente 100 metros de comprimento - não tem função estrutural, e foi

347 Telles, Luiz B. Centro Cultural São Paulo: um projeto revisitado. Dissertaçao (Mestrado) - Faculdade de Arquitetura e Urbanismo da Universidade Presbiteriana Mackenzie, São Paulo, 2002, p. 297. 
A postura inquisitiva do artista aparentemente tinha desvendado o mistério pelo qual as iniciais "RB" prestavam uma homenagem ao ex-prefeito Reynaldo de Barros. Barros inaugurou o centro cultural no dia 13 de maio de 1982, dois dias antes de desligar-se da prefeitura para concorrer a governador do estado. Ao seu lado, estava o secretário municipal de cultura Mario Chamie. O poeta Chamie foi uma das figuras fundamentais na concepção do complexo cultural de escala metropolitana; segundo ele, o equipamento público deveria voltar-se a todos os munícipes, sem distinção de classe, idade ou gênero. ${ }^{349}$

Durante a pesquisa para o desenvolvimento do trabalho, Mano se deparou com o relato de uma antiga funcionária do CCSP; segundo esta, a ideia original dos arquitetos era compor a parede da biblioteca com referências a diversas olarias do entorno paulistano, formando um grande mosaico de iniciais. Ao final, como notou o artista, a parede levou as iniciais do prefeito Sua execução envolveu uma operação fabril de cerca de 50 mil tijolos marcados em alto relevo com as letras "RB".

348 Trecho do projeto encaminhado à curadoria do Centro Cultural São Paulo para a realização do conjunto de obras intitulado imanente.

349 Mario Chamie tinha 46 anos quando o prefeito o convidou a assumir o cargo. A frente da secretaria, buscou descentralizar a cultura na cidade, propondo, entre outros, o"Projeto Periferia", pelo qual inaugurou 13 pequenas bibliotecas em bairros distantes do centro, todas de escala singela e instaladas em imóveis simples. Sua gestão foi marcada pela vontade de mudar a política cultural até então vigente na cidade. Segundo ele, até a década de 1970 a cultura "alcançava basicamente um público restrito, de formação e escolaridade semierudita e universitária" Mario Chamie apud Serapiäo, Ferrestrito, Cefortua que o novo equipamento público deveria abrigar um programa mais democrático, como um centro que o novo equipan Olavo Setúbal.
A proposta de Rubens para a exposição no centro cultural foi intitulada imanente [adição_multiplicacão_divisão_subtração_], e se articulou em duas ações, ambas alimentadas pela descoberta das iniciais dos tijolos. Aqui, a complexidade dos projetos do artista ressurge em desdobramentos que envolvem diferentes ações, tais como visto nos vazadores, mas também em bueiro (como intervenção e como fotografia).

A primeira das açoes realizadas se constituiu numa intervenção física na parede da biblioteca, por meio da qual o artista substituiu um dos tijolos "RB" por um tijolo concebido por ele com a inscrição da palavra "imanente" em alto relevo (fig. 36). Segundo relato do artista, o tijolo "imanente" foi confeccionado na mesma olaria que tinha produzido os tijolos originais do Centro Cultural São Paulo (fig. 35). Até então, as iniciais de Reynaldo de Barros eram invisíveis aos olhos de funcionários e usuários do centro cultural; hoje, numa visita à biblioteca, é possível se deparar com o tijolo do artista incrustado no meio das cerca de 50 mil peças que revestem o talude paralelo à Rua Vergueiro ao longo de 200 metros.

Na proposta "arqueológica" do artista, certos espaços cifrados, apagados na memória coletiva da cidade, são desvelados. Por meio da intervenção na parede, constata-se que os domínios da vida privada, na figura do gestor municipal, acabaram por demarcar os desígnios públicos do projeto, sem que fossem expressamente assim declarados. Cabe recordar que o período que englobou a concepção arquitetônica do equipamento municipal, a partir de 1976, até sua efetivação como Centro Cultural São Paulo, inaugurado em 1982, tinha como pano de fundo a ditadura militar. Reynaldo de Barros havia conquistado o cargo de prefeito graças à indicação de Paulo Maluf, então governador do estado (ambos apoiavam o regime), e sua gestão foi considerada populista e demagógica, sofrendo dura oposição do movimento popular organizado.

Neste ponto, é preciso esclarecer que a origem da destinação da área para abrigar um equipamento municipal se deu na gestão anterior, durante a prefeitura de Olavo Setúbal. Logo após assumir a nomeação, no final 

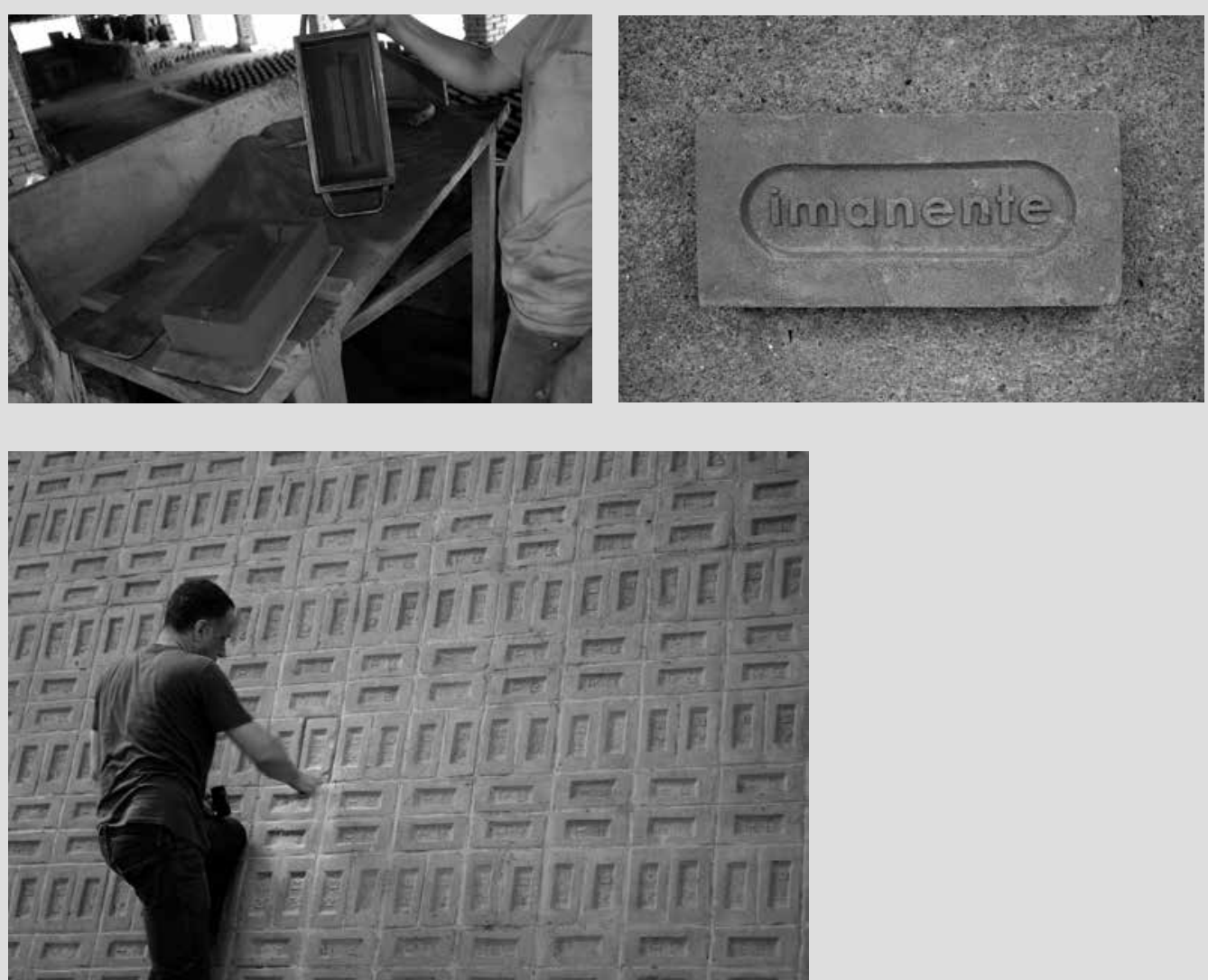

FIG. 35 Registro do processo de confecção do tijolo na olaria (acima à esquerda). Foto: Rubens Mano

FIG. 37 Rubens Mano durante a ação de substituição do tijolo "RB" pelo tijolo imanente.

FIG. 36 Registro do tijolo imanente na versão avermelhada (acima à direita). Foto: Rubens Mano de 1975, Setúbal se viu contrariado com os desígnios privados daquele lote público (seria uma medida muito impopular) e decidiu cancelar a construção de um complexo empresarial no terreno, localizado entre a avenida 23 de Maio e a Rua Vergueiro (a gleba era uma sobra do canteiro de obras da estação Vergueiro do metrô). O projeto tinha sido vencedor de um concurso promovido pelo prefeito que lhe antecedeu, Miguel Colassuono. Recém-empossado no cargo, Setúbal nomeou os engenheiros da Emurb para fazer um estudo de viabilidade para a construção de uma biblioteca naquele local; sob influência de Noemi do Val Penteado, diretora do Departamento de Bibliotecas Públicas da cidade, o prefeito tinha se sensibilizado com o problema de acondicionamento do acervo da Biblioteca Municipal Mário de Andrade, e resolveu dar outro destino à área: uma biblioteca para abrigar a seção de periódicos da BMMA.

Os técnicos da Emurb se reuniram com os bibliotecários da BMMA para pensar o programa do futuro equipamento e estabelecer as diretrizes do concurso; fizeram algumas visitas técnicas, inclusive em bibliotecas de bairro na Finlândia. A equipe contou ainda com a consultoria da Plae Arquitetura e Urbanismo, dirigida pelos jovens arquitetos Eurico Prado Lopes e Luiz B. Telles, especializados em resoluções de ambientes empresariais (principalmente em layouts e conforto ambiental). No início de 1976, a Emurb abriu concorrência pública e a Plae acabou vencedora. Durante a gestão Setúbal, a dupla de arquitetos projetou um edifício de quatro pavimentos para abrigar parte do acervo da BMMA, e que levaria o nome de Biblioteca Central de São Paulo. Porém, na gestão de Reynaldo de Barros, o secretário Mario Chamie considerou que o programa do equipamento público devia ser ampliado para receber um centro cultural multiuso, voltado a todas as idades e classes sociais. Por fim, o projeto foi adaptado para abrigar o atual Centro Cultural São Paulo. ${ }^{350}$ Conforme declararam seus autores, tanto a concepção do programa

350 O processo de designação da gleba pública municipal, e que atravessou três diferentes gestões, está descrito em detalhes no livro de Fernando Serapião. Cf. Serapião, op. cit. 
como o partido arquitetônico adotado tiveram fortes inspirações no então recém-inaugurado Centre Georges Pompidou, em Paris.

De volta à obra de Mano, o tijolo imanente criara um ruído no mosaico de iniciais e convocava o visitante a descobrir a historicidade daquele lugar, não apenas em seu vocábulo arquitetônico mas também na sua esfera pública. É como se o tempo tivesse embaçado a marca celebrativa da parede da edificação (que, em certa medida, funcionava como um monumento dissimulado) e tornado imagem sua densidade histórica. O trânsito entre as instâncias pública e privada, própria da vida urbana na cidade, é aqui apresentado não somente em seus aspectos físicos, mas em suas implicações políticas e dos interesses de poder envolvidos (é sabido que grande parte dos governantes querem imprimir a marca de sua gestão no território, como visto na escala federal, com a Brasília de JK; aqui, no exemplo municipal de Barros, o revelador é que nesse caso o gestor imprimiu uma marca pessoal nominal e fisicamente, como um gesto de autorreverência do poder, cujo prefeito impopular foi imposto pelo regime militar).

A substituição das iniciais pela palavra "imanente" não só anulava o gesto de autorreverência como deslocava o valor para a materialidade do elemento construtivo tijolo, produzido pelas olarias típicas da região do entorno da cidade (desde sua fundação, São Paulo já contava com pequenas olarias que fabricavam telhas de barro; geralmente se concentravam próximas ao rio Tietê, em regiões alagadiças, perto de sua matéria-prima).

De acordo com o Dicionário filosófico de André Comte-Sponville, é imanente "tudo o que é interior à consciência", "tudo o que faz parte do universo material". ${ }^{351}$ Num sentido clássico, é imanente "o que permanece em algo ou alguém". Ao designar o tijolo como "imanente", o artista desloca a atenção do monumento dissimulado para a materialidade do elemento construtivo e para o que ela carregaria como evidência histórica.
Indagado sobre o uso do termo "imanente" na exposição, Mano relata que o uso partiu de uma referência ao pensamento do filósofo Cilles Deleuze, elaborado nos termos de uma "utopia imanente". Segundo Peter Pál Pelbart, leitor do filósofo, "a utopia em Deleuze jamais remete a um tempo futuro e uma forma ideal. Designa antes o encontro entre o conceito e o meio presente, entre um movimento infinito e o que há de real aqui e agora, que o estado de coisas impedia de vir à tona". ${ }^{352} \mathrm{O}$ utopismo de Deleuze é imanente à medida que resiste a idealizações e se concentra na materialidade do real.

Em Mano, a palavra imanente adquire um caráter político às avessas ao negar o uso que se fez do tijolo como um elemento de autoenaltecimento à pessoa política de Barros. A substituição de códigos impressos na peça cerâmica ativaria, assim, a consciência daquele lócus, marcando-o sutilmente, sem alterar propriamente o contexto (lembrando as palavras de Lucy Lippard). Ela opera esteticamente a reconstrução das dimensões culturais e políticas do lugar.

A troca da peça foi feita pelo próprio artista (fig. 37), sinal de que Mano não abdicou do caráter performático de suas proposições (algo visto com recorrência nos trabalhos erráticos dos anos 1990). Durante a exposição, o vestígio da ação era fornecido por meio de uma câmera que captava o tijolo imanente e seu entorno, e transmitia a imagem em tempo real para um monitor montado em videowall, instalado na segunda parte da exposição do artista, no Piso Caio Graco. A opção pelo formato do videowall recuperava uma tecnologia da década de 1980, dos primórdios do vídeo, e de certa forma reconstituía imageticamente os anos de inauguração do CCSP, numa arqueologia imanente.

Ao lado dos monitores, Mano dispôs um conjunto de antigos tijolos de olarias do entorno paulistano, adquiridos pelo artista em desmanches de

352 "O exerćício imanente em Deleuze traça uma linha transversal na atualidade, nem de exterio-

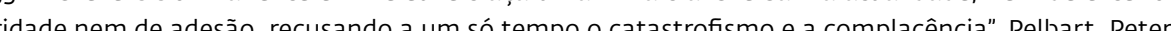

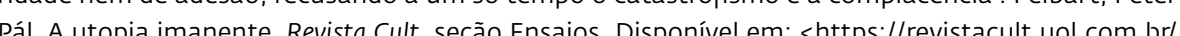
Pál. A utopia imanente, Revista Cult, seção Ensaios. Disp 
construção, cuja seleção e disposição no CCSP explorava a diversidade de iniciais e desenhos com os quais as peças eram tradicionalmente identificadas e recuperava um possível mosaico do que teria sido o projeto original dos arquitetos para revestir a parede da biblioteca.

\section{AS POLÍTICAS DO HABITAR}

A segunda ação, "concomitante e indissociável", nos termos do artista, aconteceu no Piso Caio Craco, no mesmo local onde o videowall e os tijolos antigos foram dispostos. Ali, Rubens reconstituiu as plantas das unidades habitacionais dos programas do governo federal Banco Nacional da Habitação (BNH) e Programa Minha Casa Minha Vida (PMCMV), utilizando-se de 3.700 tijolos imanentes. Na oportunidade, Mano expôs lado a lado os 50 anos que separam um do outro projeto político.

O BHN foi criado em 21 de agosto de 1964 e perdurou até 21 de novembro de 1986, abrangendo o auge e a decadência do regime militar que tinha sido imposto ao país a partir de 1964. Naquele ano, o lançamento de uma política brasileira de habitação em nível federal fazia parte do programa nacional desenvolvimentista do governo e respondia a várias demandas: rápido crescimento da população urbana, fruto da migração do campo; enorme déficit habitacional; surto inflacionário; e uma Lei do inquilinato desencorajadora. ${ }^{353}$

De outro lado, estava o recém-criado PMCMV, um dos maiores programas habitacionais em aporte de dinheiro jamais visto no país, e que foi instituído pelo governo Lula em 2009. Sem pretender tecer um estudo esmiuçado sobre as questões políticas, arquitetônicas e imobiliárias envolvidas em ambos os programas federais, o que é importante salientar para as análises acerca da proposição do artista é que ambas colaboraram na produção do es-

353 Banco Nacional da Habitação. BNH: avaliação e perspectivas. Rio de Janeiro: Secretaria de Divulgação do BNH, 1974, p.7. paço dos grandes núcleos urbanos do país, deixando que a iniciativa privada (empresas subsidiárias que coordenaram os empreendimentos) ditasse os modos de habitar de grande parte da população brasileira (maioria composta por aqueles que ganhavam até 11 salários mínimos). Mais preocupados em fazer dos investimentos um negócio lucrativo, as subsidiárias determinavam desde as dimensões da casa própria, e seus espaços internos; passando pelo percentual de unidades distribuídas para cada faixa de renda; até os locais onde os empreendimentos seriam construídos - geralmente longe do centro, em terrenos mais baratos e sem qualidade urbana que suprisse as necessidades do morar. 354

Rubens soube perceber a ocasião dos cinquenta anos que separavam a criação de um e de outro para confrontá-los fisicamente em seus aspectos políticos, ideológicos e construtivos. O artista elegeu a unidade de moradia de 37 metros quadrados, de ambos os programas, e reconstruiu suas plantas em escala 1:1. Os ambientes foram postos lado a lado, interseccionados por um dos seus cantos. As plantas volumétricas foram seccionadas a uma altura de Go centímetros, de tal forma que o visitante era capaz de apreendê-las integralmente na altura dos olhos. Todas as paredes foram erguidas com os tijolos imanente, sendo que a planta do BNH foi realizada com tijolos de tom avermelhado, dando um aspecto mais antigo, e a planta do PMCMV foi feita com tijolos claros.

354 Para uma análise mais precisa sobre os resultados da política habitacional do Banco Nacional de Habitação - BNH, cf. Maricato, Ermínia. Política habitacional no regime militar: do milagre brasileiro à crise econômica. Petrópolis/RJ: Vozes, 1987; Maricato, Hermínia. Habitação e cidade. São Paulo: Atual, 1997; Veras, Maura P. Bicudo e Bonduki, Nabil. Política habitacional e a luta pelo direito à habitação. Covre, Maria de Lourdes (org.). A cidadania que não temos. São Paulo: Brasiliense, 1986, pp. 40-72. Para uma aproximação sobre os significados e impactos do Programa Minha Casa Minha Vida - PMCMV cf Fix, Mariana e Arantes, Pedro. "Minha Casa Minha Vida": o pacote habitacional do Lula Correio do Cidadania, 30 set. 200 . Disponivel em: <http//www.correiocidadania com br/especiais/66-pacote-habidania, 30 set. 2009 . Disponive "Mrocote-habitacional/3580-31-07-2009-minha-casa-minha vida-o-pacote-habitacional-de-lula $>$. Acesso em 21 jan. 2018, Amore, Caio Santo; Shimbo, Lúcia Zanin, Cruz, Maria Beatrz (orgs.). M Mha casa... e a cidade? tal, 2015; Baravelli, José Eduardo. Trabalho e tecnologia no programa MCMV. São Paulo: Annablume, 2017. 
Em meio século, nota-se que muito pouco mudou em termos de tecnologia nos programas habitacionais: o tijolo artesanal e o sistema autoportante ainda orientam o processo construtivo; no programa, mantém-se a cartilha de sala, cozinha, 2 quartos e banheiro; quanto às dimensões, a área de 37 metros quadrados permanece como parâmetro de espaço doméstico mínimo passível de ser financiada pelo governo, voltado para atender a classe menos favorecida (abaixo de três salários mínimos).

Ao percorrer esses espaços domésticos, interseccionados na exposição de modo que o visitante caminhasse por um dentro do outro, a pouca alteração entre as duas unidades aparece na subdivisão dos espaços internos, no fluxo entre os cômodos dentro da casa e a proporção entre eles - por exemplo, a redução significativa dos corredores, diminuindo a transição entre os ambientes mais coletivos e os ambientes íntimos.

A problematização dos programas habitacionais na obra de Mano, por meio da experiência física e temporal do visitante ao percorrer os espaços, enfrenta as determinações políticas que regem a vida doméstica e, desse modo, retoma o equilíbrio de forças, permanentemente em jogo, entre o público e o privado. Em imanente, a substituição do tijolo e a reconstrução das plantas habitacionais nos incitam a refletir sobre suas dimensões políticas, para além das circunstâncias físicas, nas quais subjazem determinações sobre os modos de nos relacionarmos com os lugares e os modos de habitá-los - sejam eles públicos ou privados. 
Produzir um estudo interdisciplinar que de fato aproximasse os campos da arte, da arquitetura e do urbanismo sob a "síntese" da cidade e da vida urbana nas últimas décadas era um desejo há muito perseguido por mim na vida universitária, desde pelo menos a graduação. Com o desafio posto pelo estudo transdisciplinar e pela interlocução entre as práticas, a presente tese procurou estabelecer certas correspondências en tre uma vertente artística contemporânea - cujos fazeres se posicionam a partir de uma perspectiva contextualista e pressupõem o espaço como um constructo cultural - e a experiência urbana mais recente, decantada dos modos como a vida tem sido conformada pela sobreposição de uma nova condição urbana fragmentada sobre o tecido moderno da cidade industrial.

Desde o princípio da década de 1990, a cidade contemporânea vem operando a partir de duas dinâmicas distintas, uma real e outra virtual. No contexto da cidade de São Paulo - mas verificado também em muitos outros grandes centros urbanos - a experiência urbana implicou processos como a fragmentação do território, a desterritorialização dos lugares e a sensação de deslocalização do sujeito na cidade, que se acentuaram com o modus operandi específico paulistano, aquele que destrói e constrói incessantemente. Na capital paulistana, ao tecido urbano moderno incompleto sobrepôs-se bolhas de "cidade global", com centros de comando que operam suas trocas econômicas e simbólicas nas redes virtuais.

Nas últimas décadas, portanto, essa cidade foi aos poucos sendo tensionada, quer pela substituição de suas atividades econômicas industriais por atividades de serviço, quer pela incorporação de novos fatores que passam a determinar os modos de vida urbano - principalmente aqueles vindos da tecnologia. O fio condutor da relação arte/indústria que caracterizara a produção de arte local desde a década de 1950 expandiu-se sob várias formas e expressões da nova condição urbana, decantado pela experiência múltipla da cidade contemporânea.

O espaço da cidade passou a ser abarcado não só em suas dimensões físicas e materiais, mas também, e sobretudo, em suas dinâmicas sociais, culturais e políticas tecidas no e pelo território. As práticas artísticas agregaram cada vez mais camadas à medida que incluíram outros aspectos relevantes na 
produção do espaço da cidade. Elas foram apreendidas na chave de uma vertente contextualista renovada da arte.

Apesar da materialidade industrial ser ainda recorrente na produção artística local, ela já não se encerra mais nela mesma, como elemento físico e construtivo da paisagem urbana. Sua recorrência vem agregando cada vez mais camadas que buscam problematizar outras instâncias - históricas, culturais, sociais e políticas. As dinâmicas da cidade mudaram e as questões urbanas tornaram-se mais complexas.

Para este estudo ainda, foi fundamental perceber que o ambiente contemporâneo ensejado nos anos 1990 - com marcas de uma geração que passou a produzir sob a ordem da globalização da cidade e da cultura - carregava reminiscências da problemática urbana surgida na transição dos anos 1960 para os 1970, quando a lógica da produção industrial foi aos poucos substituída pela lógica da produção do espaço e a condição urbana passou a ser estruturante. Tal fato evidenciou ainda mais a importância de uma esfera de debate sobre a questão urbana atual.

Neste contexto, a produção do artista Rubens Mano surge em correspondência profícua com meus pressupostos teóricos acerca das transformações da cidade nas últimas décadas, especialmente aquelas verificadas em São Paulo. As leituras das obras aqui abordadas revelaram que a prática do artista tem se demonstrado atenta aos processos que a cidade vem sofrendo desde a passagem da década de 1980 à de 1990.

O embate exaustivo com poucas obras de Mano possibilitou extrair as evidências de suas inquietações (tanto urbanas quanto da própria esfera artística) e exemplificar procedimentos recorrentes na arte contemporânea em geral. Dentre elas, sobressaíram alguns aspectos: o atravessamento entre fotografia e arquitetura, espaço e imagem de espaço; o reposicionamento do objeto artístico sob o viés da transversalidade, como obra-arquitetura e como obra-urbanismo; a dialética recorrente entre espaço projetado e espaço praticado; a perspectiva do observador-perceptor na fruição artística enquanto experiência-obra; e a vontade de continuar a esgarçar as fronteiras entre o mundo da arte e o mundo extra-artístico.
Na prática artística de Mano, desde o início, evidenciou-se uma certa natureza nômade urbana, a partir da qual ele construiu um olhar (fotográfico) sobre a cidade. Essa vivência da cidade aos poucos vai apontando para um desejo de armar o trabalho de arte mais como experiência do que como objeto, tanto do ponto de vista do artista como do público. Ao longo da pesquisa, percebeu-se que essa experiência como obra pode se dar tanto no momento mesmo de sua realização (na duração do tempo do trabalho, a exemplo de detetor e vazadores) quanto como reminiscência (neste caso, projetada geralmente numa situação imersiva que abre espaço para a experiência do corpo do sujeito, a exemplo de futuro do pretérito, ou mesmo quando essa abertura é dada pelo campo visual da fotografia, como em casa verde).

O embate com o urbano em Rubens Mano também se faz presente em boa parte da produção brasileira contemporânea, e tem marcado o trabalho de diversos artistas mais recentemente, tais como Marcelo Cidade e Clarissa Tossin. Mano surge, assim, como um exemplo modelar de enfrentamento operado por certas práticas artísticas recentes diante das questões urbanas que vem transformando os modos do viver nas grandes cidades. Obviamente, isso não quer dizer que a qualidade da arte que vem sendo produzida a partir de São Paulo é determinada por motivações advindas da questão urbana. Há certamente outros assuntos que mobilizam o artista hoje - a exemplo da própria historiografia da arte, do embate com meios e materiais, das novas tecnologias, do sujeito e sua subjetividade, e assim por diante. Esta tese buscou evidenciar apenas um de muitos movimentos da arte contemporânea produzida no meio urbano, especialmente o paulistano; aquele que se mostrou mais intimamente interessado nas dinâmicas e nas contingências da experiência do meio urbano atual. 
apêndice 


\section{APROXIMAC̣ÕES ENTRE MANO E MATTA-CLARK}

Em 1969, quando Gordon Matta-Clark volta a morar em Nova York depois de passar uma temporada de estudos em Paris, onde seu pai residia, ${ }^{355}$ o Greenwich Village, bairro em que cresceu e que tradicionalmente era ocupado por imigrantes italianos, sofria um processo de gentrificação que vinha pondo abaixo boa parte do sul da ilha (o chamado Lower Manhattan), capitaneado pelo engenheiro Robert Moses. A rua onde morou, LaCuardia Place, passou a abrigar a University Village - um anexo do campus universitário da New York University com 3 torres de 30 andares. O bairro de infância do artista era mais um dos distritos que, nos anos 1960, foram assolados por uma avalanche de demolições promovidas pela administração da cidade com o intuito de abrir caminho para a construção de grandes eixos viários de circulação metropolitana, bem como para altos investimentos imobiliários e corporativos, a exemplo do World Trade Center.

Esse tipo de situação recorrente no contexto nova-iorquino daqueles anos, despertou um sentimento de indignação em Matta-Clark, o que o mobilizou a realizar uma série de proposições por ele intituladas "city-related works", dentre elas: o churrasco em baixo da Brooklyn Bridge oferecido aos moradoras de rua do entorno, em Pig Roast; a distribuição de oxigênio para a multidão da Wall Street, em Fresh Air Cart; e o restaurante Food, aberto no Soho em 1971, que oferecia trabalho e ponto de encontro aos artistas do bairro..$^{356}$ Dali em

355 Apesar de Gordon Matta-Clark não ser objeto de estudo desta tese, valeria pontuar que, no contexto biográfico do artista, seu pai - o pintor surrealista chileno Roberto Matta - havia trabalhado como desenhista por dois anos no escritório de Le Corbusier no final dos anos 1930. Provavelmente, tal fato teria influenciado a escolha universitária deste filho pela arquitetura.

356 Ainda neste periodo. Matta-Clark também se engajou num coletivo de performance, que usava difícios"vintages" como plataforma para suas ações. Estas geralmente diziam respeito à vida domés-

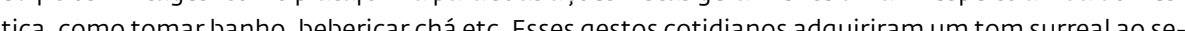

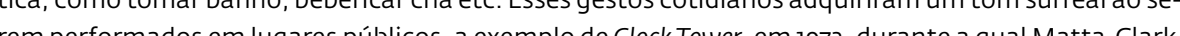
improvisou um banho de ducha no alto do edifício. Jenkins, op. cit., p. 53. 
diante viria uma sequência de intervençoes em resposta à transformação radical por que passava sua cidade natal, vivenciada intimamente pelo artista em seu cotidiano no bairro onde morava, o Soho. O forte caráter de resistência frente à política urbana vigente vinha, muitas vezes, acompanhado de um sentido comunitário, pelo qual o artista dava relevo à rua como espaço político, de reunião e de conflitos.

Além do Soho, o bairro periférico do Bronx foi outra importante região que sofrera os processos de reurbanização da cidade, atraindo a pulsão ativis ta de Matta-Clark em direção a novas proposições artísticas que viriam expor a situação de abandono e decadência gerada pelos novos interesses imobiliários em voga. As memórias nova-iorquinas do filósofo Marshall Berman sobre a época ajudam a ilustrar a situação degradante do Bronx, resultante das intervenções de Moses para abrir grandes vias de ligação entre bairros periféricos e o centro da ilha:

Por dez anos, do final dos anos 1950 ao início dos 6o, o centro do Bronx foi martelado, dinamitado e derrubado. Meus amigos e eu [...] fiscalizaríamos o andamento das obras - as enormes escavadeiras e motoniveladoras, as estacas de madeira e de aço, as centenas de trabalhadores com seus capacetes de cores variadas, os gigantescos guindastes que se debruçavam bem acima dos telhados mais altos do Bronx, os tremeres e explosões provocados pela dinamite, as rochas recém-descobertas, ásperas e pontiagudas, os panoramas de desolação estendendo-se por quilômetros e quilômetros, até onde a vista pudesse alcançar, a leste e oeste - para nos maravilharmos ao ver nosso bairro comum e agradável transformado em sublimes, espetaculares ruínas. ${ }^{35}$

O Bronx, onde cresci, tornou-se mesmo uma senha internacional para o acúmulo de pesadelos urbanos de nossa época: drogas, quadri-

357 Berman, Marshall. Tudo o que é sólido se desmancha no ar. São Paulo: Companhia das Letras, 2007, p. 342. lhas, incêndios propositais, assassinatos, terror, milhares de prédios abandonados, bairros transformados em detritos e em vastidões de tijolos espalhados. ${ }^{358}$

Foi ali que, no início dos anos 1970, Matta-Clark perseguiu terrenos baldios e edifícios abandonados para realizar suas primeiras "intervenções subtrativas", em reação ao esfacelamento do cotidiano, de espaços de integração e de lazer públicos, e às transformações da paisagem do bairro. As subtrações de arquitetura consistiram em uma série de cortes e dissecações intituladas Bronx Pieces (figs. 8 e 9). As "peças" eram pedaços de pisos e paredes resultantes de um corte que seccionava edifícios degradados. Segundo o artista, tratava-se de "pequenos troços de edifícios retirados de casas abandonadas deixadas abertas para perambuladores, cachorros e para mim". ${ }^{359}$ A ilegalidade da ação corroborava para o alerta sobre a decadência urbana daquele lugar.

Como pontuado no Capítulo 2, a partir do estudo da obra casa verde, o interesse por espaços residuais não se restringe aos anos 1990 de Rubens Mano. Entre as décadas de 1960 e 1970, os chamados terrains vagues converteram-se em "fascinantes pontos de atenção, nos indícios mais solventes para poder se referir à cidade", lembrando o comentário de Ignasi de Solá-Morales sobre o período. As intensas transformações urbanas daquelas décadas mudaram radicalmente a paisagem da cidade, cujos processos foram vivenciados "na pele" por Matta-Clark e imediatamente postos em questão pelo artista.

Ainda que as distâncias no tempo e no espaço coloquem ambos os artistas em situações distintas, é possível aproximá-los de antemão sob dois aspectos: o interesse por situações urbanas residuais produzidas pela modernidade e a opção por uma prática construtiva subtrativa, em que se enfrenta o real a partir de suas estratégias operativas intrínsecas.

358 Ibidem, p. 340

359 "[...] discrete chunks of buildings taken from abandoned tenements left open to derelicts and stray dogs and to me". Matta-Clark apud Jenkins, op. cit., p. 54 
Ouanto ao primeiro aspecto, as situaçoes encontradas por Mano no território paulistano foram impulsionadas pelo modus operandi singular, mas não exclusivo, da cidade de São Paulo - uma lógica que, como apontado ao longo da tese, tem se propagado no tempo desde a fundação da capital paulista (o chamado binômio demolição-construção). Soma-se a isso o contexto específico dos anos 1990, no qual as políticas de urbanização para a cidade foram pautadas pelas operações urbanas que, conforme expôs Lucrécia Ferrara, destruíram bairros inteiros em favor da ocupação do solo e da venda de potencial construtivo, deixando de lado a requalificação desses lugares em termos urbanísticos e de sociabilidade. Já em Matta-Clark, suas intervenções reagiam a um processo de reconfiguração urbana localizado na Nova York dos anos 1960 e 1970, na esteira da crise do urbanismo modernista. Elas eram uma verdadeira "crítica em ação" frente à gentrificação, que incluiu o questionamento do modelo de vida privatizada do subúrbio norte-americano, que isolou a vida comunitária em grandes complexos habitacionais nas franjas da cidade, destruindo o sentido de reunião do espaço público (a rua).

O segundo aspecto está ligado ao aporte construtivo da formação em Arquitetura e Urbanismo que constitui ambas as práticas, e que de certa forma foi reelaborado a partir do campo artístico por meio de uma operação subtrativa, que subverte a lógica edificante da profissão (uma "não-arquitetura"). Dentro desses referenciais de formação comuns, o embate com a cidade em Mano foi impulsionado pela experiência urbana nômade cujas origens remontam à atividade jornalística associada à aprendizagem do olhar pela fotografia, pelo qual o artista percebeu certos movimentos recorrentes na lógica de produção do espaço na cidade paulistana. No caso de Matta-Clark, mobilizado pelo forte impacto da política urbana de Moses, vivenciada no dia a dia do artista, suas intervenções foram facilitadas por um sólido conhecimento arquitetural e por habilidades construtivas consideráveis que se somaram ao valor do corpo em ação - sendo este último fruto da experiência com o coletivo performático, sob influência da dança de Trisha Brown.
O enfrentamento da questão da gentrificação urbana promovida pela destruição de bairros inteiros e vivenciada pelo artista culminou em 1974 com sua obra paradigmática Splitting (figs. 38 e 39), na qual cortou uma casa verticalmente, separando-a em duas partes. A edificação localizava-se na periferia de Englewood, na outra margem do rio Hudson, em Nova Jersey, e correspondia a uma zona em transformação igualmente destinada a novos empreendimentos imobiliários. Na ocasião, o sobrado foi cedido pela amiga e proprietária Holly Solomon (sua futura galerista), cujo marido adquirira o imóvel como investimento (diga-se de passagem, o mesmo bairro onde a família já possuía negócios). Por trás da intervenção de Matta-Clark, guardava-se o velho processo de degradação de bairros periféricos e sua "modernização".

As implicacões urbanas despertadas pela obra são trazidas à tona por Pamela Lee na seguinte passagem:

[A propriedade] foi adquirida não pelo edifício, uma coisa banal num bairro decrépito, mas pelo valor de seu lote. A compra de Solomon, na verdade, era um ato do estado real de especulação dramatizado pelo destino do próprio edifício: a casa seria demolida em alguns meses. Portanto, Matta-Clark tinha permissão para usar o imóvel, mas com o conhecimento de que seu trabalho duraria pouco tempo. ${ }^{360}$

Em depoimento citado por Lee, o artista considera que o seccionamento vertical em "splitting the house" era tudo menos ilusionista ("trata-se de uma atividade física direta, e não de fazer associações com nada que não esteja ali"). ${ }^{361}$ Entretanto, de acordo com as análises da historiadora, além da resistência à destruição de bairros inteiros, a intervenção de Matta-Clark trazia reminiscências do modo de vida suburbano norte-americano (o chamado "mito

360 Lee, op. cit., p. 11

67 "It's all about a direct physical activity, and not about making associations with anything outside it". Matta-Clark apud ibidem, p. 21. 

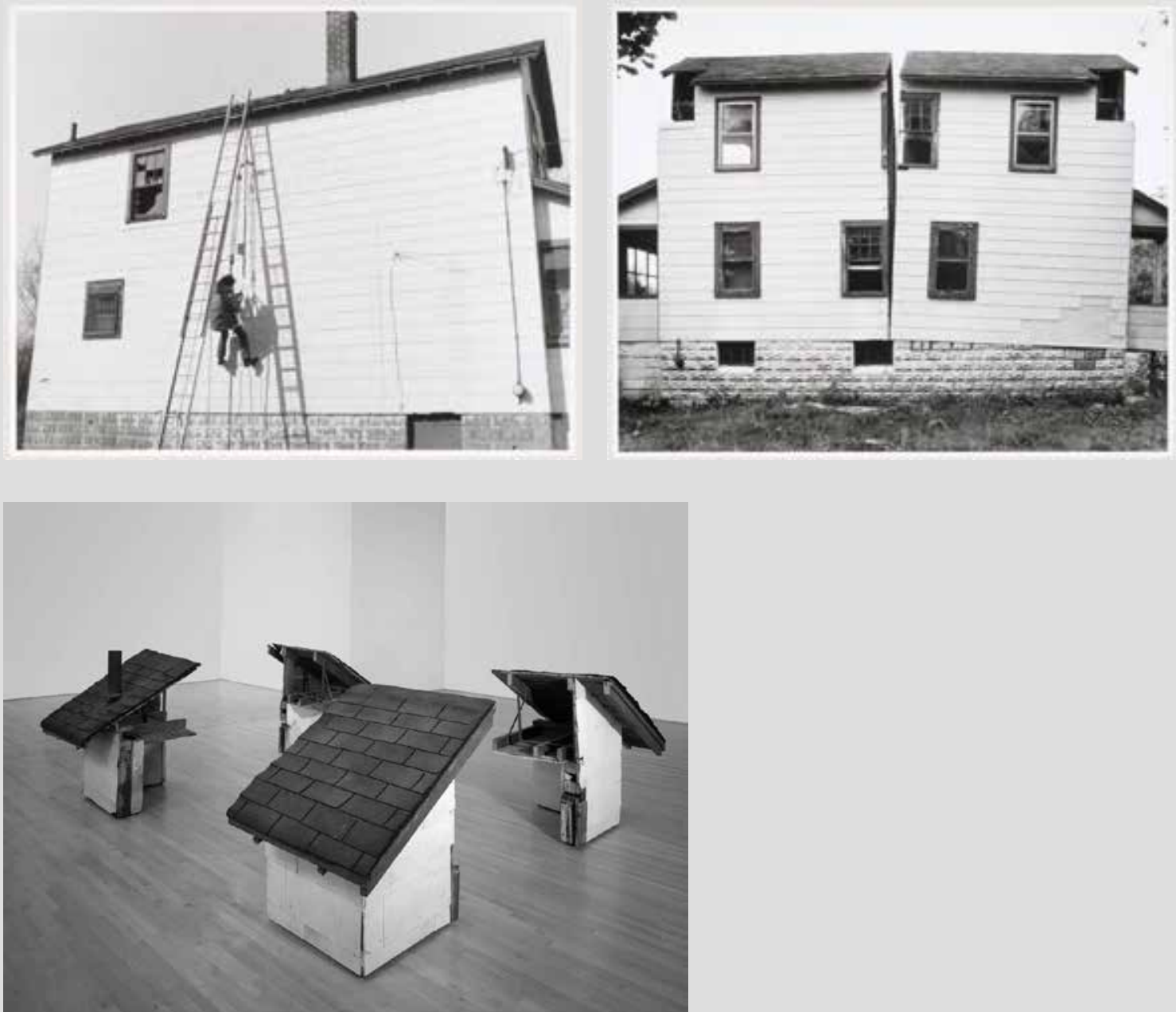

FIGS. 38-39 Gordon Matta-Clark. Splitting, 1974

Fotografia, impressão em gelatina de prata, 40,64 × 50,8 cm

Coleção San Francisco Museum

of Modern Art (Cortesia The Estate of

Gordon Matta-Clark)
FIG. 40 Gordon Matta-Clark. Splitting: Four Corners, 1974 Instalação com fragmentos de construção, dimensões variáveis. Coleção San Francisco Museum of Modern Art. da casa do subúrbio"), ${ }^{362}$ fundado pela urbanização massiva construída nas bordas da cidade, ou, mais precisamente, fora dela. Em Splitting, o modo de vida suburbano - nomeado por Lee como "o culto à privacidade" -, em crise, foi transgredido pelo artista antes que a máquina avassaladora do mercado imobiliário o eliminasse por completo.

A problemática da vida urbana produzida nos subúrbios norte-americanos pelo planejamento moderno em grande escala já tinha vindo à tona em 1967 com Robert Smithson. Em Os monumentos de Passaic, o artista atribuiu a essa lógica planificadora o erguimento de uma cidade já em ruína. A cartografia das bordas metropolitanas realizada por Smithson fez emergir resquícios de um projeto moderno de cidade em crise nesses subúrbios, estressando a condição urbana desses espaços, sem tradição nem qualidade. No entanto, diferentemente de Smithson (que publicou sua cartografia numa revista de arte especializada), a estratégia de atuação do jovem artista nova-iorquino passava ao largo do circuito institucionalizado das galerias, dedicando-se a explorar espaços alternativos e trabalhar para além do mercado.

De volta à Splitting, o artista desdobrou sua intervenção realizada corporalmente sob o edifício em outras temporalidades, passando pelos registros fotográficos e fílmicos do processo até a seleção de partes da casa que sobraram da demolição, transformadas em "escultura" com Four Corners (fig. 40). A condição impermanente de suas intervenções impunha com frequência sua dilatação para além do acontecimento da ação, elaborada sob outros formatos.

A natureza desdobrável de suas proposições - quer seja em diferentes partes (intervenção, fotografia...), ou em outras obras (esculturas, filmes...) também apareceu com frequência na produção de Mano aqui estudada, tais

362 Para a autora, "em virtude de sua distância da cidade, a privacidade do subúrbio parecia literalizar essa ideia Eolarsuburbano condens temporal de uma esfera pública agora considerada degradada por influências de classe, étnica espaço("by virtue of its distance from the city, the privacy of the suburb would seem to literalize this concit. And the oubur from a public sphere now regarded as debased by class, ethnic, and racial influences"). Lee, op. cit., p. 23. 
como em bueiro, detetor e vazadores. Em ambos os artistas, é como se suas proposições envolvessem tantas camadas que elas pediriam diferentes formali zações em diferentes tempos, a fim de dar vazão à trama de relações percebidas e que constituem a complexidade da produção do espaço a partir dos anos 1960 (ou mais precisamente, a partir do ponto crítico lefebvriano). Mesmo os registros, se tomados simplesmente como documentos, ainda assim produzem um estranhamento pela energia latente que resguardam dos processos ali condensados e vivenciados no espaço da cidade.

No caso das intervenções de Matta-Clark, a preocupação em registrar em filme o acontecimento de sua ação-performance vinha acompanhada de uma ampla campanha de divulgação da ocorrência da obra por parte do artista. Diferentemente de Mano, eram raras as vezes em que Matta-Clark não anunciava publicamente suas intervenções anarquitetônicas, principalmente aquelas que tinham um caráter performático sobre as edificações e envolviam dias de trabalho no canteiro, tal como em Englewood.

A série buiding-cuts, decantada de Splitting, passou a ser, sem dúvida, a marca registrada do artista, pela qual ficou conhecido internacionalmente, tanto por sua radicalidade quanto pela escala monumental perseguida dali em diante. Um dos grandes destaques dessa fase é Conical Intersect (figs. 10 e 41 a 46), intervenção realizada em 1975 para a Bienal Jovem de Paris.

\section{PARIS, SÃO PAULO}

Guardada as devidas proporções, a operação subtrativa de casa verde, proposta por Rubens Mano, pode ser aproximada aos building-cuts de Matta-Clark, especialmente àqueles em que o artista nova-iorquino produz um atravessamento luminoso nos edifícios, tal como em Conical Intersect. A correspondência pode ser feita sob vários aspectos. Há procedimentos análogos operados por Mano desde as negociações necessárias para se encontrar um edifício e intervir neste, passando pelas ações subtrativas, até os registros produzidos ao final, fotográficos ou fílmicos. Em casa verde, foram meses buscando a dispo- nibilidade de uma empresa de demolição e a melhor situação edificada para realizar a ação. Em Conical Intersect, foram meses de conversa com o grupo de curadores da Bienal de Paris para a qual o artista tinha sido convidado.

Inicialmente, a Bienal havia prometido à Matta-Clark um espaço de 30 metros quadrados, mas logo em seguida seus organizadores retrocederam, oferecendo apenas paredes do espaço museológico suficientes para expor uma documentação sobre a obra do artista. A partir daí, Matta-Clark passou a contar com o apoio do seu galerista em Nova York, Holly Solomon, da jovem marchand parisiense Gerald Piltzer e de Nina Felshin, curadora e ativista, responsável à época pelo andamento dos projetos dos artistas estadunidenses na mostra. Juntos, eles conseguiram pressionar a instituição para encontrar um novo lugar para a participação do artista, fora do museu. Meses depois, no dia 24 de setembro, a Société d'Économie Mixte (SEMAH), responsável pela renovação do bairro de Les Halles, contatou o artista e o autorizou oficialmente a trabalhar com um assistente num edifício que seria demolido em breve, situado na rua Beaubourg (fig. 41)..$^{363}$

O endereço era mais que propício para o ativismo anarquitetônico de Matta-Clark: uma construção abandonada em frente ao canteiro de obras do futuro "gigante metálico" Centre Georges Pompidou, projetado por Renzo Piano (fig. 42). A oferta, na verdade, consistia em dois sobrados geminados datados do século XVI, sem qualidades que "valessem" sua preservação. O conjunto arquitetônico era uma das últimas construções a serem varridas do bairro para ceder lugar ao novo Les Halles, que fazia parte do projeto político modernizante de De Gaulle para a capital parisiense. O artista teria até o dia 1o de outubro para fazer sua obra, ou seja, duas semanas; depois disso, os sobrados seriam postos abaixo pela SEMAH. ${ }^{364}$

Durante aquelas semanas, Matta-Clark e dois assistentes trabalharam no projeto e execução de cortes circulares que rasgariam paredes, pisos e tetos

363 Jenkins, op. cit. p. 7 . 364 lbidem. 


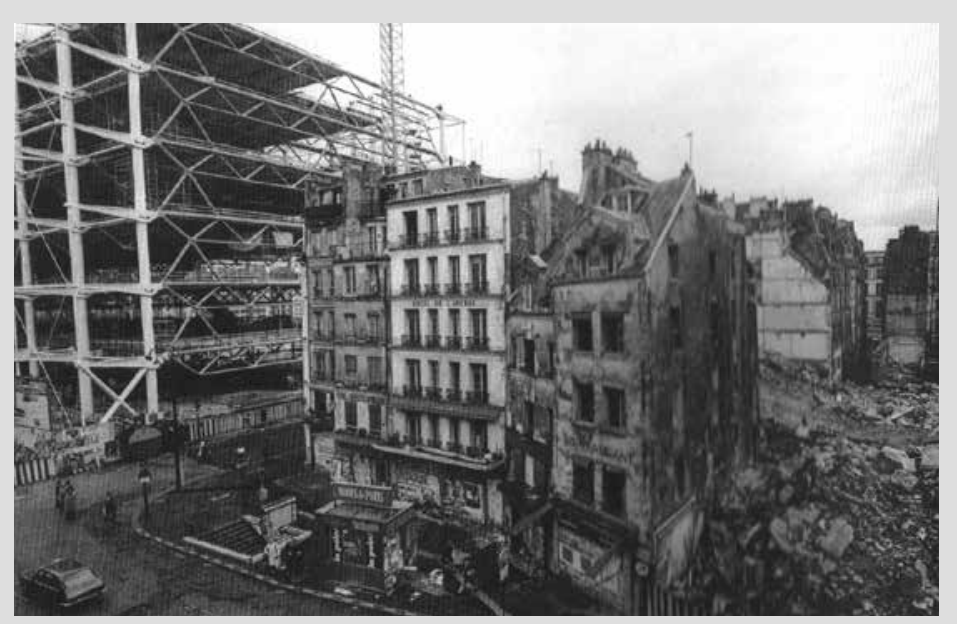

do conjunto edificado, a partir da fachada principal da rua em direção ao interior da construção (figs. 10 e 43). Desde Bronx Floors, passando por Splitting, a execução dos trabalhos era feita engenhosamente pelas mãos do artista, envolvido de corpo e alma na realização da obra (figs. 45 e 46).

Tal envolvimento corporal de Matta-Clark em suas intervenções arquitetônicas foi igualmente interpretado por Corinne Diserens nos termos de uma performance:

Desafiando as leis da gravidade e cristalizando a proposição de uma energia vertical, Matta-Clark, de serra na mão, propôs com os recortes de Bronx Floors e depois com os magníficos "building-cuts" (cortes de edifícios) um ato próximo daquele de Trisha Brown. ${ }^{365}$

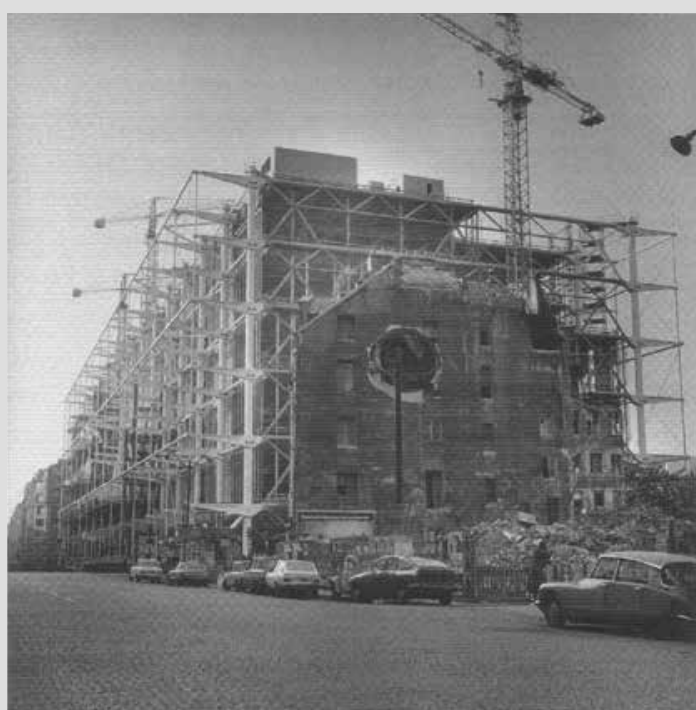

Aqui, a curadora se refere às performances de Brown nas quais os corpos dos dançarinos se deslocam obliquamente em relação ao plano horizontal do chão, desafiando a distribuição do peso, a força que impede que eles caiam (gravidade) e a inversão do nível "zero" do chão.

As semanas heroicas trabalhadas no canteiro ${ }^{366}$ ininterruptamente construíram uma espiral em contração, cujos círculos sequenciais iam de 4 a 2 metros de diâmetro no sentido de direção de fora para dentro (figs. 43 e 44). A construção subtrativa da espiral em contração possibilitou uma visão do interior do edifício ao transeunte que por ali passasse - tanto o passante incidental quanto aquele que vinha especialmente para ver a intervenção. A luz deveria vir desses buracos escavados pelo artista nas empenas dos edifícios, cujo resultado aproximava-se a uma "dramatização

FIG. 41 Vista do local antes da intervenção de Matta-Clark no edifício, rua Beaubourg 27-29, Paris (acima) Foto: Marc Petitjean
FIG. 42 Gordon Matta-Clark. Conical Intersect, 1975 Intervenção em edificação, rua Beaubourg 27-29, com o Centre Georges Pompidou em construção ao fundo, Les Halles, Paris (abaixo)
365 Diserens, Corinne. O filme arquitetônico de Matta-Clark, Revista Tropico, 7 maio 2002. Disponivel em: <http://p.php.uol.com.br/tropico/html/textos/1095,1.shl>. Acesso em 25 set. 2017.

366 Nos últimos dias da excucão de Conical Intersect, com o trabalho quase finalizado, Matta-Clark 366 Nos Ullimos dias da exala-Clark cedeu

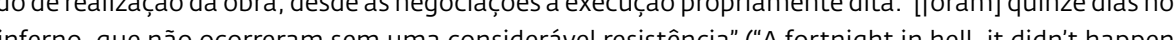
inferno, que nao oconeram sem una considerável resistencia" ('A fortnight in hell, it didn't happen without considerable resistance"). Matta-Clark apud Jenkins, op. cit., p. 1. 

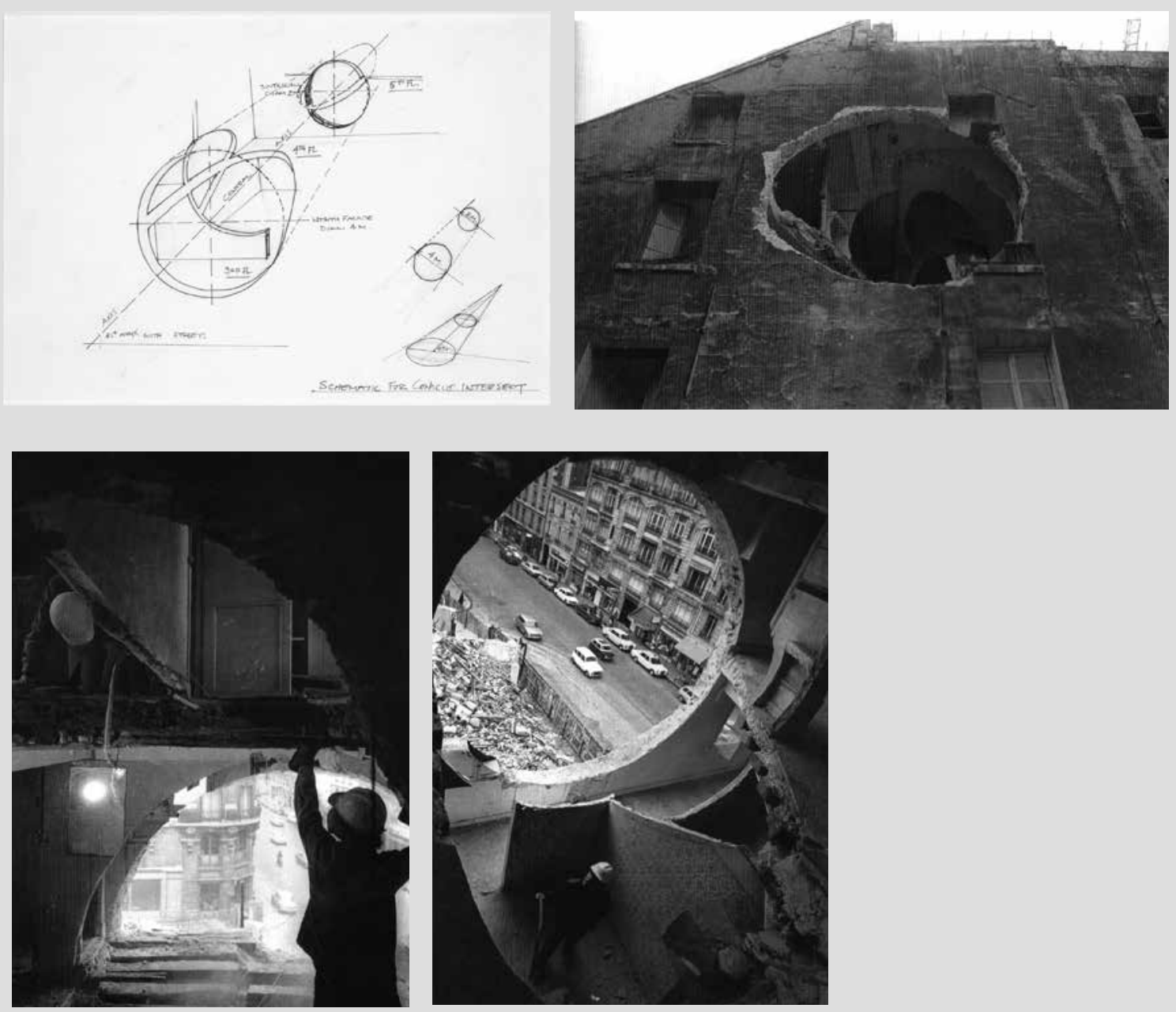

FIG. 43 Gordon Matta-Clark. Projeto

para Conical Intersect, 1975

Grafite e nanquim s/ papel,

$19 \times 26,3 \mathrm{~cm}$ (acima à esquerda)

Coleção Centre Canadien

d'Architecture, Montréal

FIG. 44 Gordon Matta-Clark.

Conical Intersect, 1975

(acima à direita)

Foto: Marc Petitjean
FIGS. 45-46 Gordon Matta-Clark. Conical Intersect, 1975 Imagens do processo de construção da obra, com $o$ artista trabalhando. Fotos: Marc Petitjean

sem atores", em que o artista combinava um ambiente estrutural à performance urbana.

A luz é outro ponto de interesse para se tecer comparações entre a prática de Mano e a de Matta-Clark. Se no caso brasileiro, ela tem origem no aprendizado da fotografia e sua condição de realização (mesmo que precariamente, tal como visto em detetor), no caso norte-americano ela deriva do interesse pelo cinema, cuja natureza temporal é um valor evidente, impresso igualmente na influência da dança em sua obra. O cinema, em Matta-Clark, corresponderia à possibilidade de se vivenciar a experiência (espaço-temporal) urbana grandiosa, tal como em suas intervenções monumentais.

De acordo com Diserens, "a câmera acompanhou constantemente Gordon Matta-Clark em sua produção artística de 1971 a 1977, como uma ferramenta de exploração e experimentação que revela seu pensamento". ${ }^{367} \mathrm{O}$ artista chegou a produzir cerca de 20 filmes que, segundo a curadora, podem ser agrupados em três categorias: os filmes-performances do início; os filmes e vídeos de textura, em que explora o tecido urbano, a arquitetura e a paisagem de ruína; e os filmes de recortes de edifícios, em que documenta as fendas abertas na arquitetura. Neste último caso, donde inclui-se Conical Intersect, os filmes testemunham a importância da luz para Matta-Clark, ao documentar a exposição das entranhas desses edifícios ao fato luminoso, salientando o drama urbano de seus desaparecimentos.

Um fator determinante para o artista norte-americano na realização de suas intervenções era o grau com que elas podiam transformar a estrutura em "ato de comunicação", ao abalar as paredes e fundações do edifício, metáfora comum para representar o mundo. Em Conical Intersect, a intervenção parodiava a própria demolição em processo no bairro repaginado do futuro Pompidou.

Conical Intersect se destaca como a pedra fundamental na trajetória do artista que trouxe uma criticidade presciente nos domínios da arquite- 
tura moderna, que abraçou as dimensões sociais e políticas da arte e que tentou expandir os contextos e o significado de uma prática pós-minimalista. ${ }^{368}$

A complexidade de uma obra como Conical Intersect expunha ao mesmo tempo: a gentrificação de bairros tradicionais parisienses tomados como "obsoletos" na Paris de De Gaule (um movimento que se verificava não só na Europa, mas nas Américas); o ativismo político de boa parte de suas ações anarquitetônicas (contribuindo para o debate do período sobre a incorporação das preocupações contextuais, sociais e comunitárias na prática artística); as negociações necessárias para realizar o trabalho estabelecidas com as pessoas envolvidas e o caráter performático de suas atuações (por meio do qual o artista mergulhava de corpo e alma no trabalho) associado a uma "obra-ato", ou o que o artista chamou de "ato de comunicação".

Analogamente, casa verde (mas também bueiro) envolveu múltiplas camadas sobre o contexto, expostas sob diferentes formalizações e temporalidades - desde a percepção sobre aquele fenômeno na cidade; passando pela habilidade em negociar com a empresa de demolição a fim de alterar os processos; os deslocamentos perceptivos promovidos pela nova "construção" negativa, transversal ao fluxo normal das ruas; e finalmente o desbordamento da ação em fotografia, e tudo o que ela implicou na estruturação formal do campo imagético para a (re)construção do espaço. Em casa verde, Rubens acentua a visibilidade dos processos históricos e dialéticos de construção e reconstrução da cidade de São Paulo, bem como das práticas urbanas contemporâneas, ao construir uma obra- arquitetura capaz de alterar os processos em curso e dar relevo a um outro lugar dentro daquele lugar.

Ambos os artistas subvertem a lógica dos processos de apagamento na cidade - por meio de uma construção negativa - e fazem ver uma cidade não

368 "It is Conical Intersect that stands as the corner-stone in a career that brought a prescient criticality
to the realm of modern architecture, embraced the social and political dimensions of art and attempted to expand the contexts and significance of a post-Minimalist practice". Jenkins, op. cit., pp. 2-3. visível em suas dimensões arquitetônicas, históricas e políticas. A fotografia e o filme passam a ser o trânsito entre a memória daquele lugar (arquitetura) e transformação da paisagem (cidade). Para se falar da cidade e suas dinâmicas, tomar de assalto o lugar e intervir neste de forma a ressignificá-lo espacial, temporal e esteticamente, a arte aqui prescinde dos rótulos publicizantes comumente adotados. A obra imprime a vibração do acontecimento artístico transgressor da lógica urbana moderna e permite que a performance do artista se propague para além do tempo e do lugar em que se dá. 
referências bibliográficas - 


\section{ESTUDOS GERAIS E URBANOS}

AMORE, Caio Santo; SHIMBO, Lúcia Zanin; CRUZ, Maria Beatriz (orgs.). Minha casa...e a cidade?: avaliação do programa minha casa minha vida em seis estados brasileiros. Rio de Janeiro: Letra Capital, 2015. (CD-ROM)

ARANTES, Otília B. F. Olugar da arquitetura depois dos modernos. São Paulo: Edusp, 1995.

. Urbanismo em fim de linha e outros estudos sobre o colapso da modernização arquitetônica. São Paulo: Edusp, 2001.

. Berlime Barcelona: duas imagens estratégicas. São Paulo: Annablume, 2012.

ARGAN, Giulio Carlo. História da arte como história da cidade [1ª edição 1989]. São Paulo: Martins Fontes, 1998.

ARROYO, Julio. Bordas e espaço público. Fronteiras internas na cidade contemporânea, Arquitextos, São Paulo, ano 7, n. 081.02, Vitruvius, fev. 2007. Disponível em: <http:// www.vitruvius.com.br/revistas/read/arquitextos/07.081/269>. Acesso em 2 dez. 2017.

AUCÉ, Marc. Não-lugares: introdução a uma antropologia da supermodernidade. Campinas: Papirus, 1994.

AUMONT, Jacques. A imagem. Campinas/SP: Papirus, 1993. (Ofício de Arte e Forma) AZEVEDO, Ricardo Marques de. Metrópole: abstração. São Paulo: Perspectiva, 2006.

BANCO NACIONAL DA HABITACÃO. BNH: avaliação e perspectivas. Rio de Janeiro: Secretaria de Divulgação do BNH, 1974.

BARONE, Ana Claudia Castilho. Team 10: arquitetura como crítica. Dissertação (Mestrado em História e Fundamentos da Arquitetura e do Urbanismo) - Faculdade de Arquitetura e Urbanismo FAU-USP, São Paulo, 2000.

BAUDELAIRE, Charles. O público moderno e a fotografia (Carta ao sr. diretor da Revue française sobre o Salão de 1859) [20 jun. 1859]. Tradução de Ronaldo Entler. Disponível em: <http://www.entler.com.br/textos/baudelaire2.html>. Acesso em 10 jan. 2017. (Original em francês publicado em Études Photographiques, Paris: Société Francaise de Photographie, n. VI, maio 1999, pp. 22-32

BENJAMIN, Walter. Charles Baudelaire: um lírico no auge do capitalismo. São Paulo: Brasiliense, 1989.

Magia e técnica, arte e política: ensaios sobre literatura e história da cultura/Walter Benjamin. São Paulo: Brasiliense, 1994. (Obras escolhidas, v. 1) 
Rua de mão única. São Paulo: Brasiliense, 1995. (Obras escolhidas, v. 2)

BENSE, Max. Inteligência brasileira - Brasília [1965/2009]. XAVIER, Alberto e KATINSKY, Julio (orgs.). Brasília: antologia crítica. São Paulo: Cosac Naify, 2012, pp. 102-107.

BERMAN, Marshall. Tudo queésólido se desmancha no ar: a aventura da modernidade. São Paulo: Companhia das Letras, 2007.

BOLLE, Willi. Fisionomia da metrópole: representação da história em Walter Benjamin. São Paulo: Edusp, 1994

BUCCI, Angelo. São Paulo, razões da arquitetura: da dissolução dos edifícios e de como atravessar paredes. São Paulo: Romano Guerra, 2010.

CAMPOS, Candido Malta; GAMA, Lúcia Helena; SACCHETTA, Vladimir (orgs.). São Paulo, metrópole em trânsito: percursos urbanos e culturais. São Paulo: Senac, 2014.

Carta de Atenas. Atenas: IV CIAM, 1933. Disponível em: <http://portal.iphan.gov.br/ uploads/ckfinder/arquivos/Carta\%2ode\%20Atenas\%201933.pdf>. Acesso em 20 dez. 2017.

CASTELLS, Manuel. A sociedade em rede. São Paulo: Paz e Terra, 1999.

CERTEAU, Michel de. A invenção do cotidiano. Petrópolis/RJ: Vozes, 1994.

CHOAY, Françoise. Brasília - uma capital pré-fabricada [1959]. XAVIER, Alberto e KATINSKY, Julio (orgs.). Brasîlia: antologia crítica. São Paulo: Cosac Naify, 2012, pp. 60-65. COMTE-SPONVILLE, André. Dicionário filosófico. São Paulo: WMF Martins Fontes, 2011. COSTA, Lucio. Lucio Costa: registro de uma vivência. São Paulo: Empresa das Artes, 1995.

CURI, Fernanda. 60 anos do Parque Ibirapuera, Blog da Bienal, 20 ago. 2014. Disponível em: <http://www.bienal.org.br/post.php?i=1089>. Acesso em 31 out. 2017.

FERRARA, Lucrécia D’Aléssio. A estratégia dos signos: linguagem, espaço, ambiente urbano. São Paulo: Perspectiva, 1981

São Paulo, Brasil: da imagem local à identidade global. SOUZA, Maria Adélia Aparecida de et. al. (orgs.). Metrópole e globalização: conhecendo a cidade de São Paulo. São Paulo: Cedesp, 1999, pp. 42-56.

FELDMAN, Sarah. Patrimônio cultural e a dimensão metropolitana. CYMBALISTA, Renato; FELDMAN, Sarah; KÜHL, Beatriz (orgs.). Patrimônio cultural: memória e intervenções urbanas. São Paulo: Fapesp/Annablume, 2017, pp. 225-230.

FICHER, Sylvia. Edifícios altos no Brasil, Espaço \& Debates, n. 37, 1994, pp. 61-76.
Algumas Brasílias [2000]. XAVIER, Alberto e KATINSKY, Julio (orgs .). Brasîia: antologia crítica. São Paulo: Cosac Naify, 2012, pp. 360-367.

FIX, Mariana e ARANTES, Pedro. "Minha Casa Minha Vida": o pacote habitacional do Lula, Correio da Cidadania, 30 set. 2009. Disponível em: <http://www.correiocidadania.com.br/especiais/66-pacote-habitacional/3580-31-07-2009-minha-casa-minha-vida-o-pacote-habitacional-de-lula>. Acesso em 21 jan. 2018.

GONÇALVES, Lisbeth Rebollo (coord.). São Paulo imaginado. Textos de Amália F. de Lemos, Cristina Freire, Francisco C. Scarlato, João Batista Neto e Mariza Bertoli. Bogotá: PROLAM/Convenio Andrés Bello, 2006.

GORELIK, Adrián. Museu da modernidade [2007]. XAVIER, Alberto e KATINSKY, Julio (orgs.). Brasîlia: antologia crítica. São Paulo: Cosac Naify, 2012, pp. 411-419.

HARVEY, David. A crise. O enigma do capital. São Paulo: Boitempo, 2011, pp. 9-40.

. A liberdade da cidade, Urbania, n. 3, São Paulo, 2008, pp. 11-17.

. Condição pós-moderna: uma pesquisa sobre as origens da mudança cultural. São Paulo: Edições Loyola, 1993.

HEIDEGGER, Martin. Construir, habitar, pensar. Ensaios e conferências. Petrópolis/RJ: Vozes, 2001, pp. 124-141.

HOLSTON, James. Libertem o espírito de Brasília [1989/2010]. XAVIER, Alberto e KATINSKY, Julio (orgs.). Brasília: antologia crítica. São Paulo: Cosac Naify, 2012, pp. 306-312

JACOBS, Jane. Morte e vida de grandes cidades. São Paulo: Martins Fontes, 2011.

JACOUES, Paola Berenstein e JEUDY, Henri Pierre (orgs.). Corpos e cenários urbanos: territórios urbanos e políticas culturais. Salvador: EDUFBA/PPG-AU/FAUFBA, 2006.

JAMESON, Fredric. A virada cultural: reflexões sobre o pós-modernismo. Rio de Janeiro: Civilização Brasileira, 2006.

. Pós-modernismo: a lógica cultural do capitalismo tardio. São Paulo: Ática, 1997.

. Pós-modernidade e sociedade de consumo, Novos Estudos, Cebrap, São Paulo, n. 12, pp. 16-26, jun. 1985

KOOLHAAS, Rem. Nova York delirante. São Paulo: Cosac Naify, 2008.

. Trêst textos sobre a cidade. Barcelona: Custavo Gili, 2010.

LAVALLE, Adrián Gurza. As dimensões constitutivas do espaço público: uma aborda- 
gem pré-teórica para lidar com a teoria, Espaço @ Debates, São Paulo, vol. 25, n. 46, pp. 33-44, jan./jul. 2005.

LEFĖBVRE, Henri. A revolução urbana. Belo Horizonte: Editora UFMG, 1999.

O direito à cidade. São Paulo: Editora Documentos, 1969.

. O fim da história. Lisboa: Dom Quixote, 1981.

. La Produccion del Espacio, Papers: revista de sociologia, Universitat Autònoma de Barcelona, n. 3, pp. 219-229, 1974.

. L'Urbain. Le Retour de la dialetique: 12 mots clés pour le monde moderne. Paris: Messidor/Editions Sociales, 1986, pp. 159-171.

LIMA, Zeuler. Enclaves globais em São Paulo: urbanização sem urbanismo?, Arquitextos, São Paulo, ano 5, n. 059.02, Vitruvius, abr. 2005. Disponível em: <http://www. vitruvius.com.br/revistas/read/arquitextos/05.059/471>. Acesso em $29 \mathrm{dez} .2017$.

LISPECTOR, Clarice. Para não esquecer: crônicas. Rio de Janeiro: Rocco, 1999.

MAFFESOLI, Michel. Sobre o nomadismo: vagabundagens pós-modernas. Rio de Janeiro: Record, 2001.

MARICATO, Hermínia. Habitação e cidade. São Paulo: Atual, 1997.

Política habitacional no regime militar: do milagre brasileiro à crise econômica. Petrópolis/RJ: Vozes, 1987.

MONGIN, Olivier. A condição urbana: a cidade na era da globalização. São Paulo: Estação Liberdade, 2009

NOBRE, Ana Luiza. Max Bense: mobilidade e inteligência brasileira, Arquitextos, São Paulo, ano 14, n. 167.01, Vitruvius, abr. 2014. Disponível em: <http://vitruvius.com. br/revistas/read/arquitextos/14.167/5181>. Acesso em 5 jan. 2018.

NELBITT, Kate (org.). Uma nova agenda para a arquitetura. São Paulo: Cosac Naify, 2016.

PAVIANI, Aldo et. al. (orgs.). Brasília 50 anos: da capital à metrópole. Brasília: Editora UnB, 2010.

PEDROSA, Mário. Arquitetura: ensaios críticos. Organização Guilherme Wisnik, São Paulo: Cosac Naify, 2015

PELBART, Peter Pál. A utopia imanente, Revista Cult, seção Ensaios. Disponível em: <https://revistacult.uol.com.br/home/a-utopia-imanente/>. Acesso em 2 out. 2017.

ROSALEN, Raquel. A concepção do espaço (e a contraconcepção), situações urbanas,
Cadernos de Pós-graduação, IA-Unicamp, Campinas, v, 2, n, 2, pp. 80-85, 1998.

SALES, Marta Maria Lagreca de. Territórios de intermediação: uma hipótese para a análise e o projeto da cidade contemporânea. Tese (Doutorado em História e Fundamentos da Arquitetura e do Urbanismo) - Faculdade de Arquitetura e Urbanismo FAU-USP, São Paulo, 2008.

SANTOS, Milton. A natureza do espaço: técnica e tempo, razão e emoção. São Paulo: Edusp, 2014. (Coleção Milton Santos, 1)

SARLO, Beatriz. A cidadevista: mercadorias e cultura urbana. São Paulo: Martins Fontes, 2014. (Coleção Cidades)

SASSEN, Saskia. The Clobal City: New York, London, Tokyo. Nova Jersey: Princeton University Press, 1991.

SECCHI, Bernardo. Primeira lição de urbanismo. São Paulo: Perspectiva, 2006.

SERAPIÃO, Fernando. Centro Cultural São Paulo: espaço e vida. São Paulo: Monolito, 2012.

SIMMEL, George. A metrópole e a vida mental [1902]. VELHO, Otávio Guilherme (org.). O Fenômeno urbano. Rio de Janeiro: Editora Zahar, 1979, p. 11-25.

SOLÀ-MORALES, Ignasi de. Terrain vague, ArchDaily Brasil, ํo mar. 2012. Disponível em: <http://www.archdaily.com.br/br/o1-35567/terrain-vague-ignasi-de-sola-morales>. Acesso em 5 out. 2017.

SOLNIT. Rebecca. Wanderlust: A History of Walking. Nova York: Penguin, 2001.

SOUSA, Rosangela Silva. Uma investigação sobre as teorias da cidade mundial, cidade global, cidade pós-moderna e sua relação com a cidade de São Paulo. Dissertação (Mestrado em Geografia Humana) - Faculdade de Filosofia, Letras e Ciências Humanas - FFLCH-USP, São Paulo, 2008.

TELLES, Luiz B. Centro Cultural São Paulo: um projeto revisitado. Dissertação (Mestrado) Faculdade de Arquitetura e Urbanismo da Universidade Presbiteriana Mackenzie, São Paulo, 2002.

TELLES, Sophia da Silva. Brasília - O desenho da superfície [1989]. XAVIER, Alberto e KATINSKY, Julio (orgs.). Brasília: antologia crítica. São Paulo: Cosac Naify, 2012, pp. 326-330.

VAN EYCK, Aldo. Is Architecture Going to Reconcile Basic Values? NEUMAN, Oscar (ed.). CIAM'59 in Otterlo. Londres: Alec Tiranti, 1961, pp. 27-28.

VERAS, Maura P. Bicudo e BONDUKI, Nabil. Política habitacional e a luta pelo direito à habitação. COVRE, Maria de Lourdes (org.). A cidadania que não temos. São Paulo: 
Brasiliense, 1986, pp. 40-72.

WENDERS, Wim. A paisagem urbana, Revista do Patrimônio Histórico e Artístico Nacional, Rio de Janeiro, n. 23, pp. 181-19o, 1994.

ZWEIC, Stefan. Brasil, um país do futuro [1ª edição 1941]. Rio de Janeiro: José Olympio Editora, 2006

\section{ARTE MODERNA E CONTEMPORÂNEA}

AMARAL, Aracy A. Textos do Trópico de Capricórnio: artigos e ensaios (1980-2005). São Paulo: Editora 34, 2006. (Vol. 3: Bienais e artistas contemporâneos no Brasil)

ARANTES, Otília B. F. Depois das vanguardas, Arte em revista (Pós-moderno), ano 5, n. 7 . p. 5-25, ago. 1983.

ARTE/CIDADE, 1. Arte/Cidade: cidade sem janelas. Exposição no antigo Matadouro Municipal de São Paulo. Texto de Nelson Brissac Peixoto. São Paulo: Secretaria de Estado da Cultura/Editora Marca D’Água, 1994. (Catálogo de exposição)

ARTE/CIDADE, 2. Arte/Cidade: a cidade e seus fluxos. Exposição no centro de São Paulo. Texto de Nelson Brissac Peixoto. São Paulo: Secretaria de Estado da Cultura/Editora Marca D’Água, 1994. (Catálogo de exposição)

ARTE/CIDADE, 3. Arte/Cidade: a cidade e suas histórias. Exposição realizada no eixo ferroviário Moinho-Luz, em São Paulo. Texto de Nelson Brissac Peixoto. São Paulo: Secretaria de Estado da Cultura/Editora Marca D’Água, 1997. (Catálogo de exposição)

Arte em Revista (Independentes), Centro de Estudos de Arte Contemporânea, São Paulo, ano 6, n. 8, out. 1984.

Arte em São Paulo, edição especial Escola Brasil, São Paulo, n. 26, out. 1984.

BARCELLOS, Vera Chaves (org.). Julio Plaza: poéticas/políticas. Textos de Ignacio Gómez de Liaño, Julio Plaza, Regina Silveira, Vera Chaves Barcellos, Cristina Freire, Augusto de Campos e Alexandre Dias Ramos. Porto Alegre: Fundação Vera Chaves Barcellos, 2013.

BASBAUM, Ricardo e COIMBRA, Eduardo. Tornando visível a arte contemporânea 1995]. BASBAUM, Ricardo (org.) Arte contemporânea brasileira: texturas, dicções, ficcões, estratégias. Rio de Janeiro: Rios ambiciosos, 2001, pp. 345-349.

BELLUZZO, Ana Maria de Moraes. Arte no Brasil. Textos críticos. Século XX. São Paulo/
Houston: FAU-USP, FAPESP/Museum of Fine Arts, 2009. Disponivel em: <http/// icaadocs.mfah.org/icaadocs/en-us/thearchive>. Acesso em 2 jan. 2016.

Form and Space: Collaboration Between Architecture and the Plastic Arts. OLEA, Héctor e RAMIREZ, Mari Carmen (eds.). Building On a Construction: The Adolpho Leirner Collection of Brazilian Art at the Museum of Fine Arts, Houston. Houston: Museum of Fine Arts, 2009.

Lig des (Marcelo Nitsche). Exposição no Sesc Pompeia, 19 de junho a 30 de agosto. São Paulo: Sesc Pompeia, 2015. (Catálogo de exposição)

BELLUZZO, Ana Maria de Moraes et. al. (orgs.). Depoimentos sobre Flávio Motta, Caramelo, São Paulo, n. 6, pp. 41-53, ago. 1993.

BIENAL DE SÃO PAULO, 25. 25 $5^{a}$ Bienal Internacional de São Paulo - Iconografias Metropolitanas (Cidades). Textos de Alfons Hug. Ticio Escobar e Boris Groys. Exposiç̃o de 23 de março a 2 de junho. São Paulo: Fundação Bienal, 2002. (Catálogo de exposição)

BLANCO, Paloma et. al. (orgs.). Modos de hacer: arte crítico, esfera publica e y acción directa. Salamanca: Ediciones Universidad de Salamanca, 2001.

BREA, José Luiz. Ornamento y utopia: evoluciones de la escultura en los años 80 y 9o, Arte proyectosy ideas, Universidad Politécnica de Valencia - Vice Rectorado de Cultura, ano 4, vol. 1, n. 4, pp. 95-112, maio 1996.

BUONAVENTURA, Julia. Propriedades sem bens: dos lotes de Gordon Matta-Clark às manifestações de Félix González-Torres. Tese (Doutorado em História e Fundamentos da Arquitetura e do Urbanismo) - Faculdade de Arquitetura e Urbanismo FAU-USP, São Paulo, 2014.

BRITO, Ronaldo. Análise do circuito, Malasartes, n. 1, pp. 5-6, set./out./nov. 1975.

O moderno e o contemporâneo ( o novo e o outro novo). BASBAUM, Ricardo (org.). Arte contemporânea brasileira: texturas, dicções, ficções, estratégias. Rio de Janeiro: Rios Ambiciosos, 2001, pp. 202-215

CANONGIA, Ligia. O Legado dos anos 60 e 70 . Rio de Janeiro: Jorge Zahar, 2005.

Anos 80: embates de uma geração. Rio de Janeiro: Barleu /Francisco Alves, 2010.

CARRILlO, Jesús. Especialidad y arte público. BLANCO, Paloma et. al. (orgs.). Modos de hacer: arte criítico, esfera publica e y acción directa. Salamanca: Ediciones Universidad de Salamanca, 2001, pp. 127-142.

CHIARELLI, Tadeu. O tridimensional na arte brasileira dos anos 80 e go: genealogias, superações. ITAÚ CULTURAL. Tridimensionalidade. São Paulo: Instituto Cultural Itaú, 
1997, pp. 170-182. (Catálogo de exposição)

CLARK, T. J. Origins of the Present Crisis, New Left Review, n. 2, pp. 85-96, March-April 2000. CRIMP, Douglas. Sobre as ruínas do museu. São Paulo: Martins Fontes, 2005

. La redefinición de la especificidad espacial. BLANCO, Paloma et. al. (orgs.). Modos de hacer: arte criítico, esfera publica e y acción directa. Salamanca: Ediciones Universidad de Salamanca, 2001, pp. 143-172.

CYMBALISTA, Renato. Sobre espaços públicos impossíveis. MAZZUCCHELLI, Kiki; CYMBALISTA, Renato; NICOLAU, Ricardo (orgs.). Marcelo Cidade: empena cega. São Paulo: Cobogó, 2016, pp. 65-72.

DAVILA, Thierry. Marcher, créer: déplacements, flâneries, dérives dans l'art de la fin du xxe siècle. Paris: Editions du Regard, 2002.

DE DUVE, Thierry. Ex Situ, A@D, Special Issue Installation Art, pp. 25-30, 1998.

DEUTSCHE, Rosalyn. Evictions: Art and Spatial Politics. Cambridge/Londres: The MIT Press, 1998.

. Alternative Spaces. WALLIS, Brian (ed.). If You Live Here: The City in Art, Theory and Social Activism. A Project by Martha Rosler. Seattle: Bay Press, 1991, pp. 45-66. DISERENS, Corinne. O filme arquitetônico de Matta-Clark, Revista Tropico. Disponível em: <http://p.php.uol.com.br/tropico/html/textos/1095,1.shl>. Acesso em 4 out. 2017. DISERENS, Corinne (org.). Gordon Matta-Clark. Londres: Phaidon, 2003.

DUCHAMP, Marcel. O ato criador. BATTCOCK, Gregory (org.). A nova arte. São Paulo: Perspectiva, 1975, pp. 71-74.

FABRIS, Annateresa. Pretexto para uma intervenção, Arte em São Paulo, São Paulo, n. 22 , abr. 1984.

. Sombras simuladoras. MORAES, Angélica de (org.). Regina Silveira: cartografias da sombra. Sao Paulo: Edusp, 1995, pp. 189-201.

FARIAS, Agnaldo A. C. Arte/Cidade. [Projeto Arte/Cidade]. Disponível em: <http://www. artecidade.org.br/novo/ac1/20.htm\#Cidadez. Acesso em 6 dez. 2017.

FAVARETTO, Celso. A invenção de Hélio Oiticica. São Paulo: Edusp/Fapesp, 2000.

FELSHIN, Nina. Pero esto es arte? El espíritu del arte como activismo. BLANCO, Paloma et. al. (orgs.). Modos de hacer: arte criítico, esfera publica e y acción directa. Salamanca: Ediciones Universidad de Salamanca, 2001, pp. 73-94.
FERREIRA, Clória (cur ) Arte como questão: anos 70. São Paulo: Instituto Tomie Ohtake, 2007. (Catálogo de exposição)

. Situações: arte brasileira anos 70. Exposição de 16 de agosto a 24 de dezembro de 2000. Rio de Janeiro: Casa França-Brasil, 2000. (Catálogo de exposição)

FERREIRA, Glória (org.). Crítica de arte no Brasil: temáticas contemporâneas. Rio de Janeiro: Funarte, 2006.

FERREIRA, Glória e COTRIM, Cecilia (orgs.). Escritos de artistas: anos 60/70. Rio de Janeiro: Jorge Zahar Editor, 2006.

FLUSSER, Vilém. Fred Forest ou a destruição dos pontos de vista estabelecidos, ARS, São Paulo, vol. 7, n. 13, pp. 172-179, jan.-jun. 2009.

FOSTER, Hal. O retorno do real: a vanguarda no final do século XX [1ª edição 1996]. São Paulo: Cosac Naify, 2014.

FRASER, Andrea. O que é crítica institucional, Concinnitas, PPCA-UERJ, Rio de Janeiro, ano 15, vol. 2, n. 24, dez. 2014. Disponível em: <www.e-publicacoes.uerj.br/index. php/concinnitas/article/download/18731/13645>. Acesso em 5 out. 2017.

FRÉCHURET, Maurice. Les années 70: l'art en cause. Musée d'art contemporain de Bordeaux, 18 de outubro de 2002 a 19 de janeiro de 2003. Bordeaux: Cap-Musée d'art contemporain/Paris: Réunion des musées nationaux, 2002. (Catálogo de exposição)

FREITAS, Artur. Arte de guerrilha: vanguarda e conceitualismo no Brasil. São Paulo: Edusp, 2013.

FREIRE, Cristina. Espaço e lugar: os registros da paisagem urbana na arte contemporânea. SALGUEIRO, Heliana Angotti (coord.). Paisagem e arte: a invenção da natureza, a evolução do olhar. São Paulo: CBHA/CNPq/FAPESP, 2000, pp. 357-362.

. Por uma arqueologia do contemporâneo na cidade: fragmentos modernos em São Paulo. CUENCA, Rogelio López. Astilhãografo. XXV Edición de la Bienal de São Paulo - Iconografías Metropolitanas. Pabellón de Espanã, 22 marzo a 2 junio 2002. Ministerio de Asuntos Exteriores, 2002, pp. 103-112. (Catálogo de exposição)

O mito da cidade e a arte contemporânea. AJZENBERG, Elza (org.). Mario Schenberg: arte e ciência - mito e razão. São Paulo: ECA-USP, 2001, pp. 73-78.

FREIRE, Cristina (org.). Walter Zanini: escrituras críticas. São Paulo: MAC-USP/Annablume, 2015.

FURECATTI, Silvia. Artee meio urbano: elementos de formação da estética extra-muros no Brasil. Tese (Doutorado em História e Fundamentos da Arquitetura e do Urbanis- 
mo) - Faculdade de Arquitetura e Urbanismo FAU-USP, São Paulo, 2007.

GORELIK, Adrián. Las metrópolis latinoamericanas, el arte y la vida. Arte y ciudad en tiempos de globalización, Aisthesis, Pontificia Universidad Católica de Chile, n. 41, pp. 36-56, 2007.

GUIMARÃES, Andrea Camargo et. al. (ed.). Cronologia de artes plásticas: referências 1975 1995. São Paulo: Centro Cultural São Paulo, 2010.

HUDINILSON JR., RAMIRO, Mario e FRANÇA, Rafael. 3Nós3/Intervenção urbana, Arte em São Paulo, São Paulo, n. 2, out. 1981, pp.[9]-[12].

JACQUES, Paola Berenstein. Elogio aos errantes. Salvador: EDUFBA, 2014.

JACQUES, Paola Berenstein (org.). Apologia da deriva: escritos situacionistas sobre a cidade. Rio de Janeiro: Casa da Palavra, 2003.

JENKINS, Bruce. Gordon Matta-Clark: Conical Intersect. Londres: Afterall Books, 2011. (One Work Series)

KRAUSS, Rosalind. A Voyage on the North Sea: Art in the Age of the Post-medium Condition. Nova York: Thames \& Hudson, 1999.

. O fotográfico [1990]. Barcelona: Gustavo Cili, 2002.

Sculpture in the Expanded Field [1985]. The Originality of the Avant-Garde and Other Modernist Myths. Cambridge/Londres: The MIT Press, 1996, pp. 276-290.

KWON, Miwon. One Place After Another: Site Specific Art and the Locational Identity. Cambridge: The MIT Press, 2002.

LEE, Pamela M. Object To Be Destroyed: The Work of Gordon Matta-Clark. Cambridge MA/ Londres: The MIT Press, 2000.

LIPPARD, Lucy. A desmaterialização da arte, Arte Ensaios, Revista do PPCAV/EBA/UFRJ, Rio de Janeiro, n. 25, pp. 150-165, maio 2013.

Looking Around: Where We Are, Where We Could Be. LACY, Suzanne (ed.). Mapping the Terrain: New Genre Public Art. Bay Press, 1995, pp. 114-130.

MADERUELO, Javier. El espacio raptado: interferencias entre arquitectura y escultura. Madrid: Biblioteca Mondadori, 1990.

_. La idea de espacio en la arquitectura y el arte contemporáneos, 1960-1989. Madrid: Akal, 2008. MAMMİ, Lorenzo. Mortes recentes da arte, Novos Estudos, Cebrap, n. 6o, pp. 77-86, jul. 2001

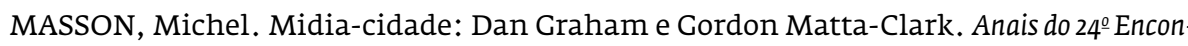

tro da Anpap: Compartilhamentos na Arte - Redes e Conexões. Santa Maria: UFSM, 2015, pp. 2357-2373.

MEIRELES, Cildo. Quem se desloca recebe, quem pede tem preferência, Malasartes, pp. 14-19, n. 1, set./out./nov. 1975

MEYER, James. Nomads: Figures of Travel in Contemporary Art. COLES, Alex (org.). Site-Specificity: The Ethnographic Turn. Londres: Black Dog Publishing, 2000, pp. 10-29. MIRANDA, Danilo Santos de (org.). Arte pública. São Paulo: Sesc, 1998.

MORAIS, Frederico. Artes plásticas: a crise da hora atual. Rio de Janeiro: Paz e Terra, 1975. Depoimento de uma geração: 1969-1970. Rio de Janeiro: Galeria de Arte Banerj, 1986. . Frederico Morais. Organização Silvana Seffrin. Rio de Janeiro: Funarte, 2004. (Coleção Pensamento crítico n. 2)

MOTTA, Flavio L. Desenho e emancipação, Correio Braziliense, 16 dez. 1967.

. Textos informes. São Paulo: FAU-USP, 1973.

MOTTA, Flavio L. e NITSCHE, Marcello. Arte na cidade. Arte na cidade. Curitiba: Fundação Cultural de Curitiba, 1975. (Catálogo de exposição)

NAVES, Rodrigo. Um Azar histórico: desencontros entre moderno e contemporâneo na arte brasileira, Novos Estudos, Cebrap, São Paulo, n. 64, pp. 5-21, nov. 2002.

OITICICA, Hélio. Esquema geral da nova objetividade [1966]. Aspiro ao Grande Labirinto. Rio de Janeiro: Rocco, 1986, pp. 84-98.

. Situação da vanguarda no Brasil [1966], Arte em Revista, Centro de Estudos de Arte Contemporânea, São Paulo, ano 1, n. 2, p. 31, maio-ago. 1979.

PALHARES, Taisa. Anarquismo construtivo [?!], número, n. 1. Disponível em: <http:// www.forumpermanente.org/rede/numero/rev-numero//taisaznos3>. Acesso em $3 \mathrm{dez}$.

PALLAMIN, Vera. Arte, cultura e cidade. São Paulo: Invisíveis Produções/Annablume, 2015.

Percepções e intervenções na metrópole: a experiência do projeto Arte/Cidade em São Paulo (1994-2002), Risco - Revista de Pesquisa em Arquitetura e Urbanismo, PPGAUEESC/USP, n. 4, pp. 151-152, 2006

PEDROSA, Mário. Arte ambiental, arte pós-moderna, Hélio Oiticica. Acadêmicos e modernos: textos escolhidos III. Organização Otília F. B. Arantes. São Paulo: Edusp, 2004, pp. 355-360 
Arte/Cidade-Um balanco, ARS, vol, 4, n. 7, São Paulo, 2006, pp. 85-89. Disponível em: <http://www.scielo.br/scielo.php?script=sci_arttext\&pid=\$1678-53202006000100008> Acesso em 28 dez. 2017.

Intervençōes urbanas: Arte/Cidade. São Paulo: Editora Senac, 2002.

PLAZA, Julio. Arte/Ciência: uma cons-ciência. AJZENBERG, Elza (org.). Mario Schenberg: arte e ciência - mito e razão. São Paulo: ECA-USP, 2001, pp. 320-328.

. Poéticas visuais. Exposição de 29 de setembro a 30 de outubro de 1977. São Paulo: MAC-USP, 1977. (Catálogo de exposição)

RAMIRO, Mario (org.). 3Nós3: intervenções urbanas 1979-1982. São Paulo: UBU, 2017. RESENDE, José. A Ausência da Escultura, Malasartes, n. 3, pp. 4-8, abr.-jun. 1976.

ROUILLÉ, André. A fotografia: entre documento e arte contemporânea. São Paulo: Senac, 2009. SALZSTEIN, Sonia e BANDEIRA, João (orgs.). Historicidade e arte contemporânea: ensaios e conversas. São Paulo: ICC/Centro Universitário Mariantonia/Fapesp, 2012.

SEVCENKO, Nicolau. Configurando os anos 70: a imaginação no poder e a arte nas ruas. ANOS 70: trajetórias. São Paulo: Itaú Cultural/Iluminuras, 2005, pp. 13-34.

SILVEIRA, Regina. Regina Silveira: compêndio (RS). Belo Horizonte: Museu de Arte da Pampulha, 2007. (Catálogo de exposição)

SMITHSON, Robert. Um passeio pelos monumentos de Passaic, Nova Jersey [1 $1 \underline{a}$ edição 1967], Espaço \& Debate, v. 23, n. 43-44, pp. 123-140, jan./fev. 2003.

STILES, Kristine \& SELZ, Peter. Theories and Documents of Contemporary Art: A Sourcebook of Artist's Writings. Berkeley/Los Angeles: University of California Press, 1996. (California Studies in the History of Art, n. 35)

SOUZA, Gabriel G. E. de. Percepções e intervenções na metrópole: a experiência do projeto Arte/Cidade em São Paulo (1994-2002). Dissertação (Mestrado) - Escola de Engenharia de São Carlos EESC-USP, São Carlos, 2006.

VASCONCELLOS, Jorge. A anarcoarquitetura de Gordon Matta-Clark: autonomismo político e ativismo estético, Arte \& Ensaios, Rio de Janeiro, n. 25, pp. 88-99, maio 2013.

VENANCIO FILHO, Paulo. Experiment/Experiência: art in Brasil 1958-2000 [2001]. A presença da arte. São Paulo: Cosac Naify, 2013, pp. 31-38.

VISCONTI, Jacopo. Novas derivas. São Paulo: WMF Martins Fontes, 2015.

WISNIK, Guilherme. Dentro do nevoeiro: diálogos cruzados entre arte e arquitetura con- temporânea. Tese (Doutorado em História e Fundamentos da Arquitetura e do Urbanismo) - Faculdade de Arquitetura e Urbanismo FAU-USP, São Paulo, 2012.

WOOD, Jon, HULKS, David e POTTS, Alex (orgs.). Modern Sculpture Reader. Leeds: Henry Moore Institute, 2007.

YEE, Lydia (cur.). Laurie Anderson, Trisha Brown, Gordon Matta-Clark: Pioneers of The Downtown Scene, New York 1970s. Exposição realizada na Barbican Art Gallery, 3 de março a 22 de maio de 2011. Londres: Barbican Center/Munique: Prestel Verlag, 2011. (Catálogo de exposição)

ZANINI, Walter. História geral da arte no Brasil. São Paulo: Instituto Walther Moreira Salles/Fundação Djalma Guimarães, 1983. (Vol. 2)

\section{RUBENS MANO}

ALBUQUERQUE, Fernanda. Práticas artísticas orientadas ao contexto e crítica em âmbito institucional. Tese (Doutorado em Artes Visuais) - Instituto de Artes da UFRGS, Porto Alegre, 2015

ALVES, Cauê (cur.). Quase líquido. São Paulo: Itaú Cultural, 2008. (Catálogo de exposição)

ANDREOLI, Elisabetta e SANTOS, Laymert Garcia dos. Arte pública, cidade privada [1999]. PEIXOTO, Nelson Brissac (org.). Intervenções urbanas: arte/cidade. São Paulo: Senac, 2002, pp. 284-293.

ANDRÉS, Roberto. Brasília dos grotões e da prancheta. A beleza de quem usa o automóvel e o desalento dos que vão de ônibus, Drops, São Paulo, ano 10, n. 031.03, Vitruvius, abr. 2010. Disponível em: <http://www.vitruvius.com.br/revistas/read/ drops $/ 10.031 / 3412>$. Acesso em 20 dez. 2017.

ANTENORE, A. Sob protesto, Rubens Mano deixa a Bienal de São Paulo, Folha de S.Paulo, 24 maio 2002.

BATISTA, Helmut. Rubens Mano e Helmut Batista (entrevista), Jornal Capacete, n. 4, Capacete Projects, Rio de Janeiro, jul. 2002.

BELCHIOR, Camila. Rubens Mano, ArtNexus, n. 71, Bogotá, pp. 149-15o, dec./feb. 2008.

BOHNS, Neiva. Arte na cidade: do lado de fora, no meio de tudo, Revista Panorama Crítico, n. 10, mar.-abr. 2011. Disponível em: <https://www.panoramacritico.com/revista10?start=1>. Acesso em 29 dez. 2017. 
BUENAVENTURA, Julia. Rubens Mano: exposición Contrato Social, ArtNexus, Bogotá, n. 97, 2015. Disponível em: <http://juliabuenaventura.blogspot.com.br/p/artista-rubens-mano.html?m=1>. Acesso em 8 jan. 2018

CHIARELLI, Tadeu. A cidade não mais como obstáculo: a produção de Rubens Mano [2000]. TREVISAN, Ricardo (org.). Casa Triângulo 2013-1998. São Paulo: Ipsis, 2014. pp. 538-540.

. A fotografia contaminada [1994]. Arte internacional brasileira. São Paulo: Lemos-Editorial, 1999, pp. 115-120.

CHIODETTO, Eder. Cego de tanto ver, Rubens Mano investiga cidade desmaterializada, Folha de S.Paulo, Ilustrada, 4 dez. 2004

COSTA, Helouise. Rubens Mano, Paparazzi, n. 6, ano 1, pp. 40-41, jul.-ago. 1996.

COSTA, Ariel Ferreira. Pequena coleção de obras não realizadas: obras imaginadas, projetos e instruções. Dissertação (Mestrado) - Escola de Belas Artes da UFMC, Belo Horizonte, 2009.

CYPRIANO, Fabio. Rubens Mano, Frieze, Londres, n. 118, p. 307, October 2008. Disponível em: <http://www.frieze.com/issue/review/rubens_mano/>. Acesso em 29 dez. 2017.

ESPADA, Heloisa. Lugar nenhum, Blog do IMS, 6 maio 2013. Disponível em: <https:// blogdoims.com.br/lugar-nenhum-por-heloisa-espada/>. Acesso em 14 set. 2017.

Monumentalidade e sombra: a representação do centro cívico de Brasília por Marcel Gautherot. Tese (Doutorado em História, Crítica e Teoria da Arte) - Escola de Comunicações e Artes ECA-USP, São Paulo, 2011.

ESPADA, Heloisa (cur.). As construções de Brasília. Textos de Heloisa Espada, Lorenzo Mammì, Sergio Burgi, Anat Falbel e Laymert Garcia dos Santos. Exposição realizad no Instituto Moreira Salles/RJ, de 30 de abril a 25 de julho de 2010, e na Galeria de Arte do Sesi-Centro Cultural Fiesp/SP, de 28 de setembro de 2010 a 30 de janeiro de 2011. São Paulo/Rio de Janeiro: IMS, 2010. (Catálogo de exposição)

FABRIS, Annateresa. Identidades virtuais: uma leitura do retrato fotográfico. Belo Horizonte: UFMC, 2004.

FARIAS, Agnaldo. São Paulo, ó quão dessemelhante! $25^{\underline{a}}$ Bienal de São Paulo: Iconografias Metropolitanas-Cidades. São Paulo: Fundação Bienal de São Paulo, 2002, pp. 244-271. (Catálogo de exposição)

FARKAS, Solange. El futuro que nos acecha/The Future That Haunts Us, Atlântica - Revista de Arte y Pensamiento, Centro Atlántico de Arte Moderno (CAAM), Las Palmas de
Cran Canaria n. 59, mayo 2017. Disponível em: <http://www revistaatlantica com/ contribution/futuro-nos-acecha/>. Acesso em $28 \mathrm{dez} .2017$.

HUG, Alfons. Iconografias Metropolitanas. $25^{a}$ Bienal de São Paulo-Países. São Paulo: Fundação Bienal de São Paulo, 2002, pp. 16-23. (Catálogo de exposição)

CARBELOTTI, Raquel. Informal Encounter. CARLOS, Isabel (cur.). $14^{\text {th }}$ Biennale of Sydney: On Reason and Emotion. Sydney: Museum of Contemporary Art, 2004.

KATZENSTEIN, Inés. Rubens Mano. Creamier: Contemporary Art in Culture. Londres: Phaidon, 2010, pp. 162-163.

LAGNADO, Lisette. Arte/cidade: a cidade e seus fluxos, Trans: Arts.Cultures.Media, vol. 1, n. 1, pp. 118-120, primavera 1995. Disponível em: <http://www.transmag.org/nuevo_transmag/nuevodiseno/content/vols.php?vista=issue\&tipoview=Architecture\&vie$\mathrm{w}=64$ \&descview=Arte/Cidade/Art/\%20City>. Acesso em 2 dez. 2017.

MAMMİ, Lorenzo. As bordas. O que resta: arte e crítica de arte. São Paulo: Companhia das Letras, 2012, pp. 54-117.

Encalhes e desmanches: ruínas do modernismo na arte brasileira. O que resta: arte e crítica de arte. São Paulo: Companhia das Letras, 2012, pp. 214-227.

Evento acha cidade morta dentro da cidade atual [1997]. FERREIRA, Clória (org.). Crítica de arte no Brasil: temáticas contemporâneas. Rio de Janeiro: Funarte, 2006, pp. 481-484. (Coleção Pensamento Crítico)

. Novo "Arte/Cidade" fica aquém do esperado, O Estado de S. Paulo, Caderno Cultura, p. Q1, 8 out. 1994.

MAMMİ, Lorenzo e ESPADA, Heloisa. As imagens de Passaic. Lugar nenhum. São Paulo: IMS, 2013, pp. 6-18. (Catálogo de exposição)

MANESCHY, Orlando F. Rubens Mano e os fluxos luminosos. II Encontro de História da Arte. Campinas: IFCH/Unicamp, 2006, pp. 360-364.

Vetores e experimentações estéticas nas múltiplas amazônias: por uma coleção amazoniana de arte da UFPA.MEDEIROS, Afonso e HAMOY, Idanise (orgs.). Anais do $22^{\circ}$ Encontro da Anpap: ecossistemas estéticos. Belém: ANPAP;PPGARTES/ ICA/UFPA, 2013, pp. 1794-1807. Disponível em: <http://anpap.org.br/anais/2013/ ANAIS/comites/c/Orlando\%2OFranco\%2OManeschy.pdf>. Acesso em 29 dez. 2017

MANO, Rubens. a condição do lugar no site, ARS, São Paulo, vol. 4, n. 7, pp. 112122, 2006a. Disponível em: <http://www.scielo.br/scielo.php?script=sci_arttext\&pi$d=$ =1678-53202006000100011>. Acesso em 20 dez. 2016 
intervalo transitivo. Dissertação (Mestrado em Poéticas Visuais) - Departamento de Artes Plásticas da Escola de Comunicações e Artes ECA-USP, São Paulo, 2003.

. [texto sobre o projeto para a obra futuro do pretérito], incessante [site do artista]. Disponível em: <http://www.incessante.org/>. Acesso em 5 jan. 2018.

. um lugar dentro do lugar, Urbania, n. 3, São Paulo, pp. 101-111, 2006b. Disponível em: <http://urbania4.org/wp-content/uploads/2010/10/revista-urbania-3.pdf>. Acesso em 22 jul. 2016.

. vazadores, 2002. 25를 Bienal de São Paulo, Recibo 80, Edições Traplev Orçamentos, ano 13, n. 18, pp. 46-50, 2015. Disponível em: <https://traplev.hotglue.me/?r80>. Acesso em 20 nov. 2016.

MANO, Rubens e MARTINS, Sergio. futuro do pretérito [composto], ZUM - revista de fotografia, IMS, São Paulo, n. 6, pp. 110-121, abr. 2014.

MESOUITA, Ivo. Rubens Mano: contemplação suspensa. Exposição no Projeto Octógono Arte Contemporânea, de 26 de julho a 5 de outubro. São Paulo: Pinacoteca do Estado, 2008. (Folder de exposição)

MOURA, Rodrigo e ZACCAGNINI, Carla. XXV Bienal de São Paulo, ArtNexus, Bogotá n. 46 , pp. 30-33, 2002

OLIVA, Fernando. A discussão que reuniu o artista Rubens Mano e os críticos Celso Favaretto e Lisette Lagnado, Tropico, seção "Em obras", 2002. Disponível em: <http://p.php.uol.com.br/tropico/html/textos/1254,1.shl>. Acesso em 29 dez. 2017.

OLIVEIRA, Emerson Dionísio de. Museu-obra: o museu como problema da arte contemporânea, Museologia @ Interdisplinariedade, vol. 5, n. 10, pp. 157-167, jul.-dez. 2016.

PEIXOTO, Nelson Brissac. El impacto de la metrópoles en la creación contemporánea, Lapiz, n. 134-135, pp. 80-88, jul.-sept. 1997.

. Intervenciones urbanas, Poliester [Arquitetura], vol. 5, n. 15, pp. 20-27, primavera 1996.

. Paisagens urbanas. São Paulo: Martins Fontes/Senac, 2004.

. Arte \& Cidade [1998]. FERREIRA, Glória (org.). Crítica de arte no Brasil: temáticas contemporâneas. Rio de Janeiro: Funarte, 2006, pp. 485-493.

Intervenções urbanas: arte/cidade. São Paulo: Senac, 2002.

PELED, Yiftah. Interfaces expositivas, Revista do Colóquio de Arte e Pesquisa do PPCA-UFES, Vitória, ano 3, v. 3, n. 5, pp. 146-16o, dez. 2013.
PICCOLI, Valeria, Rubens Mano, ArtNexus, Bogotá, n. 40, pp. 126-127, abr./jun. 2001. RIBEIRO, José Augusto. Rubens Mano, ArtNexus, Bogotá, vol. 3, n. 57, pp. 153-154, jun.-ago. 2005.

RIVITTI, Thaís. Cidade tombada. SALZSTEIN, Sonia e BANDEIRA, João (orgs.). Historicidade e arte contemporânea: ensaios e conversas. São Paulo: ICCo/CEUMA-USP, 2012, pp. 164-172.

. Inserções Silenciosas [Entrevista com Rubens Mano], número, n. 1, São Paulo, p. 11, maio-jun. 2003. Disponível em: <http://www.forumpermanente.org/rede/numero/rev-numero//umentrevistamano>. Acesso em 29 dez. 2017.

_. Uma obra para museu, ARS, São Paulo, n. 13, pp. 150-159, 2010. Disponível em: <http://www.scielo.br/scielo.php?script=sci_abstract\&pid=\$1678-5320200900010oo10\&lng=pt\&nrm=is\&tIng=en>. Acesso em 4 dez. 2017.

SÁNCHEZ, Osvaldo. Rubens Mano. 100 Artistas latinoamericanos. Madrid: Exit, 2007, s.p.

SANTOS, Laymert Garcia dos. A arte na cidade: entre a deslocalização e o deslocamento. PEIXOTO, Nelson Brissac (cur.). Arte/Cidade: a cidade e seus fluxos. São Paulo: Marca d'Água/Secretaria de Cultura do Estado de São Paulo, 1994, s.p. (Catálogo de exposição).

. A tecnoestética de Rubens Mano. Politizar as novas tecnologias. São Paulo: Editora 34, 2003, pp. 206-211.

. Futuro do pretérito: do espaço moderno ao espírito do lugar. FINCUERUT, Silvia (org.). Artee Patrimônio 2007-2010. Brasília: Iphan, 2010, pp. 230-243. (n. 230)

. Rubens Mano expõe a metamorfose da percepção, Folha de S.Paulo, Caderno Ilustrada, São Paulo, 16 nov. 2000.

. Un art de l'espace et de sa production, Parachute, n. 116, Montreal, oct.-dic. 2004. TASSINARI, Alberto. Escala do espaço parece ter inibido intensidade estética, O Estado de S. Paulo, Caderno Cultura, p. Q1, 8 out. 1994.

TONE, Lilian. Rubens Mano: On Light and Power. Disponível em: <http://www.mit. edu/ allanmc/liliantone2.pdf>. Acesso em 20 out. 2017.

\section{OUTRAS FONTES DE PESQUISA}




\section{BIBLIOTECAS E ARQUIVOS CONSULTADOS}

Arquivo Histórico Wanda Svevo - Fundação Bienal

Biblioteca da Escola de Comunicações e Artes - ECA-USP

Biblioteca da Escola de Engenharia de São Carlos - EESC-USP

Biblioteca da Faculdade de Arquitetura e Urbanismo - FAU-USP

Biblioteca Florestan Fernandes da Faculdade de Filosofia Letras e Ciências Humanas - FFLCH-USP

Biblioteca do Instituto de Estudos Brasileiros - IEB-USP

Biblioteca do Museu de Arte Contemporânea - MAC-USP

Biblioteca do Museu de Arte Moderna de São Paulo - MAM-SP

Biblioteca da Universidade Federal de Uberlândia - UFU

\section{PRINCIPAIS SITES CONSULTADOS}

Arte/Cidade - grupo de intervenção urbana <http://www.artecidade.org.br/indexp. $\mathrm{htm}>$

Enciclopédia Itaú Cultural de Artes Visuais <http://www.itaucultural.org.br/aplicexternas/enciclopedia_ic/index.cfm>

Fundação Bienal de São Paulo [site e blog] <http://www.bienal.org.br/>

Galeria Milan, São Paulo <http://www.galeriamillan.com.br/>

Galeria Adhoc, Vigo (Espanha) <http://www.adhocgaleria.com/>

incessante [site do artista] <http://www.incessante.org/>

\section{MATERIAIS AUDIOVISUAIS}

MANO, Rubens. O espaço enquanto imagem projetada [palestra do artista]. São Paulo: Escola da Cidade, 2009. 57 min. Disponível em: <http://escoladacidade. org/bau/rubens-mano-o-espaco-enquanto-imagem-projetada/>. Acesso em $2 \mathrm{dez}$ 2017.

RAMIRO, Mario. [Depoimento do artista para a exposição Obra e Documento - Arte/Ação e 3Nós3]. São Paulo: Centro Cultural São Paulo, 2012. Disponível em: <https//vimeo. com/61711050>. Acesso em 5 dez. 2015

\section{EXPOSIC̣̃̃ES E MOSTRAS VISITADAS}

Imanente [adiçãa_multiplicação_divisãa_subtração_], exposição individual de Rubens Mano. Artista convidado doa III Mostra do Programa de Exposições 2014, Centro Cultural São Paulo, São Paulo, nov. 2014-fev. 2015.

Experiência paulistana, curadoria de Tadeu Chiarelli. Estação Pinacoteca, São Paulo, abr.-set. 2017.

São Paulo nãoéuma cidade, curadoria de Paulo Herkenhoff e Leno Veras. Sesc 24 de Maio, São Paulo, ago. 2017-jan. 2018

Pedra no céu - arte e arquitetura de Paulo Mendes da Rocha, curadoria de Cauê Alves. Museu Brasileiro da Escultura - MuBE, São Paulo, abr.-jul. 2017.

SubTotal, exposição individual de Marcelo Cidade. Museu Brasileiro da Escultura MuBE, São Paulo, out.-nov. 2017.

Ser urbano, exposição individual de Carlos Garaicoa. Espaço Cultural Porto Seguro, São Paulo, fev.-maio 2018 
índice de imagens 
40 FIG. 1 Rubens Mano. $s /$ título [contra campo], 1987

40 FIG. 2 Rubens Mano. s/título, 1994

40 FIG. 3 Rubens Mano. corpus alienum, 1993

40 FIG. 4 Rubens Mano. eminente circuito, 1995

96 FIG. 5 Rubens Mano. Registro da montagem das lâmpadas em bueiro, 1999

108 FIG. 6 Rubens Mano. Registro da casa antes da demolição, av. Casa Verde, 1997

108 FIG. 7 Rubens Mano. Registro do processo de demolição, av. Casa Verde, 1997

120 FIG. 8 Gordon Matta-Clark. Bronx Floors, 1972

20 FIG. 9 Gordon Matta-Clark. Bronx Floor, 3A, 1973

120 FIG. 10 Gordon Matta-Clark. Conical Intersect, 1975

128 FIG. 11 Fotografia anônima, revista surrealista Le Minotaure, 1937

128 FIG. 12 Gordon Matta-Clark. Conical Intersect, 1975

132 FIG. 13 Rubens Mano. observador, 2001

132 FIGS. 14-15 Julio Plaza. Série Antifotografias, 1971-73

156 FIG. 16 Laura Vinci. Sem título, 1997

156 FIG. 17 José Resende. Sem título, 2002

176 FIG. 18 Rubens Mano. Detalhe do conjunto de equipamentos dos refletores, 1994

176 FIG. 19 Rubens Mano. Teste com o refletor militar no litoral paulista, 1994

190 FIGS. 20-21 Ana Maria Tavares. Cityscape, 2001

204 FIG. 22 Rubens Mano. telhado, 1999

204 FIG. 23 Rubens Mano. parede, 1999

240 FIGS. 24-25 3Nós3. Operação X-Galeria, 1979 [ação]

240 FIG. 26 3Nós3. Operação X-Galeria, 1979 [projeto]

256 FIGS. 27-28 Regina Silveira. Série Brazil Today, 1977

256 FIG. 29 Caio Reisewitz. Ministério das Relações Interiores (Palácio do Itamaraty) II, 2005

258 FIG. 30 Clarissa Tossin. Mármore branco todo dia, 2009

258 FIG. 31 Carla Zaccagnini. Evidências de uma farsa, 2011

262 FIG. 32 Rubens Mano. espaço aberto/espaço fechado, 2002

286 FIG. 33 Lucio Costa. Croqui original para o concurso de Brasília, 1957

286 FIG. 34 Vista aérea dos eixos do plano piloto de Brasília em construção, 1957c.

302 FIG. 35 Rubens Mano. Registro do processo de confecção do tijolo na olaria, 2014

302 FIG. 36 Rubens Mano. Registro do tijolo imanente na versão avermelhada, 2014

302 FIG. 37 Rubens Mano durante a substituição dos tijolos, 2014

316 FIGS. 38-39 Gordon Matta-Clark. Splitting, 1974

316 FIG. 40 Gordon Matta-Clark. Splitting: Four Corners, 1974 
320 FIG. 41 Vista do local antes da intervenção de Matta-Clark, Paris, 1975. Foto: Marc Petitjean

320 FIG. 42 Gordon Matta-Clark. Conical Intersect, 1975

322 FIG. 43 Gordon Matta-Clark. Projeto para Conical Intersect, 1975

322 FIG. 44 Gordon Matta-Clark. Detalhe de Conical Intersect, 1975. Foto: Marc Petitjean

322 FIGS. 45-46 Gordon Matta-Clark. Conical Intersect, 1975. Fotos: Marc Petitjean 


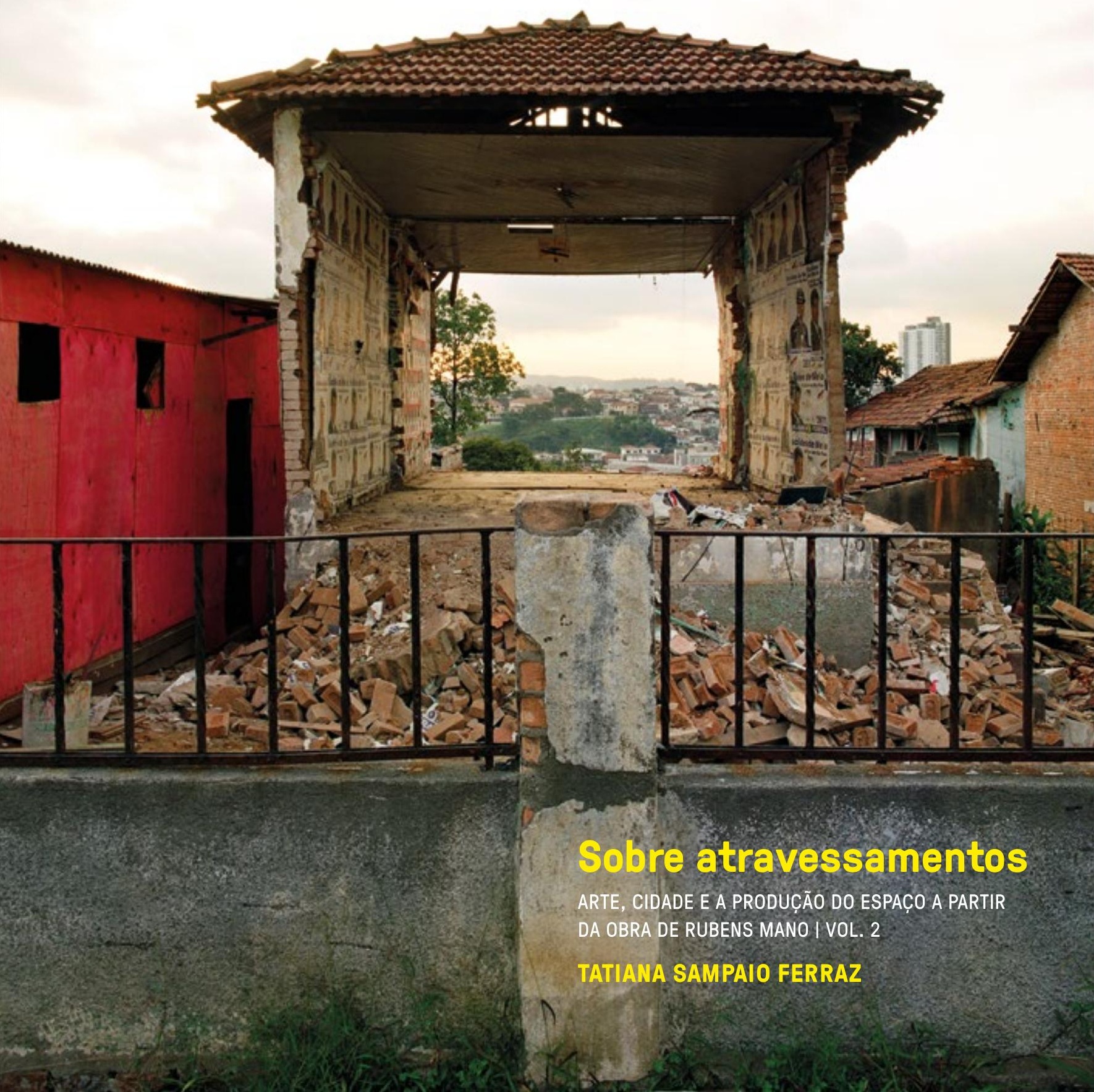



SOBRE ATRAVESSAMENTOS:

ARTE, CIDADE E A PRODUC̣ÃO

DO ESPAÇO A PARTIR DA OBRA

DE RUBENS MANO

VOL.2

ESTE CADERNO DE IMAGENS REPRODUZ

AS PRINCIPAIS OBRAS DE RUBENS MANO ABORDADAS NA TESE E COMO TAL NÃO DEVE SER VEICULADO SEPARADAMENTE. 
Autorizo a reprodução e divulgação total ou parcial deste trabalho, por qualquer meio convencional ou eletrônico, para fins de estudo e pesquisa, desde que citada a fonte.

Catalogação na Publicação | Serviço Técnico de Biblioteca Faculdade de Arquitetura e Urbanismo da Universidade de São Paulo

Ferraz, Tatiana Sampaio

Sobre atravessamentos: arte, cidade e a produção do espaço a partir da obra de Rubens Mano / Tatiana Sampaio Ferraz; orientadora Ana Maria de Moraes Belluzzo.

São Paulo, 2018 | 2 v.

Tese (Doutorado) - Faculdade de Arquitetura e Urbanismo da Universidade de São Paulo. Área de concentração: História e Fundamentos da Arquitetura e do Urbanismo

1. Mano, Rubens. 2. Arte Contemporânea. 3. Produção do Espaço. 4. Arte e Cidade. 5. Experiência Urbana. I. Belluzzo, Ana Maria de Moraes, orient. II. Título. 


\section{ÍNDICE DAS OBRAS}

5 casa verde, 1997

7-9 bueiro, 1999

11 disponha, 2001

13 entre, 2003

15-21 série súbitas paisagens, 2006-07

23-27 detetor de ausências, 1994

28-31 calçada, 1999

33 vazadores, 2001 [ $1^{\text {a }}$ parte, não realizada]

35-39 vazadores, 2001 [2 ${ }^{\mathrm{a}}$ parte, realizada]

40-45 futuro do pretérito, 2010

46-55 imanente, 2014 


\section{casa verde, 1997}

intervenção/fotografia, $135 \times 135 \times 4,5 \mathrm{~cm}$

impressão em papel RC brilhante

montada em moldura de madeira

Av. Casa Verde, São Paulo

\section{4 | 5}




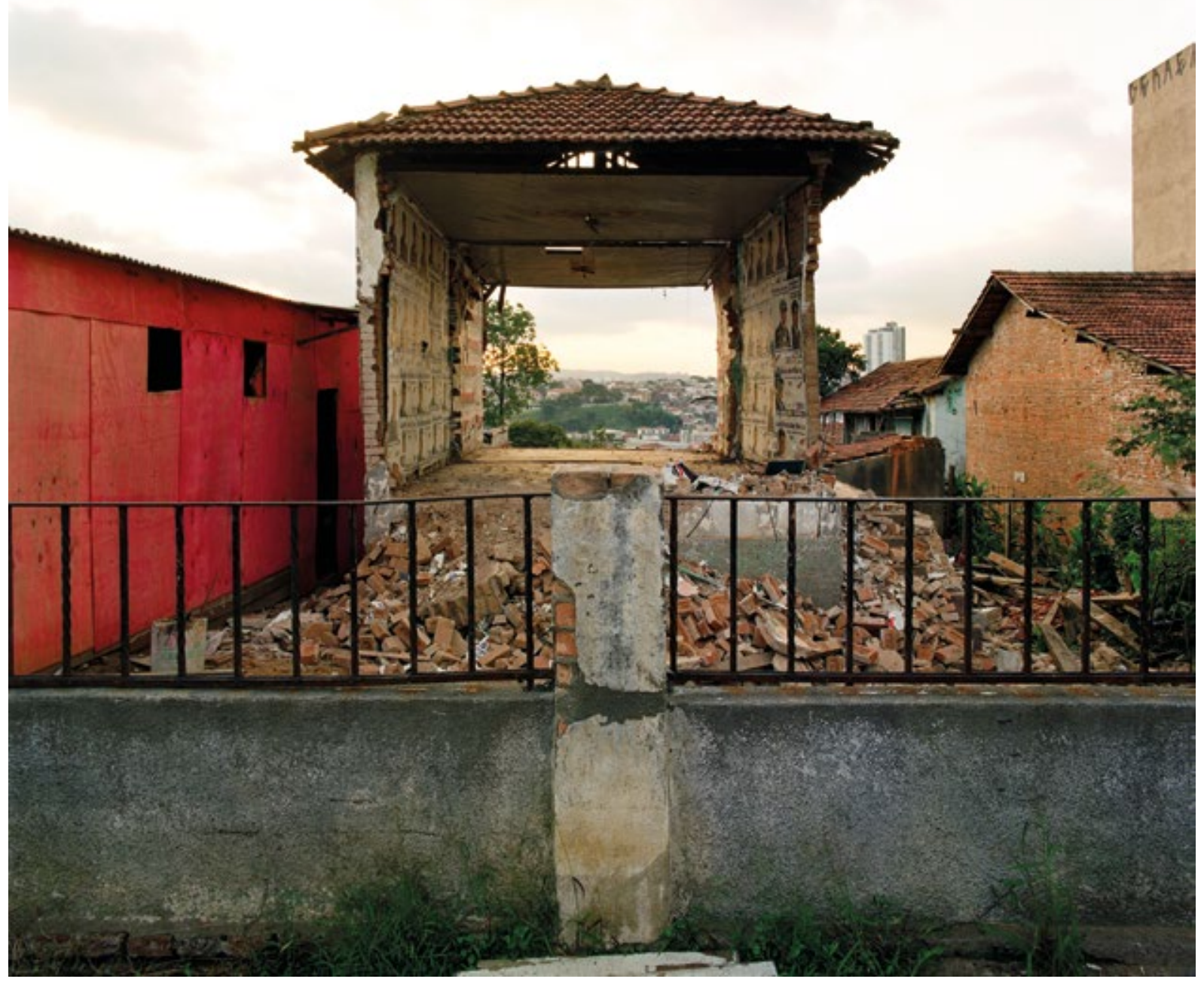




\section{bueiros [da serie huecos], 1999}

instalação/fotografia, $131 \times 131 \times 4,5 \mathrm{~cm}$ instalação com lâmpadas

fluorescentes, reatores e cabos elétricos; ampliação fotográfica em papel RC brilhante montada em moldura de madeira

Bairro do Bom Retiro, São Paulo 


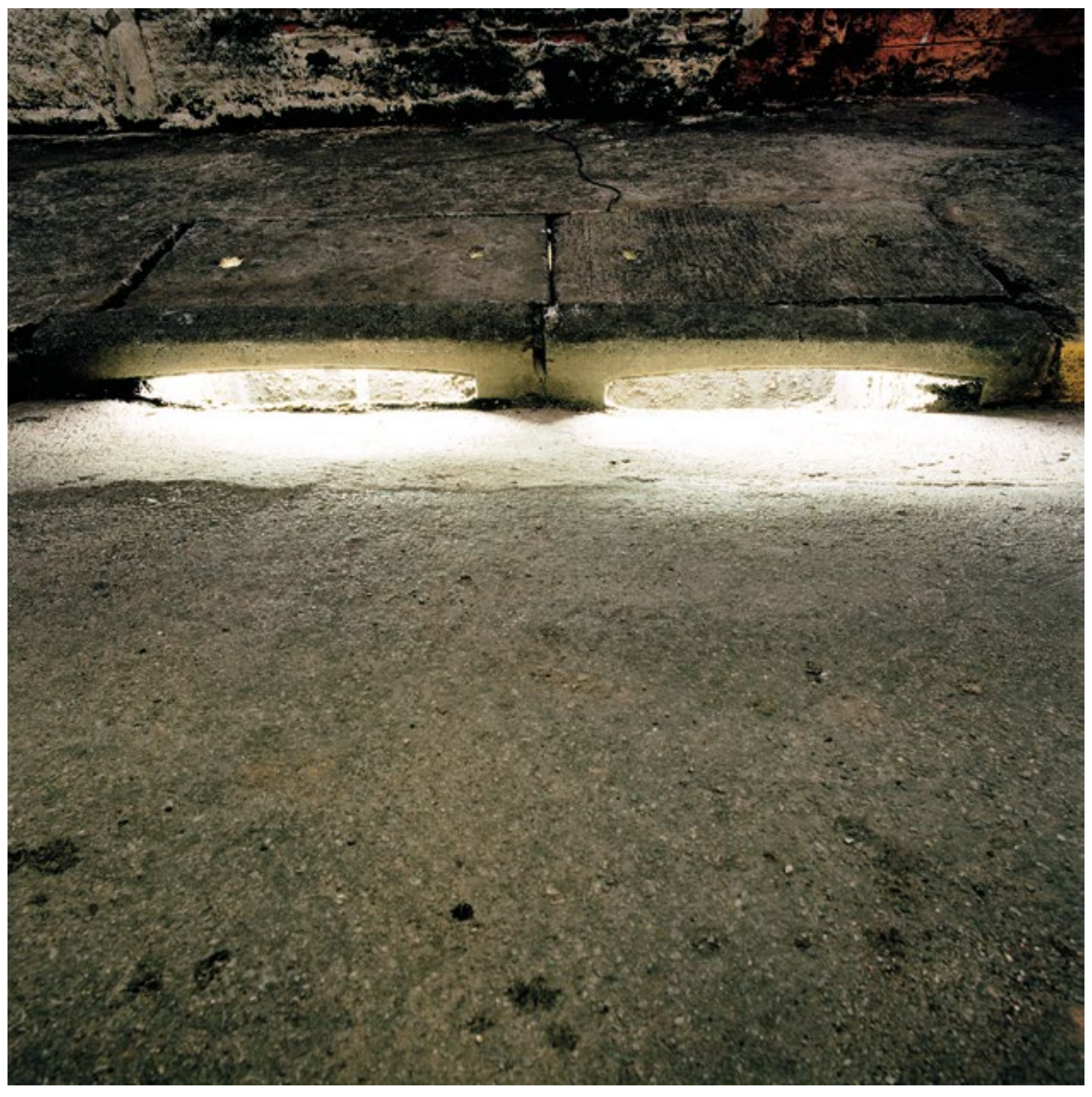




\section{bueiros [da serie huecos], 1999}

instalação/fotografia, 131 × 131 × 4,5 cm

instalação com lâmpadas

fluorescentes, reatores e cabos

elétricos; ampliação fotográfica

em papel RC brilhante montada

em moldura de madeira

Mairro do Bom Retiro, São Paulo

$8 \mid 9$ 


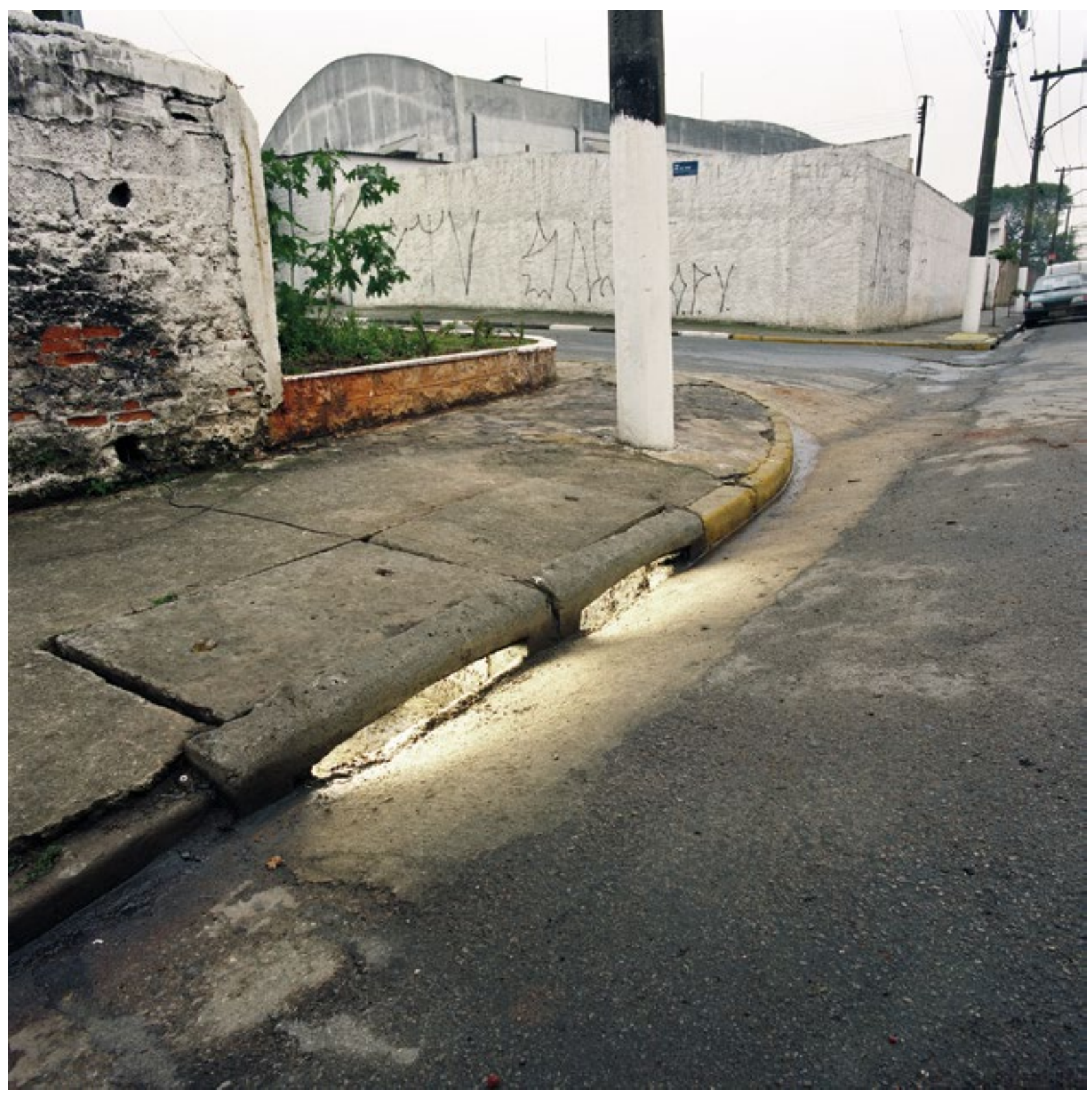


disponha, 2001

díptico em fotografia, $110 \times 231 \times 3 \mathrm{~cm}$

(total); $110 \times 108 \times 3 \mathrm{~cm}$ (cada)

impressão montada em metacrilato

10 | 11 

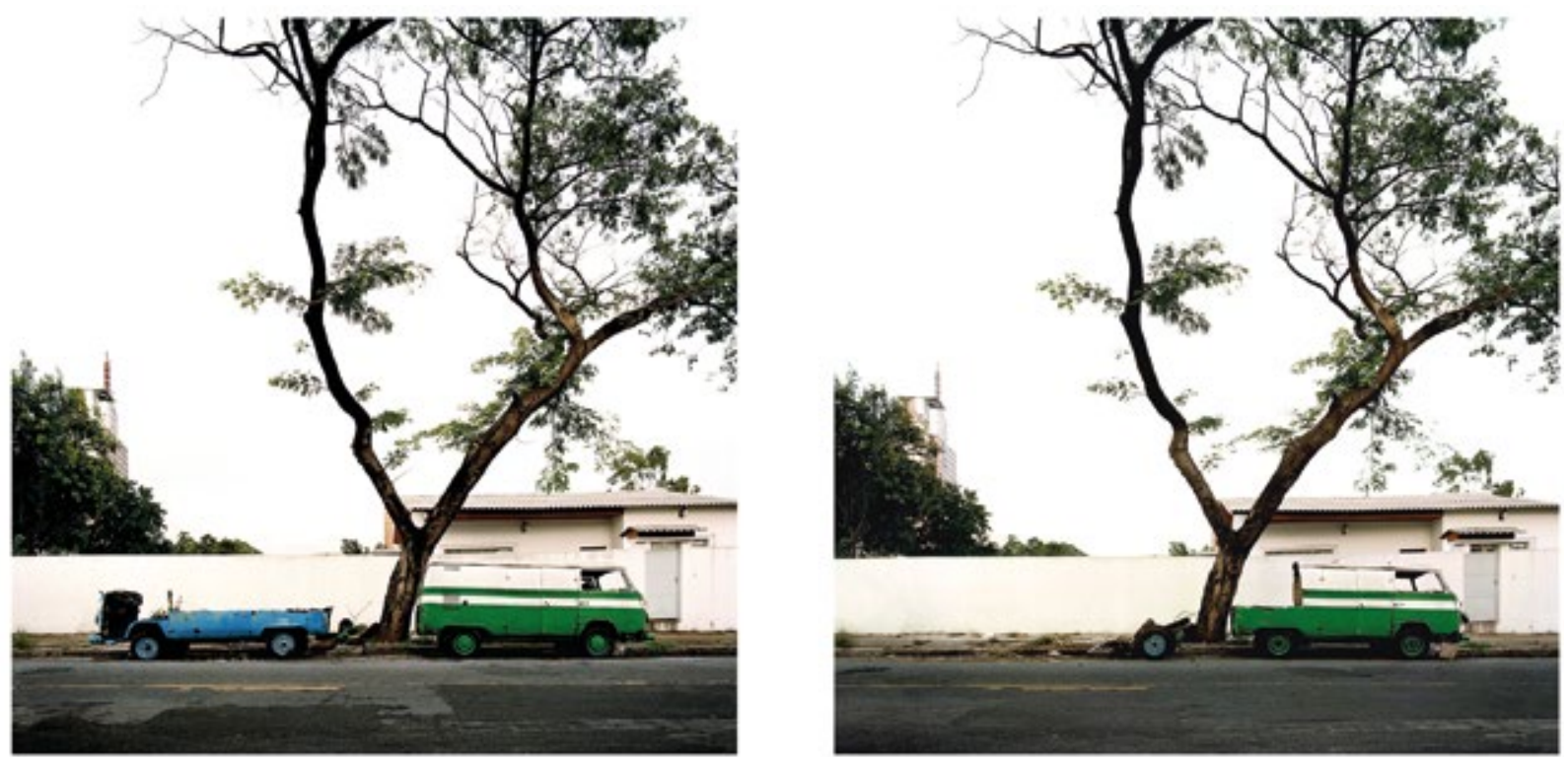
entre, 2003

díptico em fotografia, $143 \times 211 \times 3 \mathrm{~cm}$

(total); $143 \times 99 \times 3 \mathrm{~cm}$ (cada)

impressão lambda em papel RC

montada em metacrilato 

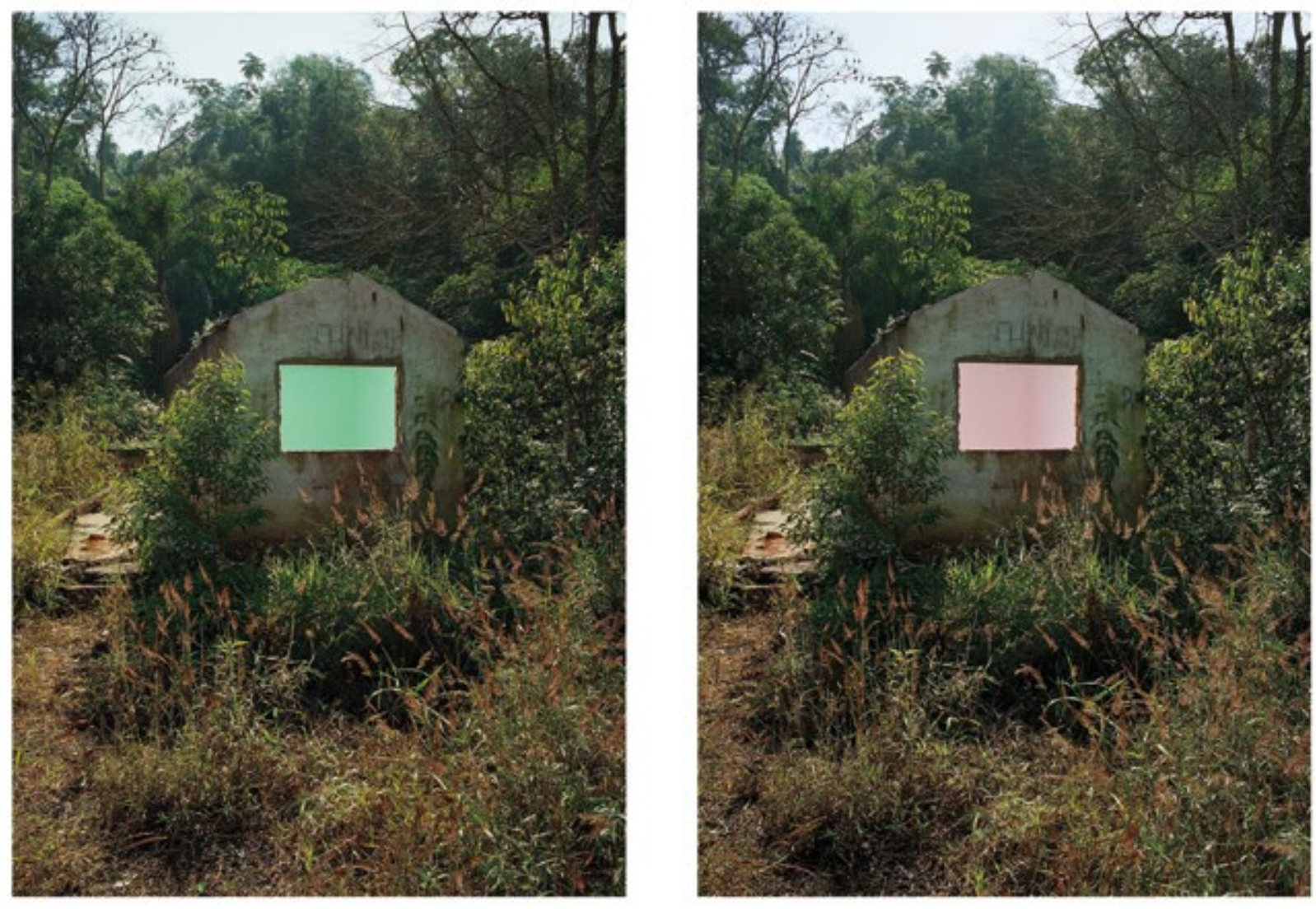
s/ título [serie súbitas paisagens] A, 2006 fotografia, $126 \times 133 \mathrm{~cm}$

impressão lambda em papel RC montada

em metacrilato

$14 \mid 15$ 


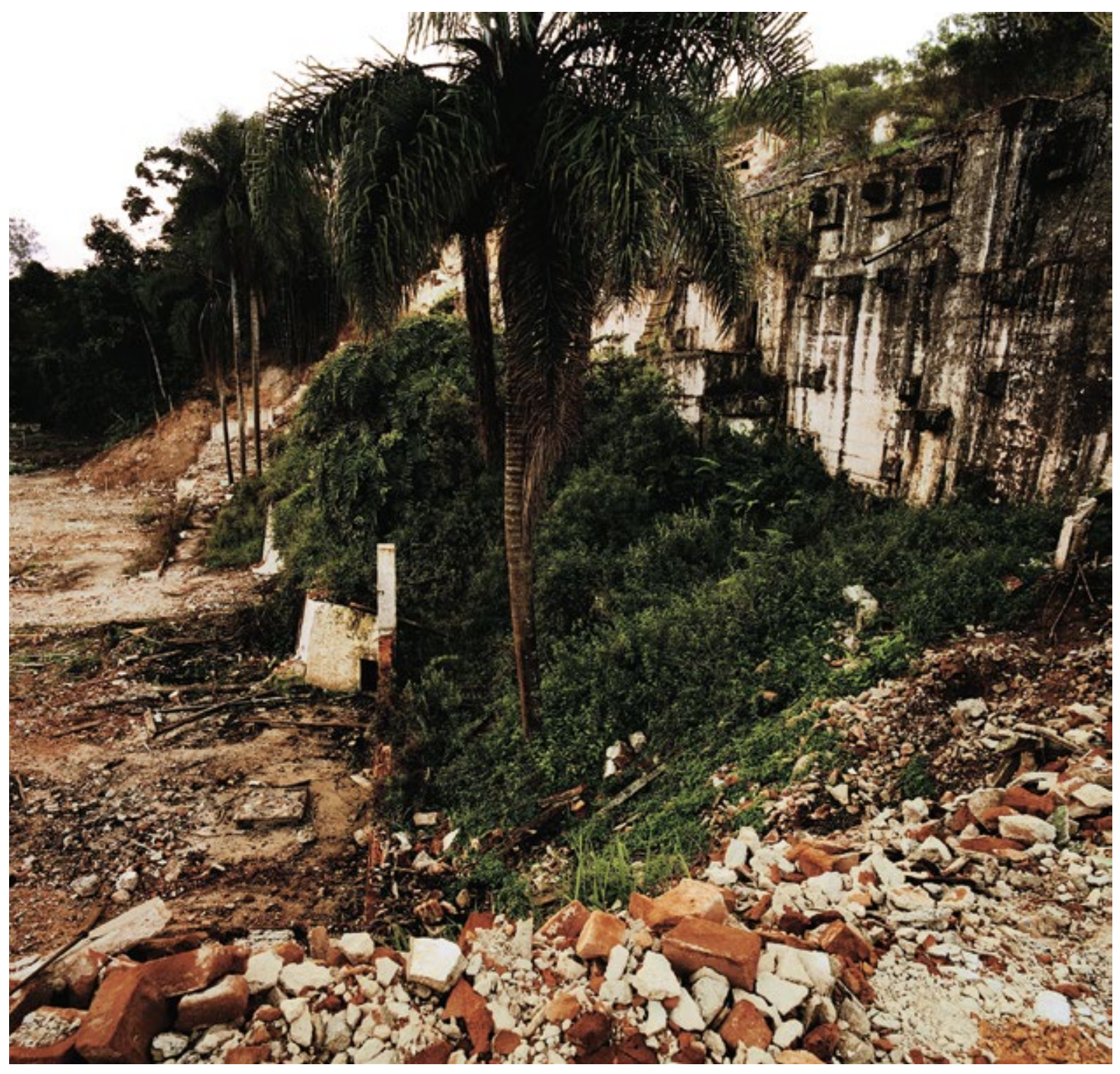


s/ título [serie súbitas paisagens] G, 2006 fotografia, $126 \times 132 \mathrm{~cm}$

impressão lambda em papel RC montada

em metacrilato

16 | 17 


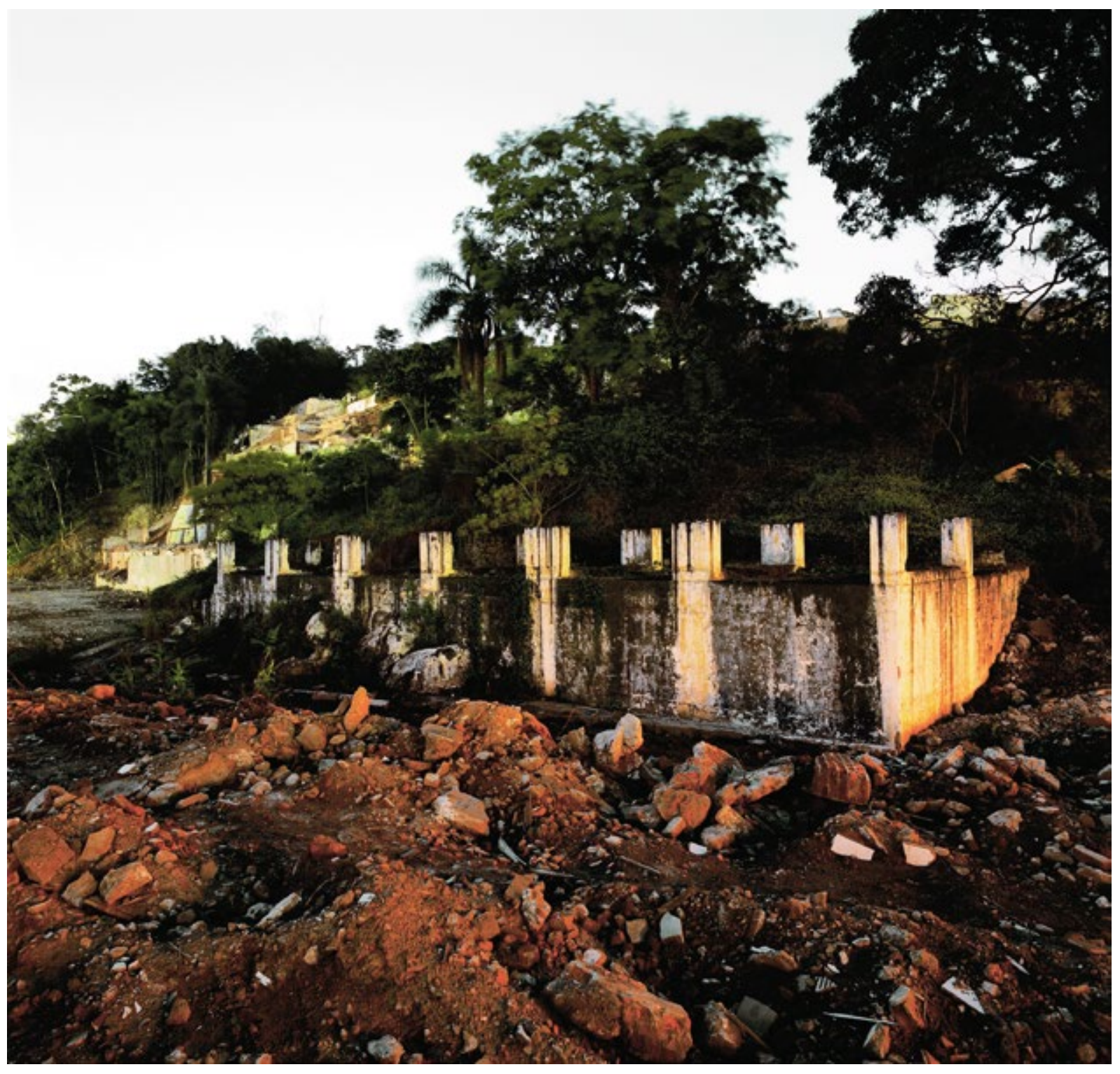


s/ título [serie súbitas paisagens] P, 2007 fotografia, $128 \times 136 \times 8 \mathrm{~cm}$

impressão lambda em papel RC montada

em metacrilato

18 | 19 


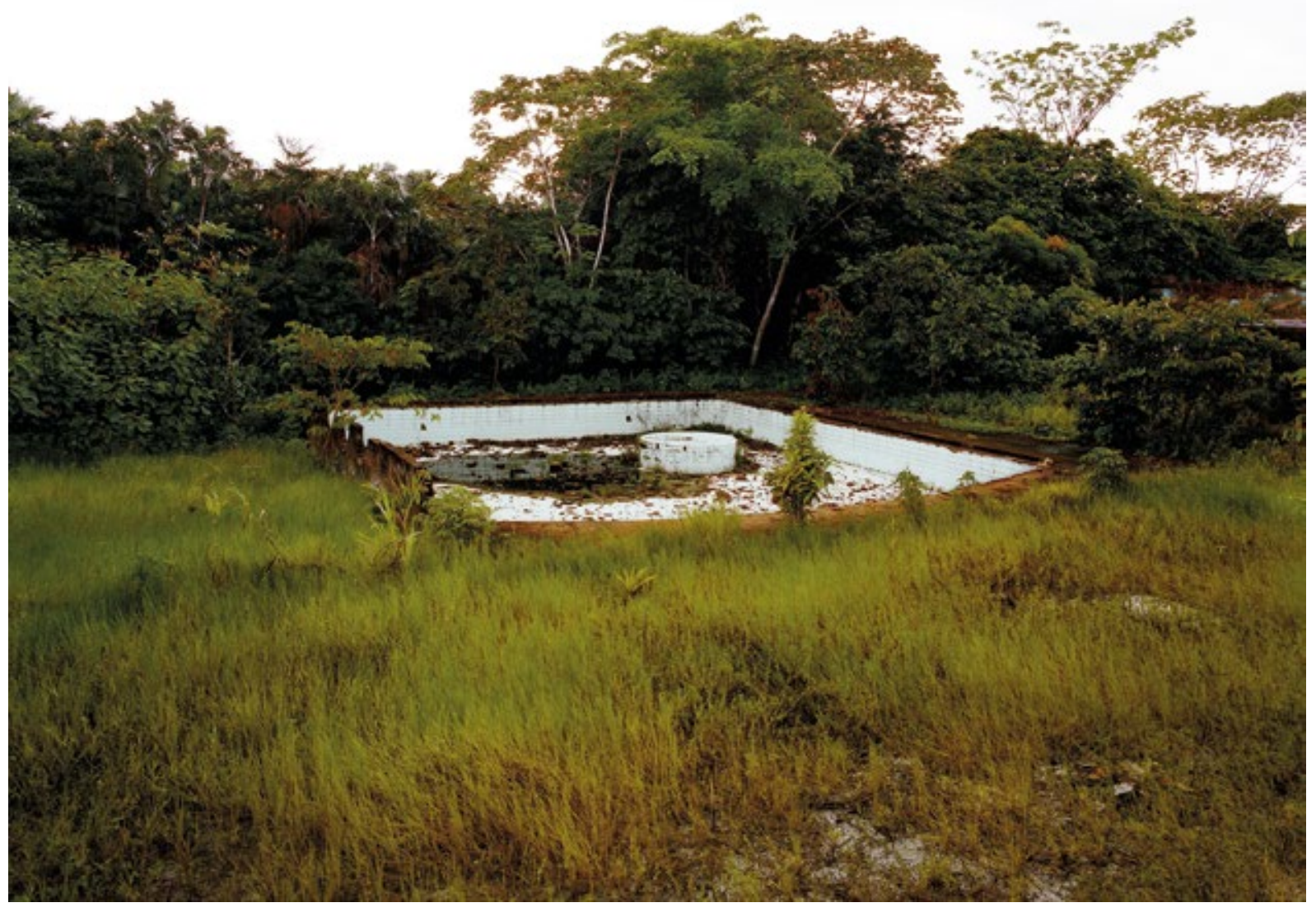


s/ título [serie súbitas paisagens] T, 2007

fotografia, $126 \times 205 \times 3 \mathrm{~cm}$

impressão lambda em papel RC montada

em metacrilato

$20 \mid 21$ 


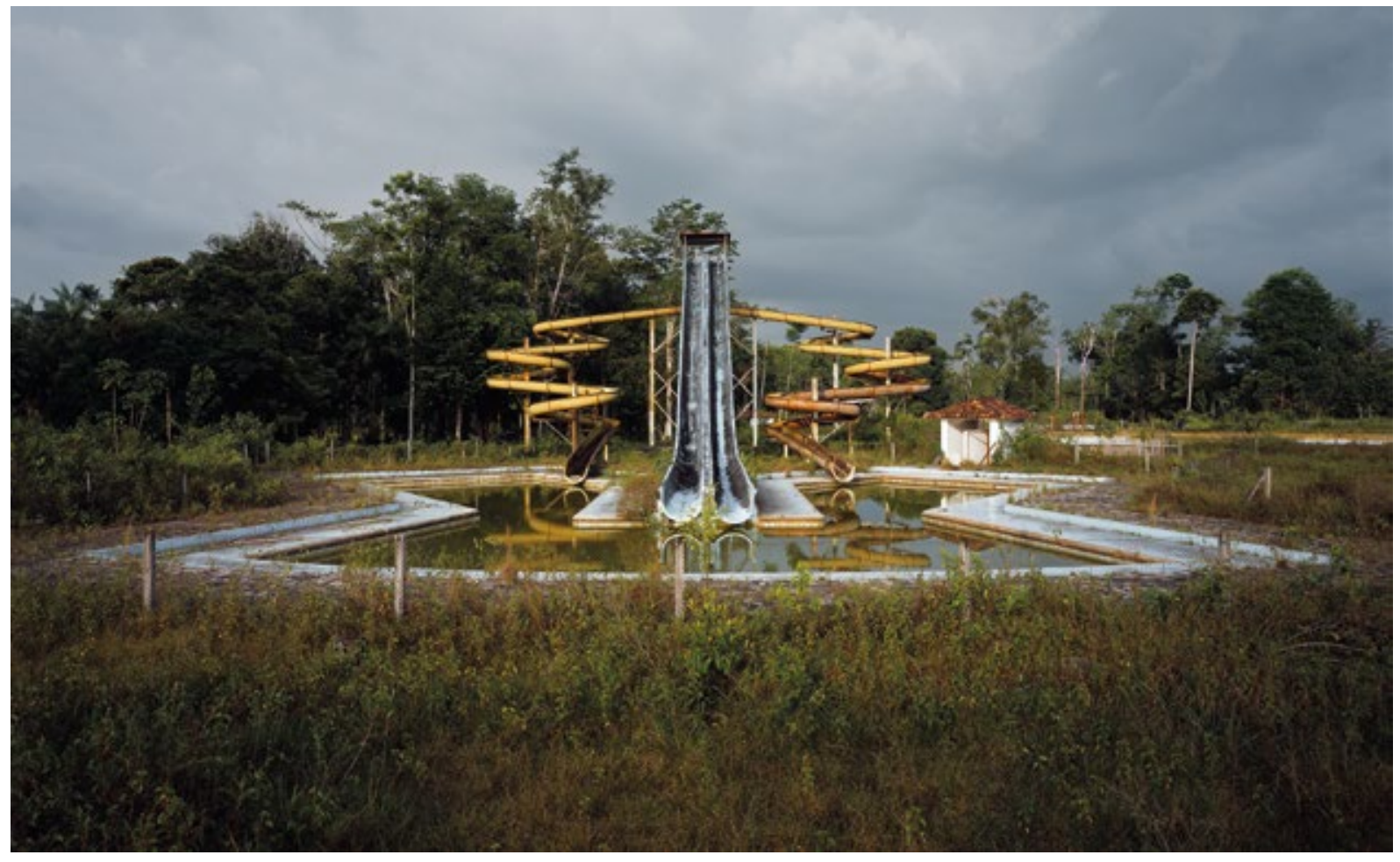


detetor de ausências, 1994

instalação com projetor sperry,

lâmpada HDMI, estrutura metálica,

estabilizador e cabo elétrico

Projeto Arte/Cidade2,

Vale do Anhangabaú, São Paulo 


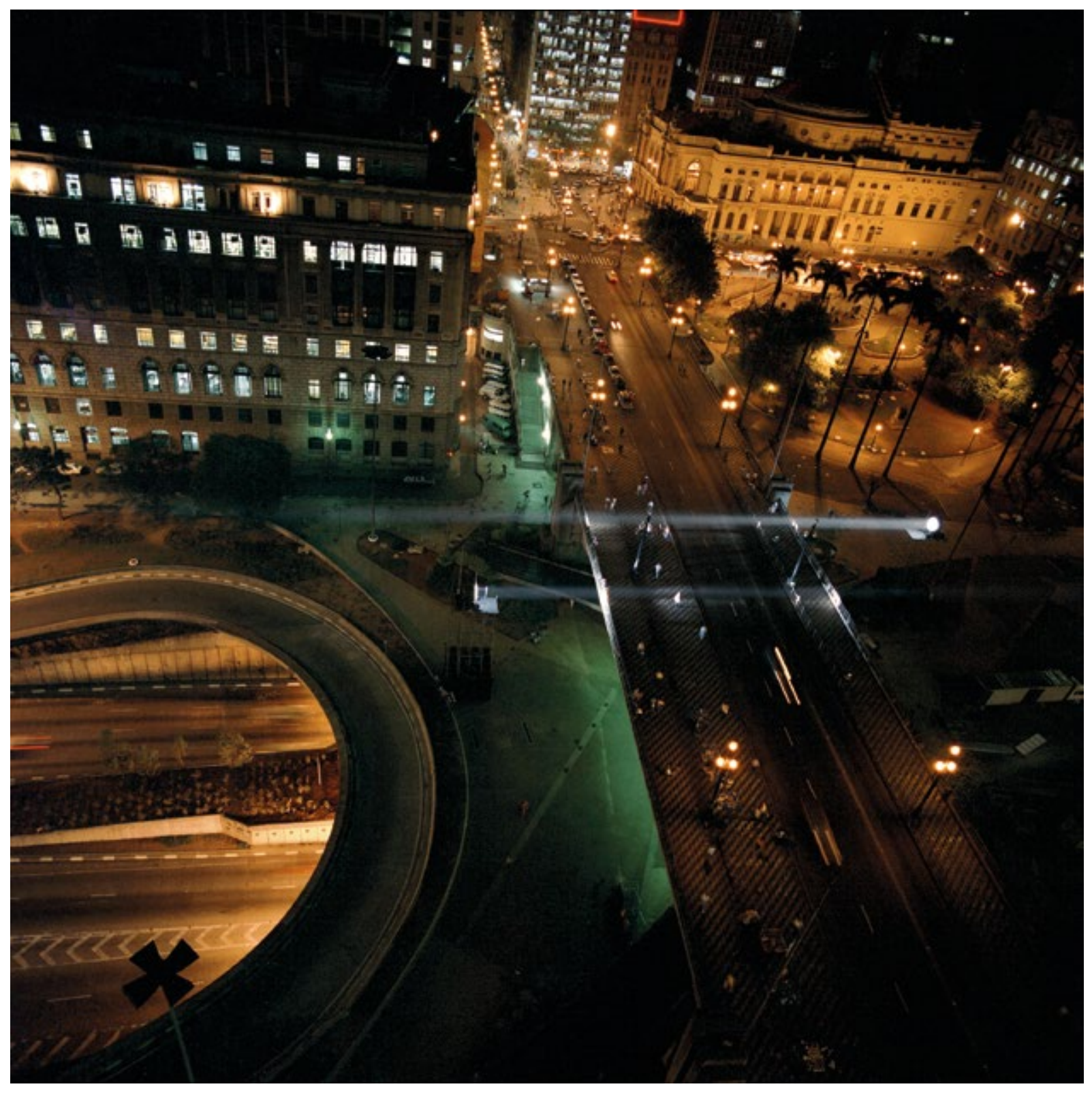


detetor de ausências, 1994

instalação com projetor sperry,

lâmpada HDMI, estrutura metálica,

estabilizador e cabo elétrico

Projeto Arte/Cidade2,

Vale do Anhangabaú, São Paulo 


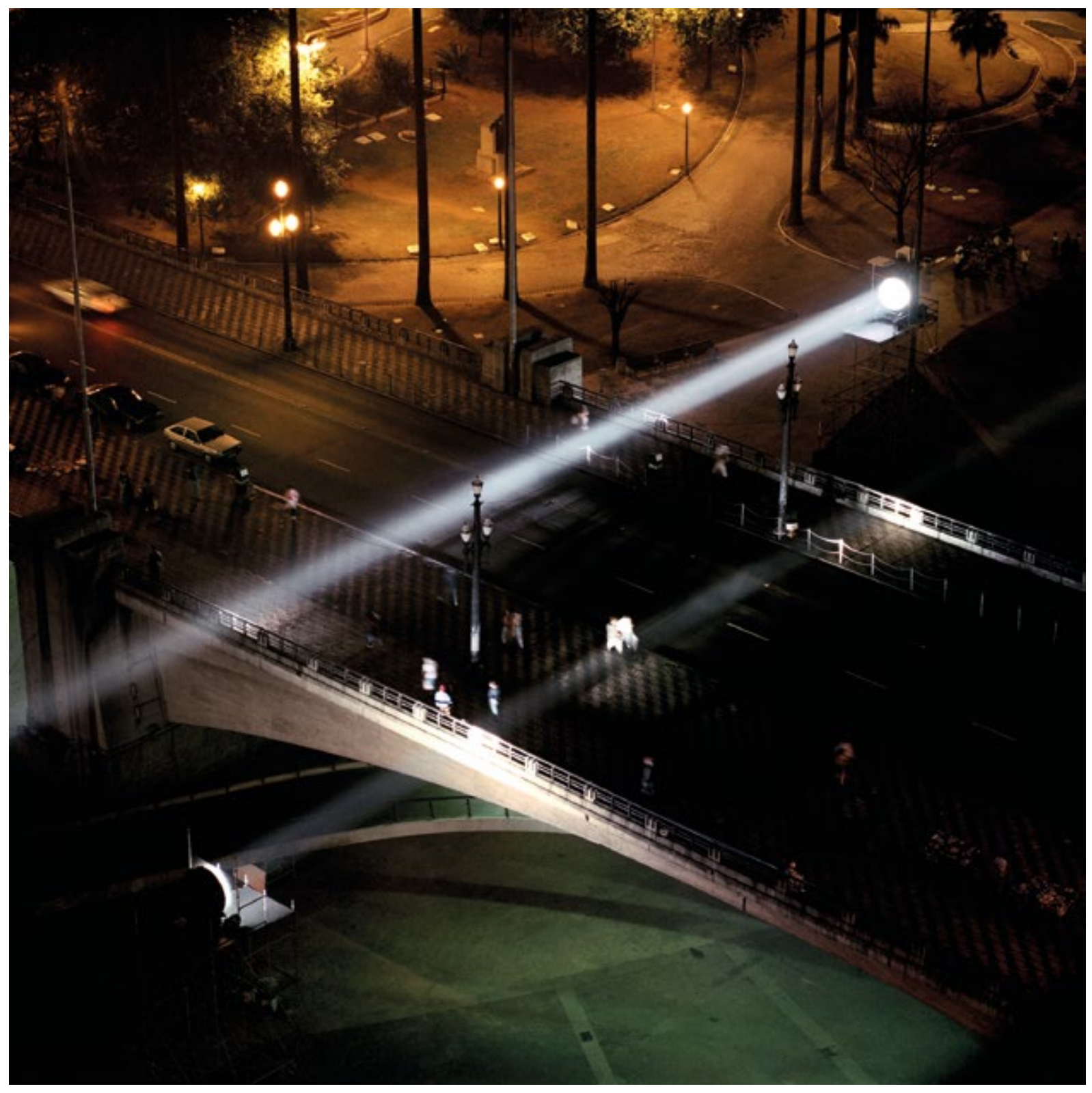


detetor de ausências, 1994

detalhe da intervenção com

um dos focos de luz

Vista do Viaduto do Chá a partir

do Vale do Anhambabaú, São Paulo 


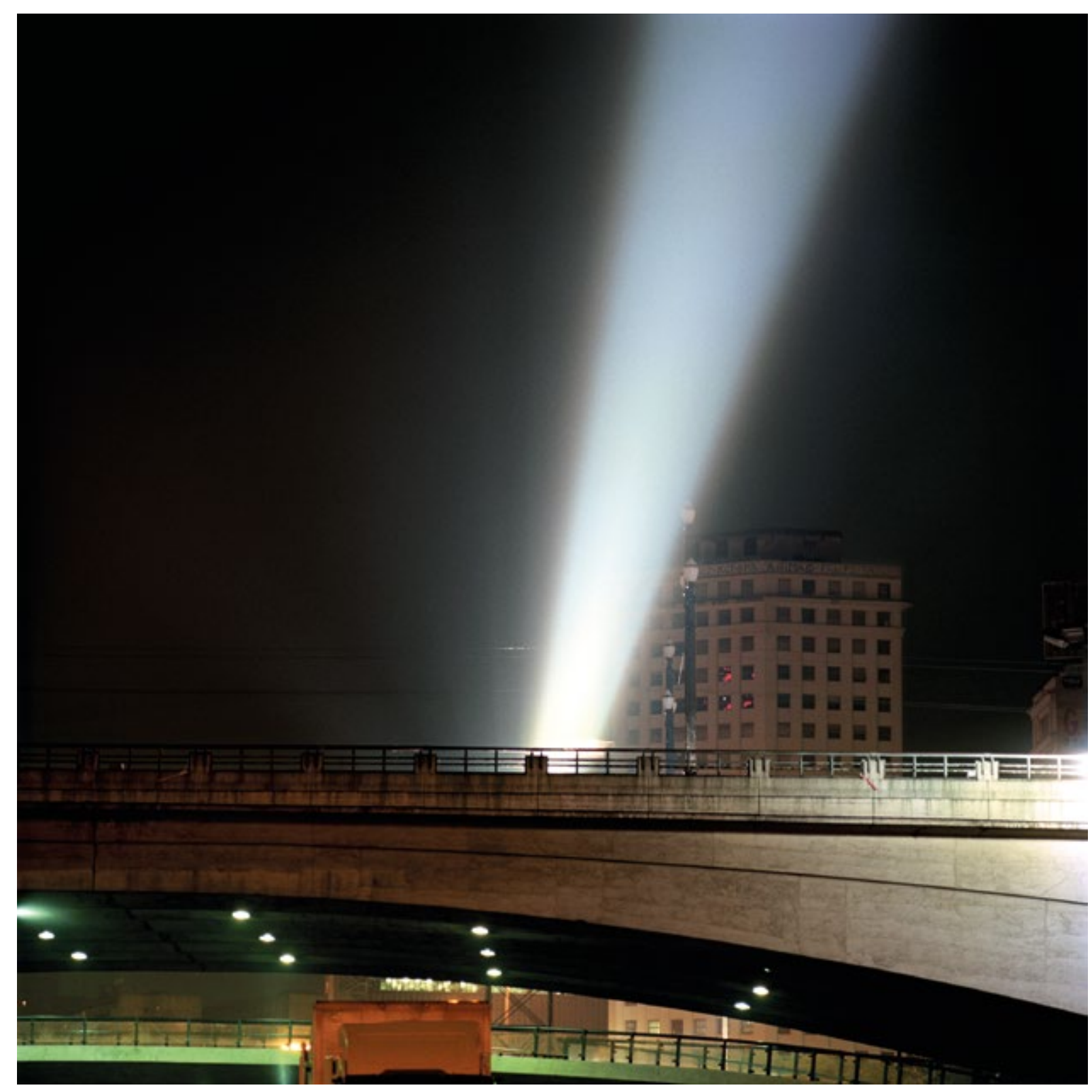




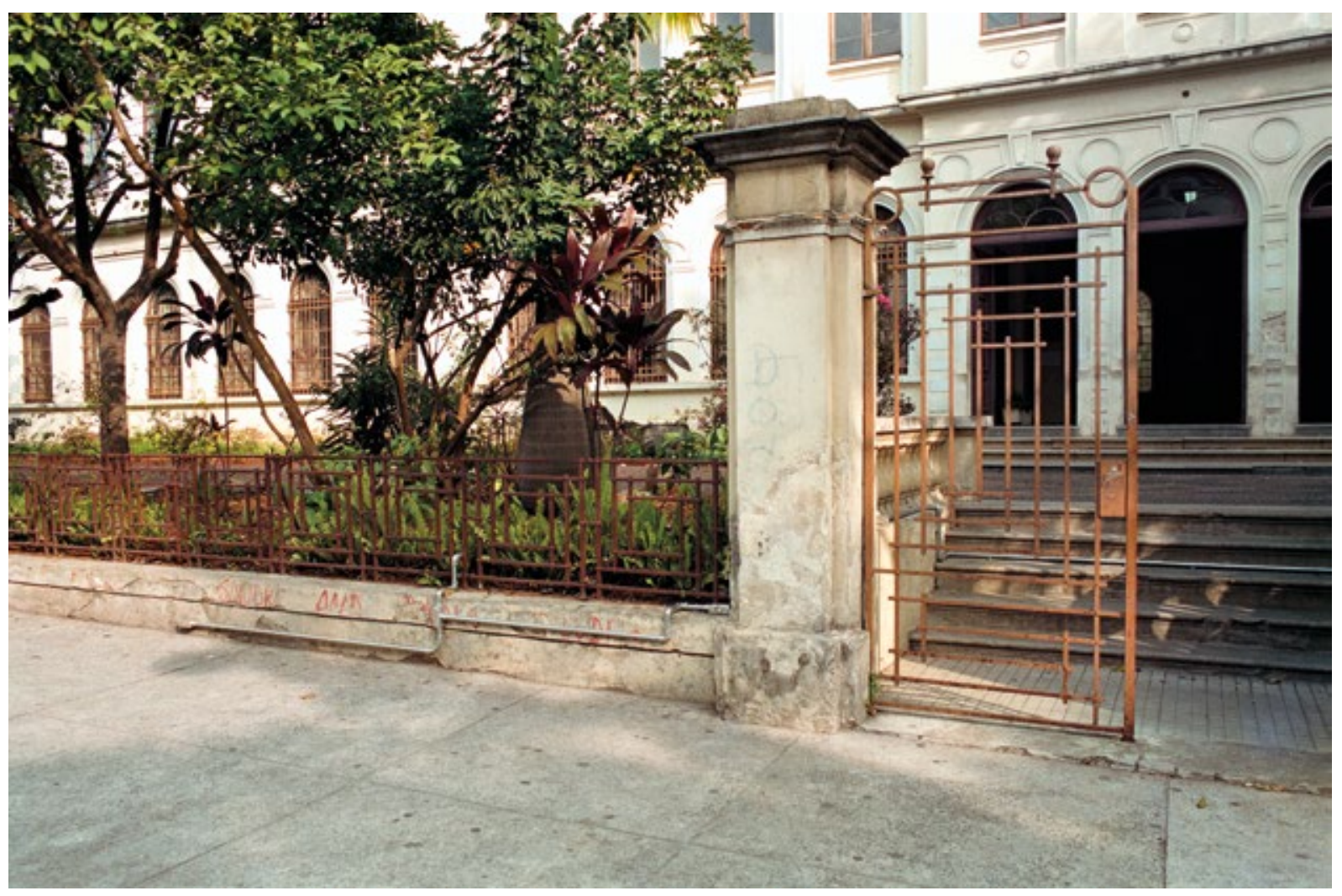

calçada, 1999

instalação com tubo de metal, cabo elétrico, tomada, caixa, abraçadeira e cotovelo de alumínio Exposição f:(lux)os, Oficina Cultural Oswald de Andrade, São Paulo 


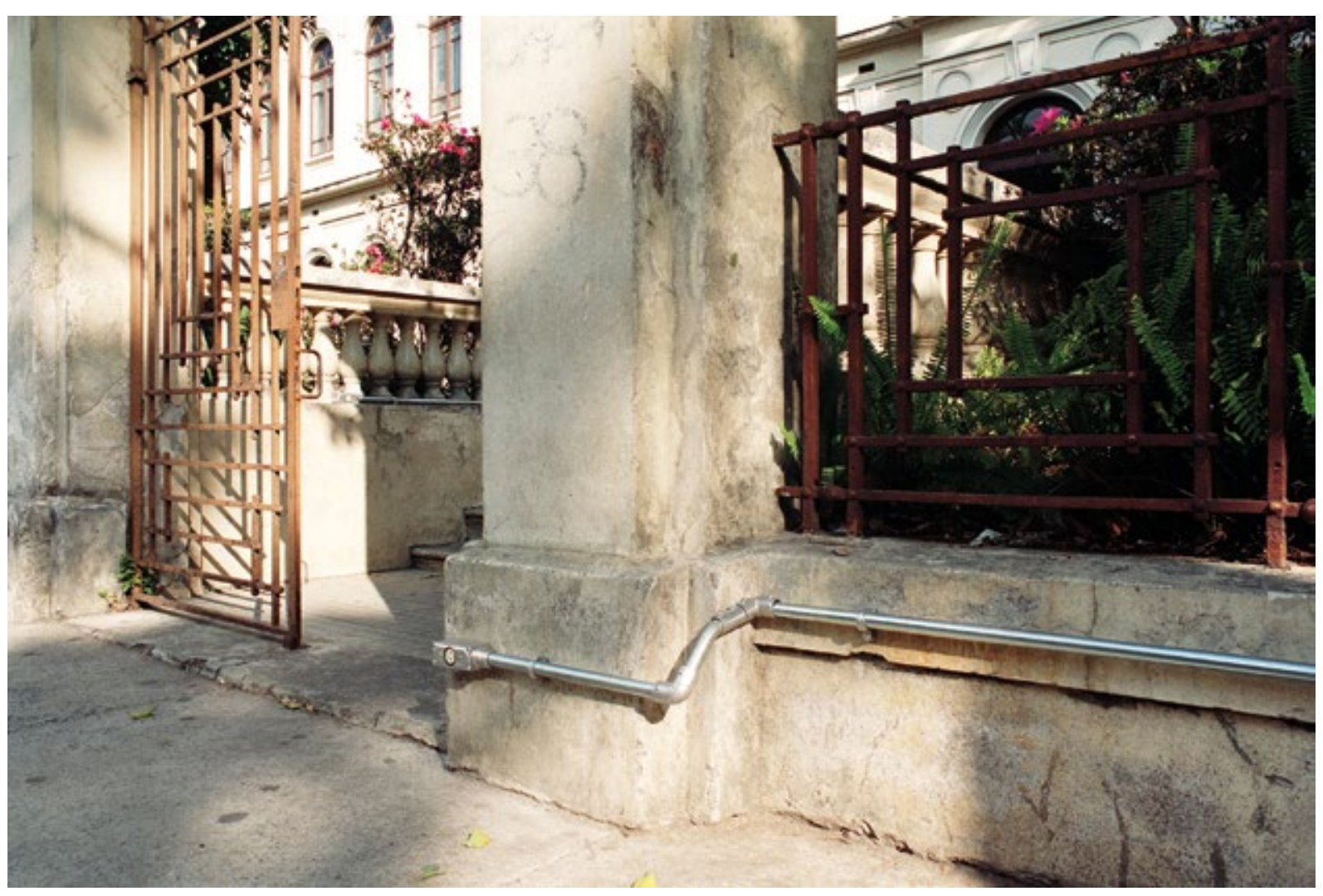


(1)

calçada, 1999

detalhe da instalação com tomadas eletrificadas

$30 \mid 31$ 


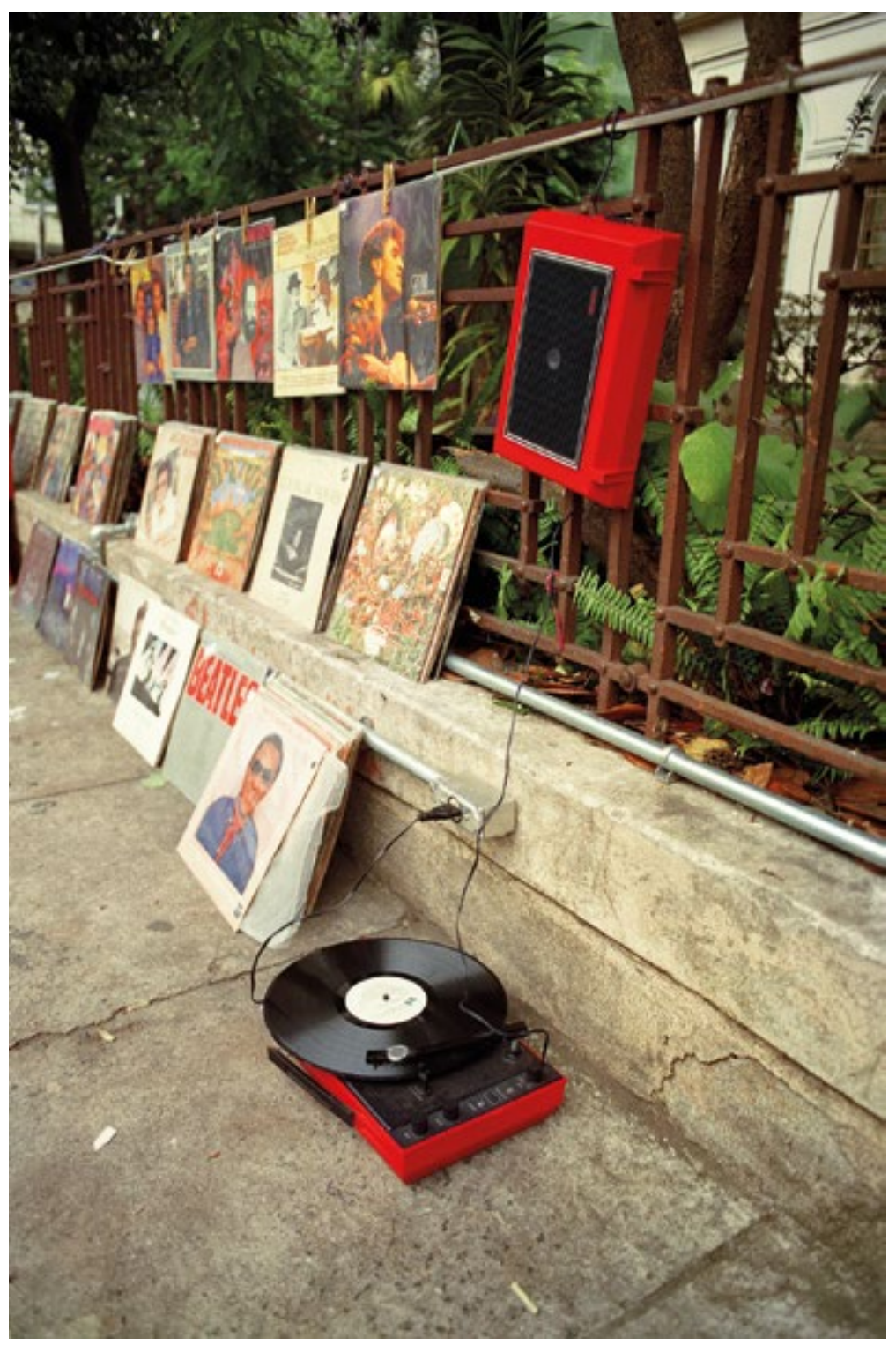


vazadores, 2002 [projeto não realizado]

intervenção com corte na laje, grade alveolar de aço carbono e cinta de ferro projeto de instalação para o segundo andar do Pavilhão Ciccillo Matarazzo, $25^{\text {a }}$ Bienal de São Paulo 


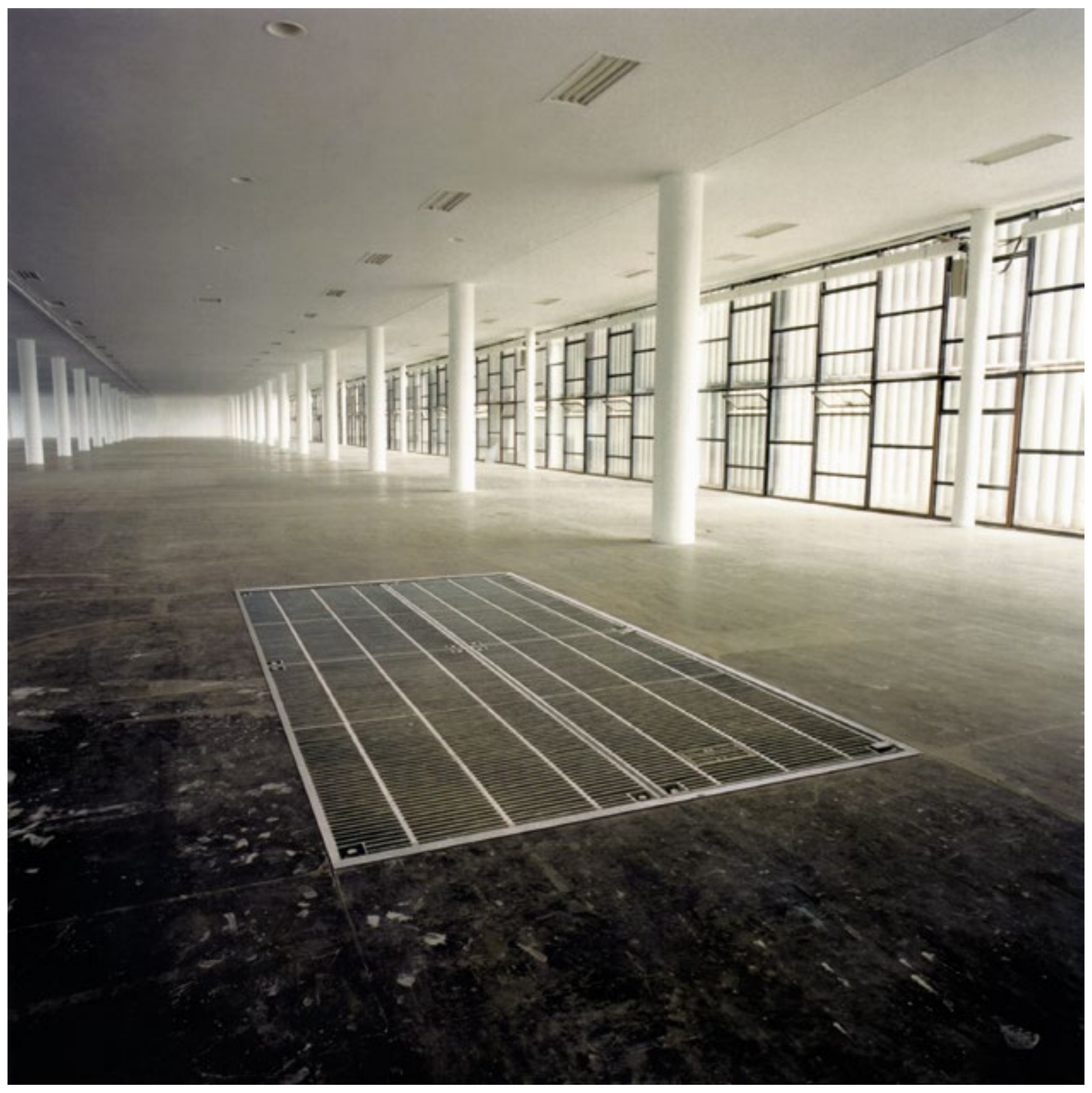


vazadores, 2002

intervenção com estrutura metálica, vidro, câmera de segurança

e gravador de vídeo

pavimento térreo do Pavilhão Ciccillo

Matarazzo, 25ª Bienal de São Paulo

34 | 35 


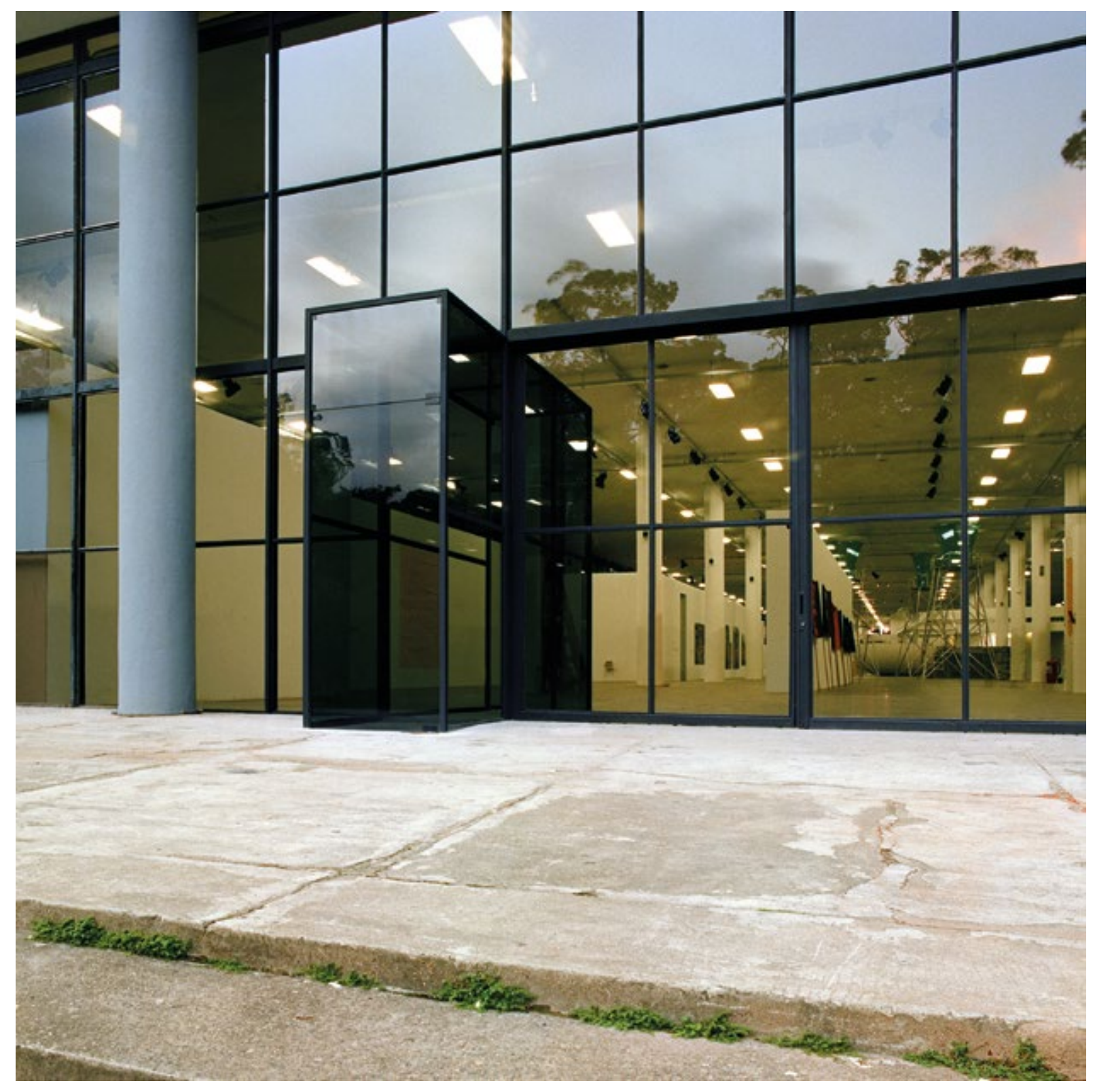


vazadores, 2002

intervenção com estrutura metálica, vidro, câmera de segurança

e gravador de vídeo

pavimento térreo do Pavilhão Ciccillo

Matarazzo, 25ª Bienal de São Paulo

$36 \quad 37$ 


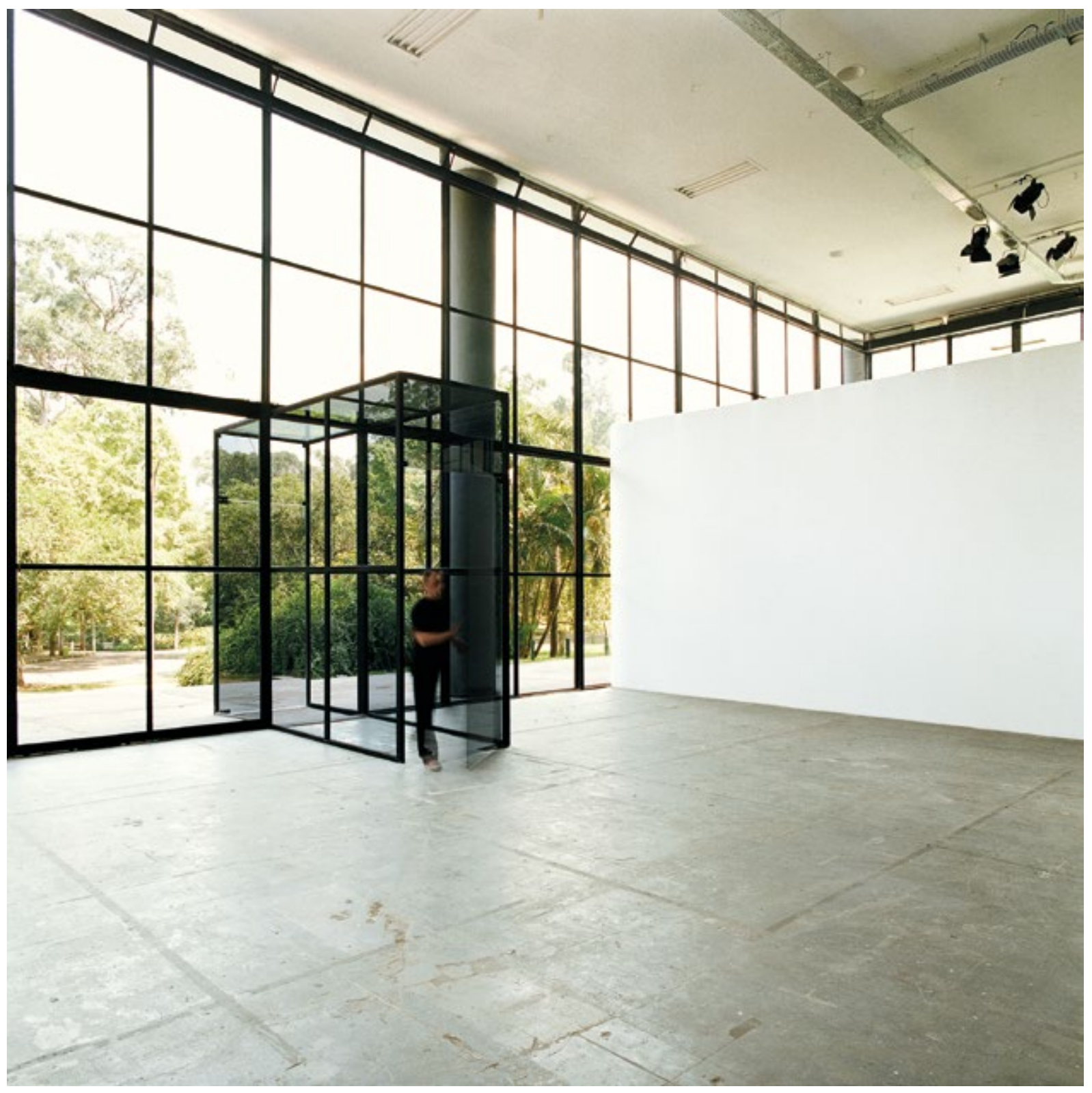


vazadores, 2002

mesa, cadeiras, monitor de vídeo

e guarda de segurança (continuação da intervenção do térreo)

segundo pavimento do Pavilhão Ciccillo

Matarazzo, 25ª Bienal de São Paulo 

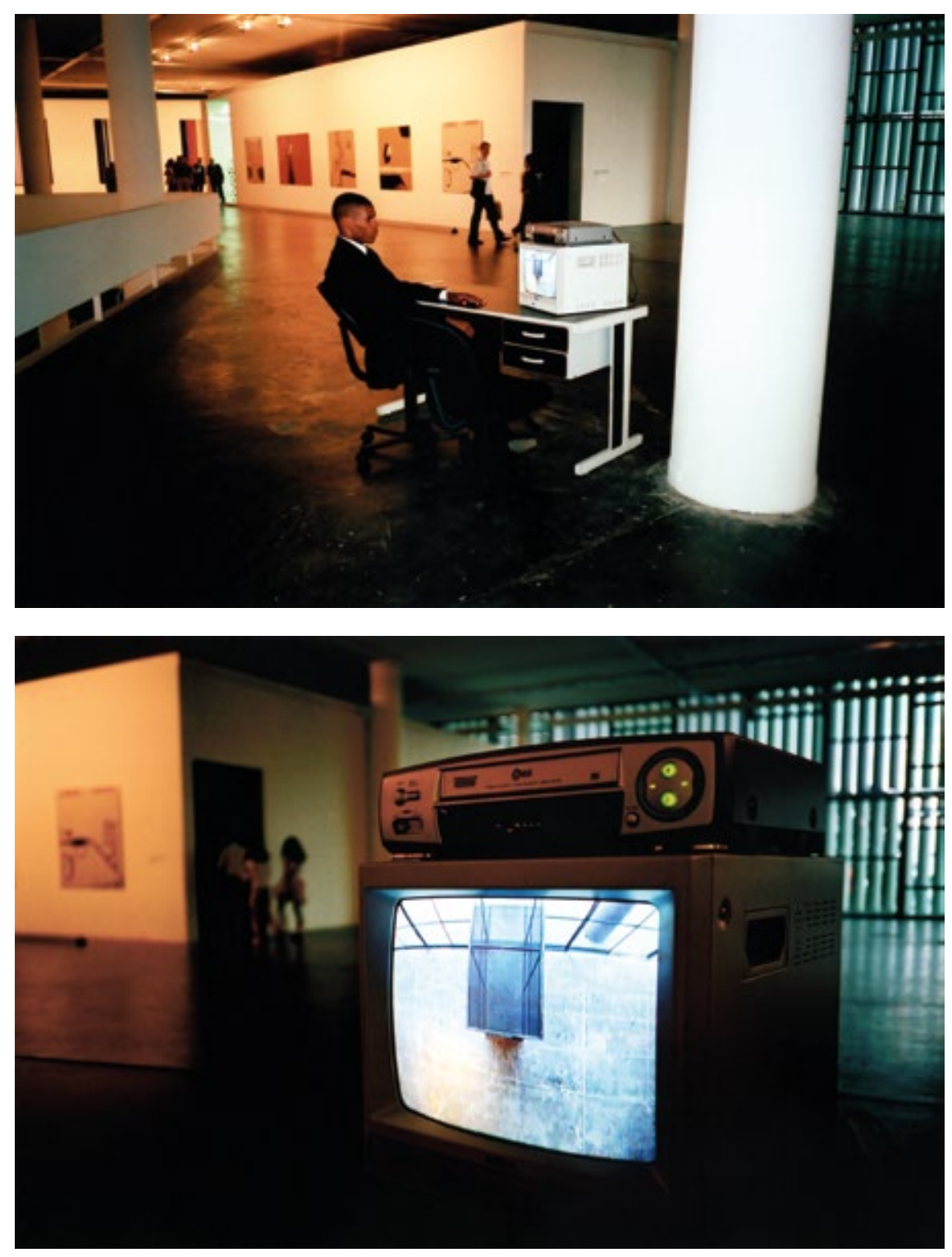


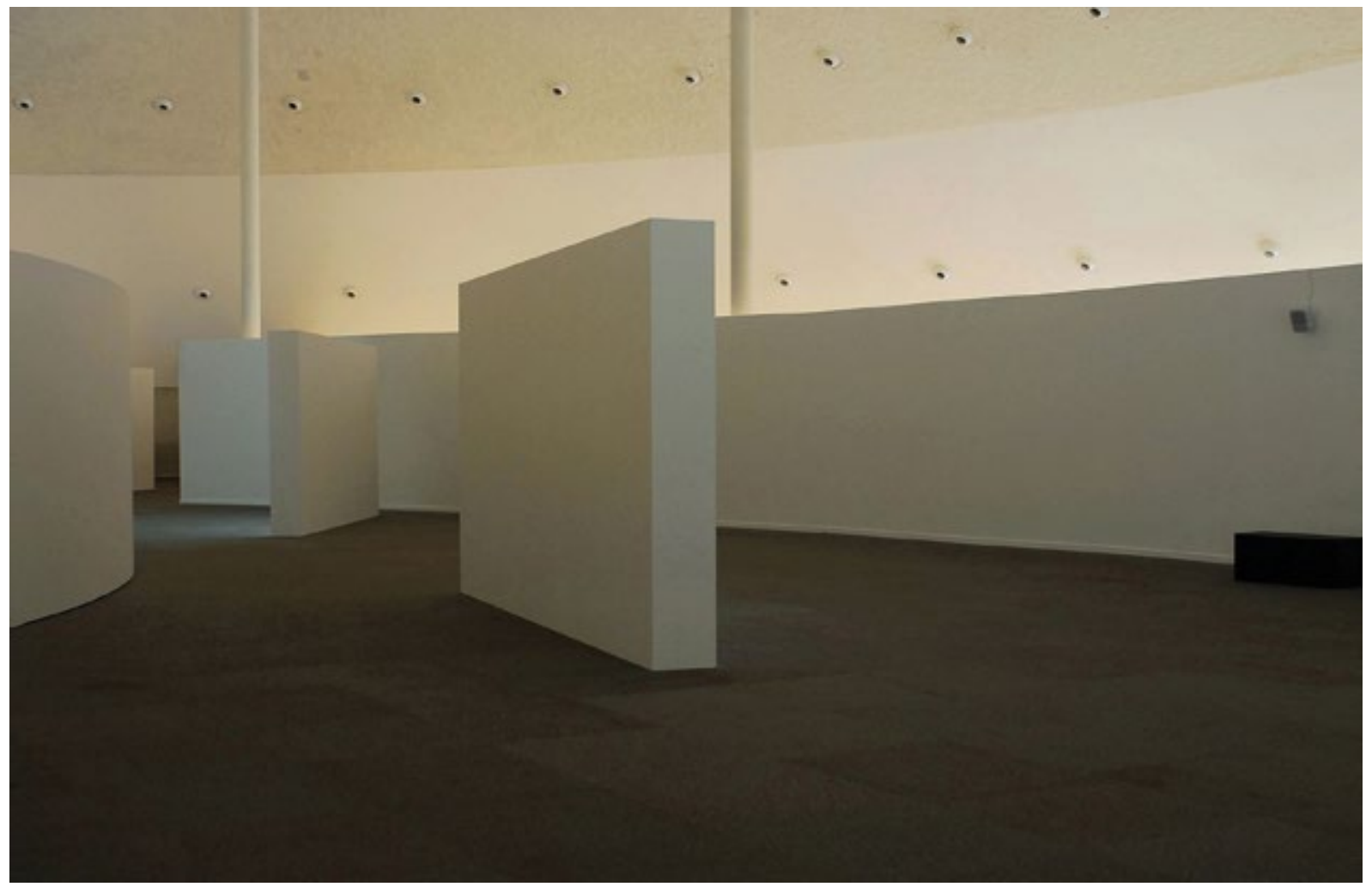

futuro do pretérito, 2010

videoinstalação [35' e 40' em loop] painéis de madeira autoportantes, projetores de vídeo e sistema de som Museu Nacional Honestino Guimarães, Brasília 


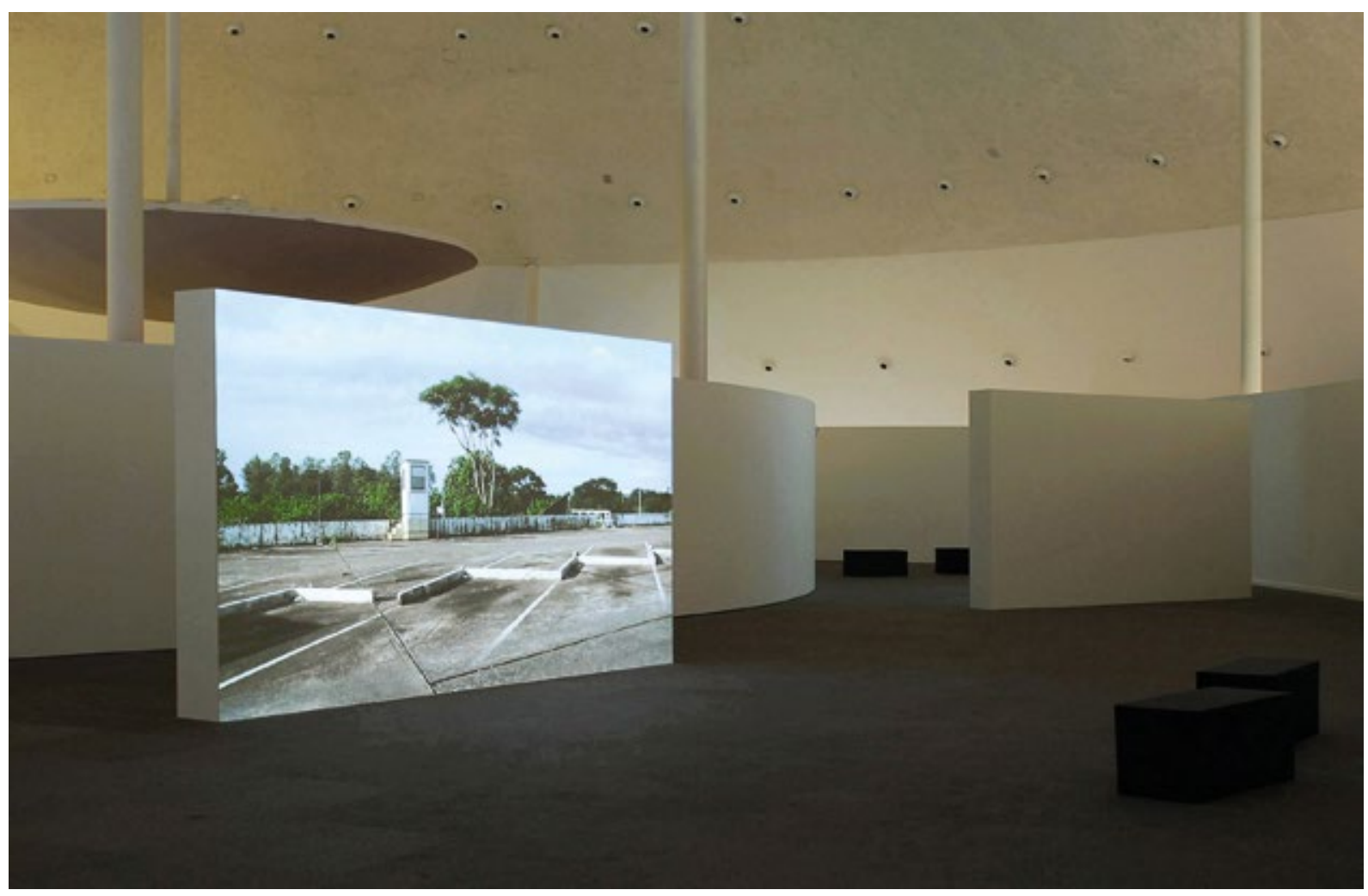


futuro do pretérito, 2010

stills de vídeo [plano piloto]

42 | 43 

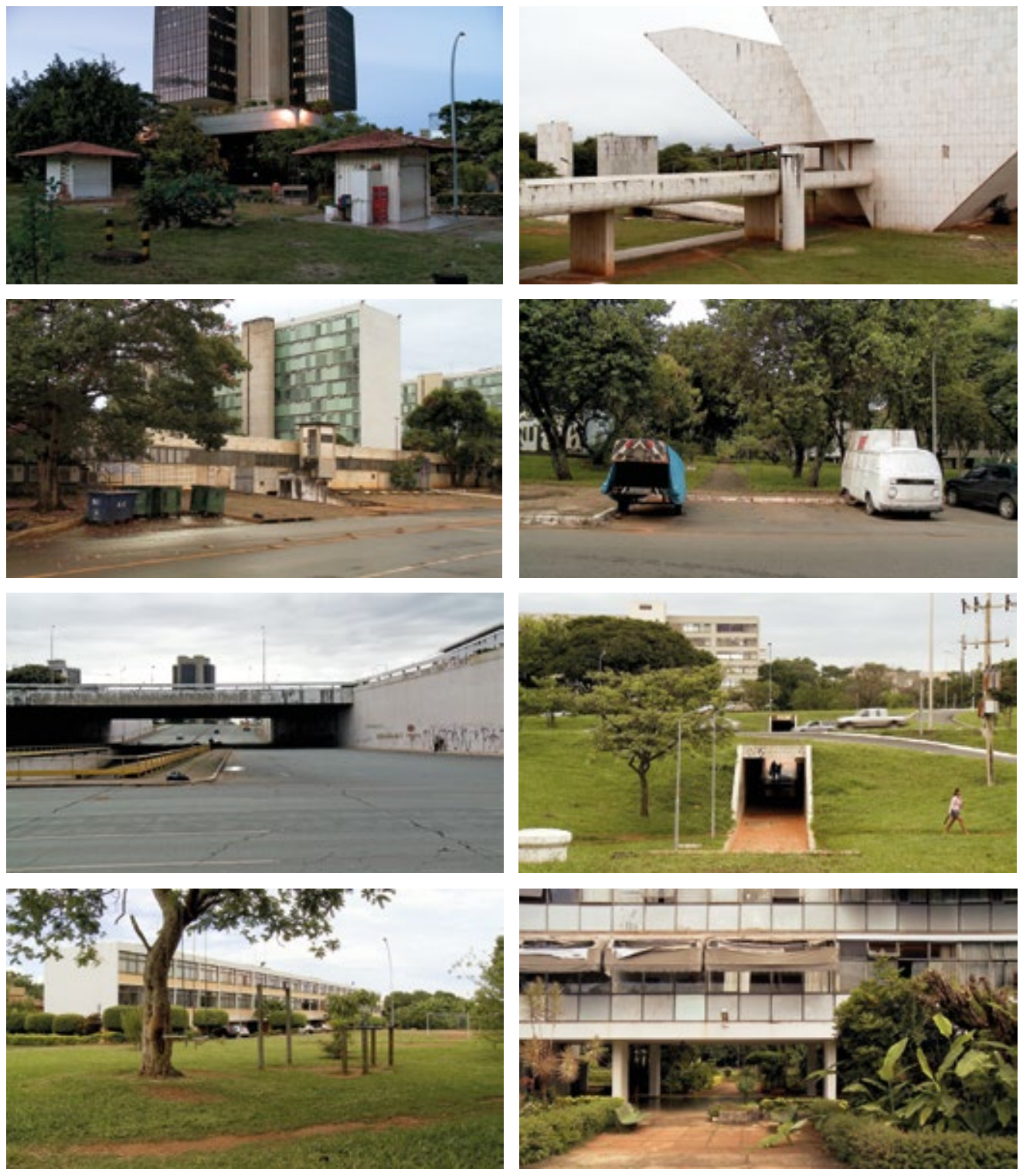
futuro do pretérito, 2010

stills de vídeo [cidades-satélites]

$44 \mid 45$ 

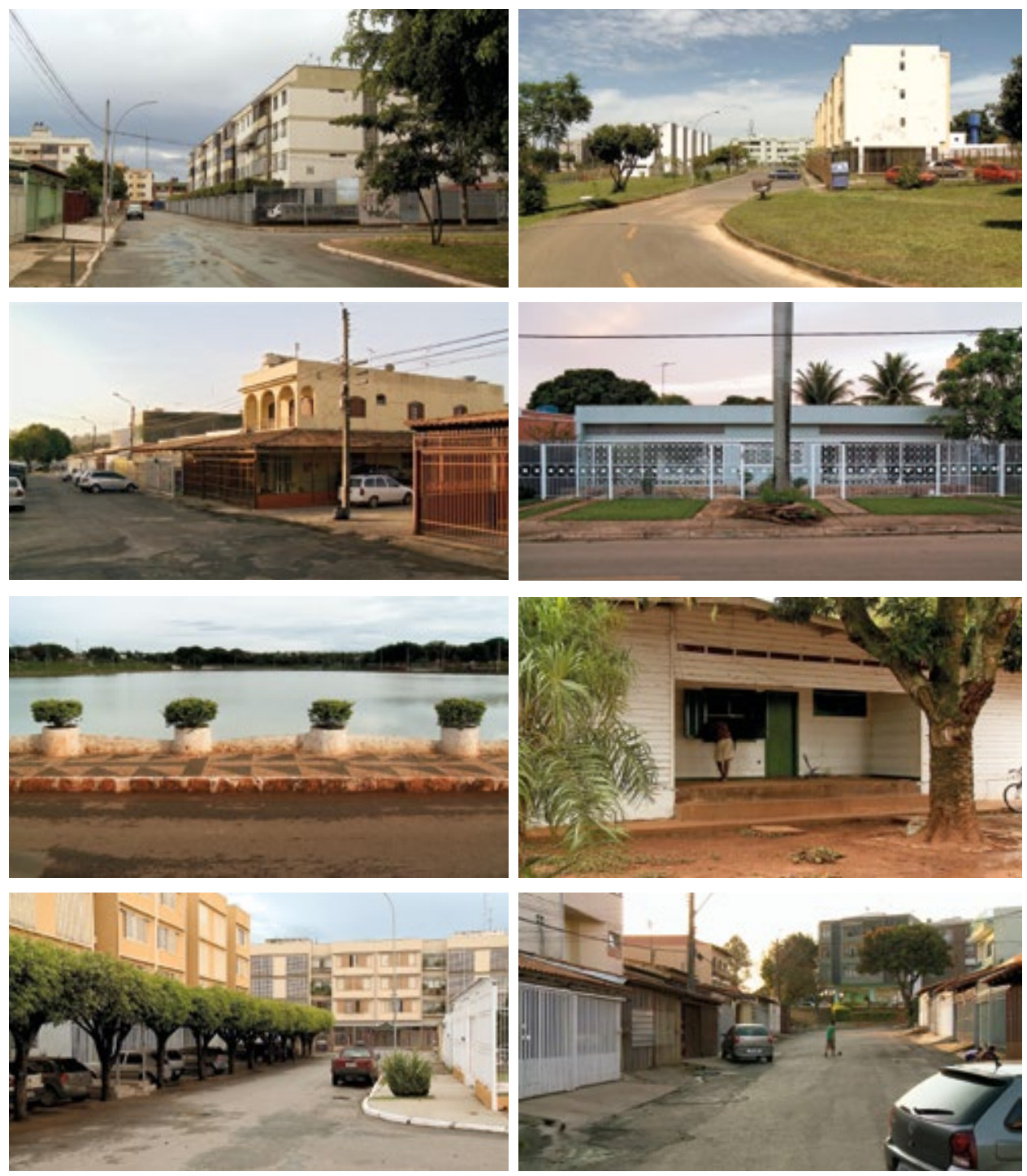


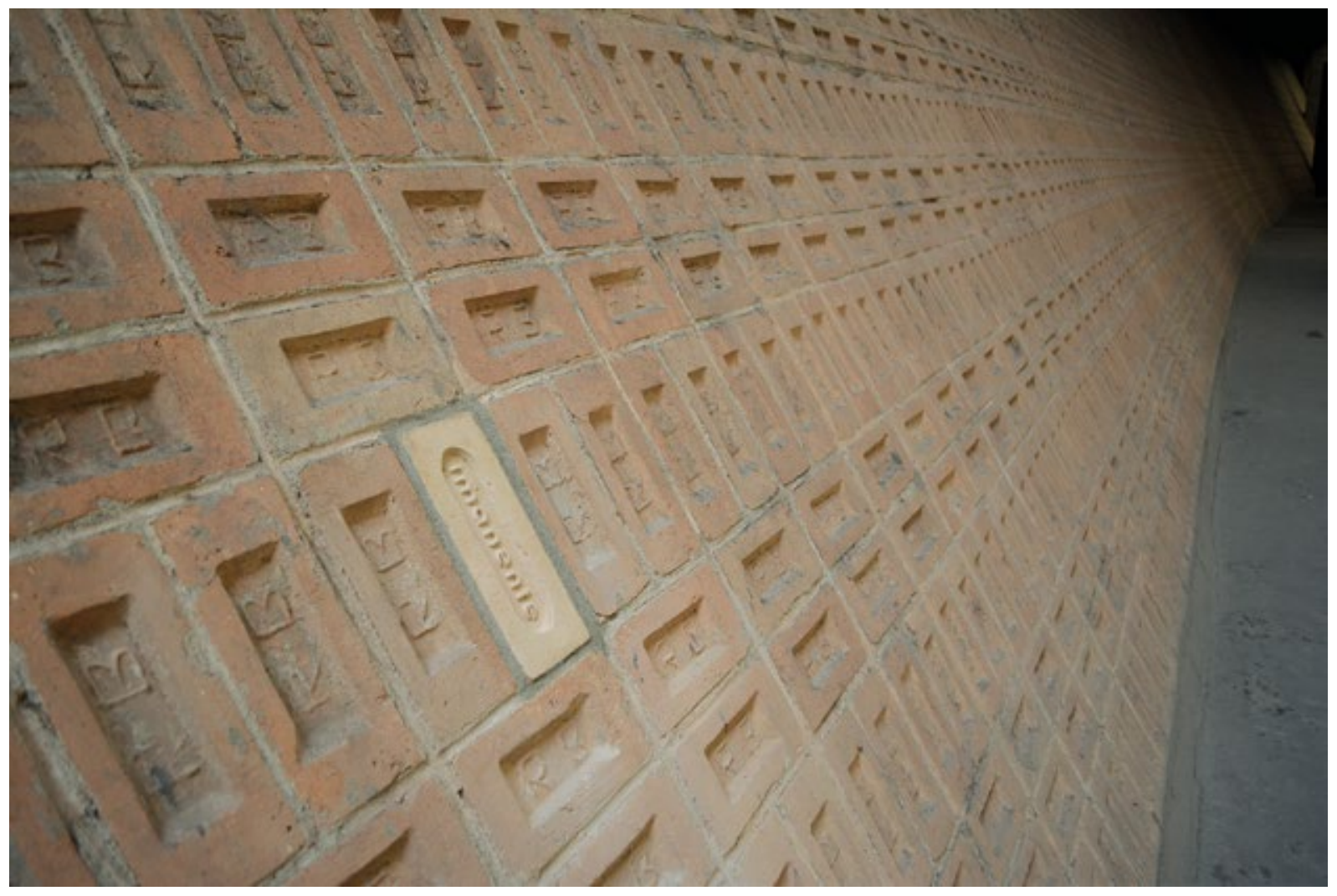

imanente [adição_multiplicação_

divisão_subtração_], 2014

intervenção com tijolo sobre parede, câmera de vídeo e monitor Artista convidado da Mostra do

Programa de Exposições 2014, Centro Cultural São Paulo 


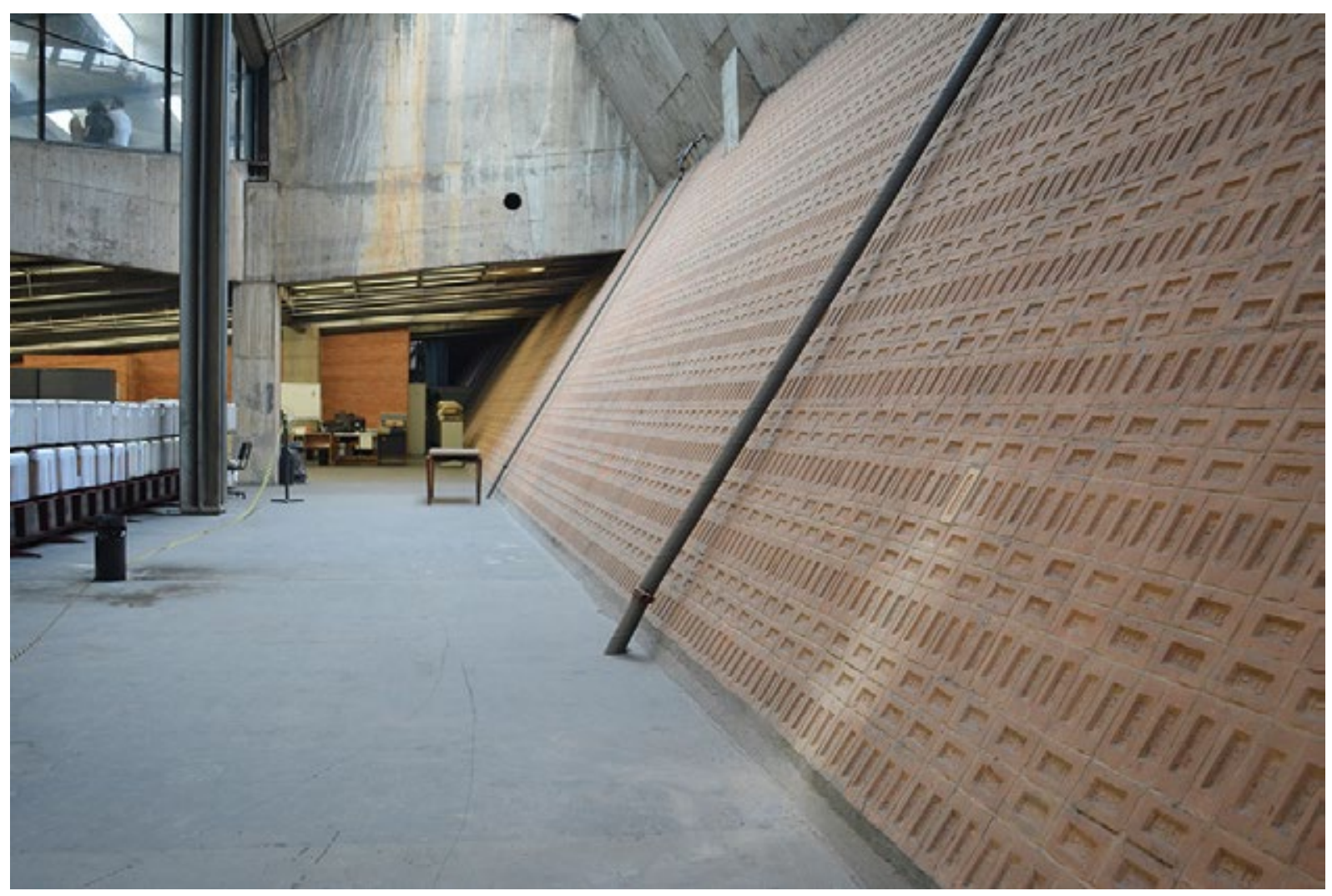


imanente [adição_multiplicação_

divisão_subtração_], 2014

vista da instalação com a câmera

de vídeo

$48 \mid 49$ 


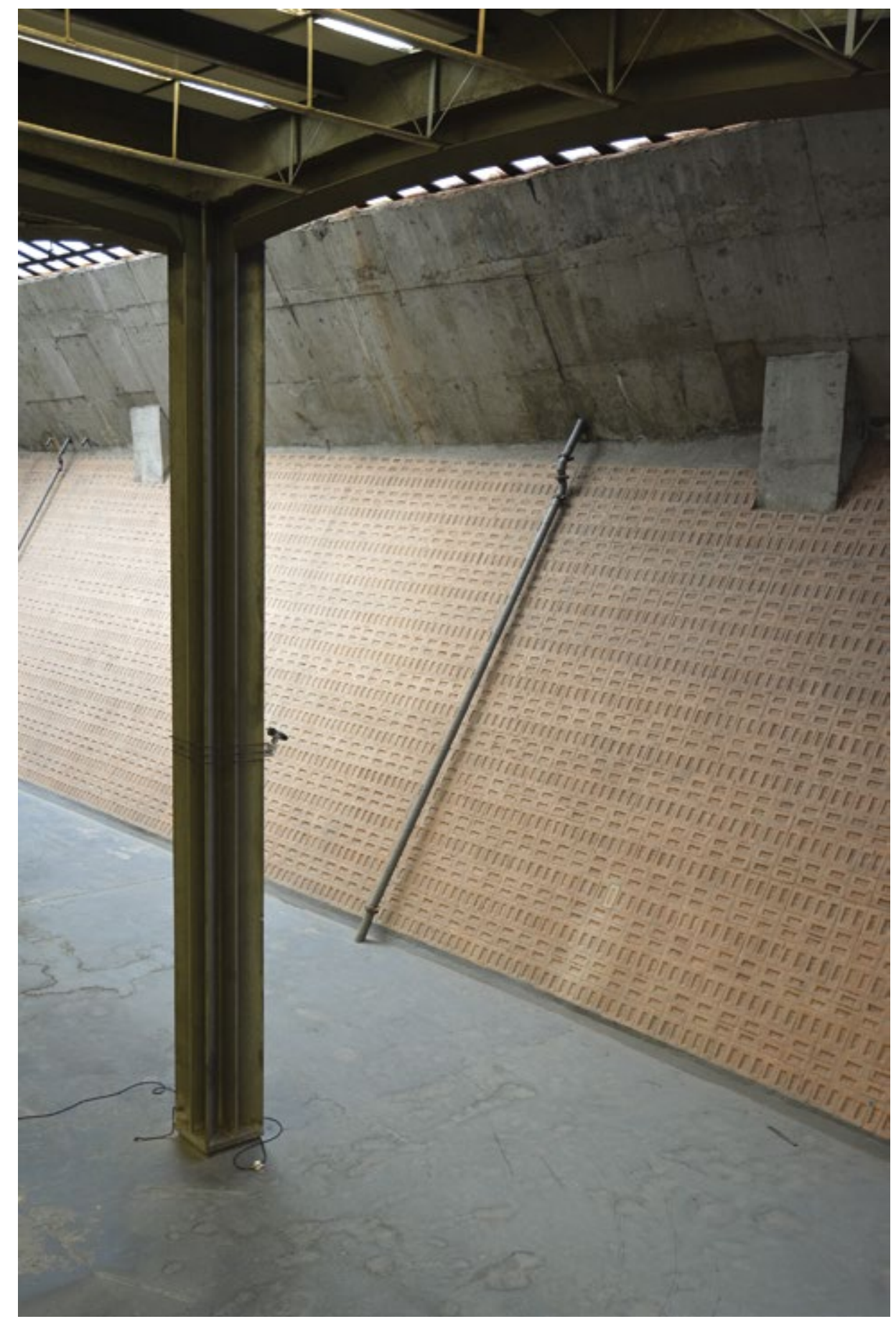


imanente [adição_multiplicação_

divisão_subtração_], 2014

detalhe da instalação com tijolos

antigos e videowall ao fundo

Vista da exposição no Piso Caio Graco,

Centro Cultural São Paulo

$50 \mid 51$ 


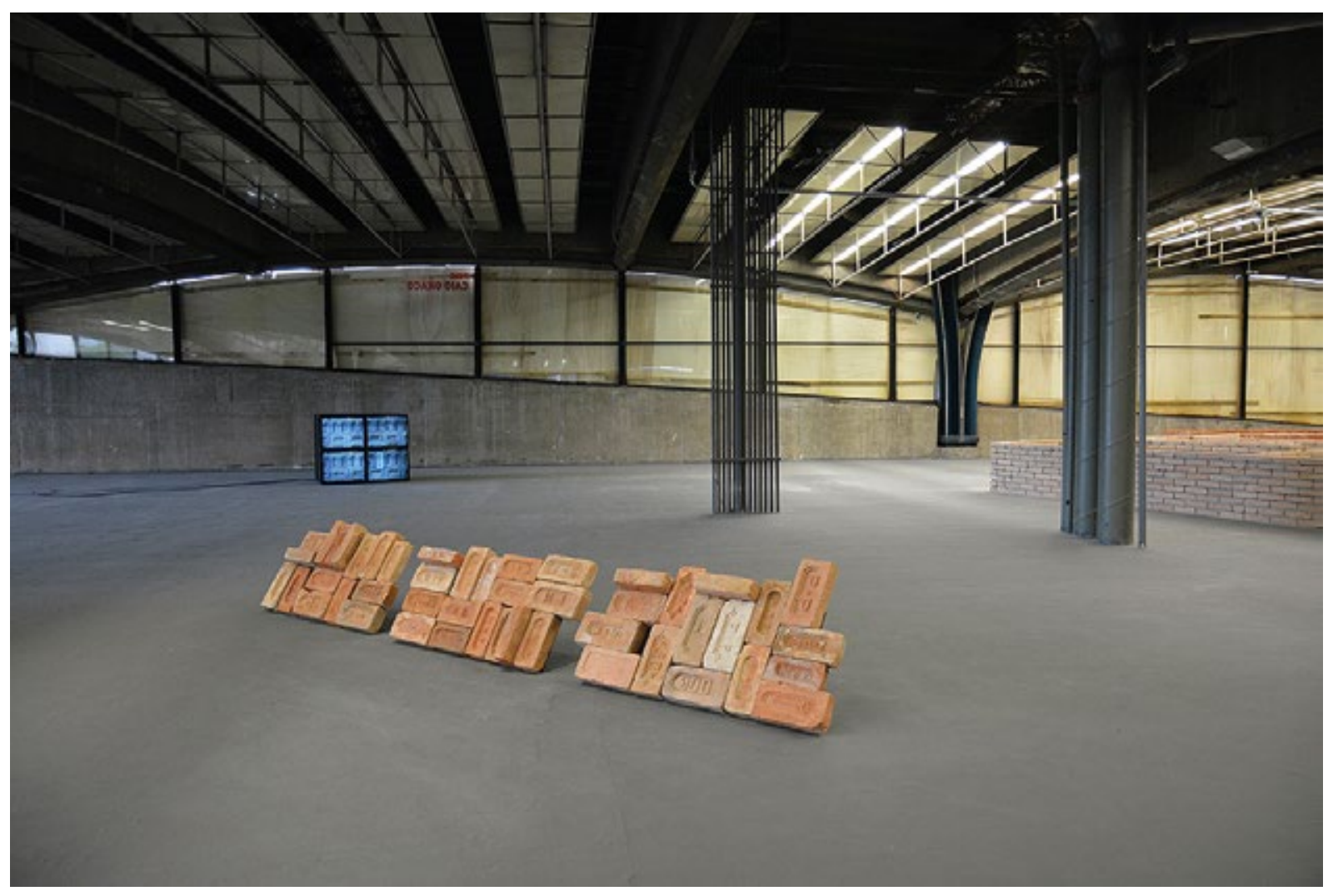


imanente [adição_multiplicação_ divisão_subtração_], 2014

instalação com 3700 tijolos: planta de casa mínima do sistema BNH (37 m²), planta de casa mínima do programa Minha Casa Minha Vida (37 m²)

Vista da exposição no Piso Caio Graco, Centro Cultural São Paulo

52 | 53 


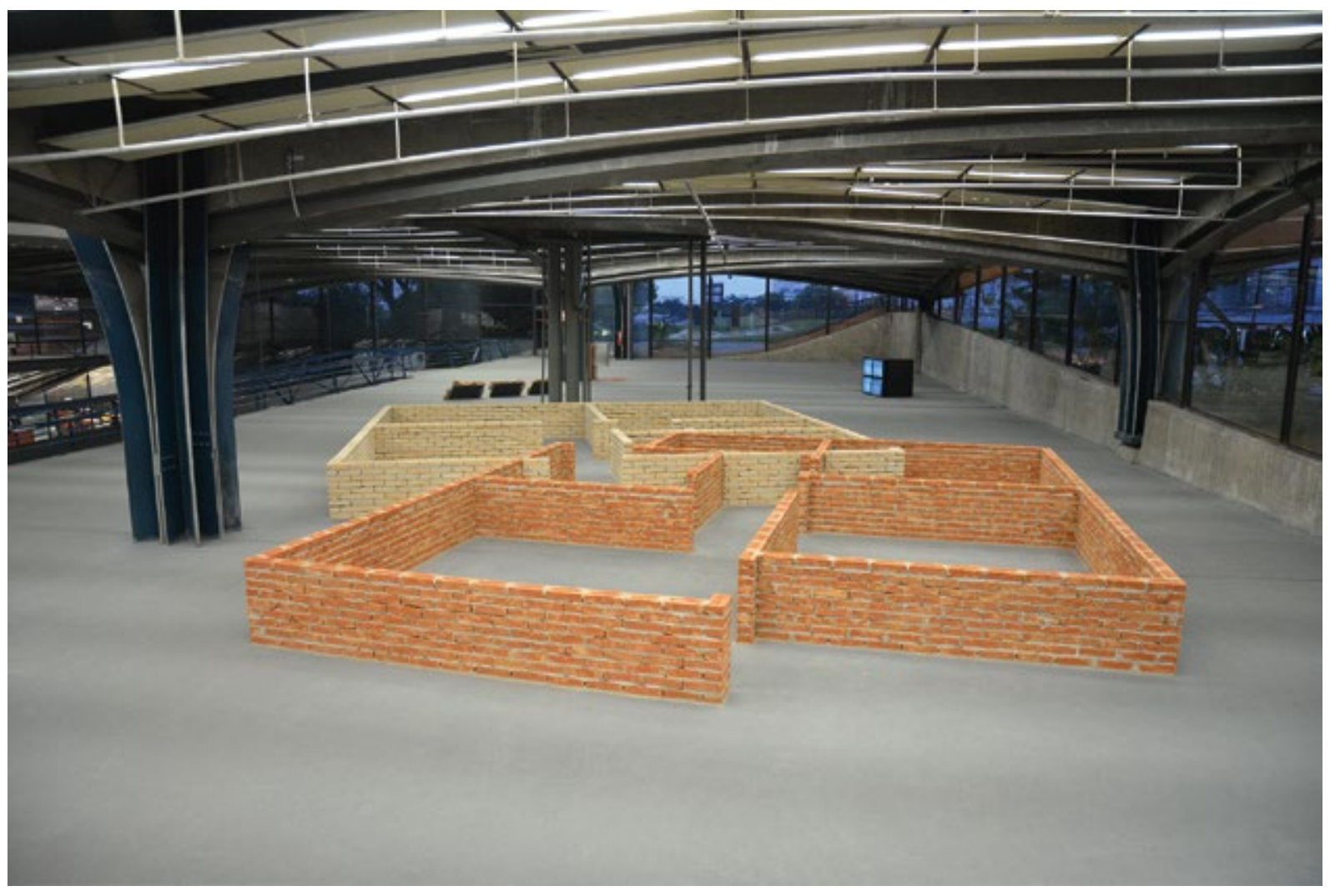


imanente [adição_multiplicação_

divisão_subtração_], 2014

detalhe da instalação com os tijolos

imanentes

$54 \mid 55$ 


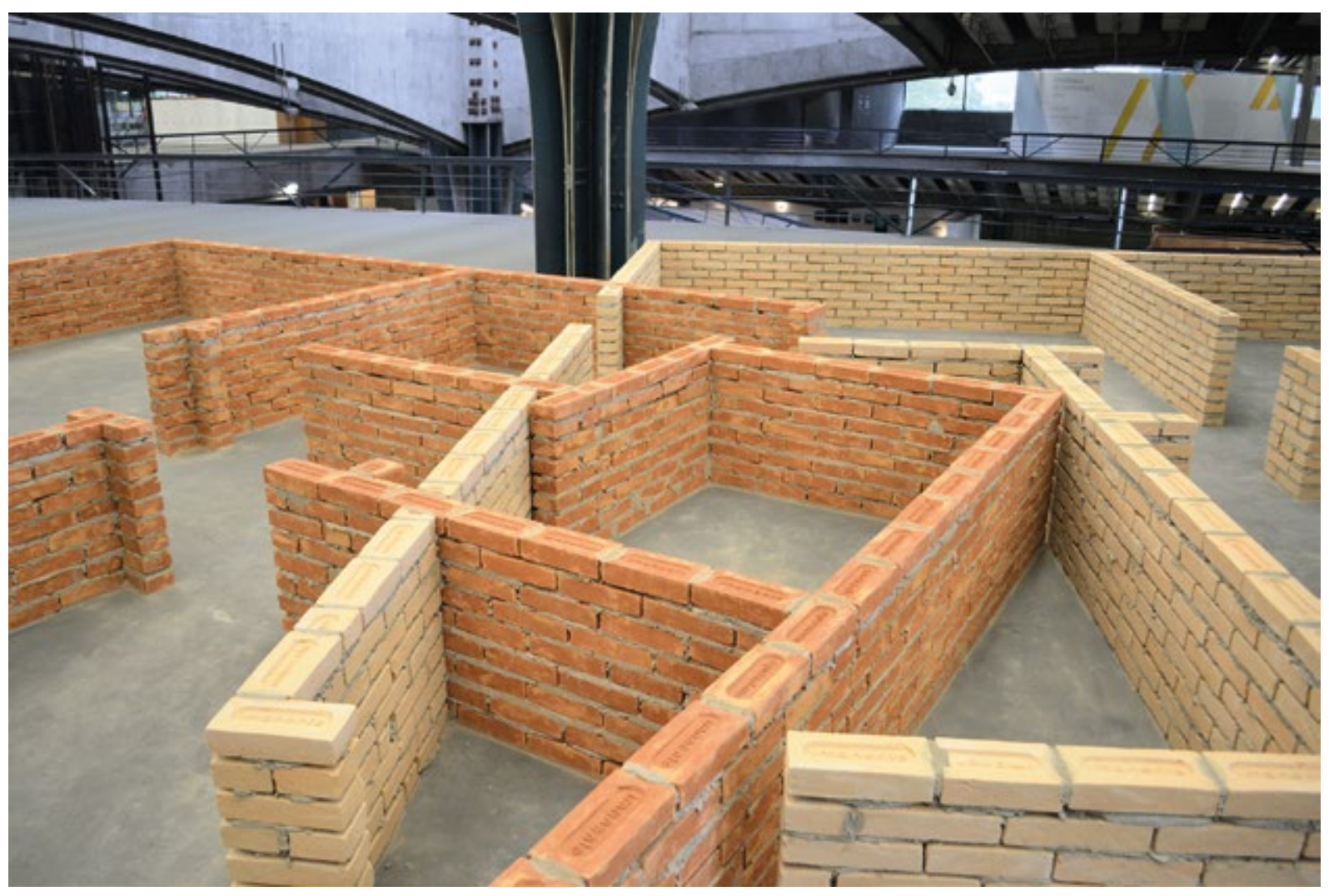




